\title{
'THE FLOWER GARDEN
}

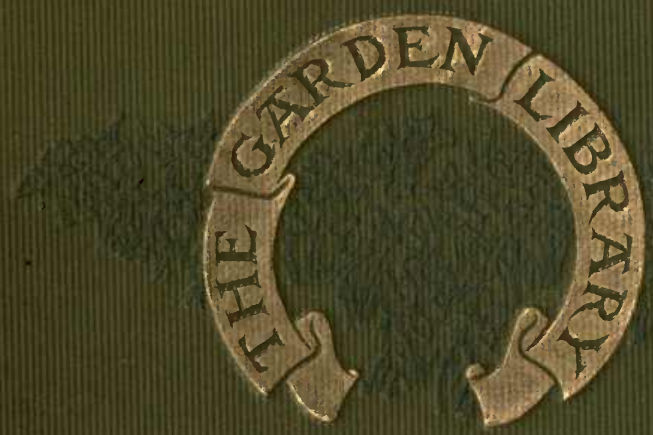




\section{BEABHS ROCM}

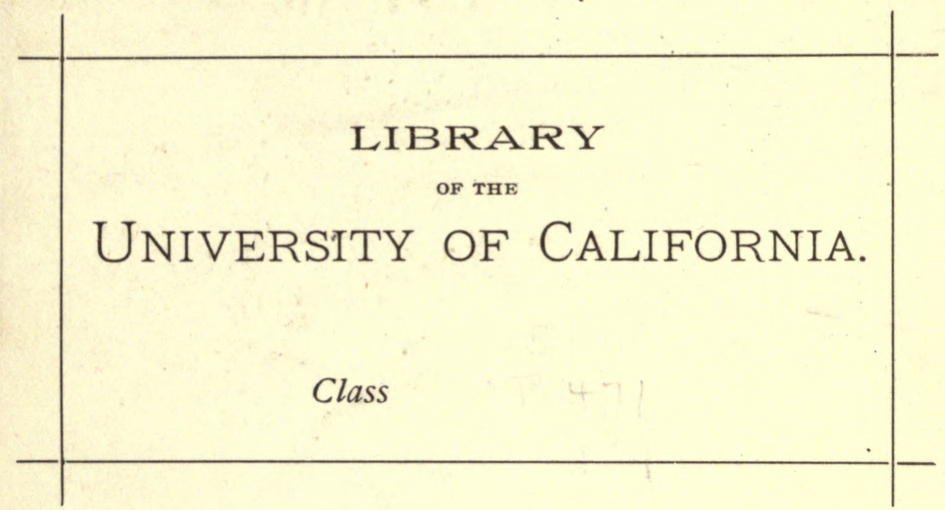








$$
-
$$




\section{THE GARDEN LIBRARY}

Roses and How to Grow Them

By MaNy Experts

Ferns and How to Grow Them

By G. A. Woorson

Lawns and How to Make Them

By LEONARD BARRON

Daffodils-Narcissus and How to Grow Them By A. M. KIRBY

Water-Lilies and How to Grow Them

By H. S. Conard and Henri Hus

Orchard and Fruit Garden

By E. P. Powell

The Vegetable Garden

By IdA D. BenNetT 


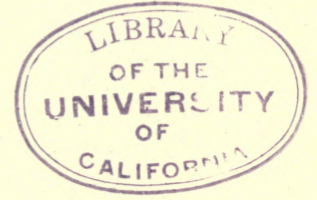




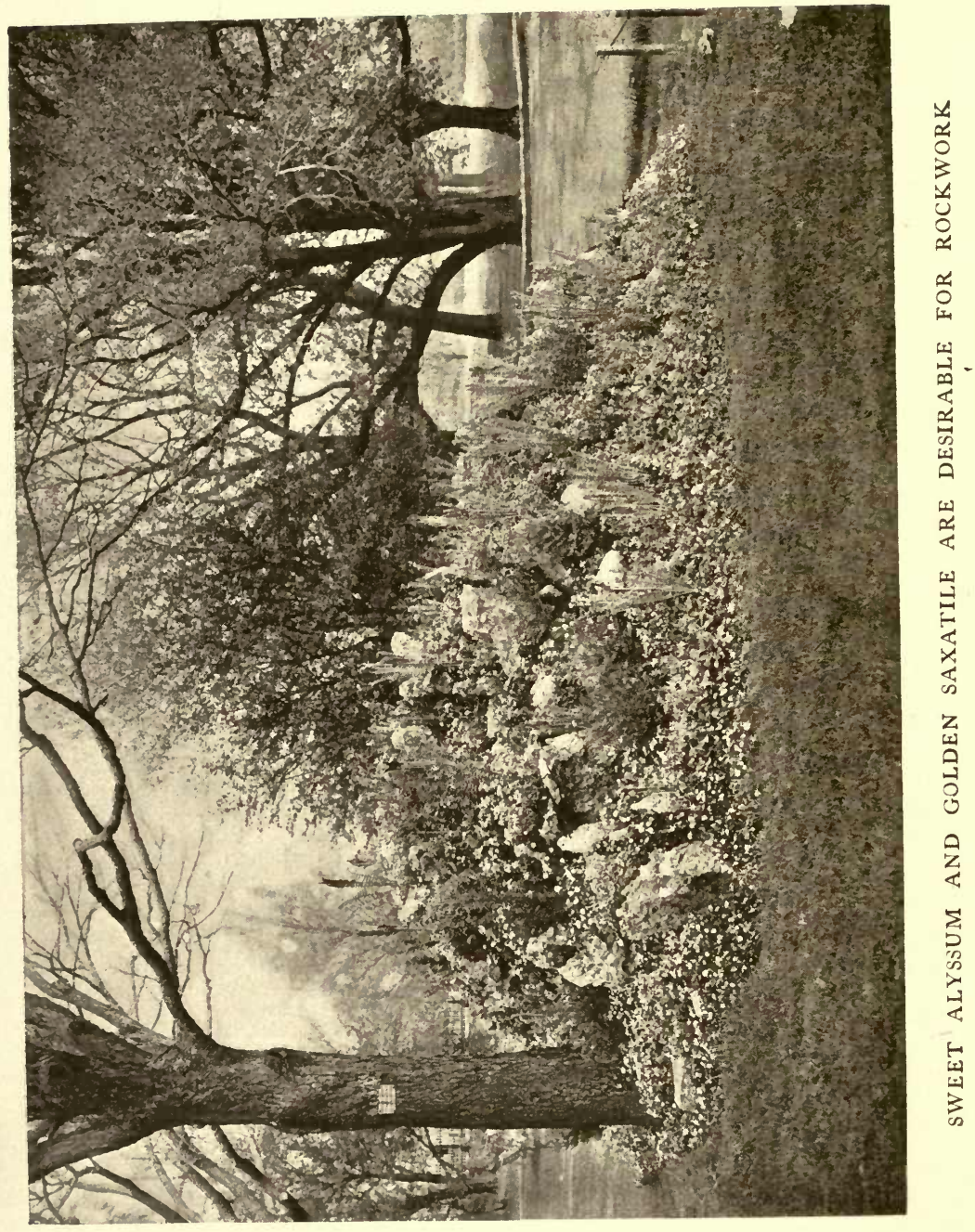




\title{
The Flower Garden
}

A MANUAL FOR

THE AMATEUR GARDENER

\author{
By \\ IDA D. BENNETT \\ ILLUSTRATED
}
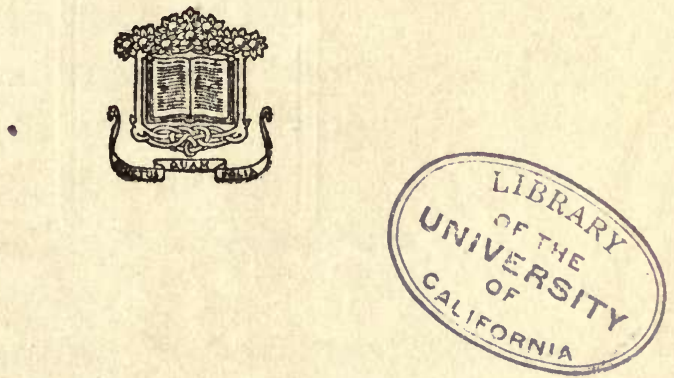

NEW YORK

DOUBLEDAY, PAGE \& COMPANY I 909 
$5 B 405$

34

1909

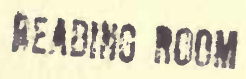

Copyrigbt, 1903, by

MCCLURE, PHILLIPS \& CO 


\section{CONTENTS}

CHAPTER

PAGE

I. The Location and Arrangement of the Garden.

II. SoIls

III. FERTILISERS •

IV. The Hotbed, Cold-Frame and SAND-Box .

V. Purchasing of Seeds

VI. Starting Seeds in Flats • • 48

VII. Transplanting and Repotting • 53 VIII. House-Plants from Seeds • 62

IX. Outside Window-Boxes • $\quad 88$

X. Various Annuals from Seed. 98

XI. Vines • • • • • $~ I 28$

XiI. Ornamental Foliage Plants from SEed • • . • • • I4I

XIII. Bulbous and Tuberous - Rooted

Plants . . . . 147

XIV. Aquatics . . . . . 165

XV. The Care of the Summer Rose-Bed 173

XVI. The Hardy Lily-Bed • • • I79 
CHAPTER

PAGE

XVII. The Care of Cannas, Caladiums,

Dahlias, and Other Bulbs

During Winter • . . I 85

XVIII. Hardy Shrubs and Plants for

Fall Planting . . . 196

XiX. Winter Protection . • . 203

XX. The Care of House-Plants in Winter • . . . . 208

XXI. Common and English Names of FlOWERS • • • . . 217

XXII. Blooming Season of Various

Trees, Shrubs, and Plants 234

XXIII. A Chapter of Odds and Ends 245 XXIV. A Chapter of Don'ts. • . 253

\section{INDEX}




\section{ILLUSTRATIONS}

Sweet Alyssum and Golden Saxatile are desirable for Rockwork . . Frontispiece

PAGE

Ornamental Grasses and Foliage Plants . 4 Height and Season of Bloom of the Different

Perennials . . . . 5

Plan for a Hardy Border . . . . 12

Plan for Rose-garden and Foliage-bed . . I3

Manure Water Is a Good Way to Apply Animal

Fertiliser . . . 28

When Plants Appear too Thickly in Rows

Transplant . • • . . 29

A Well-constructed Hotbed . . . 29

Starting Seeds in Flats . . . 52

Sifting Loam Through a Sieve . . $\quad$. 53

Repotting . . . . 60

When Two or Three Inches High-Transplant

Carnations into Pots . . . . 6I An Easily Made Carnation Support • • 6I Injured or Faded Leaves Should be Removed at once 
Outside Window-boxes

Boxes in which Scythes Are Packed Make very

Good Window-boxes

Hanging-baskets for Windows

96

Small Water Gardens

96

Cool, Moist Spots between Stones

97

Dusting with Sulphur

98

99

Spraying with Bordeaux Mixture

99

Sow Poppies in the Perennial Border among

the late Flowering Plants

I IO

A Dead Tree Draped with Vines

I I I

Furnish Support for Vines to Run on

I 28

Vine-covered Shed

128

Clematis Paniculata Blooms when most others Have Ceased

Shift into Larger Pots as Required ·
Should Bulb Outgrow Its Quarters Shift into

Pot Two Sizes Larger

Wild Water Flowers for Edging Lily-pond .

Water-lilies with Background of Bamboo and

Native Grasses

A Full-blown Cat-tail

Native Plants Edging a Natural Water Garden A Rose-covered Building

A Portion of the Grounds Protected by Shrubbery Is the Place for the Lily-bed . 
PAGE

Turn out Ball of Earth to Ascertain if Pot Is Filled with Roots . . . . $\quad$ Igo

Plants for Late Winter Blooming Should Be Brought into the House Before Fall . I9I 



\section{THE FLOWER GARDEN}




\section{Chapter ONE}

\section{The 江ocation and Arrangement of the Garden}

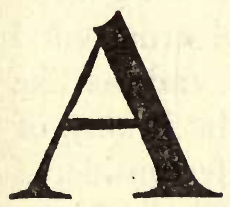

SOUTH slope is the ideal situation for a garden, since it insures good drainage and the greatest amount of sunlight. The garden should also be open to the east and west, if possible; that it may have the benefit of the morning and evening sun. Shelter on the north is desirable, as north winds are disastrous to Roses and tender perennials. Partial shelter on the west should be given in localities where the prevailing winds of winter are from that quarter.

The south side of a building, or even of a high fence, with trees and tall shrubs at a little distance to the west, is best; though any site that receives abundant sunshine through the morning and early afternoon may be made satisfactory by planting trees and shrubs on the north and west.

The garden should always be at the rear or side of the dwelling, never in front or along the street. The reasons for this are obvious. The garden proper 
is intended to furnish cut flowers, to provide a place of experiment with new varieties, and to grow hardy perennials which have certain seasons of bloom and cannot be depended upon, at all times, for ornamental effect. One should feel free to work there unobserved of the passer-by, and this is impossible in a garden close to the street.

Again, while the permanent garden is beautiful in itself, it is not suitable for the lawn and greatly mars the effect of the grounds. Beds of ornamental foliage plants-Cannas, Ricinus, Coleus, and the like -appropriately placed, add much to the beauty of a well-kept lawn, but should be carefully considered in relation to its size and the trees and shrubbery already there.

On a small city lawn not more than one such bed should be allowed. On a large lawn three will give a better effect than a great number, especially if care is taken to have them all visible from different points on the lawn and from the house, never isolating them by so placing that clumps of trees or shrubbery intervene, but using these rather as a background for the beds.

It is from the hammock that the amateur gardener will most enjoy the results of her labour. It is there she will find leisure to watch the growth of plants, to compare the effect of different varieties, to note where she may improve the vista by a different arrangement next year, to observe the effects of locality, 


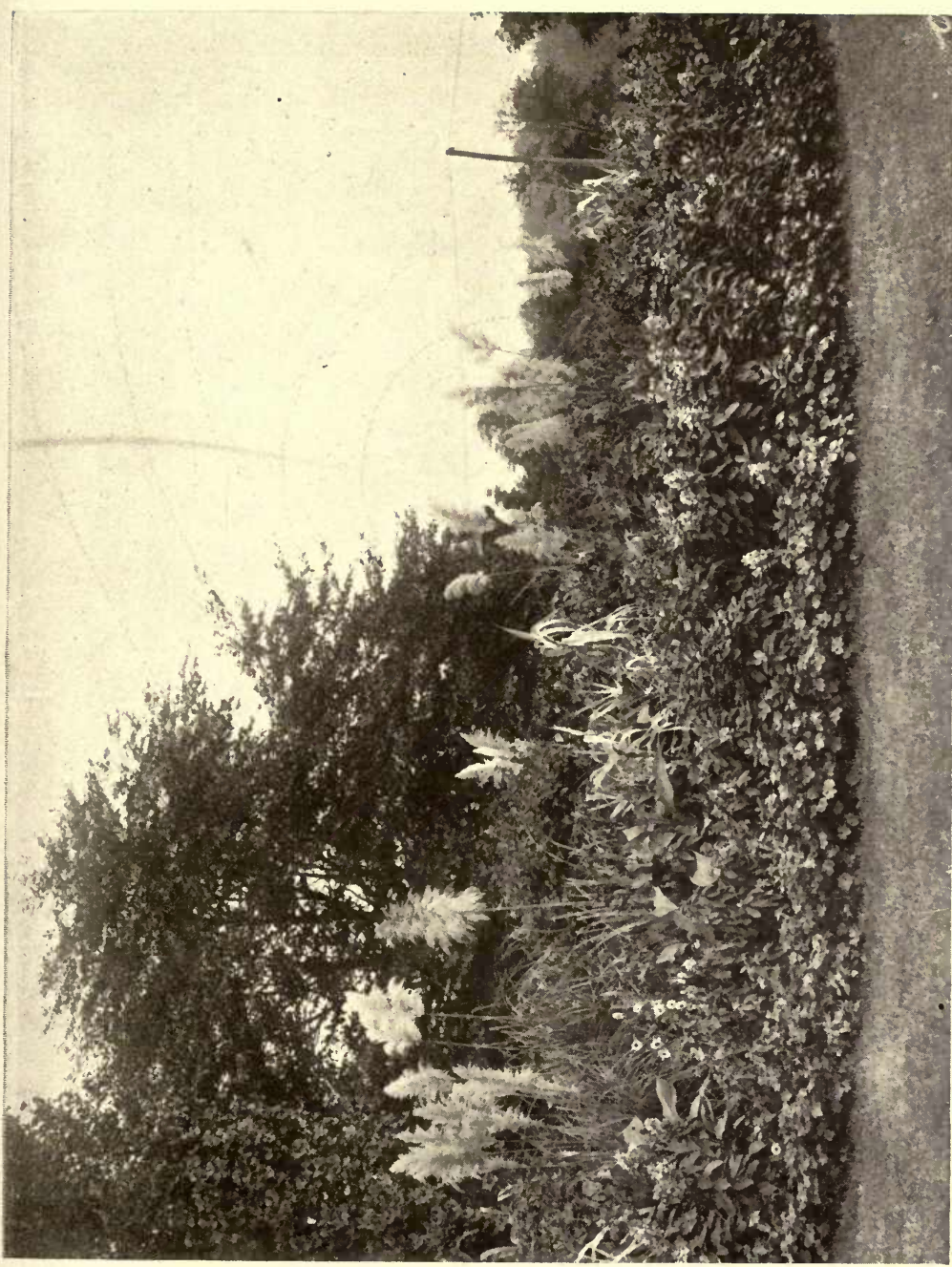

年 

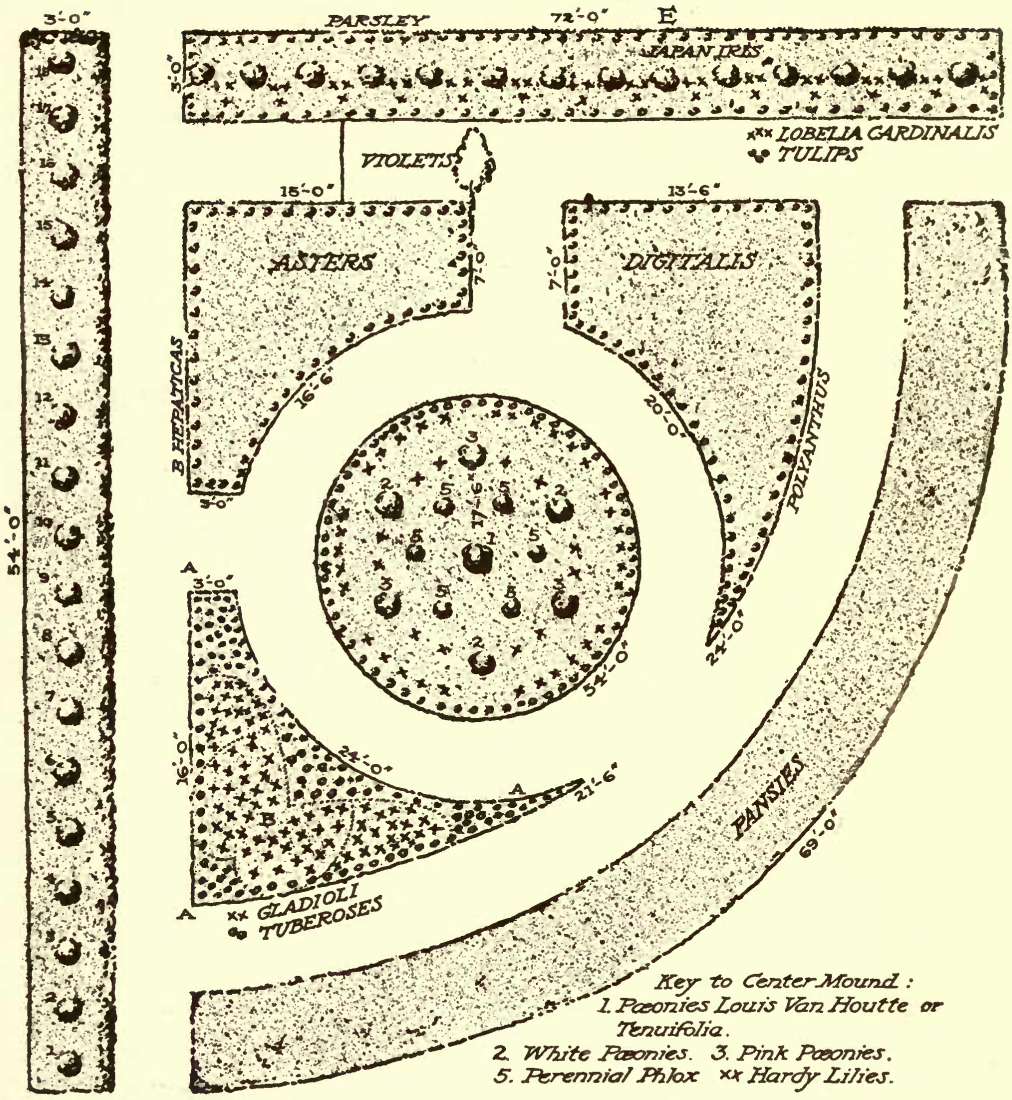

KEY TO PLATE I.

Giving the Height and Season of Bloom of the Different Perennials, Etc.

Outer Circle.

Pansies-all summer.

First Corner Bed.

A-Montbretias in corners, scarlet and orange, 2 to 3 feet-all summer.

$\mathrm{B}$-Gladioli in centre, in variety, 3 to 4 feetSeptember, October.

C-Tuberoses, 3 feet-August, September.

Border of blooming Oxalis, pink and white, 6 inches-all summer.

\section{Centre Bed or Mound.}

I-Dark red Peony, 2 feet-May.

2-White Peony, 2 feet-June.

3-Pink Peony, 2 feet-June.

4-Large flowered perennial Phlox-August, September, October. $\times$ A-Auratum Lily, 2 feet-August, September.

$\times$ B-Speciosum Album, 2 feet-August, September.

$\times \mathrm{C}-$ Melpomene, 2 feet-August, September.

$\times \mathrm{D}$-Auratum.

$\times$ E-Longiflorum, white, 2 feet-June.

$\times \mathrm{F}$-Rubrum, 2 feet-August.

$\times$ G-Candidum, white, 3 feet-June.

Border-Phlox Subulata.

\section{Rear Corner Beds.}

North Bed-Anemones, Whirlwind and Queen Charlotte, white and pink, 3 feet-September.

Border-Wood Anemones.

South Bed-Asters. 2 feet-September, October.

Border-Aurizula, 8 inches-Mav. 


\section{One] Zlocation and Arrangement}

of the afternoon and morning sun and all the peculiarities of plant growth that escape her when busy with trowel and watering-pot, so that the view from it should be first consideration.

A very good arrangement is to put a large bed of Ricinus on the most remote space of the lawn-four plants in the centre of a twelve-foot bed-surrounded with a row of Salvia splendens edged with Little Gem Sweet Alyssum. Nearer, an eight-foot bed of the large-flowered Cannas may be introduced and edged with Coleus or the second size of Caladiums, while a six-foot bed of ornamental grasses-Arundo Donax, Erianthus Ravennæ, Eulalia gracillima univittatawill make a satisfactory third. Such beds are rich in tropical effects and give more distinction to a lawn than any other class of plants.

Where there is an ample water-supply these beds may be elevated a few inches above the lawn to make them more conspicuous; but where the seasons are hot and dry and water must be carried it is better to set them slightly lower than the lawn, so that all the available moisture may be utilised. A few inches of margin must be allowed around the edges of beds on the lawn so that the mower may run close to the beds without injuring the plants, though even then it will be best to use the lawn-shears. Such beds call for carefully trimmed lawns. Unless the grass can be properly cared for, it is better to exclude flowers from this part of the grounds entirely, as it is time 
thrown away to plant flowers which will presently be hidden by tall grass and weeds. A neglected lawn involves an amount of labour in the semi-annual cleaning of spring and fall out of all proportion to the results, while a lawn well cut and raked is more easily cared for with each recurring year, the grass growing clean and straight, and the rake and mower passing freely and easily through it.

The scheme for a permanent garden must be decided by the size and shape of the plot of ground at command, an irregular plot sometimes lending itself to more graceful arrangement than a symmetrical one. The operation of laying out the beds will be the same, whatever the shape. Having decided the boundaries of the garden it will be best to mark the outlines by a cord attached to pegs driven into the ground. The sod should then be removed from the entire area by cutting just below the crown of the grass. Desirable arrangements of beds are shown in accompanying illustrations. Two and one-half or three feet should first be allowed for walks. The beds may be placed to advantage by finding the centre of the plot and driving there a stake to which a cord is loosely attached. Mark off on this cord half the diameter of the bed desired, for centre of plot, four, five or six feet -fasten to the cord at this point a sharp stick and describe the circle on the ground. In this way the garden walks may be outlined and the inner and outer circles of the round beds. The oval beds must be 


\section{One] Zlocation and Arrangement 7}

measured off and defined by stakes driven into the ground. The width of the beds should be not more than can be easily reached across for weeding and cultivating. Where the soil has not been previously cultivated it must be spaded at least two feet deep, and thoroughly pulverised. All roots and stones should be removed. If the soil is clayey or gravelly it will be best to remove it entirely and to fill in with soil better adapted to the growth of flowers. Or the surface may be removed for several inches and laid aside. Then the poorer subsoil should be dug out and removed and the surface-soil replaced in the bottom of the bed with a liberal quantity of old, wellrotted manure. The bed should then be filled to its original level with leaf-mould or muck. If all the original soil is to be retained, remove the top-soil for top-dressing. Spade the manure into the subsoil and replace the surface-soil. In ground which has not been cultivated this surface-soil is rich in humus or leaf-mould, which furnishes food in its most available form for the young plant, and should, therefore, be left where the plant can use it and not be turned under as is usually done. Nature never turns the soil upside down; nor will the wise gardener, except when a richer and better soil is to be added or when it is necessary to work in manure.

In making beds that have been worked before and need no enriching, excellent results may be secured by pushing a long spade into the ground the 
whole length of its blade and twisting it around. This breaks up and mellows the ground more effectually than turning it over, while it leaves the good soil on top where the young plant-roots can get it. Later, when the plant grows sturdier and stretches out its roots in search of food, the manure-enriched earth in the bottom of the bed will attract and draw them down into its cool, moist depths, away from the heat and drought of the surface. But the young plants must have mellow, nourishing soil from the start, or they will perish before they reach this store-house provided for the mature plant.

Never prepare a garden by turning under the sod. I am well aware that this, together with turning under the surface-soil, will be the method of the average man who has had some experience of farming, but the flower-grower cannot always follow farming methods with safety.

After spading the beds it will be well to inclose them with some such permanent material as brick, cement curbing, or narrow boards. Four-inch siding set in the ground an inch or more, and held in place on each side by pegs of wood (old waggon spokes, which can usually be found at the blacksmith's, are excellent for this), make the cheapest and most quickly constructed inclosure, and may be quite covered with such border-plants as Dusty-miller or Phlox subulata. The boards may be given a coat of dullgreen paint or shingle-stain before being put in place. 


\section{One] 江ocation and Arrangement 9}

The permanent garden beds should have some such protection, as it greatly lessens the work of caring for them. Sod borders are very attractive, but involve an amount of care altogether out of proportion to the effect, as they must be kept closely shaved and the constantly encroaching roots of the plants must be as constantly curbed. This is also the case with grass walks, attractive to look at, but a supreme nuisance to the gardener. Walks of gravel, cinders or coalashes are preferable, and should be dug deep enough to smother out all weeds in the soil. If coal-ashes are used the paths should be nearly filled, the roughest part raked off and the surface gone over with a heavy roller. If left unrolled, however, the surface will be found firm and hard after the first heavy rain. Very good and inexpensive walks are obtained in this manner. Walks, of whatever kind, should never be hoed, and the weeds must be removed from them by hand. Hardness and smoothness are the requisites of a good walk. It is well to avoid self-sowing flowers like Sweet Alyssum, or Petunias, near the inside walks, as they come up by thousands in the spring and can only be removed by salting, scalding or uprooting.

The beds should be well above the surface of the walks, especially those containing hardy perennials like Peonies and Lilies. In the case of most plants, water standing around their roots in winter is absolutely fatal.

The location of the beds and their consequent 
moisture and sunshine must determine the flowers to occupy them. If you are fortunate enough to have a corner low, damp and shaded in the afternoon, that is the place to set out the beautiful Japanese Iris, Cypripedium acaule and other moisture-loving plants, while the Gladiolus may be given a prominent place in full sunshine. Asters and other flowers that do not bloom until fall should have a less conspicuous place; they are so showy that they will not fail to attract attention, wherever they may be planted. Pansies and other low-growing plants should be set out in the bed next the lawn. The general effect is finer when only one kind of flower is grown in a bed, but when two or more varieties of flowers, harmonising in colour, are grown together, the tallest must be placed in the centre and the others grouped according to height. Various plants may be used as edgings, due consideration being given to the plants which are to fill the beds.

A mass of one kind and colour is more effective than a mixed bed. The beginner will find that the percentage of success is greater in growing a large number of one kind, all requiring the same conditions of soil, moisture and sunlight, than in trying to force plants of widely different habits to grow under the same conditions. Hardy perennials, however, not many of which deserve an entire bed, do very well with several varieties in the same long bed or border, and may be so grouped as to give a succession of 


\section{One] ILocation and Arrangement in}

bloom throughout the season. A raised bed of Peonies interspersed with the new, large-blooming Phlox and bordered with Japan Lilies will give a succession of flowers from May to October; or a long bed of Hollyhocks, or Hibiscus with a row of largeflowered Phlox in front and edged with dwarf Phlox Drummondii will give months of lovely bloom. This last combination also makes a serviceable screen between the vegetable garden and the lawn, or to hide a rear fence.

In arranging parti-coloured beds of flowers, due attention must be paid to the harmonising of tints. Do not combine magenta and scarlet, or purple and blue. Separate them by the interposition of whitethe most valuable colour in the garden, as it not only harmonises all colours but wonderfully enhances their brilliancy. White with scarlet, with blue, or with yellow is always good. Lavender and heliotrope are lovely with nearly all shades of scarlet, rose and pink. Blue flowers planted in the rear of the garden increase its apparent size, while white, bright yellow and scarlet, by bringing the background nearer, decrease it. Monkshood and the tall blue Larkspur are excellent for rear beds.

The accompanying diagrams will be of assistance in planning the garden - not so much in supplying plans to be followed literally as in suggesting other plans and variations, while giving practical information as to number of plants required, their distance apart and 
the like. Soil and other details will be treated elsewhere.

In planning a shrubbery (see Plate II.) it is neither necessary nor desirable to use boards or other curbing for the beds, but the turf should be kept neatly trimmed and cut. A plot 60 by 40 feet or more, inclosing a considerable area of turf, gives room for rustic seats, a stationary hammock, and a tree or two. The circle in the border greatly increases the accommodation for plants and furnishes an ideal spot for Lilies. The lily-pond in the centre will be discussed at length in the chapter devoted to aquatic plants.

The rather complicated design in Plate III. is intended for a rose-garden or for foliage-beds on a large lawn. It is not at all difficult to construct, and a little practice with paper and pencil will remove any apparent obstacle. If you will draw, on a scale of one inch to a foot with a compass a succession of circles of six, eight and a half, twelve and a half, fifteen and nineteen inches, respectively, the foundation of the plan will be laid. Now, divide the fourth circle into fifths and draw a half circle $4 \frac{1}{2}$ by $\mathrm{I}_{4}$ feet or inches on the circle of each fifth by placing the point of the compass midway between the fourth and third circle. This will leave a crescent-shaped bed. Mark off from each side of these half circles or crescents, on the space between the third and fourth circle, two and one-half feet for paths. Making the lines parallel with the crescents, the remaining spaces will 


\section{E}

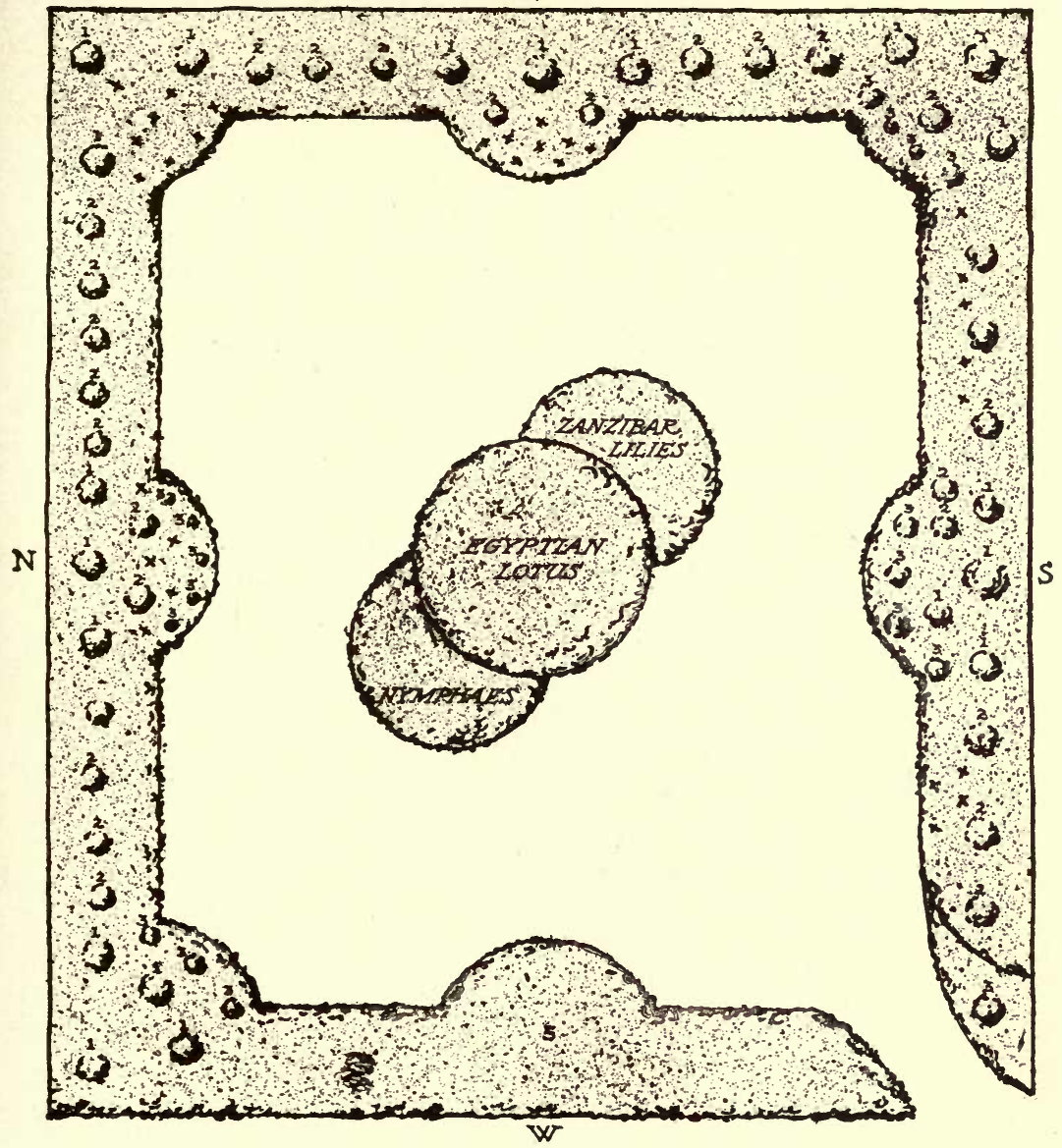

KEY TO HARDY BORDER. PLATE II.
Name of Plant.
Color.
Height.
Feet, Inches.
Season of Bloom.

I. Hypericum.

Yellow............ I

6.......All summer.

2. Deutzia Gracilis . .................. White .......... I

3. Lychnis Roseum .............. Pink .......... I

4. Spiræa Filipendula............... White...........

5. Platycodon $\ldots \ldots \ldots \ldots \ldots \ldots \ldots$. Blue............2

6. Anemone Whirlwind ................ White...........

7. Spiræa Anthony Waterer.......... Crimson .......2 to 4

8. White Foxglove ............... White. ....... 3

9. Scarlet Lychnis.................. Scarlet..........

ro. White Foxglove $\ldots . . \ldots \ldots \ldots \ldots \ldots$ White..............

II. Lychnis Splendens ...............Red. ......... 3

I2. White Veronica ................. White $\ldots \ldots \ldots \ldots . .2$

13. Blue Veronica................. Blue .........

14. Spiræa Van Houttei ............. White............

15. Monkshood Fischeri .............. Pale Blue .. ....4

I6. Hollyhocks in Var. ......................... to 5

17. Monkshood, Uncinatum........... Dark Blue.......4

18. Bocconia................................ to 6
$8 \ldots . .$. May, June.
8 ......All summer.
o.......May, June.
o.......All summer.
o.......September, October.
o.... May; sometimes all summer.
o.......All summer.
o......All summer.
9.......All summer.
o...... June, July.
o...... August, September.
o...... July, August.
o......May, June.
o...... September, October.
o..... Summer, fall.
o..... June, August.
x. Tall Shrubs.
2. Low Shrubs. 


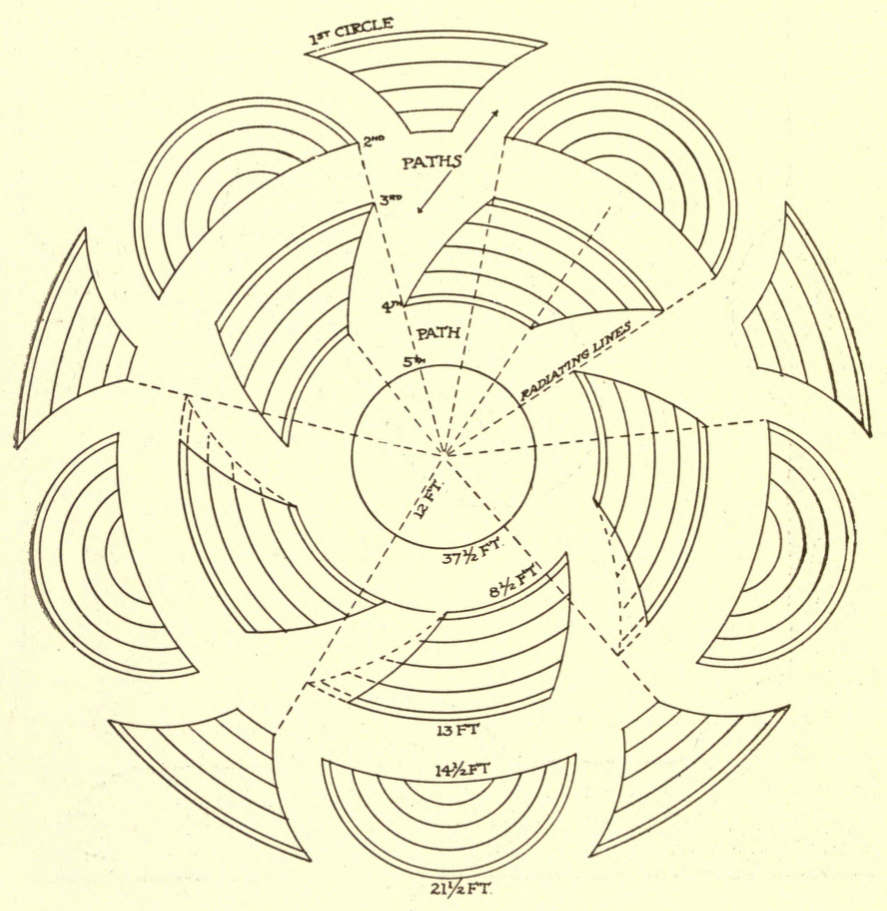

PLATE III.

Plan for Rose-garden and Foliage-bed. 


\section{IL ocation and Arrangement}

form triangular beds, that for convenience may be called the third or outer row of beds.

Now if radiating lines be drawn from the corners of the crescents to the centre of the plan the point where they cross the third circle will be the upper corners of the first row of beds-the lower corners being formed by the point where the radii from the centre and left corners of the crescents cross the second circle; the third and second circles forming the upper and lower sides; the ends being formed by curved lines drawn from the upper to the lower corners. Or, having completed the row of five crescents and five triangular beds, mark off with pole or ruler radiating lines from the corners and centre of each crescent to the centre of plan; the point where these radii from the circle of crescents cross the third circle will be the upper corner of the first row of beds; the lower corners being formed by the radii from the centre and left-hand corner of crescents; the ends being formed by curved concave lines from upper to lower corner-the intervening spaces forming paths.

\section{For Laying Out the Beds}

TSE a long pole with a sharp stake passed through a hole at one end and fastened with a nail driven through it horizontally, so that it can turn easily, with a number of holes for pegs at the required distances-six, eight and one-half, twelve and one- 
half, fifteen and nineteen feet. Drive the movable stake firmly into the ground, and do not remove until the work is finished. Slip the sharp marking peg into the hole, which it should fit closely, and mark out the circles. For the half circles, or crescents, a nine-foot stick laid straight across the edge of fourth circle will give an approximate fifth, the loss in the curve about equalling the fractional loss caused by multiplying by three alone. Drive a peg with a stick or string attached into the path a foot inside the third line and mark the circles on it; mark the paths by lengthening the stick or string two and a half feet and drawing sections of circles on each side of the half circles from the fourth to the fifth circles. Now bring the end of the long pole to the left corner of half circle and mark the radiating lines and half lines to the centre, and mark off the first row of beds as you did on paper. In this way almost any form of flowerbed may be laid out. The following diagrams for foliage-beds on the lawn will be helpful.

\section{For a Twelve-foot Foliage-bed}

NE Ricinus in centre; three Ricini four feet from first, an equal distance apart-or about eight feet. Alternate with these three clumps of tall-growing Cannas: Surround with a row of scarlet Salvias, set one foot from edge of bed and twenty inches apart. Edge with Little Gem Sweet Alyssum. 


\section{One] Zlocation and Arrangement i5}

\section{Another Twelve-foot Bed}

NE Ricinus in centre, surrounded at three feet distance by six of the largest sized Caladiums three feet apart. The third row, three feet outside, to be composed of low-growing Cannas-Queen Charlotte, Chicago, Florence Vaughan, or Papaeighteen inches apart. Edge with dwarf Nasturtiums.

\section{Nine-foot Bed}

NE Ricinus trimmed in umbrella form - that is, the lower leaves removed so that the upper may serve as a shade for the Cannas. First row, six Allemannia Cannas; second row, twelve inches outside, twelve Burbank Cannas, fourteen inches apart; third row, twenty-five Italia Cannas, fourteen inches apart. Edge with Coleus, set fifteen inches apart.

\section{Nine-foot Bed}

CENTRE three discolour Cannas, grouped in the 4 corner. First row, twelve Black Beauty Cannas, eighteen inches apart; second row, eighteen inches outside, twelve large Caladiums, twenty-seven inches apart.

\section{Twelve-foot Bed}

THREE Ricini in group, equal distance apart.

1 First row, three feet out, scarlet Salvias, twenty inches apart; second row, twelve inches out, white- 
flowered Vincas, twelve inches apart. Edge with scarlet Phlox Drummondii or blue Tom Thumb Ageratum, six inches apart.

\section{Nine-foot Bed of Ornamental Grasses}

ARGE clump of Arundo Donax in centre. First 1 row, three feet out, three Erianthus Ravennæ, six feet apart; second row, twelve Eulalia gracillima univittata, two feet apart.

\section{Eight-foot Bed}

A LARGE clump of Setaria magna in the centre. A First row, Coix lachryma, eighteen inches apart; second row, twenty inches out, Pennisetum Ruppellianum, eighteen inches apart.

I cannot too highly recommend the planting of ornamental grasses on the lawn. They are extensively used in parks and in other public grounds, but not nearly so extensively as they should be on private grounds. Many of them are perfectly hardy, and once established grow in beauty from year to year; others in the Northern States may be easily wintered in the cellar, while still others may be cheaply and easily raised from seed each year. 


\section{Chapter $T W O$ \\ Soúls}

T

$\mathrm{N}$ every garden the matter of soil is of first importance. In case of an outdoor garden the existing conditions will largely determine the class of plants to be grown.

A good loam-that is a non-coherent mixture of clay and sand with a proportion of such decayed vegetable matter as leaves and the fibrous roots of grasses-is the best garden soil, being what is termed warm and early. Soil containing a good proportion of sand is warm, while a preponderance of clay makes what is known as cold or wet soil.

If there is good drainage, cold soil can be rendered lighter, sandier and more friable by the liberal application of manure, which in two or three years will quite change its character. But this is a long time to wait, and to get quick results it will be necessary, after laying out the garden and outlining the beds, to remove the earth to a depth of twenty inches or more, filling in with soil suitable for the class of plants to be grown in each bed. In the beds intended for Roses, however, the clay may be left, as Roses require this soil. Where 
it is not present it should be supplied and added to each year, as the heavy manuring which Roses require constantly reduces the relative proportion of clay. For the Pansy bed nothing better than leaf-mould from the woods can be procured. For this bed remove six or eight inches of earth, spade in a good supply of old, well-rotted manure from the cow-stable, top-dress with several inches of leaf-mould. You will have a bed that will give magnificent Pansies and few weeds. For the Salvia, Canna, Ricinus, Caladium and other strong-growing plants no soil is better than the muck or peat of swamps-soil composed of partly carbonised vegetable matter decomposed by the action of water. Leaf-mould consists of vegetable matter which has decayed without being submerged, and it usually contains a liberal quantity of sharp, white sand, to which it owes its friable, non-adhesive character. Leaf-mould is commonly found around decayed stumps and in hollow places in the woods, where the leaves have drifted and decayed. It is ready for immediate use. Muck or peat, however, which is found in bogs and swamps, is unfit for garden use when freshly dug-except for aquatic plants-being tough and fibrous. It should therefore be dug during the summer, thrown in a heap and left for the winter frost to rot and render tractable. For immediate use the best method is to place it in a deep hole in the bed and cover with several inches of loam, or old muck. If this is kept worked or mulched to exclude air and 
retain the moisture in the muck, excellent results may be secured. The bed may also be partly filled with muck and covered with loam, the whole object being to prevent the muck drying out into hard lumps, as it will, when green, on exposure to sun and air. The following spring the loam may be spaded into the muck, giving a warm, mellow, exceedingly rich soil that will grow anything. The importance of starting out with good soil cannot be too strongly urged. It seems at first sight to call for a considerable expenditure of time and money-especially where the earth must be purchased and the labour paid for-but in the long run it is a decided saving.

With unsuitable soil there must be many failures, resulting in loss of both plants and seeds, and this in itself is no small expense. The labour of caring for such a garden is many times greater, for the topdressing of manure required produces an incessant crop of weeds, which must be removed, not once, but many times during the summer, while beds filled with leaf-mould or muck need but one or two weedings. The weeds which grow naturally in these soils do not flourish in the open ground. A few Smartweeds and Nettles may be expected in the one case, and Violets and Spring-beauties in the other. In the manured garden soil an endless procession of Purslane, Malice, Ragweed and the like must be constantly watched for. The presence of clay and gravel in the soil always renders it hard and given to caking, necessitating fre- 
quent cultivation; while muck-beds, after the preliminary spading in the spring, remain free and mellow throughout the season.

Replacing soil presents more difficulties to city dwellers than to those living in the country, or in small towns, but, as there are in the vicinity of most of our cities rich peat lands, it ought not to be difficult to obtain one or two loads of this useful material. Near the small towns are always to be found farmers who own or live near marsh-land, and can supply muck, especially where they have been ditching. A good waggon-load may be had at prices ranging from fifty cents to two dollars, according to the distance to be hauled. The cost in the city would, of course, be much greater.

It is well for the amateur gardener to learn early in her experience to keep her eyes open to all things pertaining to the success of the garden. When driving, note the marsh-lands easily accessible from the highway, especially where they have been ditched or partially reclaimed, and interview the owner or tenant. In the dull season on the farm the owner of such soil may be glad to earn an extra dollar or two, and it may also be suggested to the farmers' boys, who have marsh-and wood-lands, that they may earn pocket-money by calling on people known to be cultivating flowers or building new homes, to solicit their orders. Many people who grow flowers do not know where to apply for earth, and an advertisement in a 
local paper would, doubtless, prove advantageous to customer and purveyor. On hillsides along the road, and places which the rain has washed, one may gather quantities of pure white or grey sand for potting. Yellow sand is not suitable for such use, as it contains much clay and cakes badly after watering, while the white or grey sand remains fine and loose.

Leaf-mould is not so readily procurable, as it must be gathered from suitable patches through the woods, and the farmers do not like to bother with it. Besides, they are likely to dig up much undesirable under-soil. It is better to go one's self for this. A still better way is to make your own leaf-mould. Thus: when sod is removed from the ground for any purpose, shake out the fine soil that adheres to it for future use; or slice off the fine roots with a sharp knife just below the crown of the grass. This is known as fibrous loam, and, in combination with leaf-mould, old manure and fine, sharp sand, makes the very finest potting soil. Throw the tops of the sods in a heap in some out-ofthe-way corner and add the rakings of the yard in fall and spring, all weeds pulled during the summer, all vegetable refuse, potato-parings, apple-peelings, corn-husks, and berry-hulls-anything that has vegetable matter and will decay. All dish-water and slops that are not needed on the garden may be thrown on the pile, which should be turned over occasionally during the winter. By the following spring you will have the finest kind of leaf-mould. Not all of the pile 
will have decayed, but along the sides and underneath it will be found ready for use. Add to it every bit of available vegetable matter during the year, including the annual flowers pulled up after their season of bloom, the tops of such root-plants as Cannas, Caladiums, Gladioli, etc., and you will soon have a supply quite adequate to the needs of an ordinary garden. Where there are water-works the hose may be turned on frequently to hasten decomposition. If it is impossible to replace all poor soil in the garden with better, by the addition of leaf-mould and manure, much may be accomplished in the way of building up the old and rendering it suitable.

If the plot to be used can be ploughed up, well manured, and sown to clover, the clover turned under in the fall, a good top-dressing of manure given, and the whole turned again in the spring, the soil should be in good garden condition.

Where the soil is a good, warm loam the addititon of fertilisers will always give excellent results, though there is the disadvantage of weeds and extra cultivation to consider. The first cost of suitable earth is great, but it pays in the end in the saving of fertilisers, labour, expensive seeds and flowers. 


\section{Chapter THREE Jertillígers}

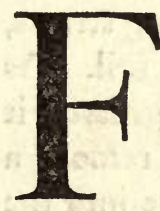

ERTILISERS in the form of animal manures, chemicals or vegetable matter come next in importance to a good soil. Horse, cow, sheep, and poultry droppings are the cheapest and most direct in results. Of the four, cow manure is probably the best for the majority of plants, especially Pansies, Iris, Violets, Ferns and others which love a cool soil. Cow manure is known as a cool manure, and is suitable for a warm or sandy soil. Horse manure, which is more heating, especially when from young stock, is better on cold or clayey soil, as it has the effect of breaking up the adhesiveness of the clay and promoting the formation of sand. Hen manure is very warm and is therefore most suitable for cold soils. Sheep manure is especially desirable for Roses and house-plants, about one part manure to six of earth being the proportion.

Good results may be obtained by the use of any or all of these, if in the proper condition and judiciously 
applied. Manure is in proper condition when it has passed completely through the heating or fermenting stage. Fresh manure should never be placed where it, or the water that leaches from it, can possibly come in contact wth the plants; manure should be six months or, better still, a year old before being used. Old and well-rotted manure has much the appearance of rich, black earth, and is readily assimilated by the plants. It should be fine and free from such rough litter as corn-stalks, cobs, and long straws, and should be thoroughly mixed with the soil. As manure is full of the seeds of weeds and grasses, it is better, when applying it in the spring, to remove a portion of the top-soil and work the manure into the subsoil by spading, and then to return the top-soil. This will prevent their germination and save a great deal of weeding during the summer.

Manure that retains its original form is too fresh to use and should be thrown in a heap and frequently forked over to hasten decomposition. It will be fit by another season, but older stuff must be procured for present use. Where there is room it is a wise provision to keep a pile of manure from year to year, in order to avoid the inconvenience of looking for it when you need it. No better expenditure can be made by the gardener than in purchasing several loads of old manure, when it is discovered in some neighbouring barn-yard. If one has no supply and must purchase, the matter should be attended to in the fall 
at latest, to allow ample time for saving it. Farmers usually draw the manure on the land as it accumulates, so that it is difficult to obtain in the spring.

Ashes contain a certain amount of phosphates, which tend to sweeten the soil. They are also beneficial in increasing the strength or stiffness of the stalks, and for this reason are valuable for Aster and Gladiolus beds; they should never be mixed with manure, as is frequently done, but should be strewn over the surface of the soil after the other fertilisers are worked in. Ashes mixed with manure release the ammonia of the latter, depriving it of one of its most valuable properties. Ammonia itself is not a fertiliser but a stimulant, creating in the plant a desire for the food stored up in the manure-in other words, an appetiser. Plants, like people, will not eat unless they have an appetite, and manure mixed with ashes is poorer and much less valuable in every way to the farmer and gardener. Soot is another excellent chemical fertiliser, adding much to the richness of colour in both flower and foliage. Apply either dry or mixed with the surface-soil, or in the form of a tea made by pouring water over the soot in a vessel. Draw off the liquid after the mixture has settled and apply it around the roots of the plants, taking care that it does not touch the foliage. It is especially good for Pansies and Roses.

Manure-water is a good way to apply animal fertiliser, as it is fairly free from the seeds of weeds, which 
constitute the chief drawback to the solid form. To prepare it take a water-tight barrel or half-barrel and put a spigot in the side near the bottom. Place three or four inches of clean straw in the barrel, letting it come well up above the spigot, then fill half full of manure. It is not necessary that the manure should be so very old; it needs only to have passed the fermentation period. Fill the barrel with water. Fit a tight cover over it and it is soon ready to use. As long as the liquid runs the colour of coffee or a strong tea the manure will not need renewing, and more water may be added from time to time, but when it shows signs of exhaustion empty the barrel, put the refuse on the compost heap and fill the barrel as before. If the liquid is to be used on pot-plants it will be better to use boiling water in the barrel to destroy the eggs and chrysalis of the white-worms and other larvæ that infest the manure; or add a half teaspoonful of Paris green to the water. The first drawings from the barrel should be well diluted before using, especially when applied to dry soil. If hen manure is used, it should be made much weaker than other manures, as it is very heating and likely to burn the roots of plants. A convenient way to handle the manure barrel is to carry a watering-pot of water to the barrel each time, emptying it in at the top and drawing off a corresponding amount at the spigot-in this way the barrel is kept constantly full and extra steps saved. Liquid manure may also be 
prepared by filling a pail half full of manure, adding boiling water, and dipping off the liquid when the sediment is settled.

After a heavy rain there will often be a pool in some corner of the barn-yard where sufficient liquid manure may be dipped up to fill a barrel or hogshead. Where the barn-yard is paved with cobble-stones - as all barnyards should be, for health and cleanliness-a catchbasin may be easily arranged which the natural slope of the land will fill when it rains. This will more than pay for the trifling outlay for its construction, as it need only be a depression in the soil, covered with cement. Even stiff clay will answer. It is surprising how carelessly farmers let such valuable property go to waste while they buy load after load of manure at the stables in town and haul it long distances. The yield of the strawberrry- and asparagus-beds alone would be sufficiently increased to pay for such a catchbasin many times over.

Soapsuds furnish another excellent fertiliser, and every drop of water from the wash-room, bed-room and kitchen should be saved and applied around the roots of plants-especially Roses, Dahlias, and vines, which never seem to get enough of either moisture or nourishment. Slop-water should not be put on the foliage of plants, as it leaves a scum that is difficult to get rid of.

A very good substitute for commercial bone-meal miay be manufactured at home by saving alì the bonte 
from the kitchen, throwing them into a stone jar, covering them with strong lye, and allowing them to remain until soft enough to be pulverised and dug into the soil. The lye that remains may also be applied to the soil after being diluted with water. Blood obtained at the slaughter-house is an excellent fertiliser, containing much easily assimilated plant food in a soluble form. Feathers contain much valuable material in the way of phosphates, but are not suitable for the annual beds. They may be applied to shrubs and hardy perennials by digging them into the ground at a little distance from the plants, where the roots will reach out and find them. Hoof-parings from the blacksmith shop are also valuable for the perennial bed. Indeed, with all the forms of plant food available there is no excuse for starving plants. There are, of course, many commercial plant foods and fertilisers on the market, bone-meal and guano being the most reliable among them, but many of them are expensive and uncertain in their action. Being highly concentrated they are likely to do harm in the hands of the inexperienced. The natural manures are the. safest.

In using liquid manures either on the open ground or on potted plants, they should only be applied when the soil has been well watered the day before, never when it is dry. The plant, being supplied with all it needs to drink, absorbs only what it requires for nourishment and is less likely to be injured by an 


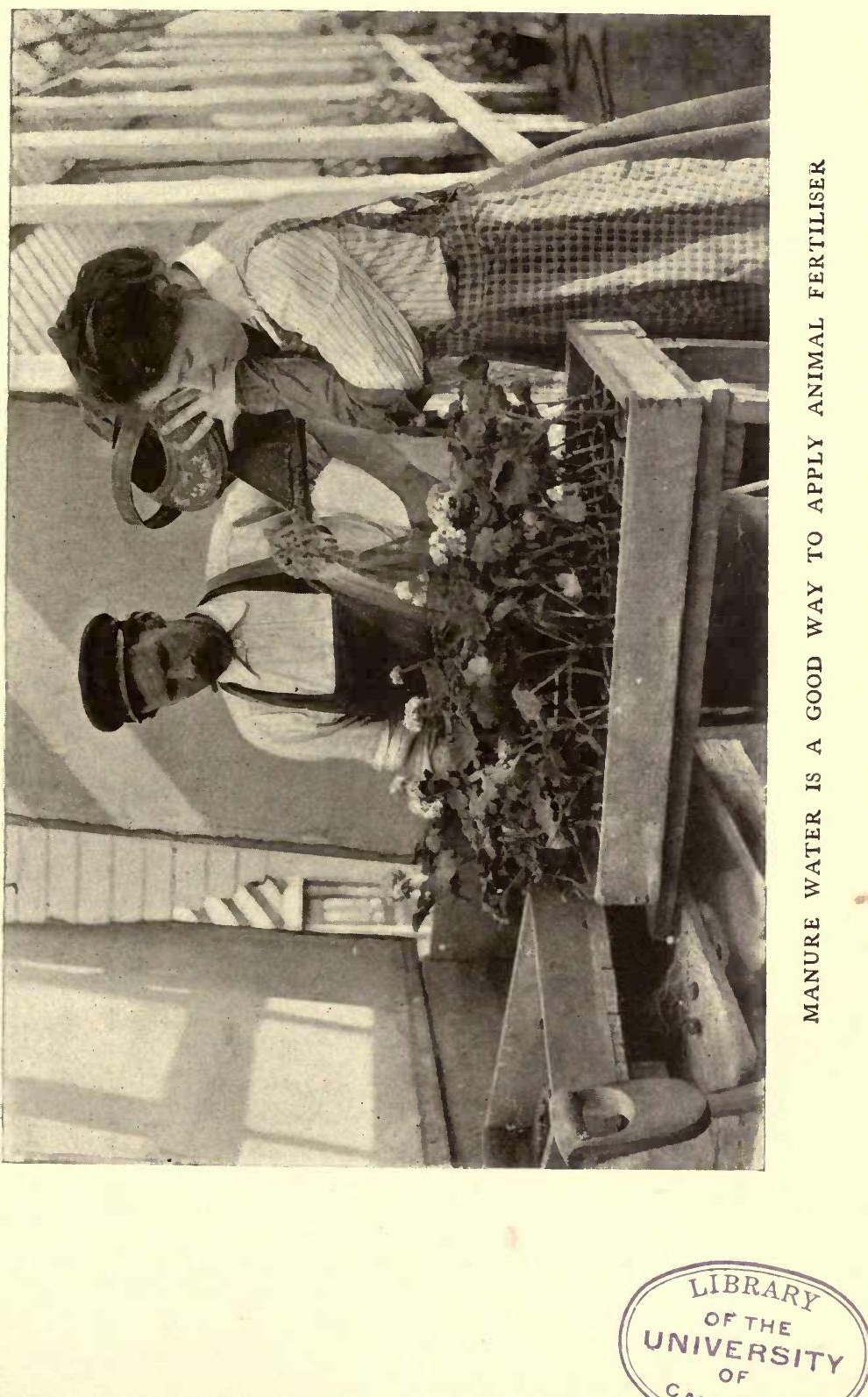




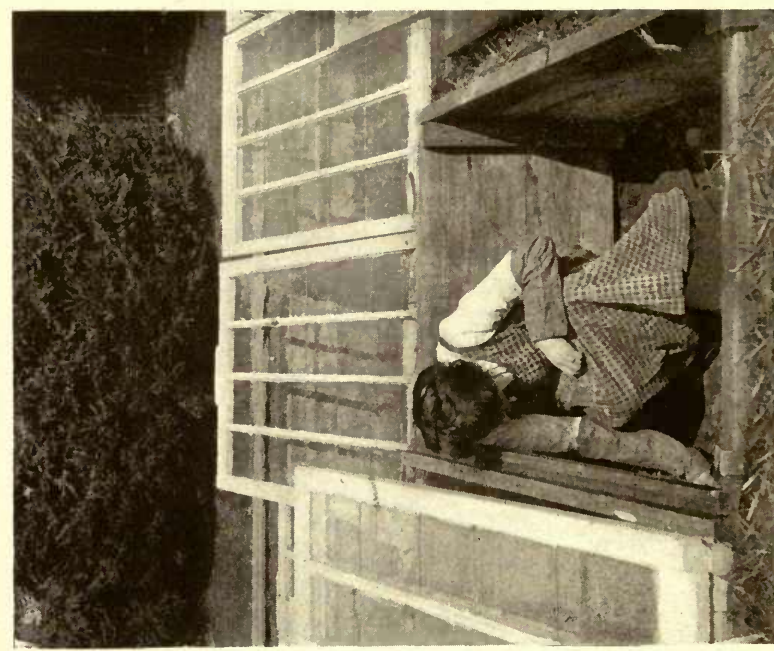

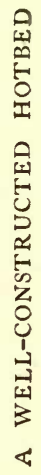

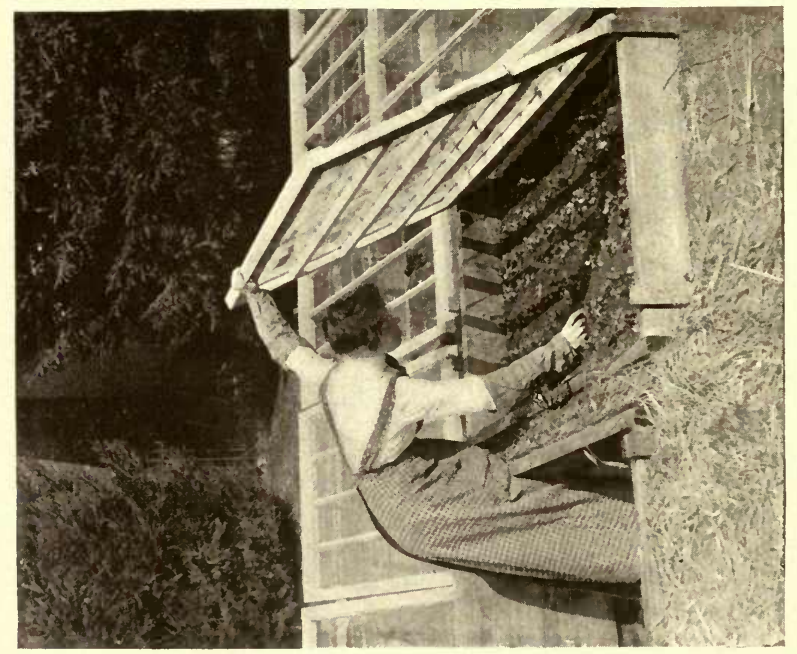

年 
overdose. The moisture in the soil serves also to reduce the strength of the manure.

In applying old cow or horse manure to new beds a wheel-barrow load to every nine square feet is not too much for strong growing plants such as Ricinus, Cannas, and Salvias. Half that quantity of hen manure will be sufficient. 


\section{Chapter FOUR}

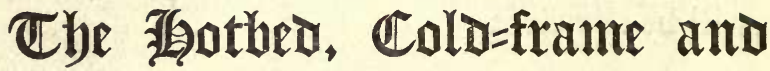 Sand $=$ box}

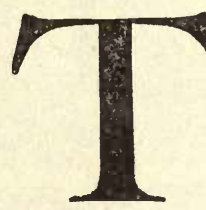

$\mathrm{HE}$ hotbed is an enclosure, affording bottom heat and protection from cold, for the propagation of tender plants unsuited to sowing in the open ground, and for starting plants too early in the season for open-air operations. The hotbed is usually started in February or March in the latitude of Philadelphia, while April is early enough in the latitude of Detroit and Chicago. Plants are transferred to the open ground when all danger of frost is past. With the exception of a few plants like Poppies, which do not bear disturbance, all seeds yield better results if planted where they have protection in their early stages from drying wind, burning sun and nipping cold. This protection the cold-frame gives, while the hotbed affords the additional advantage of artificial heat. Plants thus started will be ready to transplant about the time seeds could be started in the open ground-an important gain in northern latitudes, 
where, between the early and late frosts there is hardly time for the maturing of annuals.

The hotbed should be situated on the south side of a building, wall or fence, where it will have the full benefit of the sun and be protected from cold winds. It is also desirable that the land should slope toward the south, that all surface water may drain away, and that the bed may receive the greatest amount of sunshine during the day. In constructing a hotbed dig a pit two feet deep. This may be lined with planks or bricks, or left with its earthen walls. Over this build a frame of rough lumber around four posts of three- or four-inch stuff, three feet two inches high in the back, and two feet eight inches high in the front. If the pit is not lined, this will bring the frame below the surface and allow a sufficient slant for the free shedding of water and the concentration of the greatest amount of sunshine on the bed. Regular hotbed sash are three feet by six, and cost about two dollars and seventy-five cents each, glazed and painted. These are usually arranged to rest on the frame, simply sliding up and down, the size of the bed determining the number of sash. A bed three by six, however, is more easily handled than a larger one; and two or more beds, set end to end, or one long, narrow one divided by partitions into three-bysix beds, will be more satisfactory in every way than a wider one. The partitions are necessary, not alone to strengthen the frame and support the sash, but to 
insure to each section the special treatment it requires. Not all seeds germinate in the same temperature, or require the same degree of moisture. There is, also, a great difference in the period of germination; some seeds sprout in from three to five days; others require as many weeks. With separate sections seeds of similar habits and requirements may be planted together.

Florists' sash makes an expensive hotbed, and quite as satisfactory results may be obtained by using such old window-sash as may be picked up for about twenty-five cents apiece where buildings are being torn down or from junk or hardware dealers. Old sash will probably need some glazing and painting, and these are among the things the amateur gardener should learn to do for herself, as sash must be watertight and in order at all times. A sudden hail-storm, a mischievous cat or careless handling may leave one with broken glass that must be replaced at once. When old sash is used the back of the frame should be higher than the sides by the thickness of the sash, so that the sash may be fastened to it with hinges if desired. A cross-piece from the back to the front for the sash to rest on will give greater stability and prevent draughts of cold air on a sudden fall of temperature.

Having constructed the pit, fill it with fresh manure from the horse-stable-that from young, grain-fed stock being best. It must be perfectly fresh, gathered 
from the stalls in the morning, and should be mixed with a quantity of litter - long straw or leaves. This serves as fuel, insuring a continuous heat. Without it the heat germinated by the manure would quickly die out and the bed become cold. Throw the manure loosely into the frame, close the sash and wait for fermentation or heating. This should take place in from twelve to twenty-four hours; if longer than that it will be as well to throw out the manure and begin again, making sure this time that the manure is absolutely fresh. When the thermometer by rising to Ioo or more degrees shows that fermentation is well under way, the manure should be well tramped down, as level and smooth as possible. Over this place a couple of inches of fine, old, well-rotted manure. This will afford nourishment for the young plants should they make sufficient growth to need it, or on account of stress of weather be detained in the hotbed longer than expected. If this is not supplied the tender roots of the plants are apt to go in search of the crude manure in the bottom of the hotbed, and be injured by contact with it. When plants that have come up thrifty suddenly turn yellow and look as if they had been scalded, though sufficiently protected from the sun, it is probable that their roots have been burned by the manure. This may be determined by digging down to the roots. If they have reached the manure the cause is evident; other plants in the same beds, with shallower roots, it will be observed, are not 
affected in the same way. As this is not likely to happen until the plants have made considerable growth the season will probably be enough advanced to permit of planting out, especially with protection at night, or they may be transplanted into the coldframe until the weather is warm. Such mishaps seldom occur, but when they do, they must be met promptly. Few plants will make over four inches of roots before transplanting, and when they reach the old manure they usually spread out without going deeper.

To return to the construction of the hotbed: Cover the manure with four inches of rich, fine loam, free from rough lumps and stone; it would better be put through a sand- or coal-sieve if not mellow and fine. Make as level as possible, and place a thermometer in the soil to register the temperature. When it has risen to 90 degrees or above, and then fallen to 75 or 70 degrees, the seed may be sown.

In planting seed it is best to use narrow strips of wood to separate the different varieties. This prevents mixing and running together when watered. It is impossible to distinguish between different varieties of Asters, Ageratums and Pansies once they have become mixed. Where one lives within reach of a box factory narrow strips of wood-admirable for this purpose - of uniform width and very thin, may be readily obtained. It is best to begin at the upper right-hand corner with seeds that require the most 
time to germinate, labelling each section plainly with name, date and the period of germination.

Flowers that make the tallest growth may be placed against the back with advantage-as Cobæa scandens, Ricinus, the Dolichos, Cosmos, and the like; giving them the advantage of the extra light and keeping them from withholding the light from the plants in front of them.

Coarse seeds should be planted in drills and covered to twice their depth. A furrow may be scratched with a sharp stick from an eighth to a half-inch deep, and the seed sown thinly in it, the earth being replaced and pressed firmly down with a piece of wood. This is important, as it brings the seed in close contact with the earth, and the tiny sprout can lay hold of it at once when germination takes place. Many seeds of weak germinating power are lost when sown in loose, coarse soil by failure to obtain immediate contact with the nourishment contained in it.

Fine seeds like Petunias, Nicotianas and Ageratums must be sown broadcast in little squares reserved for them. Sow on the surface, press into the soil with a piece of board and merely sift fine sand over.

A piece of thin wood eight or ten inches long and four or five inches wide, with a handle on one side, will be found very useful to press the soil down quickly and firmly. This should be an adjunct to every wellregulated hotbed. So should a thermometer, hung on the back wall of the hotbed, the bulb level with 
the soil. After the seeds are all sown, if the soil is at all dry, sprinkle carefully with a rubber sprinkler, or a whisk-broom dipped in water and shaken over the bed. Do not use the watering-pot, as it will wash the seed out of the ground. When the plants are up and of some size the watering-pot may be resorted to, but not before. When all the seeds are sown as directed cover with newspapers and close the sash.

The most careful attention must now be given the hotbed. If the temperature rises above 75 degrees in the warmest part of the day the sash must be raised an inch or two. In doing this, if the wind is cold, it will be best to slip a strip of wood between the sash and frame on the windward side, or protect the opening on the windward side with a bit of carpet.

When the seeds in any particular plot show a single pair of leaves, remove the paper over that much of the bed, still shading from the sun during the hottest part of the day by a bit of paper on the glass directly over the plants. When the plants appear too thickly in the row, transplant them as soon as they have their second leaves into other rows between the first, or into another hotbed or cold-frame. Encourage vigorous growth by giving room to develop and as much air and light as possible.

As soon as the plants are of sufficient size and the weather is warm enough, remove the sash during the day, replacing it with screens made of lath. These screens are easily made by nailing strips of lath, the 
width of the hotbed, to strips of wood the length of the bed. The lath should be set its own width apart, and the nails, of which there should be two in each end, clinched on the under side. Such screens are a necessary part of the hotbed, and will last for years.

Before transplanting to the open ground these screens should be removed entirely and the plants left exposed to the weather for a few days to harden. Screens of chicken netting may be substituted, if protection from cats, dogs or chickens is needed. If, in the early stages of the hotbed, drops of moisture gather on the glass, the soil is too wet and the sash must be raised to allow the surplus moisture to pass off, avoiding always a cold draught across the bed.

The cold-frame is simply a frame of boards fitted with sash and placed over a prepared bed of earth. As the bed will be raised slightly above the surface of the soil, the frame should be set over it, shutting out the cold from the sides as well as the top. A covered bed, prepared without heating material, is a coldframe; and one in which the heating material is spent is often used as a cold-frame after it has served its purpose as a hotbed earlier in the season, for growing Gloxinias and rooting cuttings during the summer, and in August for sowing Pansy seed for the next summer's blooming. Cold-frames are useful to protect beds of such tender perennials as Tea-roses, Pansies, Canterbury-bells, Foxgloves and Violets. Violets 
may, by this means, be kept in bloom during the winter. They are also useful for bringing forward, early in spring, beds of Hyacinths and Narcissi. They should be protected by carpets or mattings at night and during the colder days, and exposed to the heat of the sun on bright days when the soil is not frozen. When it is, they must remain covered and thaw out in the dark, to be aired when the weather is above freezing, but draughts across the bed must be avoided, as they will certainly blast any buds there may be.

The cold-frame in winter must have good drainage, or much damage will ensue from water standing around the roots of plants. The surface of the bed must be above the level of the land outside and a trifle lower at one corner. From this corner a trench should be dug having an outlet, or a deep hole may be dug and filled with broken crockery and stones to carry off all surplus water.

The sand-box is a receptacle for the summer storage of plants which are not to be bedded out. It is also used to prepare plants for winter blooming, and for experiments with novelties in house-plants. It is, finally, the ideal place for rooting cuttings. I have never known a plant capable of being started from cuttings that would not take root in the sand-box. Any shallow box that may be- reached across easily is suitable for this purpose; or a deep box may be cut down to six or eight inches and rendered available, the length depending on the plants to be accommon- 
dated and the room at disposal. The sand-box should be placed, if possible, in a convenient place on the east side of the house. Elevate on saw-horses, blocks, posts or a regular frame to a height easy to reach when sitting in a chair. Fill nearly full with clean white sand; in this bury the pots nearly to the brims and keep the sand constantly wet.

Plants that can stand full sunshine-as Geraniums, Crotons, Heliotropes, etc.-should be placed in front; those requiring more shade may be in the second row, and those needing the most against the wall. Vines, also, may be trained against the wall, and over the sides of the box, if it is desired to make it beautiful as well as useful. A wooden chair should be placed conveniently near, and the space underneath may be utilised for ferns, or the storage of tools and pots.

Once established, the sand-box will be found one of the most fascinating of spots. Cuttings of all kinds may be thrust into the sand between the pots-Geraniums, Carnations and Roses in front. Gloxinias and Begonias - with the leaves laid flat on the sand in the rear-will quickly take root in it. No one who cultivates a garden, or house-plants, should try to get along without a work table or bench, and this should be situated in some cool, shady spot out of doors. It may be either a large kitchen table or a large packing box, the latter being preferable, perhaps, as affording shelter for the various tools used in working. It should be high enough to work at conveniently when 
standing up, and a tall stool should be provided for sitting on when desired, to be pushed under the top of table when not in use. There should be a shelf underneath, sufficiently roomy to hold a supply of pots and flats, and, below it, a box of potting soil and one of fine white sand should be kept ready for use. If the potting soil lies on the ground it will keep moist in the dryest weather. A tin pail of pebbles, broken crockery and charcoal for drainage, and a supply of sphagnum moss should also be kept handy. A trowel, knife, shears, pencils and a stick-or, better still, a piece of a broken carving-steel-for pushing a plant out of the pot by inserting it in the drainage hole when, for any reason, it is not readily removed by tapping, will greatly lessen the labour of repotting and shifting house-plants in summer.

A shallow tray, with a bail of wood, large enough to hold a number of pots, will be useful to carry plants from the potting table to the sand-box, and will save many steps. With a well-equipped table to depend on and no litter around the house, one is much more likely to give plants necessary attention promptly. The work then becomes a pleasure instead of a labour to be dreaded. There, too, may be kept the supply for staking plants. The nicest stakes for house-plants are made of Cat-tail stems, any quantity of which may be gathered in the fall and stored away for future use, each stalk furnishing two or three stakes. Being round and smooth they are sightly and just what is needed for Carnations, Freesias and the like. 


\section{Chapter FIVE \\ 羽urbasing of Seros}

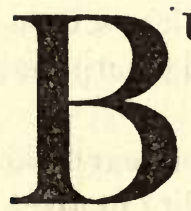

UYING seeds is largely a matter of experience. So glowing are the descriptions in the numerous catalogues sent out that one may easily be led into ordering many worthless novelties, and many desirable ones for which there is neither room nor sufficient knowledge of their wants to grow them successfully. Cheap collections, where one is requested to send ten cents for a catalogue and twelve packages of seeds, are worst of all.

In buying flower-seeds, as in everything else, one never gets "something for nothing" - not even experience, and cheap seeds usually prove a very poor investment; the only safeguard is to buy of trustworthy dealers whose seeds are offered at fair prices. Take, for instance, Pansy seed: one ought not to expect to buy a fine mixture in a full-size packet-two hundred and fifty seeds-for less than twenty-five cents, while such varieties as Giant Trimardeau and Giant Cassier should be fifteen cents or more, according to the place

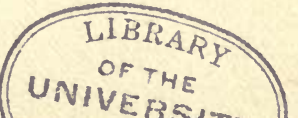


of purchase. A few of the old favourites-like the Snow Queen-may be bought in packets costing from three to five cents and prove good value. But generally speaking, packets selling for less than five cents are to be looked upon with suspicion. Seeds bought at the grocer's or other local dealer's are likely to be old or inferior stock-the better class of seedsmen selling direct to the consumer only. At the end of every season seedsmen have a large stock left over. The best concerns destroy these, but the less scrupulous put them up as prizes for advertising purposes, or sell them to the local dealers.

Some varieties of seeds retain vitality for years, like the Morning-glory, while others lose vitality in a few months or weeks, like the perennial Phlox, which must be sown as soon as ripe. From this it can be readily seen how worthless some of the seed carried over from year to year must be. As an experiment, I planted under glass in the house, with more than usual care, a part of one of these trial packages of twelve for a quarter. From five of the packages I got just one plant-a Lantana, while from the sixth I grew a number of inferior Petunias. In striking contrast to this I planted, under the same conditions, a packet of Bush Hill Pioneer Cyclamen containing twelve seeds, for which I paid fifty cents, and secured eleven plants, every one of which lived, making four and a half cents apiece for a very choice variety of Cyclamen, while the one little common Lantana cost me ten cents. 
The prices of one firm will frequently be much . higher than those of another equally trustworthy, the difference being caused, in most cases, by the number of seeds in the packets. A few firms now state the number of seeds in their price-lists. This should become the general practice. There is manifest injustice in selling packets containing a quantity which is entirely problematical, and often much below what the purchaser has a right to expect. To advertise seeds much under the usual price and reduce the number accordingly is a common practice.

It is better to buy a few good seeds, and by careful cultivation bring the plants as near perfection as possible, than to buy a quantity of cheap seeds. One can join with a friend or neighbour and thus secure a larger variety at less cost than would otherwise be possible. Generally speaking I think it a great mistake to save one's own seed. Few choice varieties are fixed and so tend to run out in two or three seasons. From fine strains of Asters you may save seed that will give good results the first year, but flowers grown from seed saved from these will show more or less centre, so that fresh seed should be purchased every other year at least. As the bees do not visit the Asters so assiduously as other flowers, they are less given to hybridisation and come quite true from seed; the trouble with them being deterioration. The first flower on the plant is usually the best, and should be reserved for seed by tying a string around it and label- 
ling it, if it is desired to keep the varieties separate. Remove all other blooms on the plant, as they fade, allowing only the one selected to ripen.

Pansy seed should never be saved, as the ripening of it weakens the plant and checks its blooming. Pansies growing in a mixed bed never come true from seed and deteriorate rapidly. Growing Pansy seed is work for the Pansy specialist, but if it must be saved a few plants should be grown in a bed by themselves and covered with a netting to keep off the bees, which work incessantly over the Pansy bed. Not more than two or three of the finest flowers on a plant should be allowed to seed, all other buds being removed as they form, and the plants kept in a high state of cultivation and supplied with liquid manure at least once a week during the season of seeding.

Seed may be saved freely from Poppies, as they do not deteriorate appreciably, and the hybridisation constantly going on results in a wonderful variety of form and colouring. The ripening of one or two capsules of seed does not materially affect the period of bloom; but it is well to mark one blossom on each plant, giving a preference to the terminal blossom on the main stalk, as being usually the finest. Remove all other blossoms as they fade. Perennial Poppies will do better, however, if no seeds are allowed to form. Morning-glories, Cosmos and Verbenas sow themselves better than the gardener can, the plants being much more vigorous than from the hand- 
sown seeds. Verbenas mix badly, and are apt to hark back to the original purple strain, or come striped. The seeds of the pink variety come true, I find, and some of the finest pinks I have seen were from selfsown seed. They range in colour through all the shades from pink to deep rose. A fair proportion of white may also be expected, but scarlet and red with a white eye are shy and rarely appear.

Nasturtiums rarely come true from seed, and if one desires a particular colour or shade, she must either buy fresh seed or grow that particular variety alone. If, however, one simply desires an abundance of bright flowers with a preponderance of yellow, orange and scarlet, it is worth while to save seed, as its vitality is remarkable and every seed may be expected to germinate.

No variety of Petunia can be depended upon when grown in a mixed bed. A particularly fine variety may be lifted and planted on the opposite side of the house, either in the ground or in a window-box, or in a pot in the house. From one exceedingly fine specimen of the large ruffled variety, lifted and grown in a window-box on the opposite side of the house from the Petunia bed, I saved a single pod of seed from which I grew, the following year, sufficient plants for a large bed. No two of these were alike in colour, but they retained the immense size, ruffled edges, velvety texture and beautifully marked throats of the parent strain; some were a velvety crimson, nearly 
black, some white with crimson blotches, and some showed rare shades of grey.

Sweet Alyssum sows itself, and the trouble is usually not to save but to get rid of it. Candytuft may be saved, but the fewer flowers allowed to seed the better for the continuation of bloom. Where one does not actually need the seed all flowers should be removed as fast as they fade. No one thing will add so much to the appearance of the garden as this, as nothing is more untidy than flowers gone to seed.

Perennials are greatly benefited by having the withered flowers removed; indeed so noticeable is the advantage that some, like the Monkshood, will give a second crop of flowers, and those that will not respond in this way will be more robust and bloom more freely the next year.

Vincas, too, and Hibiscus bloom more freely if not allowed to seed, while Coleus should not even be allowed to bloom. Sweet-peas must on no account be permitted to seed unless grown for the purpose, Seed may be gathered from the Thunbergia, Mau randya, Adlumia, common Morning-glory and Hollyhock without risk of deterioration or harm to the vine. Antirrhinums suffer severely from seed-bearing, while the Ricinus, Lantanas and Salvias may be allowed to seed freely. Ageratums look rusty when ripening seed, and it pays to go over them frequently with the shears; this will keep them fresh and full 
of bloom until frost. One flower-head will furnish all the seed one is likely to want.

All seeds should be gathered when ripe and the foliage dry. They should be exposed to the air in any convenient receptacle, except in the case of the Thunbergias, Balsams, and others having pods which snap open and expel the seeds to a distance. These should be saved in paper bags until perfectly dry, when they may be freed from their husks by sifting or winnowing, and stored in paper bags, envelopes, or boxes. It pays to save the florists' envelopes for this purpose, as they are already labelled. Never put seeds away unlabelled, and it is a good idea to add to the label the date, period of germination, with the colour of the bloom, height, and other data of interest. It is still better to keep a book of such information to which one may refer from year to year. There are frequent doubts concerning some operation-the season of starting the hotbed, the time it took a certain class of bulbs to bloom after potting, and the like. In all such cases the note-book offers unimpeachable evidence. 


\section{Chapter $S I X$}

\section{Starting Seros in Jfats}

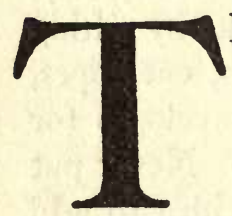

HERE are many choice seeds, especially in the greenhouse varieties, that cannot be handled successfully in the hotbed-Begonias, Gloxinias, Cinerarias, and Primulas among them. All seeds too fine to be covered do better with house treatment. For starting these the shallow boxes or flats, as they are called, are used. Shallow cigar-boxes, or the larger ones sawed in two and the lid nailed on for the extra bottom, make convenient sizes for the finest seeds. They may be used from year to year if care is taken to store them away, at the end of the season, where they will keep dry and ready for use.

Holes for drainage should be bored in the bottom and covered with bits of glass or broken crockery. Fill with finely sifted leaf-mould to within an inch of the top and shake the earth smooth and even. A smooth piece of board, three inches wide and as long as the inside width of the flat, with a handle that can be easily grasped, is indispensable for pressing down the soil, both before and after sowing the seeds. 


\section{Starting Serds in Jflats}

It should be stored away with the flats at the end of the season.

Sow very fine seed broadcast, scattering it thinly and evenly over the surface and pressing it into the soil with the wood. It will be better to sow only part of a packet at a time. This will usually give all the plants of a kind wanted at one time, and if success does not follow this first trial there will be seed left for another sowing. Label plainly with the name and date of sowing, and, when known, the date of germination. Give the soil a thorough watering by setting the flat in lukewarm water until the water rises to the surface, but not above it. When the entire surface is wet, remove the box, draining off all surplus water by tipping on one corner, until the water ceases to run off. Cover the flat with a glass and sheet of white paper and place in a warm place - a shelf above a coal-stove or radiator is an excellent location, as it affords the bottom heat so essential in starting tender seeds. Seeds while germinating need but little light, and a box on a shelf in a living-room may be so screened as not to be unsightly. A shelf under another, having a light valance, is an ideal place, as the heat strikes more on the bottom of the box, leaving the top cool. Coarse seeds may be sown in rows and lightly covered, or enough fine white sand to merely cover may be sifted over them. Large seed, like the Asparagus Sprengeri may be pressed into the soil to twice their 
depth. Or the soil may first be covered with a thin layer of fine white sand, and the seeds sown on this and covered according to need. Sand counteracts the troublesome tendency to damping off caused by the presence of a minute fungus in the form of a fine moss or thread-like filaments covering the ground. Since this is the result of too much moisture, the remedy is to remove the glass, allowing the surplus moisture to pass off and the dry air to strike the soil for a short time. Care must be taken that the dryness does not extend below the surface. Drops of water on the glass indicate too much humidity. The glass should be removed, wiped, and aired. Where the plants are not too close together a crochet-hook or hat-pin may be used to scrape the moss or filament from the earth. This slight disturbance of the soil often serves to destroy the fungus. If the soil threatens to become dry, water carefully with a rubber sprinkler. If the dryness begins in the bottom, water as before by setting the flat in a pan of water.

When the plants have their second leaves give more air and remove the paper; in a day or two set in a light, warm window, screening from the hot sun by placing a piece of white paper between the box and the window glass. Leave the glass partly off the flat to admit air, and when the plants have their first true leaves remove it entirely for a part of the time.

When large enough to handle, transplant the seedlings into other flats, setting them one or two inches 


\section{Six] Starting Serds ín Jflats}

apart according to their growth. When the leaves again touch prick them out in two-inch pots of leafmould, placing a piece of crockery over the drainage hole and filling with earth to within half an inch of the top. Plunge the pots into a box of sand in a sunny window until large enough to go out of doors. As soon as the roots fill the pots shift to a size larger, using compost of two parts fibrous loam, four parts leaf-mould, one part old, well-rotted manure, and one part sharp white sand, all thoroughly sifted together. This is called fine compost, while soils that have not been sifted are known as rough compost. To remove sticks, stones, or hard bits of root put through a sand or coal-ash screen. A piece of wire netting slightly gathered up in the hand makes a convenient screen for a small quantity and a box with a netting bottom for larger quantities of earth.

By the time the plants again need shifting it should be warm enough to bed out all those that are to grow in the open ground, while those intended for the house must be shifted from pot to pot as they outgrow their quarters and be given such special treatment as the individual plants may require, always aiming at as thrifty a growth as possible. Plants intended for winter blooming must have all their buds removed and their branches pinched back according to their summer development.

Weak liquid manure may be given once a week during summer. Keep the sand in the sand-box wet 
at all times, but do not over-water. Water thoroughly and then allow the earth to become nearly dry before watering again; this alternate moisture and dryness allows the wood to ripen and make a stockier growth and one that will stand frequent changes of temperature better than the tender growth induced by over-watering. 


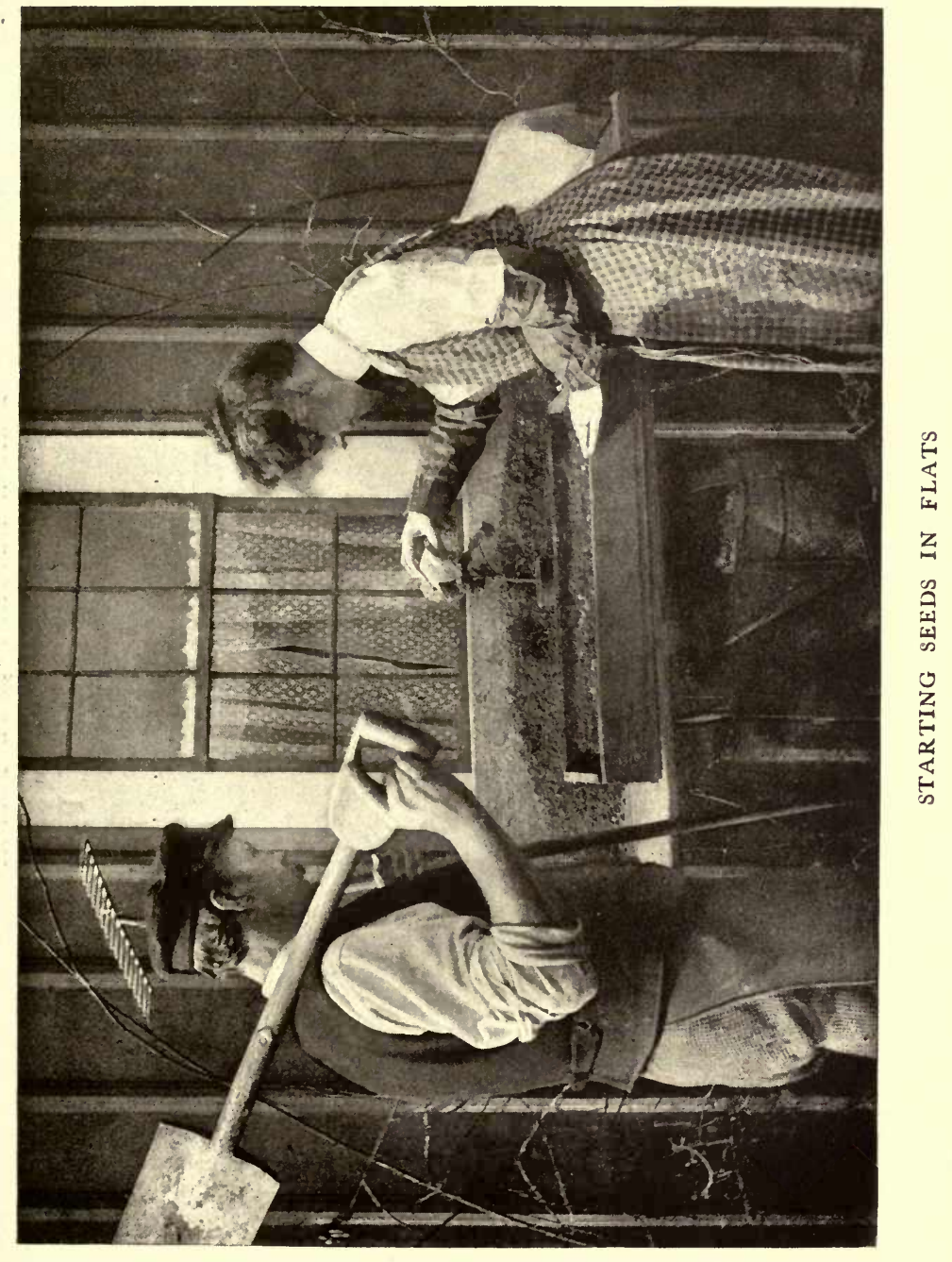




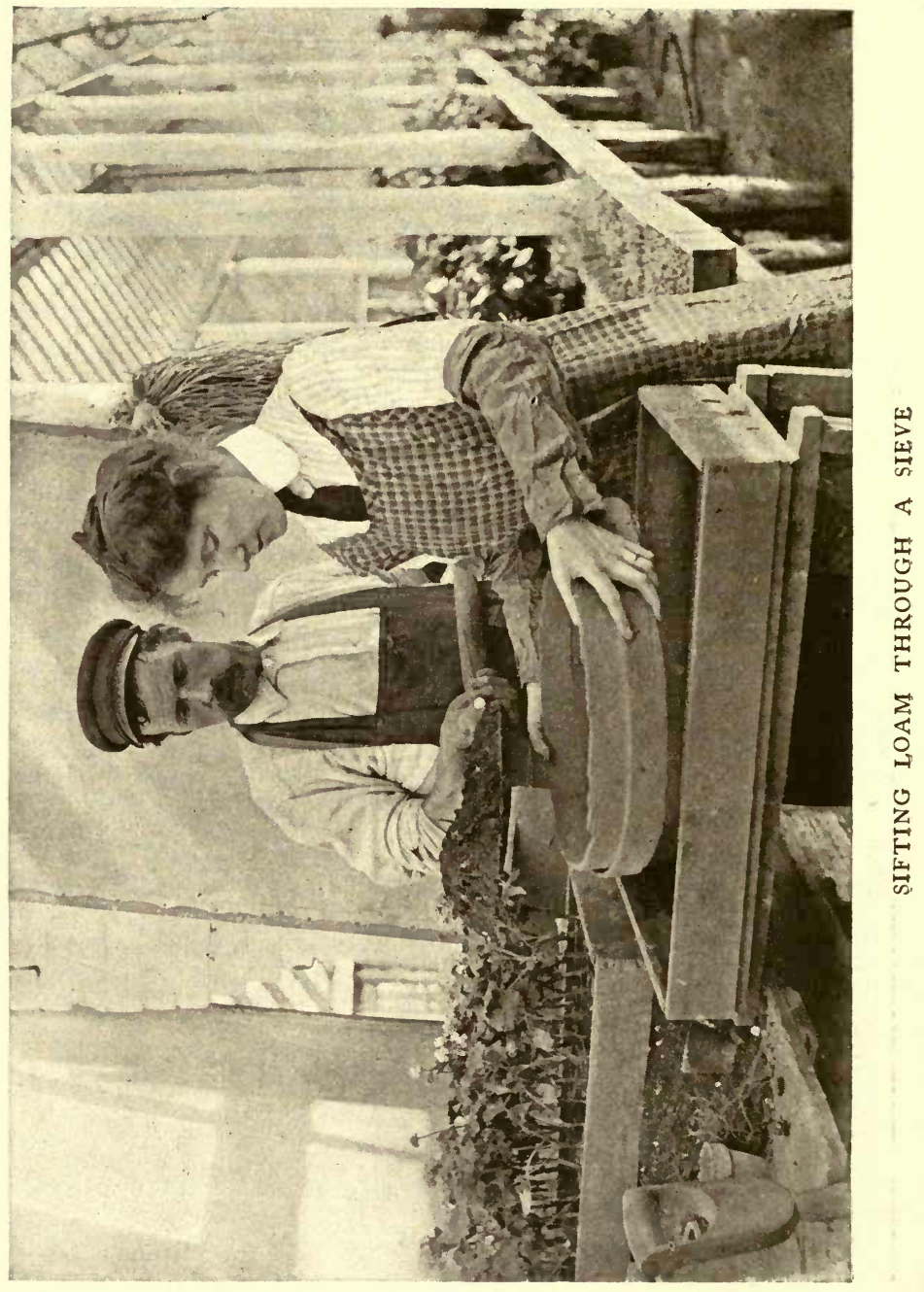




\section{Chapter SEVEN}

\section{Transplanting and Repotting}

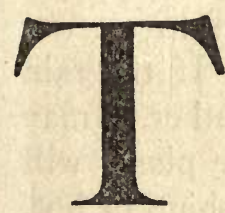

ENDER annuals should not be planted out of doors until all danger of frost is past-usually about the twentieth of May in the latitude of Detroit and Chicago, and correspondingly earlier in the latitude of Philadelphia. Corn-planting time is safe in all latitudes. Even hardy annuals, if not too crowded, do better in hotbeds and boxes until the nights are warm. Vines especially suffer from cold nights and cold ground, and often receive a setback from which they may not recover all summer.

It is best to prepare the beds a few days in advance that they may settle, as freshly dug soil is too loose for the roots of tender seedlings.

For solid beds of one flower make straight, parallel rows about nine inches apart for plants like Pansies, and from twelve to eighteen for Asters and their kind. A most convenient method is to use a board the length of the bed, or as long as convenient, with the distance between the plants marked on it. By 
using a board wide enough to stand or kneel on, stepping on the bed is avoided. On a round bed the lines may run straight across or they may radiate from the centre, in which case it will be necessary to skip a part of every other row, as the rows run together at the top.

It is better to transplant on a bright, warm day when the soil is dry than on a damp or wet one. Never transplant when the soil is wet. Many people take advantage of an approaching rain to set out plants, but this is a doubtful practice. If the rain is followed by several days of cloudy weather, it may do, but if followed by hot sunshine the plants will suffer more than if first planted in sunshine in hot, dry weather.

Only as many plants should be lifted from the hotbed at one time as may be transplanted before they wilt badly. The plants should be well watered the night before, that they may have a good supply of moisture stored, and that the soil may be moist and cling closely to their roots.

With the trowel make a hole deep enough to receive the roots without crowding, place the plant, fill the hole with water, and when that has partly disappeared press the earth firmly about the roots. Work the surface earth fine and smooth about the plant, taking care that it is perfectly dry. If, after setting the bed, wet spots appear, go over them carefully with dry earth. Do not cover or protect in any way; far 
more plants are lost by so-called protection than by any other form of mismanagement. If the planting has been done properly the roots will keep cool and damp-the mulch of earth preventing evaporation. This being the case, the tops will take care of themselves if sun and air have free access and the wind can sweep across them. Planting, as it is usually done-with the surface left wet, and the air shut away from the top-causes the water to evaporate rapidly in the hot air, and the plant is literally cooked to death. The water applied to the roots at planting will usually last for several days. The condition of the soil may be ascertained by removing a portion of the surface. If the earth underneath is found to be drying out too much make a hole on one side of the plant and fill it with water as before, carefully replacing the mulch of dry earth. Should it rain before the plants have become established the earth must be worked over as soon as it begins to dry that the moisture may be retained. If these directions are carefully carried out the tenderest plants may be transplanted in the hottest sun without injury. Occasionally a plant will wilt from exposure before planting, but it will be all right the next day-unless it was really injured before being placed in the ground. I repeat the caution to lift no more plants at one time than may be set in the ground before they wilt; to form a fine mulch of dry earth over the soil; to cover plants in no way, and to use no water on the surface 
for a few days until they have become established, which they will indicate by spreading out their leaves and making ready to grow. This method of planting should be followed in moving plants from one part of the garden to another, in resetting clumps of perennials, in bedding out house-plants and those received by mail. Where these last have had part or all of the soil removed it will greatly benefit them to set them in pots until these are filled with roots.

It is desirable that young plants should be kept growing vigorously all the time, and frequent shifting is necessary. Whenever the earth becomes full of roots, or the ball of earth is covered with a network of roots, the plant should be shifted into a pot a size larger.

"Shifting" means changing the plant to a pot a size larger without disturbing the ball of earth, while "repotting" properly means an entire renewal of the soil, the same sized crock being sometimes used. Shifting may be done at any time, even though the plant be in full bloom, while repotting should be done when the plant is dormant, as it is likely to cause the buds to blast and the foliage to droop. Plants less than a year old are better shifted than repottedespecially such as have neither bloomed nor shown any decided tendency to rest. After blooming and resting, if they are in as large a pot as you care to handle, they may be repotted in fresh soil, care being taken not to injure the roots, while dead roots should 
be removed with the shears. When a plant has outgrown its pot and it is inexpedient to give it a larger one-especially if it is not making a very vigorous top growth, part of the roots may be removed by running a knife down on two sides of the plant, which should not be disturbed afterward until the roots begin to grow anew, say, in three or four weeks, when it may be repotted with good rich soil.

In shifting plants turn them out of the pot without disturbing the ball of earth. This may be done by placing the hand over the pot, reversing it and giving it a sharp tap on the edge of the table, which will loosen it. Sometimes, when a plant has become pot bound, it will stick to the sides of the pot, when a stick inserted in the drainage hole against the stone in the bottom will usually loosen it. Having removed the plant from the pot, take out the old drainage material carefully, place in a pot a size or two larger an inch or two of broken charcoal covered with a little sphagnum moss to prevent the earth working into the drainage and clogging it. Fill in as much earth as the difference in the size of pot seems to require, working it well up around the sides with the trowel; press the old pot into this to make a hole the proper size and shape; place the plant, press the earth around it, and add more if needed. Water well and return to its place on the shelf or in the sand-box.

In potting some plants will require to have the soil pressed much more firmly around the roots than 
others. Those which make a soft growth, such as Impatiens sultana, various Primulas, Cinerarias, and most tuberous plants, like Begonias and Gloxinias, may be potted rather loosely, that is, with the earth pressed down lightly. Geraniums should be potted much more firmly, while such hard-wooded plants as Roses, Hibiscus, Otaheite Orange and Fuchsias, should be potted very hard indeed. Many failures in plant growing may be traced to neglect of this rule.

Cuttings of common house-plants are so easily rooted that it seems almost superfluous to give directions for handling them. Geraniums, Petunias, Coleus, and the like will rarely fail to root if stuck in the ground by the side of the plant; they will do still better if placed in the sand-box. On the whole I prefer to set them in small pots of earth plunged in the sand-box and kept moist, as by this method they do not suffer the shock of disturbance when ready to pot off.

A word about the selection of cuttings will not be amiss, as failure to choose wisely often results in the loss of the cutting, or in a poor or straggly plant. Quick, tender growths are not suitable for cuttings, except in the case of the Chinese Hibiscus, where the extreme tips are used for rooting; hard or woody growths are equally undesirable. The part where the new wood begins to harden and will break with a snap is best. No cutting should be over two or three inches long. The little, stubby side branches 
on Geraniums are best, and as soon as growth begins these should be pinched back to within an inch of the ground, or to the lowest buds on the stalks; this insures a stocky plant, branching close to the ground. Heliotropes do not root readily and should be started in wet sand in full sunshine and covered with a glass, which should be lifted occasionally to allow the surplus moisture to pass off, or in a bottle of water hung in a sunny window. Rose cuttings are so easily and so quickly rooted in the sand-box that it seems a waste of time to try any other way. In cutting Roses for bouquets, during summer, one should be generous with stems, cutting down to a robust leaf-bud in the axil of a leaf. After the Roses have faded the stems may be used for cuttings, dividing them into as many lengths as the buds allow, leaving two or three buds to a cutting. By this method one may have a large number of young Rose plants with little trouble and no expense. Coleus cuttings are quickly rooted by putting them in a glass dish filled with water and set in a warm place. If in the fall it is desired to save choice varieties growing on the lawn, large cuttings may be taken of the finest plants. Grouped together in a bowl, they are sightly and root readily. As the plants begin to grow they are likely to lose their large leaves-the new growths starting at the axils of these push them off-injuring the appearance of the plant. They should be potted off as soon as possible, the tops pinched out, and the plant encouraged to grow vigor- 
ously. To this end a warm, even temperature is necessary, sudden chills being fatal.

Gloxinias may be started in the sand-box by laying a leaf flat on the sand, in partial shade, covering the stem end with the sand. A callus will soon form, followed presently by a bulb. This may be as large as a hazel-nut before top growth begins. When tiny leaves appear the plant may be lifted and potted and grown until it blooms. It is not necessary to rest Gloxinias-either from seeds or cuttings-before they have bloomed. Begonias and Achimenes are rooted in the same way. Umbrella-plants are started by placing face down in a dish of water in the sun. Rubber and any other hard-wooded plants may be rooted by making an incision in the under side of a branch near a leaf, at a point where the wood has begun to harden, and wrapping the wound in a quan. tity of sphagnum moss, kept constantly wet. A thread should be tied to the branch on the side farthest from the main stalk and attached to a limb above to hold the cut slightly open that it may quickly become calloused. After a time roots will make their appearance through the moss, when the branch may be removed and potted. A method sometimes employed, when it is desired to save the crown of a plant which has a leggy or unshapely undergrowth, is to partly sever the stem at the point at which it is desired to root the plant, cutting out a wedge-shaped piece and packing with sphagnum moss. Or a small 

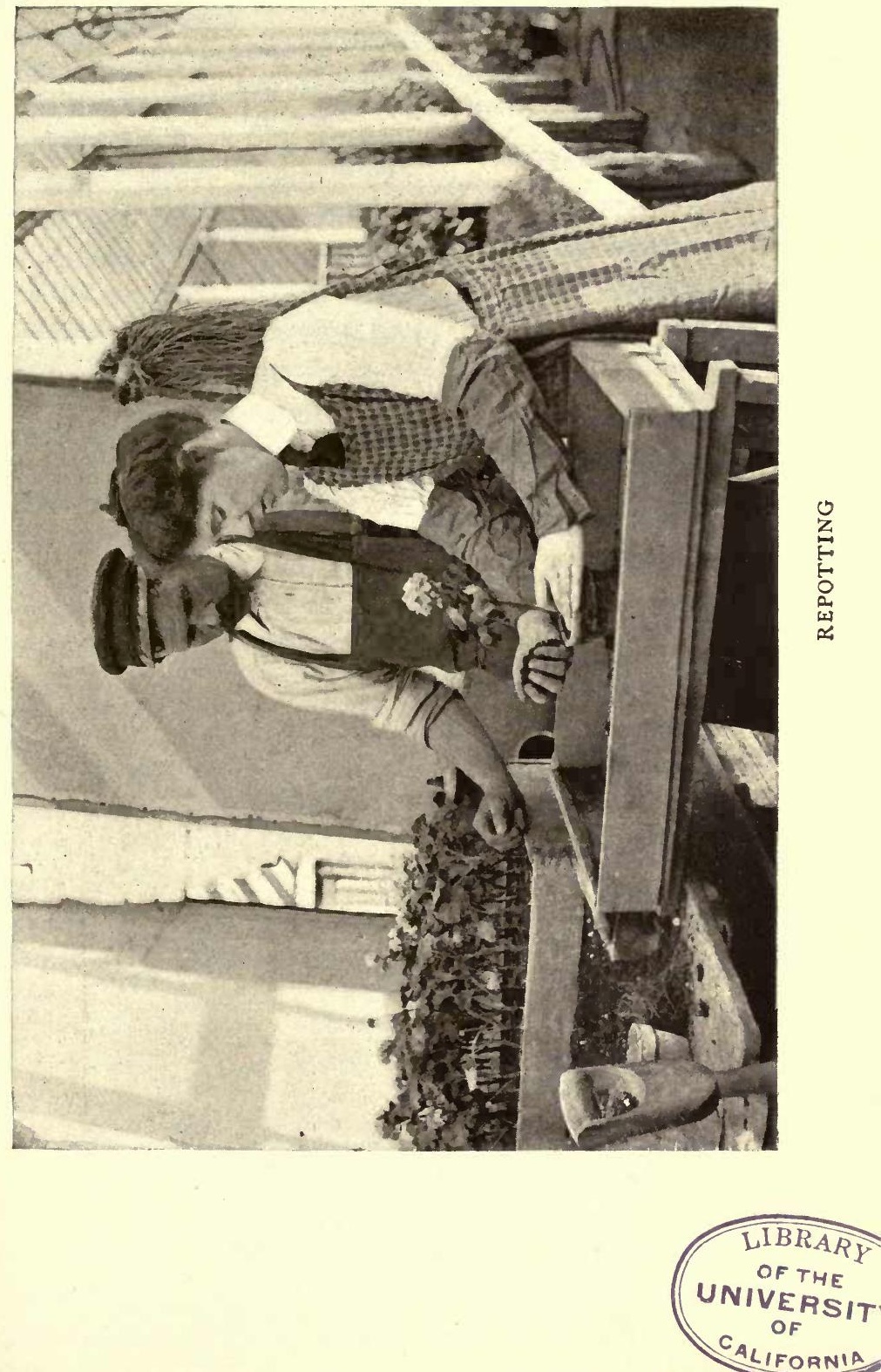


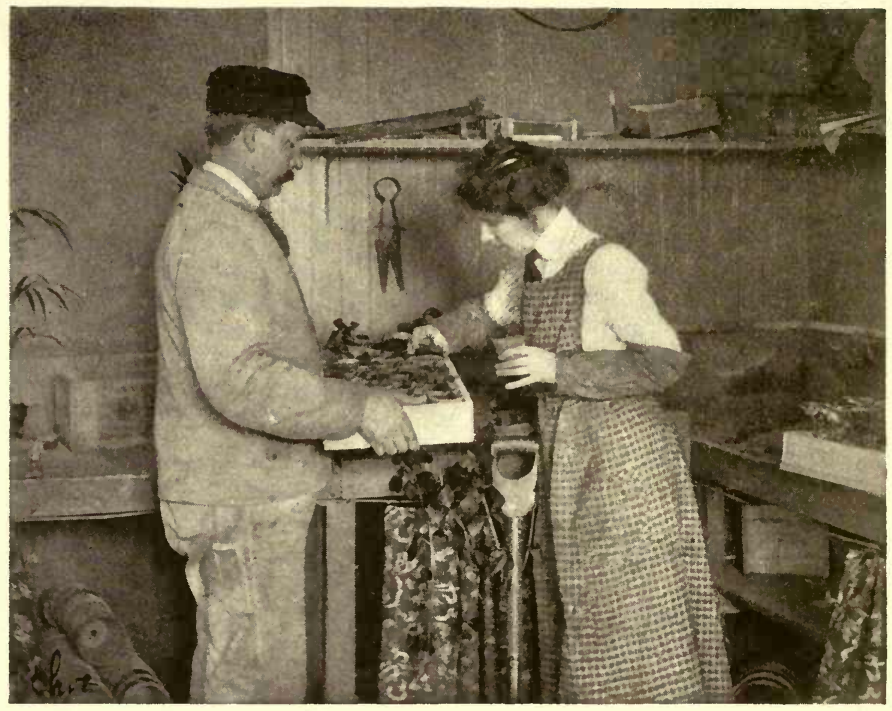

WHEN TWO OR THREE INCHES HIGH, TRANSPLANT CARNATIONS INTO POTS

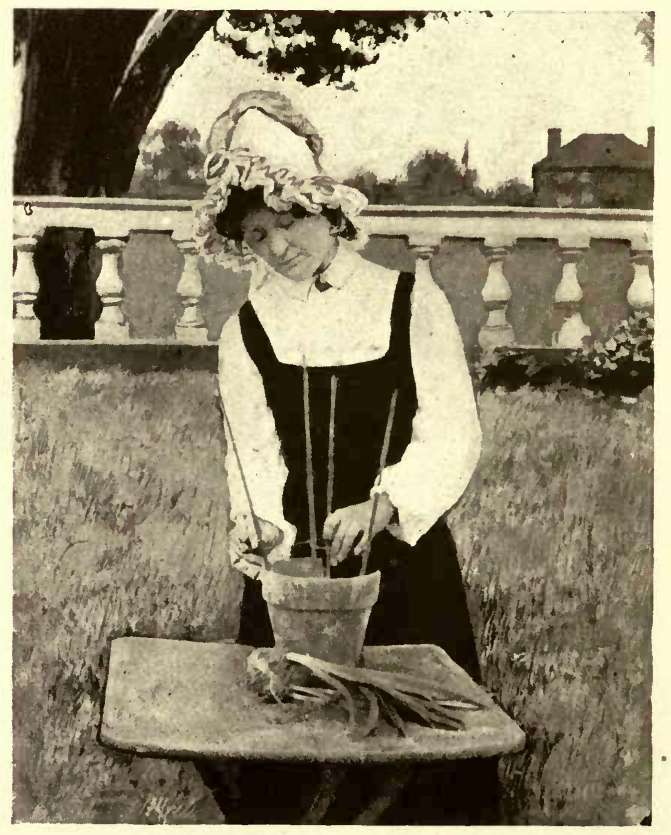

AN EASILY MADE CARNATION SUPPORT 
flower-pot, divided in halves, may be fitted around the cut, the bottom of the pot resting on a lower limb or other support, and filled with earth or sand kept constantly moist.

Cuttings liable to decay, as are some of the Cacti, may often be saved by tying them to a bit of wood and inserting that in the ground so that the end of the cutting just rests on the surface. In this way the air will reach and harden it so that a callus can form. Without the formation of the callus the sap escapes and the branch withers or decays. When the callus forms the imprisoned sap goes to the formation of roots. Some plants form more pronounced calluses than others-particularly the Gloxinia and Rose.

Layering is another form of rooting cuttings, and is especially valuable for Carnations, Honeysuckles, and plants whose branches grow near the ground or are supple enough to be bent down below its level. A cut should be made in the under side of a branch just below a joint, the cut portion brought down below the ground to insure moisture, and bent sufficiently to spread the cut somewhat, or it may be laid on the surface and a stone placed at the point of the cut. From a long branch like the Honeysuckle a number of cuttings may be started at once by notching the branch in several places and pegging it down, making the ground higher between each notch that there may be sufficient bend to the branch to keep the cut open. 


\section{Chapter EIGHT \\ 珀ouge=plants J Jrom Seros}

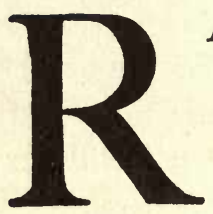

AISING house-plants from seed is a most fascinating work, and it is also the most economical way of obtaining a number of choice plants, as a packet of seeds may be purchased for the price of a single plant. A package of Geranium seed may give a dozen plants, while a packet of Gloxinias or Cinerarias may give a hundred or more-the fine seed germinating more freely than the large.

Mixed seeds also give a variety, no two plants being identical in bloom, and, what is most important, seedlings always bloom, while plants from cuttings are often stubborn in this respect and sometimes refuse to bloom at all, owing probably to the check received at propagation. A cutting taken from a vigorous plant, rooting quickly, and continuing to grow, is quite certain to bloom-while the reverse is the case with one slow to root and slow to start into growth after rooting. The seedling, meeting with no check, blossoms in the natural course, and it has the ad- 
vantage of growing from the start in the same atmospheric conditions, and does not suffer the violent change from the moist, warm air of the greenhouse into the dryer, more uneven temperature of the livingroom.

By sowing seed one obtains a number of plants with the same season of bloom, making a finer appearance than mixed plants blooming at different times. A half dozen Cinerarias or Calceolarias in full bloom is a sight to gladden the heart of the gardener.

In giving the following cultural details I have selected those seeds which are always carried in stock and may be depended upon to give good results in the hands of the amateur. Unless some one particular colour or marking is desired it is better to purchase the mixed seed-selecting always the finest, or "extra choice mixed," which will also be the highest priced. Never buy cheap seed for house-plants. Exception may, perhaps, be made in the case of Primroses, which are more inclined to come true, and it is, for this reason, better to purchase any particular colours one may wish in separate packets. Some seedsmen now put up expensive seeds in whole and half-sized packets, and the half packets will usually give all the plants needed of one kind. The mystery of tint and colour, only to be revealed at blossom time, is one of the greatest charms of growing mixed seedlings.

The Abutilons, or Flowering Maples, if set going any time before April will flower the same season. 
Start in the house in flats, and when large enough to handle transplant into tiny pots in a hotbed or sunny window and grow on until time to plant in the open ground, shifting as required. They may also be started in the hotbed, or in a protected bed in the open ground when the trees are in bloom. Set from one to two feet apart, according as a close hedge or fine specimen plants are required. The new California Abutilons present a great diversity of form and colour - there are beautiful drooping bells, gay little parachutes, flowers crinkled like crape or shining like satin, some so full as to appear double. They should be cultivated frequently if grown in the open ground and potted before the nights become cold, as a chill is often as harmful as frost, and plants so exposed are likely to lose their foliage. Plants intended for winter blooming should be lifted while the days and nights are still warm.

Asparagus plumosus nanus and A. Sprengeri (emerald feather) may be started any time in the late winter or early spring. The seeds are large and should be planted in rows an inch apart each way, pressing them into the soil a quarter of an inch and covering them over. They germinate in about twentyone days, and require no especial care other than to be kept moist and fairly warm. When an inch high transplant to thumb-pots, using the fine compost. Shift as often as necessary; all Asparagus-especially the Sprengeri-are greatly benefited by frequent re- 
potting. Spray frequently, keep moist always, and give liquid manure once a week while growing.

A. Sprengeri grows rapidly and is the most easily managed of all varieties. It needs, however, abundant root room, and where that is restricted must be given some kind of plant-food. It is the plant most used for hanging-baskets. A basket of three twoyear-old seedlings is a thing of beauty, throwing off wonderful fronds-even in the dry air of a sittingroom heated with a coal-stove. They should be given a chance to rest during the summer by setting in a cool, shady place, watering sparingly. When the plant shows signs of renewed growth repot, giving a larger pot if necessary, or, if two or three plants have been growing in one basket they may be separated and given more room. An elongated tuber is formed on the roots, which stores nourishment-like the nodules on the Clematis and Clover roots. It is useless for propagating purposes, and should not be disturbed. A basket or a pot on a bracket or pedestal is the only way in which to grow A. Sprengeri successfully, while A. plumosus nanus succeeds best in deep pots, as it sends its roots far down, often pushing its crown well above the soil in this way. A. plumosus sends out fronds several feet long, and is best adapted for growing on strings. A deep pot on a north or east window-sill suits it well, provided it is not too cool, and fine spool-wire makes a neat support and is almost invisible. 
The seeds of Rex and other Begonias are so fine as to look like dust. They should be sown on the surface of the soil, in flats in the house, in February or March, and an even temperature maintained. They germinate in eight or ten days, and the greatest care is required to keep the tender seedlings from damping off or drying out. The tiny plants appear first as a vague green bloom on the face of the soil, and a magnifying glass is necessary to show that each infinitesimal green point is possessed of a pair of leaves. From this time on it is a delight to watch the development of character in the leaf-quite tiny plants showing different markings. I have never raised two Rex Begonias exactly alike. When the little plants are large enough to handle prick them out into other flats, setting them an inch apart each way. When an inch high put into two-inch pots of leaf-mould, and plunge the pots in a pan of wet sand in a cool, north window where bulbs are growing, if possible, as the constant evaporation from these keeps the air moist. This is an important consideration in the culture of Begonias, and in winter water should be kept on stove, radiator or register to supply moisture. Among the fine bedding, fibrousrooted Begonias the new Vulcan, a fiery scarlet; Vernon, a deep red; Erfordii, a soft pink, and the dwarf Bijou are the best. By'starting these during January and February in flats in the house they may be bedded out in early summer. If planted in the house in January, transplanted to flats, and thence to the hot- 
bed when it is emptied after the 2oth of May, and partly shaded, they will be fine, robust plants by August, and may be used to replace the Pansies when it is not desired to carry these through the summer. If one has a sufficient number of pots, pot and plunge in the hotbed and they will not be set back by transplanting, but they must be plunged to the rim. They should be shifted when necessary, duly mulched, and not allowed to dry out.

Nothing finer than the tuberous Begonias can be desired either for bedding or for pot culture. The single are perhaps showier for bedding, but the double are handsomer for pot culture. They do admirably bedded out in a shady corner, or in pots in the sandbox. Peat, or a compost of two parts loam, two parts leaf-mould, and one part each of sand and old, wellrotted manure suits all varieties of Begonias. In setting out the tuberous Begonia it is well to mulch the bed with lawn clippings. Water thoroughly once a day, and, if very dry, or at all exposed to the sun, twice a day. So really wonderful are their blossoms, and so long and freely do they bloom, that they well repay a little extra care and protection. When frosty nights come the tuberous Begonias must be lifted, potted and kept indoors until they have completed their season of growth. Then water should be gradually cut off and the pots stored away in a dark, warm closet until spring, or if there are too many Begonias to pot they may be ripened off at once by putting on a 
tray of damp earth with the roots covered, and allowing them to dry gradually. When dry the tubers may be removed, wrapped separately in tissue-paper and stored in a dry, fairly warm place-a shelf in a closet or a drawer.

Probably no greenhouse flower is as little known or repays acquaintance as royally as the Calceolaria. Of infinite variety, its showy purse-shaped flowers range from a rare pure white through all the shades of pale lemon, orange, and scarlet to a deep, rich, velvety cardinal. It is one of the most easily cultivated of house-plants. The seed is fine like the Begonia, is handled in the same way, and germinates in eight or ten days. Shift as often as the pot fills with roots, using a size larger each time and disturbing the roots as little as possible. Rather more loam than leafmould is used in potting them. Keep in an east window in winter, where there is good morning sunlight and a temperature of at least 60 degrees. The air should be kept moist, either from blossoming bulbs or dishes of water on the stove. In a dry atmosphere it is liable to attacks of red spider, which greatly mar the foliage. The remedy or preventive measure is fresh air and moisture. Keep the soil moist but not wet. When the flower-buds appear slightly increase the supply of water and give a little manure once a week. The large felty leaves grow so thick and close that when the buds appear, to prevent injury from lack of light it may be necessary to remove a few leaves. If kept 
growing vigorously and shifted frequently, plants should be in five-inch pots by February and coming into bloom. When in full bloom it is well to remove to a cool room, where the blossoms will last for weeks. Cuttings may be taken when they are through blooming, but I think it best to begin afresh each year with seed.

Cinerarias make fine, large plants, as broad as they are high, their rich, velvety leaves showing on the under side wonderful colourings of green and lavender, purple and plum. The large heads of single daisylike flowers show many shades of white, lavender, crimson, purple, and maroon. Most of the varieties have a dark eye and are sharply margined with some contrasting color. The seed is fine and is simply pressed into the soil. It germinates in from five to seven days, and requires little heat. As the plants are rather difficult to carry through the hot weather it is better to defer sowing until August. Their growth is rapid if given a cool, moist atmosphere, but a draught is most injurious and care must be taken never to overwater them. They like a moist, but never wet, soil, frequently stirred when there is any sign of damping off. They may be carried through an unusually hot spell in a cool north or east cellar window, always avoiding draughts. In winter an east window suits them best, with abundant room to develop their leaves. They are an exceedingly ornamental plant even without the flowers. The shady side of the sand-box is the best 
place for them in summer. They need frequent shifting, and by winter should be in five-inch pots. After the buds appear give liquid manure once a week. The utmost care must be taken to guard against aphides or green plant-lice, which are absolutely fatal if allowed to gain any foothold. The prevention is plenty of fresh air and tobacco-dust sprinkled on the leaves, which mars their beauty. The remedy-dipping in water heated to about 135 degrees, or brushing off the lice and killing them.

Carnations are the most easily grown of all desirable house-plants. If planted in drills in the hotbed in April, or in the open ground when the trees are in leaf, they will bloom in about four months. For outdoor blooming the Marguerite Carnations are usually selected, and the Giant of California is a new and choice variety of this popular strain. The seed is sown an eighth of an inch deep, the plants appearing in from five to seven days. When large enough to handle transplant into fresh rows in hotbed or flats, setting them an inch or two apart each way. When they are two or three inches high prick off into pots filled with three parts good loam and one of leafmould and plunge back into the hotbed. When the weather is warm enough set them in well-prepared beds of loam, enriched with a liberal quantity of wellrotted manure, planting them a foot apart each way. Cultivate frequently during summer to keep them free from weeds. A little soot and ashes added to the soil 
between the rows will heighten the colour of flowers and foliage and add stiffness to the flower-stems. The ashes will also counteract the tendency to burst the calyx, so troublesome in the Carnation. Plants intended for winter blooming should have all the buds removed during the summer, up to the first of September.

Only a few flowers will be obtained in the open ground the first year, but if the plants are protected during the winter they will bloom freely the second season. While blooming no seed should be allowed to form, and if size and quality are desired more than profusion of bloom, all but the terminal buds on each stalk should be removed. This is the method employed by florists to produce their long-stemmed beauties. Dig in the second summer a little old manure between the rows and sprinkle ashes there. A mulch of two or three inches of lawn clippings between the plants will hold the moisture so that cultivation will not be necessary. Fresh Carnation seed should be sown each spring, that there may always be blossoming plants and the bed made perpetual. Carnations will not stand the second winter, hence the need of young plants to renew the bed.

If it is desired to perpetuate any variety cuttings may be taken, or the plants may be increased by layering. Branches from each plant may be pegged down between the rows, equal distances apart, severed from the old plants when sufficiently established, and al- 
lowed to remain when the old plants are removed in the fall or following spring. The bed will, in this way, perpetuate itself; but cuttings from the same plants deteriorate in two or three years, and fresh seed should be sown every two years at least.

In growing winter Carnations for the house shift them as often as the growth of the plant requires, using three parts loam, one part leaf-mould, and one part each of sharp sand and old manure. When ready to bloom they should be in five- or six-inch pots. They require an atmosphere cooler than that of the ordinary living-room. A south window away from direct fire, where the temperature stands at 50 or 55 degrees, is best. Water thoroughly, but allow the soil to nearly dry out before watering again. If possible sprinkle the foliage every day and watch carefully for green $\mathrm{fly}$ and red spider; though there is less danger of their appearance in a cool room than in the hot, dry air of the living-room. When the flower-stalks appear they will need support, which may be supplied by placing three or four sticks or cat-tails at the side of the pot and twisting strings around them, back and forth, forming a frame around the plant. There is an excellent Carnation frame on the market, costing a few cents, which is similar but much neater. Stakes thrust into the ground near the crown of a plant are apt to injure it, and must be used carefully if at all; the finer the point on the stake the less damage done. Should green lice or flies appear syringe the plants 
with tobacco tea, or fumigate with tobacco, leaving them in the smoke long enough to insure success. Or the plant may be dipped in hot water at about 130 degrees; this will kill all insects or eggs.

Cyperus, or Umbrella-plant, may be easily raised from cuttings, but it is sometimes desirable to have a number of plants for aquatic gardening, and growing from seed is an economy. The seeds should be sown in flats and kept warm; they germinate in about ten days, coming up very freely. As many as three hundred plants have been secured from one packet. Prick the seedlings out into larger flats as soon as they are big enough to handle, and when two or three inches high pot them off into two- or three-inch pots of muck, plunging into wet sand and keeping constantly moist. Shift them as the pots fill with roots, and by the time the plants are in four-inch pots the water should be kept standing in the saucer all the time. When they attain proper size they should be grown in a jardinière or other vessel holding water, or else the pot in which they grow should be plunged in water. The Cyperus, being a semi-aquatic plant, cannot have too much water; the lack is quickly shown by the leaf-tips turning brown. Two plants kept fairly wet in pots, but plainly suffering, so were plunged into a lily-tank; in a few days the roots had pressed to the surface in search of water, and hung, a perfect fringe, over the edge of the pots. The effect on the tops was as pronounced-the crown quickly sending up lush green 
umbrellas in striking contrast to the discolouration of the original plants. There are two varieties of the Umbrella-plant-a dwarf, growing not more than eighteen inches high, and a tall variety growing three or four feet; the former is prettier for table decorations, while the latter is more effective for pedestals in halls and drawing-rooms. Remove all weak or spindly umbrellas and all discoloured ones; it is also well to remove the flowers, as seeding injures the plant.

Cyclamen may be started in flats or in a cool hotbed from January to March, pressing the seed into the soil about twice their depth. They must be kept moist, not wet, all the time. They do not require as much heat as the Calceolaria, but the temperature must be kept as even as possible. The seed germinates in from two to four weeks, according to its vitality. It is best to start them in large flats and let them grow on undisturbed. About the last of May remove them to a cold-frame on the east side of the house, disturbing the roots as little as possible, and setting the plants about eight inches apart each way. Keep the soil moist and mellow by frequent cultivation, or by mulching it with sphagnum moss or lawn clippings. When the plants have attained some size give weak liquid manure once a week, pouring it in a shallow trench between the rows, that it may not touch the bulbs or foliage. Treated in this way they should be ready to bloom by winter; if grown in pots they will not bloom until the second season. When cold 
weather comes lift the plants and put in four- or fiveinch pots, according to size, using good garden loam and one-fourth the quantity of old, well-rotted manure. They should be grown in a cool east room and syringed daily.

In the spring after blooming withhold water gradually, giving no more than will keep the roots from drying out, and set them in a cool, shady place during the summer - the rear of the sand-box is best, where other growths will protect them from the sun. In continuous wet weather they should be turned on their sides or otherwise protected from extreme moisture. When they show an inclination to grow again, if they are in large enough pots, remove as much of the top-soil as possible without disturbing the roots, and replace it with fresh, rich earth and old manure. If the plants are crowded with roots remove them into pots one or two sizes larger. Give them a good watering and set in a somewhat lighter and warmer position. Cyclamen bulbs, like the Amaryllis, should not be allowed to dry out entirely, as this destroys the roots, and when the top growth starts in advance of the root growth, as is usual, the plant will die from insufficient nourishment. Florists frequently send out dry bulbs with flower-buds half an inch long and no sign of roots; such bulbs rarely amount to anything. When obliged to start a dry bulb, it is better to sink it half way in the soil and cover with sphagnum moss. Set it in a dry, cool place, and examine it from time 
to time that it may not be kept back longer than necessary. The starting of leaves is a fair indication of root growth, as the premature growth is usually of buds.

Geraniums are as easily raised as Carnations-indeed, it seems only necessary to put them in the ground and await results. In the spring sow the seed in drills in hotbeds or flats, covering with an eighth of an inch of soil. The plants should appear in from ten to fifteen days, and if they do not stand too closely may be allowed to grow on until they have two or three leaves. If mixed seeds are sown of the fancy-leaved, the scented, the zonale and the Lady Washington, the development of the several kinds will afford a fascinating study.

Care should be taken to save the more delicate-looking seedlings, as these will give the choicest varieties; the more robust plants among the zonales indicate a retrogression toward the original type, which has scarlet blooms. All choice new Geraniums are produced by seeds from hybridised flowers. Pot off the last of May in three-inch pots, using good garden loam and well-rotted manure. Pot them rather firmly and plunge into the sand-box in full sunshine. Water thoroughly and allow the soil to become dry before watering again; this tends to harden the new growth and makes the plants stocky. Nip out the top of the plants, forcing them to break or make new branches near the ground. The nearer the ground a Geranium 
branches the better plant it will make. Pinch off the shoots as they appear, allowing them to grow only three or four inches long. Remove all buds that appear before fall and shift to larger pots if needed, though Geraniums do not need as much pot room when blooming as many other flowers. Give liquid manure once a week after the buds appear-before that time the use of fertilisers encourages the production of foliage rather than of flowers.

Zonales should bloom by February and Pelargoniums by March or April the first year. They should be watered more freely when in bloom. Geraniums should be grown close to the glass to give best results. In prolonged cloudy weather the buds will blast and the new growth look sickly in spite of all care. Pelargoniums are very satisfactory when raised from seed, showing great diversity of colour and markings. When they have finished blooming in the spring cut them back freely, using the cuttings for new plants. The old plants should be set in the shade to rest and watered sparingly. At the end of that time they may be brought into the sunlight or plunged into open ground and encouraged to grow freely. Removing a portion of the leaves at this time-every other one, for instance-will cause new shoots to break at the axils of the leaves, and every new shoot means new blossom points. By the middle of September the plants should be lifted, cut back to the point where the wood begins to harden, and given a warm, sunny 
window. Cuttings started in spring, if shifted, kept growing and pinched back occasionally, should be in splendid condition for early spring blooming. In growing Geraniums never lose sight of the fact that stocky, many-branched plants give flowers in abundance; tall, spindly plants the reverse. A Geranium should always be as broad as it is high to be at its best. Ivy Geraniums need extra care to keep them low and stocky. Water sparingly and give abundant sunshine if you wish these to bloom.

Geranium seeds come up very irregularly, so that it is well not to disturb the ground for some time after the proper season of germination has passed. In this way many extra plants are secured.

\section{Gloxinias}

IKE all fine seeds the Gloxinias often give a surprising number of plants from a single packet. The seed is sown on the surface of small flats in the house and the plants appear in about ten days. They are very tender at first and must be protected from undue heat, moisture, cold or draughts. They may be potted when large enough and plunged in the shady side of the sand-box, in a cold-frame, on the east side of the house, or in a shady corner in the open ground, where they will be protected from the sun during the hottest part of the day. Keep the soil constantly moist; a light mulch of sphagnum moss or lawn clip- 
pings will keep it in proper condition. Avoid wetting the foliage and as far as possible touching it. The stems of both leaf and blossom are very brittle and the slightest blow may deprive one of a cherished blossom. For this reason I like to grow them by themselves and use a mulch instead of cultivation. So much of the beauty of the plant depends upon the perfection of the foliage that every effort should be made to preserve it. In setting or potting Gloxinias the crown of the bulb should be above the earth, the soil should slope to the rim of the pot, that no water may settle about the crown and rot it. The plants may remain in the hotbed or other quarters until the approach of frost, when they must be shifted into larger pots and given a position in an east window with plenty of light. Gloxinias, if kept growing vigorously and shifted frequently, should bloom the following season. Some florists advise resting the bulb the first winter, but this, I think, is a mistake; the plant has done nothing to require a rest, nor has the bulb gained sufficient size to live without nourishment for any length of time, so that drying off is likely to result disastrously. After the Gloxinia has completed its period of bloom water should be gradually withheld and the foliage allowed to ripen. The bulbs may then be set away in their pots in a warm, dry place, until the following spring; or, if grown in hotbeds, they may be dried off by withholding water until the foliage ripens, when they may 
be lifted, wrapped in cotton-wool or tissue-paper, and stored in a dry, fairly warm place during the winter.

\section{Heliotropes}

RE more easily raised from seed than from cutA tings, which require special care. Several of the new varieties, like Lemoine's seedlings, give exceptionally large and early flowers, ranging in colour from pure white through all the shades of lavender, purple, and blue to deep indigo. If wanted for winter blooming the seed may be sown any time during the spring, but for bedding out it should be sown in February or March, and the plants duly potted off and plunged in a box of sand in a warm, sunny window, or a hotbed, until it is time to bed them out in the open ground. The compost should contain a large proportion of leaf-mould - three-fourths mould and one-fourth loam and sharp sand.

The seeds of Heliotrope must be kept merely moist, never wet and never allowed to dry out, or they will not sprout; keeping the soil just on the verge of drying out, yet never allowing it to do so, is the whole secret of starting Heliotrope from seeds. It is best to sow the seed in moist soil to avoid the necessity of watering afterward, as is done with other seeds; if the soil is just wet enough to be crumbly, neither wet nor sticky, and can be kept so, they will prosper. Cover the seed lightly with white sand and remove 


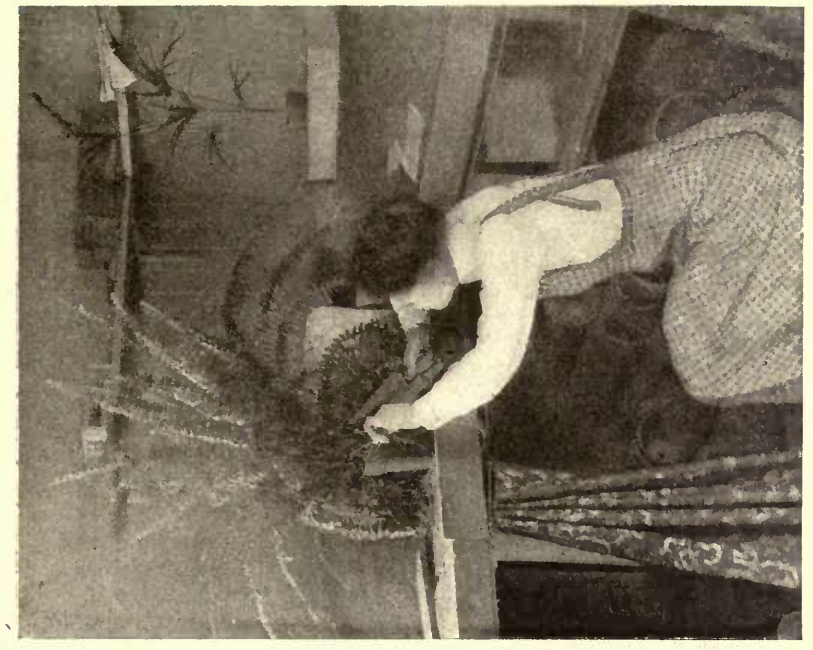

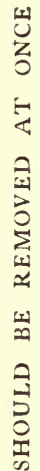

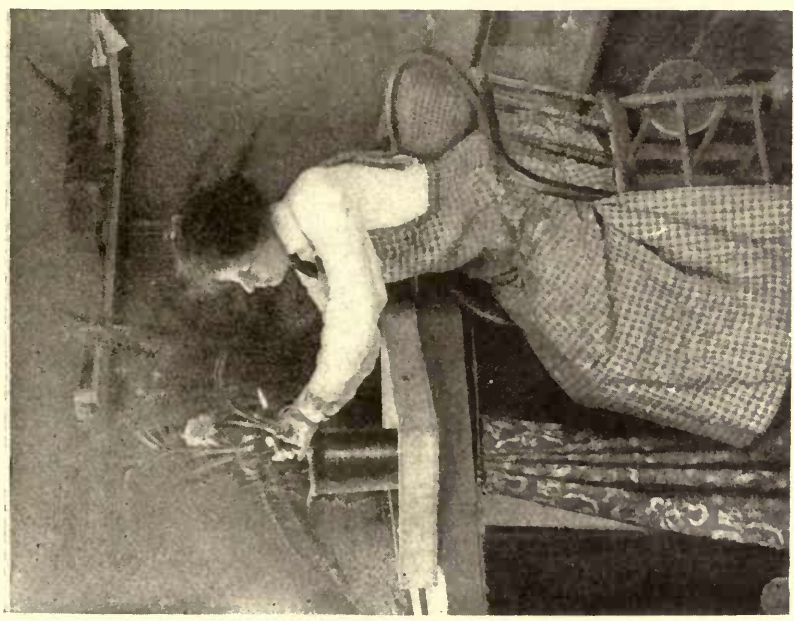

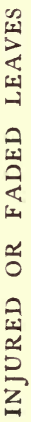




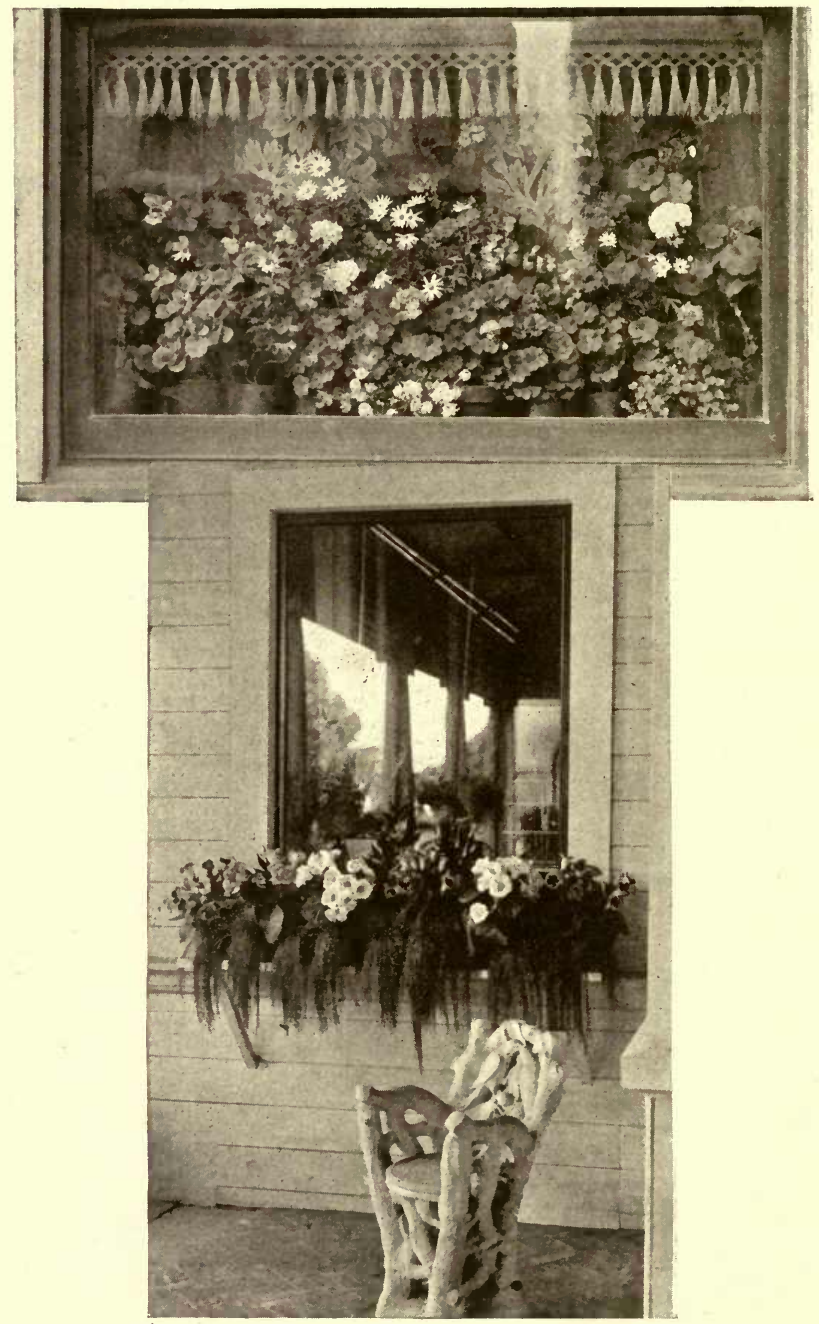

OUTSIDE WINDOW-BOXES 
the glass if any appreciable moisture appears-anything more than a fine mist. It germinates in from fifteen to twenty days, and the plants require no special care beyond good soil, warmth, and plenty of sunshine with frequent waterings. When grown as house-plants they should be showered once or twice a day to prevent the inroads of the red spider-their worst enemy.

There is no more desirable bedding plant than the Heliotrope, and the more freely it is cut by removing generous portions of stem with the blossom the more freely it will bloom. It is admirable for replacing Pansies and may be grown on in the hotbed until the Pansy's day is past. Where there is not enough Heliotrope for large bedding operations, purple Ageratum may be combined with the Heliotrope with excellent effect; this is a method often employed in the city parks, and when judiciously done one scarcely notices that the beds are not all Heliotrope. Plants may be taken up in the fall and cut back for winter blooming. Blossoms always form on the terminals of the branches.

\section{Lantanas}

A RE hard-wooded, shrubby plants, the leaves A more or less rough and prickly. The colours range from pure white through various shades of lemon to orange, red, a new bright scarlet, and the rosy lavender of the Weeping Lantana. The seed in 
its immature state is incased in a green pulp or berry, changing to blue as it ripens, and consists of a little nut with several kernels, so that one is sometimes surprised with two or more plants from what seems to be a single seed. The seed may be started in the house, or in the hotbed early in the spring; sowing in drills one-quarter of an inch deep. It germinates in from twelve to fifteen days, but soaking in warm water, for a few hours before planting, will hasten its appearance. They require about the same treatment as Geraniums, but should be shifted oftener and given plenty of water. As soon as the plants are four or five inches high transplant them to a tobacco pail, or some large wooden receptacle containing a compost of muck, loam, and old manure, or muck alone, and place in full morning sunshine, out of doors. Thus managed I have grown, from seed sown in March, plants that measured nine feet or more in circumference by September and were a mass of bloom all summer long, the blossoms defying all efforts at counting.

Grown in this way, with an abundance of roots and top room, rich soil, sun, and water, no better ornament could be desired for the porch or steps; but I do not think it a desirable plant for the house, as the hot, dry air causes it to drop its leaves, and it is almost sure to be attacked by the red spider. It is better to start fresh plants each spring and let them go then frost comes. 
Lantanas make fine hedgerows between house lots or for defining different portions of the grounds. They should be planted in rich ground two and onehalf feet apart.

The new Weeping Lantana is the most charming member of the family. It is of much more slender growth than the rest and inclined to be pendulous, or weeping. Its delightfully fragrant flowers are produced in round heads the size of a half-dollar at the axil of every leaf and show a lovely rosy-lilac hue. If planted in the open ground the Weeping Lantana quickly covers a considerable area, presenting a solid sheet of bloom throughout the summer. It will bloom freely in the house if given a warm, sunny window, abundant room, and showered daily to keep back the red spider, or dipped occasionally in hot water for that purpose. It must always have abundant root and top room and plenty of water.

\section{Petunias}

$P^{\text {ROBABLI no common flower of the garden }}$ has been so improved during the last few years as the Petunia. The small-flowered variety of a few years ago with its straggly habit and narrow range of colour-chiefly white and faded magenta-is now superseded by magnificently fringed and ruffled beauties in a wealth of colour, from purest white to glowing crimson, and a velvety purple that is almost black, 
with wonderfully veined and tinted throats and thick, stocky stems. It is difficult to realise that they are the same plants, plus a few generations of good living and culture.

The double Petunias are desirable for pots, vases, and bedding out, but I do not think they compare with such strains as Burpee's Defiance, the Giants of California, the Ruffled Giants, and the Miranda. Miranda, for example, is a rosy carmine merging into a brilliant scarlet in the throat-the nearest approach to a scarlet Petunia yet produced. The seed of double Petunias will yield a fair proportion of double flowers. The young plants of both the single and double varieties require great care at first, being very sensitive to hot sun or cold air. Once established, however, they will stand a great deal of both-more, indeed, than almost any other flower of this class. Plant them in flats in the house in March by pressing the seed into the soil without covering; keeping moist and warm until the seed germinates, usually from eight to ten days. When large enough to handle, prick off into larger flats and set them in a warm north or east window. When the leaves touch set them two or three inches apart each way in other flats and let them grow until it is time to place them in the open ground, hardening them gradually by exposure to more sun and air each day, and transplant with great care. If intended to replace the Pansies they may be set in the bed in June, the Pansies afford- 
ing them protection until they have attained some size. Set each little seedling on the north-east side of a Pansy plant, and by the time the Pansies have passed their zenith they will be ready to stand alone.

Always remove poor or inferior plants in order that the highest standard may be maintained; the finer varieties may be readily distinguished from the more common sorts by the stems and foliage; the latter having thin stems and small leaves, set rather far apart, while the stems of the fine varieties are very stocky; the leaves large, more or less crinkly, and set closely on the stem; the buds thick and compact, while those of the common type are long and thin. Petunias grow so rapidly that vacant places left by culling are soon filled. The finest specimens may be lifted for winter flowering. They will bloom freely in the house and often show a richer colour than when out of doors. They need considerable root room-any crowding of the roots, or starving of the plants being quickly shown in the deterioration of the flowers. Avoid chills and draughts. Give liquid manure and water freely, but do not let the soil get wet or sour. A little charcoal in the potting soil is an excellent corrective of this tendency. Always remove the flowers as they fade, thus prolonging the blooming season and increasing the beauty and size of the blossom. 


\section{Primroses}

R EQUIRE the same general treatment as other 1 house-plants. A good compost of leaf-mould, loam, and sand is best for the first few shiftings, manure being added as the plants attain size. Repeated shifting hastens blooming, while keeping the plants in small pots retards it. When ready to bloom they should be fine, large plants in five- or six-inch pots. They should blossom in November and, if well cared for, they will flower from that time on until spring. In potting the Primrose care must be taken to have the crown of the plant slightly above the surface of the soil and the soil lowest at the edge of the pot, that no water may settle around the crown and cause it to rot. When the buds appear give the plants diluted liquid manure once a week. As the leaves of Primroses are easily injured they should be placed where they will be subjected to as little handling as possible. Window brackets make an ideal place for them, as they can be turned and inspected without removal, and the large velvety leaves, drooping gracefully over the pot, will develop perfectly. Injured or faded leaves should be removed at once. A receptacle rather broad than deep gives opportunity for the best development. A hanging-basket, milkcrock with drainage hole, or jardinière with outlet will answer. Sufficient root room is particularly necessary in the case of old plants, as these have more 
divisions to the crown and therefore spread more. Primula obconica does better when grown in shallow dishes; a dish four inches deep and eight wide is much better than the usual flower-pot.

Florists start their Primroses each year from seed, but there is no reason why, if one has a choice plant, it should not be carried over to the second year, when, being larger, it will give more flowers. 


\section{Chapter NINE

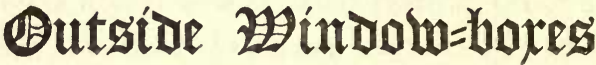

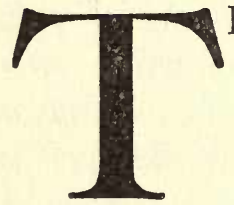

$\mathrm{HE}$ outside window-box is a thing of beauty if well cared for, a disfigurement if neglected. So greatly does it add to the cheerfulness and apparent size of the rooms under the windows of which it is placed that I should advise its use whenever practicable. One of my pleasantest recollections is a window-box full of Heliotrope under a sitting-room window, filling the room so full of perfume that going into it in the early morning was like stepping into a garden of fragrance.

Window-boxes do well in any window not shaded by porches, and the plants best suited to the light may be selected. Many plants too tender to bed out in the open ground may be trusted to the windowbox. Fuchsias, Ferns, Asparagus Sprengeri, A.tenuissimus, Ageratums, fancy-leaved Caladiums, and various tuberous-rooted Begonias, like the silver-spotted, known as Angel's Wing, are all lovely in the window-box. Rubra and most of the Begonias do admirably in a north window. For windows facing 


\section{Outstide 27indolu=bores}

the street, where effect is principally sought, bright Geraniums, Heliotropes, Coleus, Crotons, and simliar plants are preferable, provided there is sufficient sunshine to bring out all their rich colouring.

The fancy-leaved Caladiums may be used where bright effect is sought in a north window.

The boxes used for this purpose should be as ample as possible, the full length of the window-casing outside and at least a foot wide and deep. They should be made of inch boards, closely fitted together so that the sides shall not warp and allow the water to run through too freely, washing out and exhausting the soil. A hole may be made in the bottom at one end, and provided with a plug, for the escape of surplus water during continued rains. A piece of broken crock or other drainage must be placed over the hole on the inside of the box to prevent the earth working in and obstructing the free passage of water. The hot air of summer will shrink the earth away from the sides of the box, leaving a channel for the water to escape without properly soaking the soil; but if the surface of the soil is kept open, and the centre left a little lower than the sides, this will be prevented. A little experimenting will show just how much water is needed to wet the soil properly without letting it run away, and this amount should be used daily during dry weather. Only as many plants as will do well in the limited space of four square feet should be planted in the window-boxes. Five 
erect plants and three vines are enough for a box of that size, and even these may need attention before the season is over, especially if in south or west windows. North or east boxes will, usually, keep their contents fresh until frost; but a west or south light makes great demands upon the vitality of plants confined within the limited area, and it is a good plan to leave Geraniums and similar flowers in their pots, that they may be easily exchanged for others when they grow shabby, cutting back and repotting the old ones for winter blooming if removed not later than August.

A better plan is to have two boxes; starting one in the house in March, that it may be ready to place as soon as danger of frost is past; and the second in June, that it may be ready to replace the first when needed. For the latter the vines started in the house, or hotbed, in April will be available. Maurandya, Thunbergia, and the like, and many flowers from seed will have reached sufficient size to be used for the second box. Plants that have been carried over from another season, or purchased from the florist, will be necessary for the first boxes. There is no more beautiful vine for a window-box than the Maurandya; it drapes more gracefully than any other vine I know (unless it be the Wild Cucumber, which attaches itself to the window-screen in wreaths of exuberant bloom, drooping far below the window-box, and making a lovely background for scarlet Geraniums). Its only 


\section{Nine] Outgide 2mindolu=bores}

fault is that it will grow shabby before the season is over, when it had better be pulled up and replaced by a fresher vine that has been grown in a pot for the purpose and can be slipped into place without checking its growth.

Perhaps no plant is more satisfactory for a south or west window-box than a good Geranium-either the dark, rich vermilion of the S. A. Nutt, or the vivid scarlet of the Bruant. Both of these appear to better advantage when contrasted with white flowers. Camphor Geranium is excellent, being a freer bloomer than other white Geraniums, and the Giant White Antirrhinum is especially vivid. Double white Petunias and white Phlox Drummondi are also good. Purple Ageratums and Heliotrope are charming with scarlet and white. The large-flowered Ivy Geraniums - Souvenir de Charles Turner-are the best, and do finely in east and west window-boxes, while the variegated variety makes a lovely mass of pendent foliage for an east or north box. Trailing Fuchsia, Japanese Morning-glory, Glechoma, and Wild Cucumber all do well on the north side of the house. The following combinations may all be depended upon to give satisfactory results:

Southern Exposure.

$$
\text { No. I. }
$$

Bruant Geranium White Antirrhinum. S. A. Nutt Geranium (scarlet).

Heliotrope.

White Maurandya.
Heliotrope.

(cardinal).

White Maurandya.

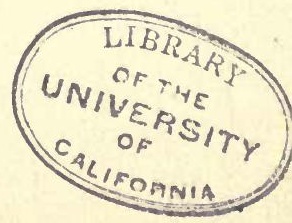


No. 2.

Jean Viaud Geranium (pink).

Dwarf blue Ageratum.

Mrs. J. M. Garr. Jean Viaud Dwarf blue Ageratum. (pink). Nepeta Glechoma. Souv. de Charles Turner. Nepeta Glechoma.

No. 3 .

Beaute Poitevine Ger. White Verbena. Madame Charlotte Ger. (salmon).

Weeping Lantana. (salmon).

Var. Ivy Ger. Joan of Arc. Ivy Ger. Joan of Arc.

No. 4 .

Dark Crotons. Dark Crotons. Dark Crotons. Adlumia. Light Crotons. Lotus Peliorhynchus.

No. 5 .

Light Crotons.

Dark Coleus. Trailing Abutilons.
Light Crotons.

Trailing Abutilons. Adlumia. Light Crotons.

No. 6.

East Window-box.

Scarlet Tuberous Begonia. White do. Scarlet Tuberous Begonia. White Tuberous Begonia. White Tuberous Begonia. White Thunbergia. Scarlet Nasturtium. White Thunbergia. 


\section{Nine] Outstare 2mindolm=boxes}

No. 7 。

Pink Justicia.

Heliotrope.

Pink Justicia.

White Maurandya. Solanum Jasminoides. White Maurandya.

No. 8.

Yellow Tuberous Begonia. Yellow Tuberous Begonia. Yellow

Tuberous Begonia.

White Tuberous Begonia. White Tuberous Begonia.

Yellow Thunbergia.

Yellow Thunbergia.

No. 9.

Pink Double Petunia. White Antirrhinum. Pink Double Petunia. Wild Cucumber。

No. 10.

Heliotrope.

Duke Zeppelin Begonia.

Solanum Jasminoides.

Manettia Vine. Solanum Jasminoides.

Heliotrope.

Heliotrope.

Duke Zeppelin Begonia.

No. II.

North Window-box.

Fancy Caladiums Fancy Caladiums Fancy Caladiums (dark). (dark). (dark).

Fancy Caladiums (light). Fancy Caladiums (light). Vinca Var.

Trailing Fuchsia.

Maurandya.

Vinca Var.

Trailing Fuchsia. 
No. 12.

Fuchsia Phenomenal. Begonia Angel's Wing. Fuchsia Phenomenal. Dwarf Ageratum. Ivy Geranium. Trailing Fuchsia.

Dwarf Ageratum.

No. 13.

Rubra Begonia. Asparagus Tenuissimus. Farfugium. Variegated Vinca.

Manettia Vine. Ivy Geranium.

No. 14 .

Asparagus Sprengeri.

Russellia Grandis.

Boston Fern. Cissus Discolour. Russellia Grandis.

Begonia Velutina. Feastii Begonia.

Variegated Vinca.

Nasturtiums make an attractive window-box, but need abundant root room, and not more than three plants should be put in a box having three other erect plants. Morning-glories, on the contrary, require but little room, and one may be put in each end of a north window-box and trained over the window. If strings are provided they will reach the roof by midsummer, blooming every step of the way; other vines may be grown in the front of the box. The Centrosema-when it can be persuaded to grow-is a charming vine for a north or east window, but it is a very shy plant, hard to get started, and refusing to grow in an uncongenial situation, though quite hardy when once established.

The best support for the window-box is the wooden bracket made by nailing to the side of the house, 


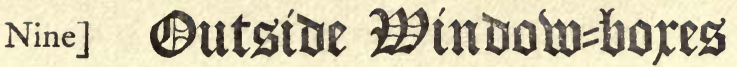

thirteen inches below the window-sill, a strip of inch stuff the length of the window-frame and three or four inches wide; on top of this and at right angles to it nail three similar strips of wood one foot long, the outer ends resting on strips of wood attached to the sill of the house; these last strips must have the ends bevelled sufficiently to fit snugly against the baseboards and the bottom of the horizontal pieces and be securely nailed together. If the measurements are carefully taken the box will slip into place, on the supports, just under the window-sill. Paint boxes and supports to match the house. Window-boxes may be kept in the cellar through the winter, or emptied, dried and stored in a dry place, according to their contents. Always empty and thoroughly scald the boxes before using.

In stocking window-boxes never put plants received by mail directly into them; they should be ordered early enough to pot and become established (the pots full of roots) by the time they are needed for the window-boxes, when they may be slipped into place without disturbing the roots or checking their growth. Placed at once in the boxes, in a sunny position, they would probably be lost.

Very fair window-boxes may be obtained at trifling expense by using the boxes in which grass scythes are packed, which may be purchased at the hardware store for five or ten cents apiece. These are not as wide nor as deep as one could wish, but have the ad- 
vantage of cheapness and availability. Preference should be given to those having close seams. If warped or open they must be tightened by driving in extra nails, or nailing thin strips of wood over the cracks on the inside. The longevity of the windowbox is greatly lengthened by keeping the windows above them-especially on the south and west sides of the house-open as much of the time as possible. If the sun beats on the glass of the closed window and is reflected on the plants, it is literally confining them between two fires and they cannot be expected to come through uninjured. Let the wind sweep through and over them and they will stand any reasonable amount of heat or moisture. This is the reason plants do better in the open than when placed against the side of a wall or building - the air must not only have free access, but pass beyond, carrying off noxious vapours and excess of moisture.

When there is garden room for their cultivation I do not approve of growing annuals in windowboxes; it is better to reserve these for choice plants; but when the window-box must be the only garden, and economy must be studied, very pretty boxes may be arranged with Sweet Alyssum; scarlet, white, or pink Phlox Drummondi; scarlet, pink, or white Verbenas; the various coloured Antirrhinums, Petunias, Nasturtiums, the blue Phacelia and Ageratums, Wild Cucumber, the finer foliaged fancy gourds, as Bryonopsis Coccinea Indica, and Abobra viridiflora. By 


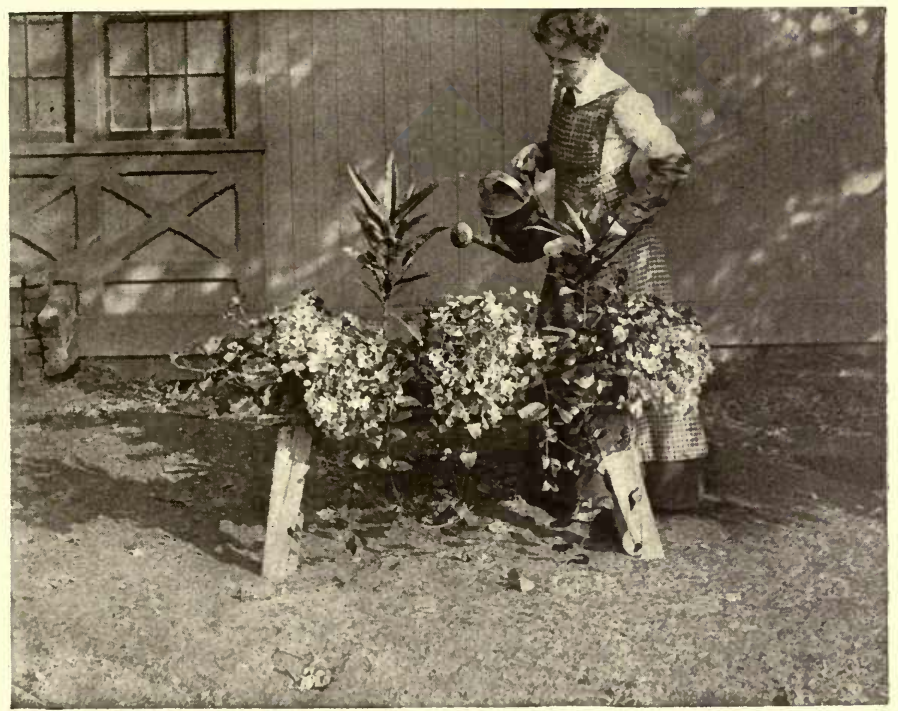

BOXES IN WHICH SCYTHES ARE PACKED MAKE VERY GOOD WINDOW-BOXES

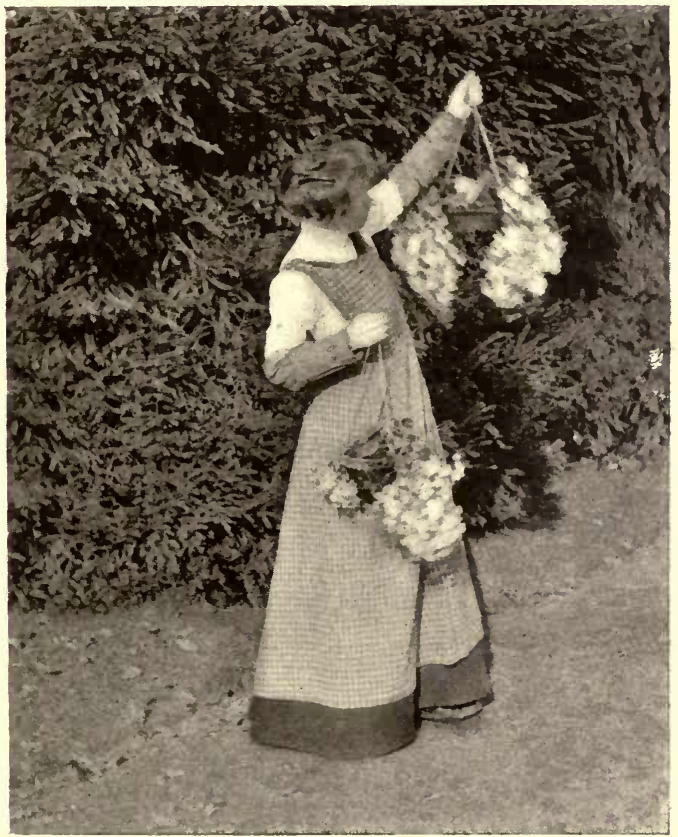

HANGING-BASKETS FOR WINDOWS 

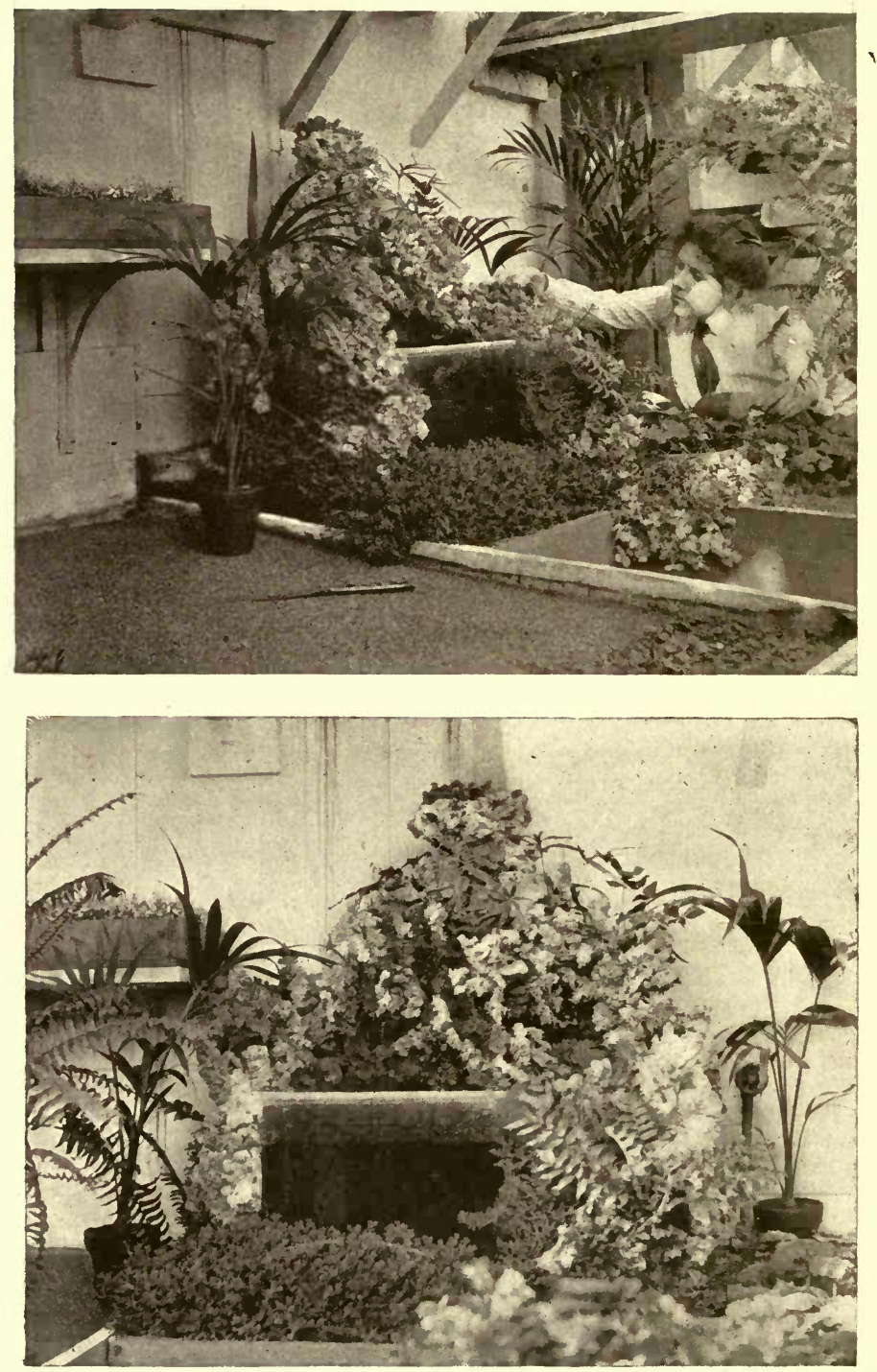

SMALL WATER GARDENS 
using the scythe boxes, and starting the plants from seed, very pretty boxes may be gotten up for from thirty-five to fifty cents a pair that will give as much pleasure as more expensive ones. The more flowers are cut from these boxes of annuals the more freely they will bloom, and no seeds should be allowed to form. A little liquid manure should be given all window-boxes-except those containing Begoniasonce a week during the summer, and all withered flowers and leaves promptly removed. Nip back weak, straggly growths and encourage the plants to grow stocky and the vines to branch freely. 


\section{Chapter TEN \\ Yartous Annuals from Serd}

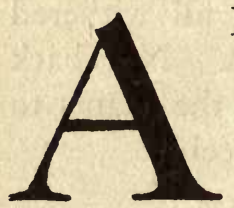

NTIRRHINUMS (Snapdragon). Of late much interest has been shown in the newer forms of this old-time favourite, and some fine new varieties have become popular for cut flowers. The Giant White and Queen of the North are most desirable for cut flowers, window-boxes, and vases; while Niobe-a beautiful half-dwarf variety of velvety maroon with white throat, Giant Yellow, Giant Crimson, and Firefly - a bright scarlet-are excellent for bedding.

Seed should be started early in hotbed or flats. Merely press it into the soil and cover with a paper until the plants appear, which should be in from eight to ten days. Transplant into rich soil where the plants are to remain, setting one foot apart each way. They are effective in rows with some taller plant, or vine, for a background. The tall, showy spikes are most striking against a background of green. The Antirrhinum is a half-hardy perennial, blooming the first season if seed is started early enough, and hardy 


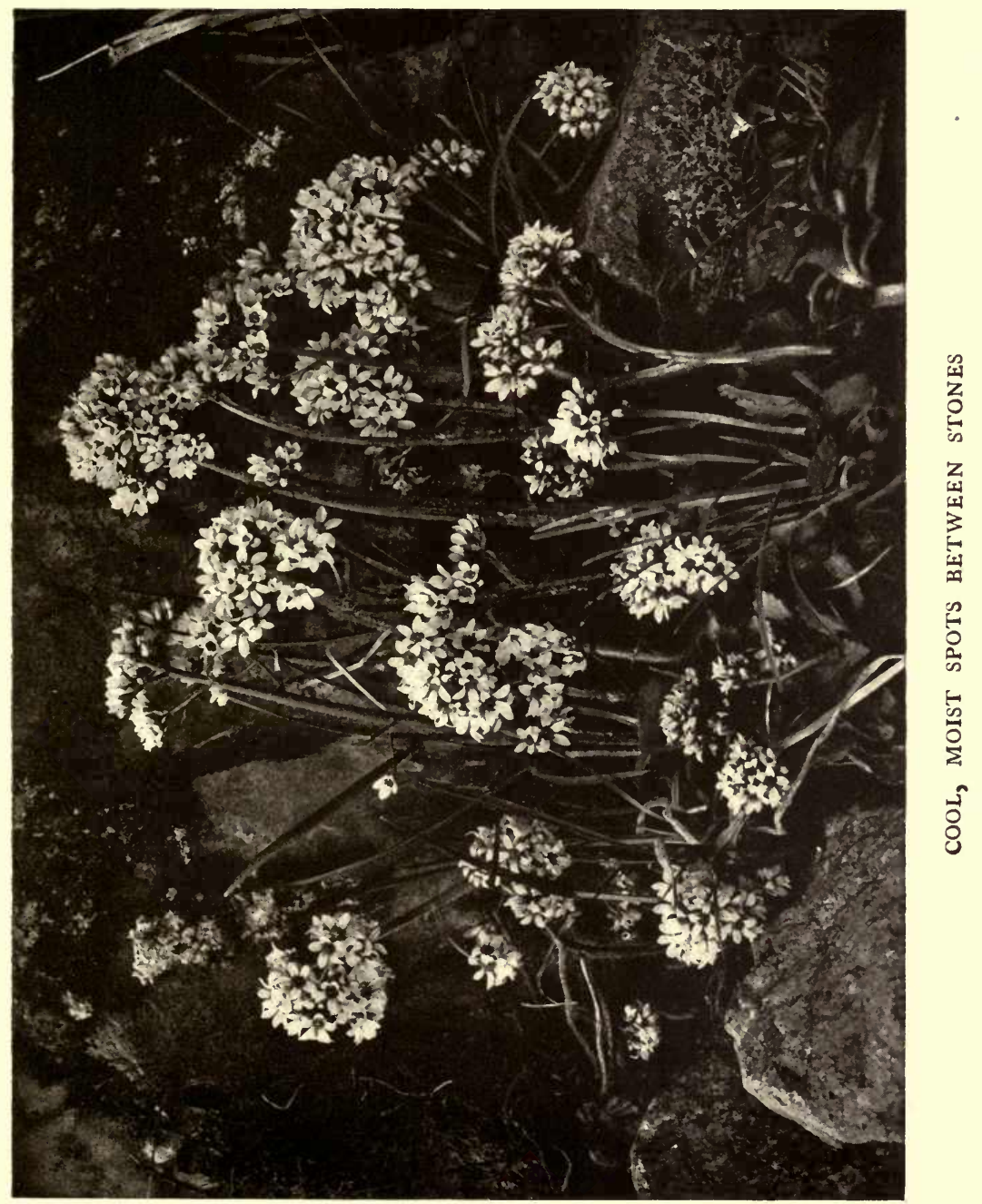




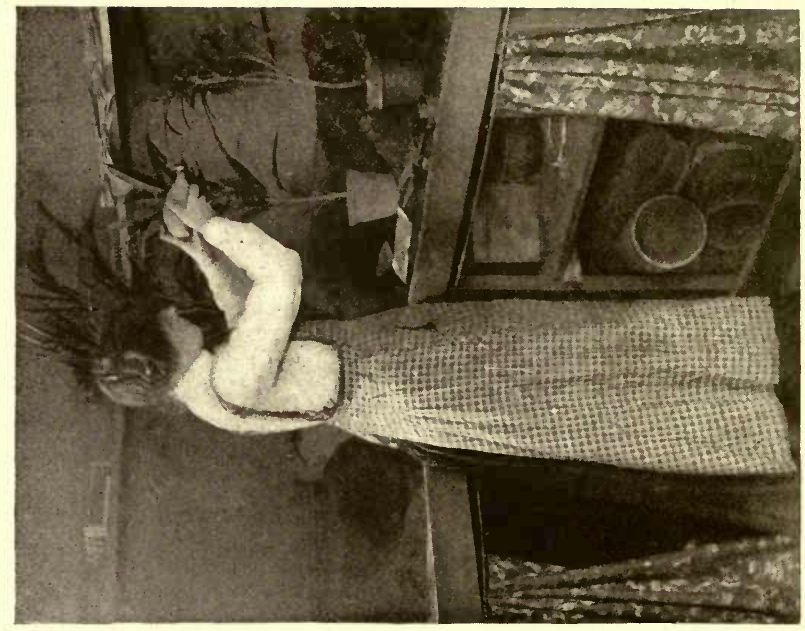



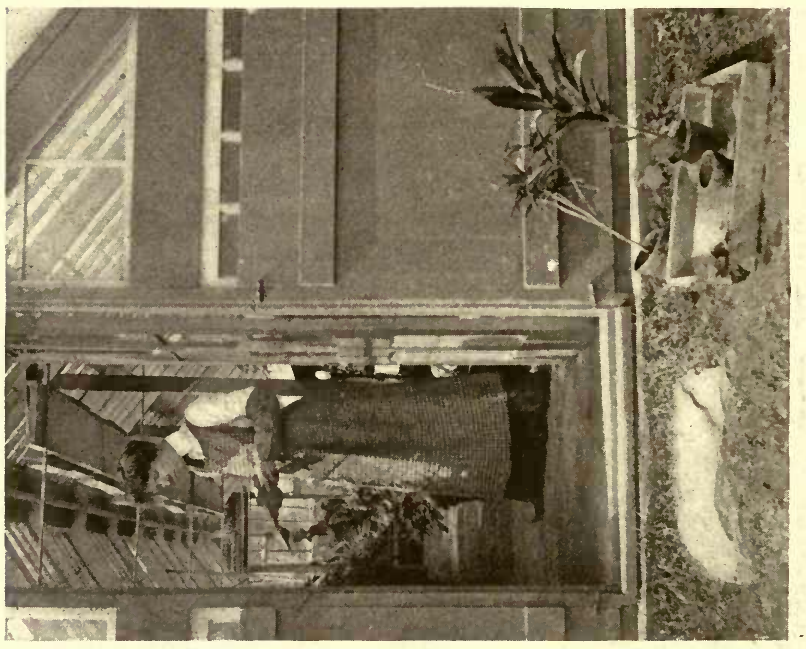

落 
at the North with good protection in winter. If a succession of flowers is desired, no seed should be allowed to form. Protect in winter with a mulch of leaves, evergreen boughs, or corn-stalks, as high-or higher -than the plants, or they may be pegged down and covered with evergreen boughs, or boards to shed the rain. Thus protected they will live through the winter and bloom heavily the following summer. Occasionally in favoured locations they will live through the winter unprotected, but this cannot be depended upon.

Antirrhinums are not particular as to soil or situation, provided they have plenty of water; rich loam or half loam and half leaf-mould suiting them equally well, and any exposure that affords a fair amount of sunshine.

Asters have come to be a recognised necessity of the fall garden, and there has been marked improvement in varieties during the past few years. Starting with the old-fashioned Aster of medium size and inferior colour, showing a marked yellow centre, the aim of the Aster specialist has been to eliminate the centre, enlarge the flower, and improve the colour and texture of the petal. Results are shown in such varieties as the Giant White Comet, the Bride, the Japanese Tassel Aster, Chrysanthemum Flowered, Peony, Perfection, and the wonderful Ostrich Feather.

With such an embarrassment of riches it is diff- 
cult to declare any one variety the finest, but for cut flowers and corsage wear nothing can excel the Chrysanthemum Flowered in white and pink.

The lasting quality of the flowers when cut is quite phenomenal. I have known them to keep fresh and sightly in water for a month, until the stems had entirely rotted away, leaving the flower uninjured. In arranging them for vases remove all leaves below the top of the vase, leaving clean stems, which should be thoroughly cleansed daily, and the ends clipped. A teaspoonful of charcoal added to the water in the vase will keep it sweet and retard decay.

Early planting of Asters is to be strongly recommended, as the early plants are not subject to the dreaded Aster disease or to attacks of the black beetle, which often destroy all the flowers of a late bed in a single day.

A teaspoonful of Paris green in the watering-pot, sprinkled on at night or very early in the morning, will usually rid the plants of their unwelcome guests, or they may be brushed off into a pan of water containing a small quantity of kerosene-which is fatal to them. They are sluggish, especially in the early morning, dropping to the ground when touched, and easily killed. The point is to take them in time, and the appearance of the first beetle should be the signal for active operations.

For early flowers the seed may be planted in the hotbed, flats, or cold-frame in March or April, cov- 


\section{Ten]

ering an eighth of an inch deep and keeping rather cool. They germinate in from five to seven days, and when the plants have attained their second pair of true leaves they should be transplanted, setting an inch or two apart in the flats or bed. Transplant again when the leaves close up the gaps between them, setting three or four inches apart according to their growth. If possible, transplant a third time, as this frequent moving serves to produce a great quantity of feeding roots, at the same time checking the top growth and making a stocky plant with stiff stems. Transplant when the weather is favourable into a well-prepared bed of sandy loam enriched with old manure, or a bed of woods earth. Set a foot apart each way, except in the case of the branching Asters, which should be at least two feet apart.

Sprinkle ashes freely, and as long as there is room to work between the rows cultivate once or twice a week. They may then be mulched with lawn clippings to keep down the weeds for the rest of the season. If they are planted in woods earth they will need only such cultivation as is necessary to keep down the weeds. Do not let them suffer for water at any period of their growth, and remove all flowers as they fade.

Ageratums (Floss Flower) are almost indispensable for edgings, window-boxes, vases, and for filling out beds of Heliotrope. The dwarf or Tom Thumb are the most desirable for edgings. Princess Caroline, 
Swanley Blue, and Little Dorrit are the best of this class in the blue or lavender shades. The white does not show a good, clear colour under a hot sun, and is therefore not desirable. For early plants sow in flats or in the hotbed early in spring. Later seed may be sown in the open ground when the trees are in bloom, and transplanted when large enough. Sow broadcast, covering the seed lightly and pressing it into the soil. They germinate in from three to five days, and may be grown on until time to transplant into permanent quarters. Though they may start somewhat spindly, they quickly regain their dwarf and stocky character in the open ground. Set plants from eight to ten inches apart in the row. If the flower heads are removed as fast as they fade plants will bloom from early June until cut down by frost.

Balsams (Lady Slipper), like Asters, are greatly benefited by frequent transplanting, and one at least they must have. Start seed early in the hotbed or flats, or later, when the trees are in bloom, in protected beds in the open ground. Transplant at least once in the seed-beds; twice, if possible. When danger of frost is past remove to beds of muck or marsh earth, setting from twelve to fifteen inches apart each way. Given plenty of room, the Balsam branches freely, and one well-developed specimen will give more and finer flowers than a half-dozen cramped specimens. In purchasing select the camellia-flowered 
varieties, as it does not pay to waste time with inferior kinds. Really fine Balsams are well worth cultivating, and are very effective in rows in front of taller plants. The double white and shell pink are valuable for floral designs for funerals and for other decorative work.

Probably no flower that has come into vogue of late years has won more popularity than the Cosmos - certainly for cut flowers nothing can surpass it in graceful beauty. The large pink and white Hibiscus, with a generous handful of long-stemmed pink, crimson, and white Cosmos, makes an ideal bouquet for a high glass vase. Placed in front of a large mirror the effect in form and colour is hardly surpassed by the choicest exotics. The graceful, fern-like foliage adds greatly to the beauty of a well-grown clump in the garden or lawn. They are at their best when seen against a background of darker green, a shower of crimson, pink, and white.

Only the early flowering varieties should be grown at the North, as the seasons are much too short for the giant or California varieties; though if one has room for both, the California may be grown as a background for the dwarf early flowering, as the foliage is much superior and the late flowers very fine. If started very early in flats in the house, pricked out into pots, shifted and grown on until time to set in the open ground, the season of bloom will be much advanced. 
Set out in rich garden soil and supply abundantly with water. Strong stakes must be provided, as the plants are very brittle at the joints, and a storm may do great damage if they are unsupported. An excellent way of growing them is to plant them in front of a wire fence or chicken netting on the side toward the prevailing wind, that they may be blown against, rather than away from their support, and the stalks and main branches tied to the wires with raphia, wool twine, or strips of cloth; thus protected there will be little danger of their being injured by rough winds.

If an occasional seed is allowed to form and selfsow there will come up very sturdy little plants the following spring, but fresh seed should be purchased every other year to insure against deterioration in size of blossom and quantity of bloom.

Columbine (the Aquilegia) seed may be sown in the open ground in the North when the trees are in leaf, or any time after May ioth. Cover the seedbed with a newspaper and keep moist until the plants are up, in ten to twelve days. Transplant when large enough to handle into fresh rows or, when they have attained sufficient size, into their permanent quarters. Planted in a row where they will have a background of green the effect is beautiful. One of the prettiest beds I remember was of mixed Columbine-pure white, rose, and lavender-in front of an old grey building, on which grew a delicate vine in its 


\section{Ter] Annuals from Serd}

first tender spring green. They had been moved the fall before from a bed where they attracted no particular attention, but in their new quarters they awoke to find themselves famous.

Dahlias are so easily raised from seed that it hardly seems worth while to bother with the tubers, unless one has exceptionally favourable conditions for storing them. Plants grown from seed, started early in the house or hotbed, will come into bloom quite as soon as those grown from tubers. Plant the seed in drills two inches apart, dropping an inch or more apart in the drills, and cover with one-eighth to onefourth inch of earth. The seed germinates in from five to seven days, and the little plants are quite robust from the start, though sensitive to cold and drought. When all danger of frost is past and the nights are warm transplant the Dahlias into beds of mellow soil heavily enriched with manure. Set three feet apart each way and cultivate thoroughly as long as there is room to work between the rows. Then mulch heavily with rough manure covered with lawn clippings. Water copiously during dry weather, showering the tops at night to counteract the effect of the dry air on the buds. Save waste water from kitchen and bath, and apply to their roots. This affords nourishment as well as moisture. When two feet high tie carefully to tall, stout stakes, which, to avoid injury to the tubers, would better be placed when the plants are set. Sprinkle soot and ashes between the plants and culti- 
vate it in. The finest flowers are produced by protecting with an awning of thin cotton cloth after the buds are fully grown-though this would only be desirable in the case of exhibition flowers. When several buds appear in one place remove all but the largest, as the difference in size will more than repay for the loss in number, besides there is danger of all blasting if allowed to remain.

If worms or beetles appear on the buds they should be sprayed with Paris-green solution-one teaspoonful of Paris green to three gallons of water. Should the borer-that pest of the Dahlia, Aster, and Cosmos-appear, pour the Paris-green mixture around the roots, soaking the soil to the depth of three or four inches. Examine the stock of the plant near the ground for the hole made by the borer. When found run a flexible wire up the stalk to destroy the worm and prevent further damage, and heap the earth above the wound. If brought up to a point above the wound, and kept moist, new roots will start, thus insuring the recovery of the plant. If one has previously been troubled with this worm it will be well to anticipate matters, and, commencing when the plants are a foot high, apply once a week a weak Paris-green solution; continue this until the plant is grown and the wood hardened near the ground.

The fine mixed double Dahlias, the Cactus and the magnificent single varieties, are all desirable for cut flowers and effective in garden rows; but for corsage 


\section{Ten] Ammuals from}

wear the last are best. It would be difficult to find a flower more beautiful than a vivid-coloured single Dahlia.

For the rockwork try English Daisies_pink, white, crimson, and striped. They do admirably in such a situation, digging their toes in between the stones, finding cool, moist spots, and holding their heads up in the hot sunshine. Start the seeds where they are to remain, or in a flat or cold-frame. The little plants appear in from five to seven days, and will need shade and moisture until they have become established. For beds that lie in partial shade they make beautiful borders, forming little rosettes of leaves that in the fall may be taken up and divided by pulling apart into as many plants are there are crowns; in this way one will, in a short time, secure a large bed or border. They should be protected in winter by a mulch of rough stable litter, evergreen boughs, or corn-stalks, and the bed raised to shed water.

The Hibiscus (Marshmallow) is a perennial deserving much more general cultivation. Even to flower lovers it seems quite unknown, and yet it is cheaply and easily raised from seed, and one of the hardiest of our garden perennials. There are three varieties hardy in the North-an immense pure white blossom with a velvety crimson eye, a pale pink or flesh colour, and a lovely bright pink. These three are hardy in the open ground without protection, but they will be stronger plants and bloom more freely 
if protected with a little rough litter and hilled to shed water.

There are several that may be treated as hardy annuals, and various tender perennials that must be kept in the house or greenhouse during winter. Among the first are Africanus, a large creamcoloured, brown-eyed variety; it is low-growing and effective in front of the tall, crimson-eyed sort, which with age attains a height of six or more feet.

Giant Yellow is a beautiful canary yellow with crimson throat, hardy as far north as St. Louis, but safer in the cellar above that latitude, and Coccinea, a tender perennial of a brilliant crimson. If started early all will give flowers the first season from seed, which may be sown in hotbeds or flats in February or March in drills one-fourth inch deep. They germinate in from five to seven days. Plant out in good garden soil at corn-planting time, setting the hardy varieties where they are to remain, as they do not bear transplanting well when they have attained any considerable size. Cultivate during the hot weather or mulch. A two-quart tin can, with holes on one side near the bottom, may be sunk in the ground and filled with water. This with the mulch will keep the earth cool and moist during the hottest weather. The plant is an herbaceous perennial, dying down to the ground in winter and coming up from the roots the following spring - rather late in May. 


\section{Ten] Ânnuals from Seld}

Plants increase in size and beauty each year, and a fiveor six-years clump is superb.

Cut off the stalks a few inches above the ground when killed by frost, but do not attempt to break them off or pull them up, as that will injure the crown of the large, fleshy roots and cause decay during the winter. The remainder of the stalk serves to mark the location of the plant. When they have grown to blooming size they should be tied to stout stakes. The large clumps have a tendency to spread at the roots, and a severe rain and wind storm may lay them prostrate. Make a support of two or three wooden hoops nailed to two or more stout stakes, the top hoop standing three feet above the ground. Place this over the plants in the spring and train them to grow up through the hoops.

For effective grouping, to fill in a corner, to serve as a screen to unsightly objects, to catch the eye and carry it on from point to point, there is no finer flower than the Hollyhock. The double flowers, of course, are more attractive at close range, but at a distance the single are rather more effective. Everyone who grows plants should find at least one corner for a big clump of this gorgeous flower.

The seeds should be sown in the spring, either where they are to remain or in a cold-frame; the location matters little so that favourable conditions of the soil are secured. Plants started after the seed ripens in the summer, even when protected by a cold-frame, 
do not make sufficient growth to endure a very severe winter. The new Alleghany Hollyhocks are hardier, and a fair proportion of plants from August-sown seeds may be expected to survive the winter. When the plants run up their blossom stalks the second season they must be securely staked to prevent injury by high winds. If the borer appears apply the Parisgreen solution about the roots. The Hollyhock is subject to attack very early in the season by a variety of red spider which feeds on out-of-door plants. The Paris-green solution may be used for this, or a kerosene emulsion, or the plants may simply be showered with hot water at about $145^{\circ}$. The remedy should be applied promptly. The Hollyhock blight is a fungous disease of a most destructive nature. Its ravages almost drove the Hollyhock out of our gardens some years ago. Infected plants should be burned. Though hardy the second year, they should be hilled up sufficiently to shed water and given a shelter of corn fodder or evergreen boughs during the winter.

When the trees are in bloom Nasturtiums may be planted in the open ground where they are to remain. They should have fairly rich soil and a sunny situation, as they will not bloom well in the shade. The dwarf varieties make very attractive borders for Canna beds, the colour and texture of the foliage harmonising better with the Canna than that of the Coleus and many other plants commonly 


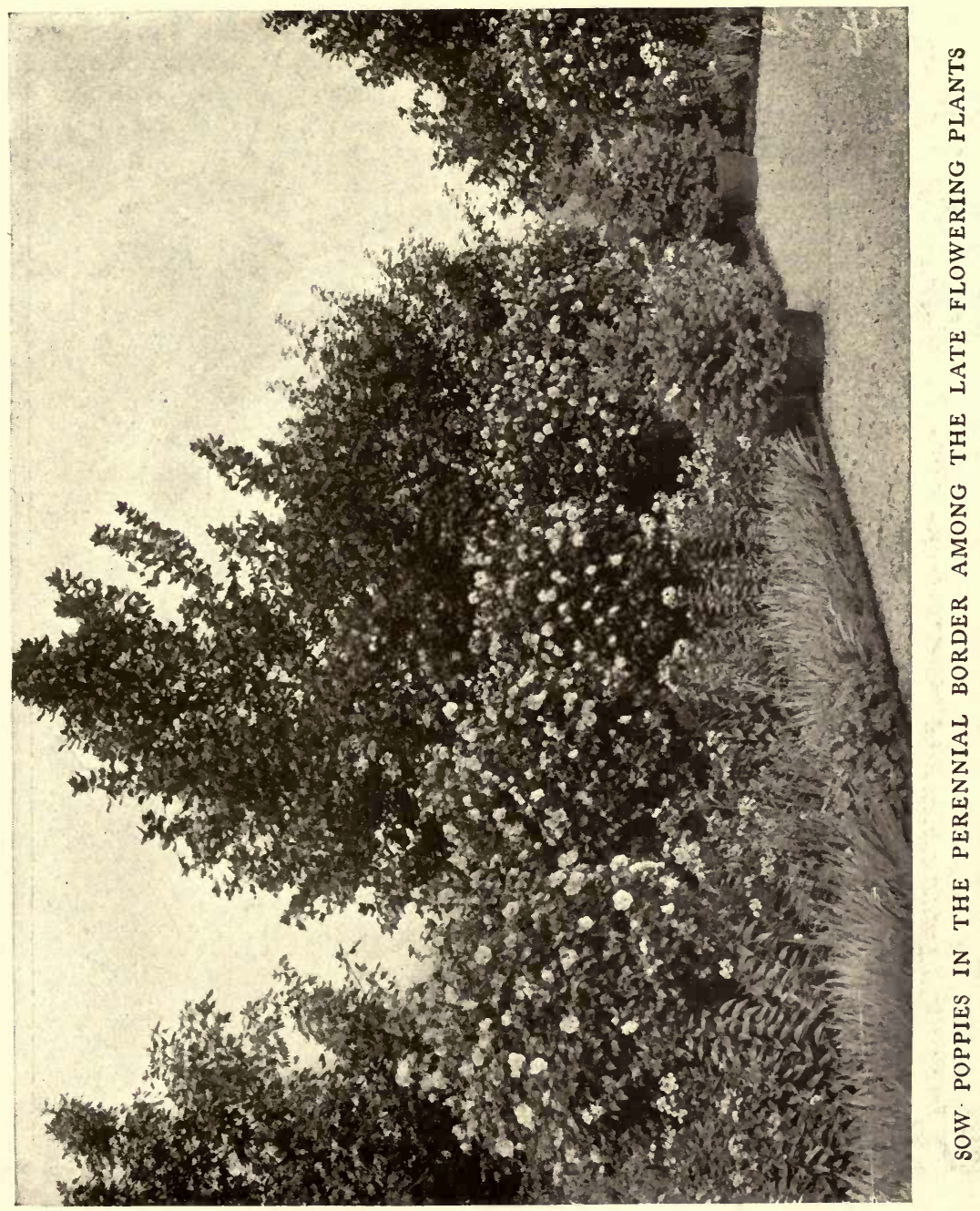




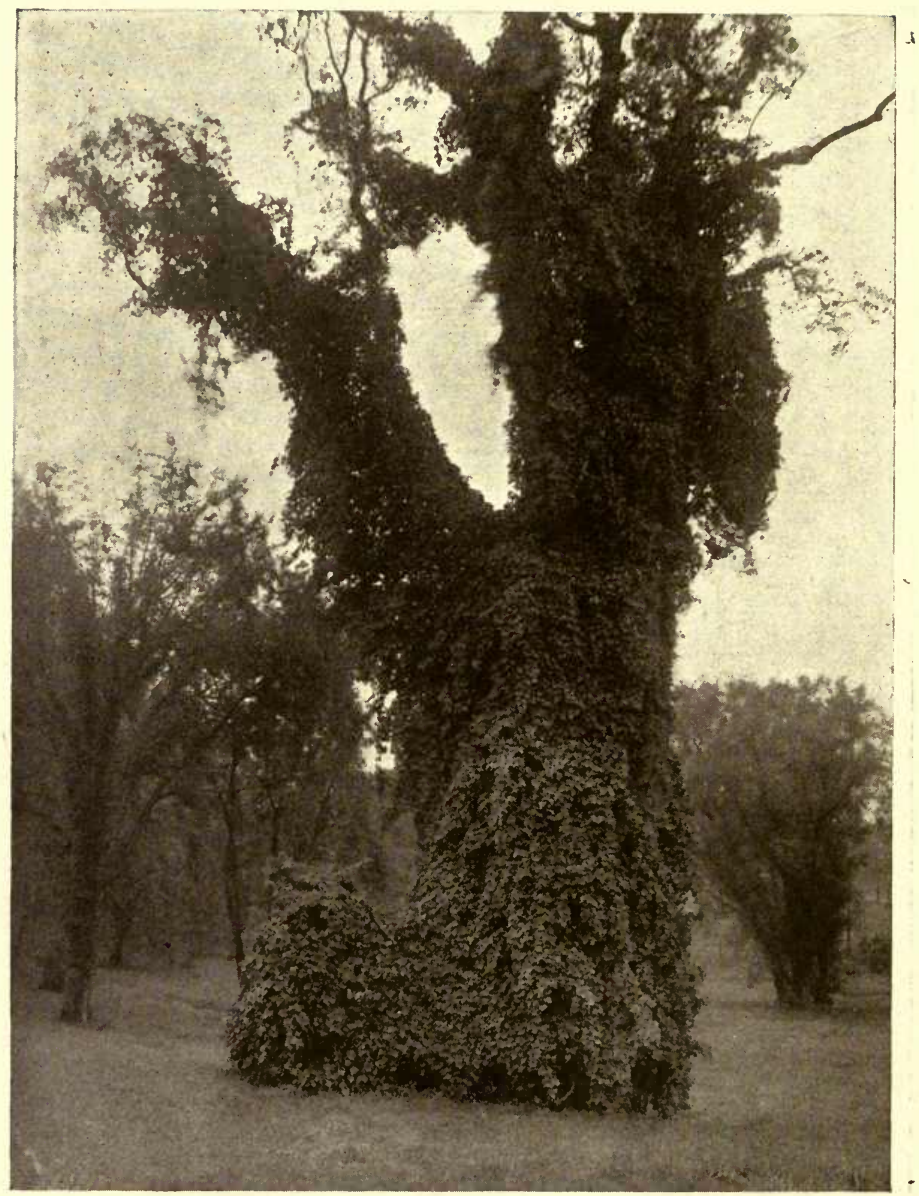

A DEAD TREE DRAPED WITH VINES 


\section{Ten] Annuals from Seed}

employed, while the brightness of the blossoms makes a very attractive whole.

The tall varieties make effective beds when pegged down, as the plants root wherever they touch the ground and send up flower shoots. Usually, however, they are grown on strings or trellises. The latter is a troublesome method, as they must be fastened to their support with strings. They are not climbers, but trailers, and have no tendrils or other means of attaching themselves to their support.

The finest bed of Nasturtiums I have seen is an elevated one built around a pipe which brings water from a distance. Some of the water-not muchreaches them, and they are given little, if any, attention, but in their elevated bed they grow luxuriantly, trailing over the sides of the ground and showing a brilliant mass of flowers until cut down by frost. Usually the Nasturtium receives too much water, and produces quantities of rank, lush foliage instead of flowers.

The new Nasturtium, Sunlight, is one of the finest varieties brought out in years-a pure, clear, golden yellow without any markings and of fine size. Its companion, Moonlight, is a pale cream, almost white, showing wine-coloured markings in the throat. For mixed varieties the hybrids of Madame Gunther are the most desirable, and the new Chameleon shows a variety of different coloured flowers on the same stem. 


\section{The Pansy Bed}

70 obtain the best results seed should be sown by 1 the middle of August, using fresh seed of the year if procurable. Rather than delay planting, however, it is better to risk the lessened vitality of last year's seed-sowing somewhat more generously as an offset. Sow as thinly as possible in the cold-frame or a spent hotbed, in drills two inches apart, drawing the earth from the sides of the drills and pressing it down with the board. The drills should run lengthwise of the bed from east to west, and each variety should be distinctly labelled with name and date of sowing. After sowing water well with the rubber sprinkler, cover with newspapers, and protect the bed with lath screens. Pansy seed germinates in from eight to ten days. When the plants have their second leaves thin out by setting some between the rows, and encourage growth by giving sunshine and water as needed and liquid manure once a month. The aim should be to get a sturdy rather than a quick growth to fit them for the winter. The soil in the frame should stand well above the soil outside, and a trench or hole, filled with stone or broken crockery, should be made in one corner, corresponding to the lowest level of the earth outside, to carry off any surplus moisture that may gather in the bed. When cold weather comes place the sash in position and, if it remains steadily cold-below 
freezing-leave the bed undisturbed until spring. The best results usually follow such a condition. If the winter is an open one, and the ground free from frost much of the time, the Pansies may be exposed to the sun and, on mild days, to the air. In this way considerable winter growth will be secured. Should the temperature fall sufficiently to freeze the ground inside the frame, the sash should remain closed and be protected with mattings, old carpet, or the like, and the plants allowed to thaw out in the dark. Never expose to the sun when frozen, but thaw out under cover.

As soon as the ground can be worked in the spring prepare a bed in an open, sunny situation by removing the soil to a depth of six or eight inches and spading in a generous amount of old, well-rotted cow manure - a wheelbarrow load to every fifteen square feet is not too much if it is old and thoroughly spaded into the soil. Replace the surface soil, or, better still, fill up the beds with leaf-mould or earth from the compost heap. Instead of the cow manure, old, wellrotted hen manure and chip dirt in equal quantities, with a liberal sprinkling of soot, may be substituted. Dig it well into the subsoil and cover with fine loam or leaf-mould, raking this fine and even and free from stones. Leave it to settle for a few days and then transplant the Pansies, setting them nine inches apart each way. Where several strains of Pansies are grown it is an advantage to plant each variety by 
itself, marking the line of separation by two or more rows of some distinct colour; such as pure white, clear yellow, or black. This enables one to compare the varieties at a glance and form a better estimate of their qualities than would be possible in a mixed bed.

During hot, dry weather the Pansy bed should be watered twice a day-at night and at noon. Watering the garden in the middle of the day may seem a reckless innovation to many, especially to the professional gardener, but years of experience have taught me the value of giving a plant water when it most needs it - and that is when it is parched with heat. Of course all plants will not stand water under a hot sun, but Pansies are not injured by it in any way. Pansies do not send their roots as deeply into the ground as most plants, but make many surface roots (hence we place the fertilisers well below the surface to induce a deeper growth), which even a temporary drying out of the top-soil will injure. A good soaking of the soil at night will last until ten or eleven o'clock the next day, according to exposure, and if another good wetting is then given with water fresh from the hydrant or well it will remain cool and moist throughout the twenty-four hours. The rapid evaporation caused by the hot sun will create a moist atmosphere around the plants, producing much finer flowers than would be possible in the dry air resulting from withholding water until night. Always plant Pansies in 
an open, airy situation, where the wind can have full sweep over them. There is no more mistaken idea than that Pansies should be grown in the shade. The aim should be to get stocky, upright plants with the flowers borne well above the foliage on stiff stems. This is impossible when plants are grown in the shade, where long, straggly branches will invariably be produced, with flowers at the extreme end. Then, too, plants grown by the side of the house, or in protected positions, where the wind cannot sweep over them, are much more liable to disease than plants grown in the open.

Fungoid disease and mildew often attack the Pansy in hot, muggy weather. The remedy for the former is to spray with the Bordeaux mixture, and for the latter to dust with sulphur. It will be better still-if the disease appear in August, as is usual-to remove all the old growth, cutting or breaking it off close to the crown, care being taken not to injure the tender new shoots, which will have started by this time. Burn the old tops. The new growth, being open to the air, will probably be free from disease, and will quickly fill the bed, giving an abundance of fine flowers throughout the cool days of fall. From a bed so treated I gathered five hundred blossoms the day before Thanksgiving with no apparent diminution of bloom. After removing the old growth the earth between the plants should be thoroughly cleaned and worked over with the trowel. 
From the blooming of the first Pansy until frost the bed must be gone over every day and all faded flowers removed. This is absolutely necessary to insure free blooming. The formation of a single pod of seed lessens the blooming capacity of the plant and reduces the size of succeeding flowers.

To maintain a high standard it is best to purchase fresh seed each year, buying the best to be obtained. Special mixtures sent out by the leading florists are made up of the best strains of the Pansy specialists in this country and Europe. One must not expect to purchase these collections for the price of ordinary seed, from twenty-five cents to fifty cents being the usual range of price. A packet of such fine strains as Giant Cassier and Giant Trimardeau should be included; and such special colours as may be wanted in larger quantities than the mixed packages furnish. Snow Queen is the best pure white, and the bed should contain a liberal number of these plants. Aurora is considerably larger than the Snow Queen, but shows purple markings in the centre, and is not'so fine in shape and texture. With the exception of size, Snow Queen is an ideal Pansy. If it is desired to carry the Pansy bed through the winter it may be done by using pieces of board, half a yard long, with notches cut in one end and the other end pointed. Put these through the centre of the bed a few feet apart, hammering the sharp end into the ground. Place long poles lengthwise of the bed, resting them on the 
notches. This forms a support on which the evergreen boughs, corn fodder, boards, bark, or anything that will shed water and protect from sun and wind. Leaves and litter are not suitable protection for Pansies, as they settle around the plants, freezing and causing them to decay.

When there is a large garden to be cared for it is not always expedient to carry the Pansy bed through the summer, as the daily labour of removing the withered flowers is very great. In that case it will be better to let the Pansies go when hot weather reduces the size and quantity of the flowers, replacing them with plants grown for the purpose, Petunias, bedding Begonias, Heliotropes, and the like.

Sow Poppy seed freely wherever there is a corner to spare, especially if it is a corner that would otherwise be neglected and grow up to weeds. It is surprising how many places may be found to sow them. A barren angle of a fence, a vacant strip behind or at the side of some outbuilding, an exposed spot among trees where nothing else will grow, a foot of ground here and there, in the perennial border and among late flowering plants, where the Poppies will have danced through their brief season of bloom and passed on before the former have discovered that they need the room. Use all these odds and ends of room, but, if possible, have a long, narrow bed of them-single and double, the deep blood red, the gorgeous scarlet, the wonderful Shirleys, whose delicate cups like 
crinkled silk seem to flush and pale with the tremulous colour of an opal as you look at them. Plant Eschscholtzias as a border, but sow Iceland and the Oriental Poppies, which are hardy perennials, by themselves; otherwise they are easily destroyed in the clearing-up time which comes after blossoming. There is a fine yellow Poppy, Hunnemannia fumariæfolia, which should not be overlooked. Poppy seed sown in August gives richer coloured flowers than spring-sown seed. Seeds of Eschscholtzia and Hunnemannia should always be sown in May. Sow broadcast as thinly as possible on soil that has been worked mellow and fine, pressing it into the ground with a board. As it is difficult to sow the seed thinly enough it is a good plan to mix it with fine sand-a teaspoonful or less of seed to a teacup of sand-and scatter that as thinly as possible. It will, even then, be found that the plants will come up too thickly and will need to be thinned to stand a foot apart each way. Poppies grown too closely will throw up one or two slender stems with only a few blossoms, while, given plenty of room, they will branch freely, producing dozens of flowers and remaining in bloom for weeks. Mark the finest blossoms on the plant from which you wish to save seed, removing all others as they fade, that they may not self-sow or check the bloom. If self-sown they are apt to come up so quickly as to be troublesome. Pull up the plants as soon as they have done blooming to add to the compost heap, and prepare 


\section{Ten] Annuals from Serd}

the ground, if not needed for other plants, for the fresh seed. When there is sufficient shade to grow them the blue of Myosotis and of Anchusa capensis is lovely among the Poppies.

\section{Phlox Drummondi}

TRY a border of the dwarf Phlox Drummondi, 1 sown to make a colour scheme. Set six to eight inches apart, in the form of scallops, the point coming between every other plant of the tall, perennial Phlox. Make the rows two or three plants wide at the centre, narrowing to a single plant at the point, using scarlet or pink, and filling in the space between the scallops and the straight edge of the bed with solid white. Or a double scallop, one beginning in the centre of the other, may be made of scarlet and buff, or pink and buff, filling in the large spaces between with white and the small spaces with Cope's Favourite Ageratum. The dwarf Ageratums grow very evenly and are admirably adapted for carpet bedding. Seed of the dwarf Phlox germinates very slowly. It should be sown where it will have bottom heat and be given plenty of time, frequently three weeks or more. The common Phlox Drummondi germinates more freely, and may be sown where it is to remain, thinning to six inches apart in the rows, or it may be sown and transplanted, which insures more even rows. 


\section{Salvias (Flowering Sage)}

T $T$ is surprising how seldom one sees the Salvia 1 grown to any considerable extent outside the public gardens and parks, though no other flower can compare with it in richness of colour and freedom of bloom, but there seems to be an impression that it must be purchased from a florist or grown from cuttings. Salvia is much more desirable for bedding than for any other purpose. In the house it is subject to attacks of red spider, which make it more trouble to care for than it is worth, while in the open ground it is remarkably healthy and free from insect pests.

Seed should be started carly in flats or hotbed, and plants set out where they are to remain, when all danger of frost is past, as they are very sensitive to cold. Muck or marsh earth seems the most congenial soil in which to grow the Salvias, and if this is supplied they will need little care beyond watering during the summer.

I have grown the Salvia splendens-the usual height of which is about two and a half feet-to a uniform height of five feet in a bed of marsh earth, with a supply of water from a pipe, keeping it constantly moist. They will do well in the hottest situation if well supplied with water, and even better in partial shade-the foliage being a deeper green and the colour of the blossoms richer and more velvety than when exposed to full sunlight. For years I have 
grown them around a twelve-foot bed of Ricinus and Cannas, and notice that the plants are always much finer on the north side.

Try them as a border to a bed of Cannas or Ricinus, edging them with white Sweet Alyssum or dwarf Ageratum. They root readily in wet sand in a warm situation, and if a house-plant is available it may be used for cuttings instead of sowing seed.

Seed may be saved without injury to the plants as it ripens, and must be gathered before the flowers entirely fade. The corolla or lip of the flower falls out, leaving four white seeds an eighth of an inch long at the base of the calyx, which remains fresh until the seeds have ripened, when they may be shaken out. By going over the plants daily one soon saves a fine lot of seed, which may be depended upon to germinate. The Salvia seed germinates in about five days. But less vigorous seed will continue to appear for two or three weeks after sowing, and the soil should not be disturbed until all have had time to appear. They require considerable heat to germinate freely, and when this is supplied will give very satisfactory returns. Bonfire, Clara Bedman, and S. splendens are the best of the scarlet-flowered variety. The white-flowered Salvias would be desirable if the blossoms were more closely massed on the spray; as it is they are too scattered to have any value. S. patens, however, when brought to perfection is magnificent, the individual flowers being double the size of the 
scarlet and of the most wonderful shade of blue. It is seldom seen, but should have a place in every garden, as it is a colour rare among flowers, the nearest approach to it being the Monkshood. It is a tender perennial, but may be wintered in a warm, dry cellar, dying down to the ground usually, but starting up from the root in the spring.

Sweet Alyssum and Golden Saxatile are both desirable for edging or for rockwork, and may either be sown in the open ground where they are to remain, or in a seed-bed and transplanted.

\section{Sweet-peas}

SO much has been written on this subject that the $S$ culture of Sweet-peas might, without much exaggeration, be called a cult. Though blooming with its head in the sun, the Sweet-pea loves to plunge its roots deep in the cool, moist earth, and the seed should be planted as early in the spring as the ground can be worked, or, better yet, in the fall. This late fall planting has much to recommend it, as there is more leisure and the work is apt to be better done than in the hurried days of spring when everything seems to call for immediate attention.

The seed should be planted deep in two rows a foot apart, running, if possible, north and south, that the plants may receive the maximum amount of sunshine. Placed in this way, they receive both morning and 
afternoon sun. A strip of wire netting five feet high should be stretched between the rows and securely fastened to stout posts driven into the ground. Sixfoot netting is even better than five, as the Sweet-pea loves to climb, and blooms better if not thwarted. Dig on each side of the netting, as close as may be without breaking the space between, a trench a foot or eighteen inches deep and as wide as is necessary to work conveniently. Place in the bottom about six inches, when trodden down, of old, well-rotted cow manure, fill in about six inches of the removed soil, making it fine and mellow; sow the seed and cover with two or three inches of soil and press firmly down. If planted in the fall protect with several inches of rough manure, removing it in the spring that the soil may get the benefit of the sun's warmth. When the plants are two or three inches high thin to six inches apart in the rows, and draw up part of the soil removed from the trench. Add more as the plants grow until it is all banked up against them, leaving a slight trench between the ridges and the surface of the ground.

The wire should come close to the ground that the plants may have support from the start. Do not water until necessary, then sufficient water should be poured into the trench to thoroughly soak the ground at the bottom of the roots, but do not turn it on the foliage or stems. Thorough and frequent cultivation should be given during the blooming season. 
Should it become necessary to shower the foliage during dusty weather it would better be done early in the morning or sufficiently early in the evening to allow the foliage to dry before the chill of night. This guards against the blight and mildew, so prevalent in Sweet-pea culture.

When for any reason it is not convenient to cultivate frequently, a mulch of lawn clippings will keep the ground about the vines cool and moist. To insure freedom of bloom all faded flowers should be removed each day. If the flowers are cut as fast as they open the quality will be improved. Under no circumstances should seed be allowed to form, as the ripening of the seed is fatal to the flowers.

There is such a bewildering variety of Sweet-peas that any suggestion of choice is impossible, but usually the special collections put up by seedsmen will prove more satisfactory than those of one's own choosing, if one is unfamiliar with the names of the varieties.

\section{Verbenas}

T $\mathrm{N}$ sowing the seed of Verbenas it is best to keep colours separate, as white, pink, scarlet, scarlet with white eye, and the new Mayflower Verbenaone of the finest novelties brought out in recent years.

They should be started early in flats or hotbed, soaking the seed in hot water for three or four hours before planting. It germinates very irregularly, often 
coming up after one has ceased to expect it. The soil should be kept moist so long as there is any chance of more plants appearing. Verbenas will thrive in any good soil, striking root wherever a point touches the ground. Cultivate, if in loam or stiff soil, as long as there is room to work between the plants, which should be set at least a foot apart. Verbenas do finely on the rockwork, seeming to enjoy the cool corners they find under the stones, and the finest $I$ have ever grown have been in such a situation.

Vincas (Periwinkles) are an exceedingly beautiful and little known tender perennial worthy of extensive cultivation, as easily grown as an Aster or Verbena, and very effective in large beds. For the price of one greenhouse plant a dozen plants may be raised from seed. The foliage is deep green and glossy, and large single flowers of exquisite colour and texture-pure ivory white, white with a crimson eye, and rosy crimson-are borne at the end of every branch covering the plants, which grow from fifteen to eighteen inches high and nearly as broad. As a border for a Canna bed nothing could be better, and they make fine symmetrical winter bloomers. No finer plants for house decoration could be desired.

The seeds, which should be started early in hotbeds or flats, germinate in from ten to fifteen days, sometimes earlier. Set out plants, when all danger of frost is past, in muck, if possible, or in well-enriched loam, setting a foot or fifteen inches apart each way, cultivat- 
ing once a week, if in loam or stiff soil, but if in muck it will only be necessary to mulch. Water every day during the hot weather, and if kept from seeding they will bloom from June until cut down by frost. They do well in full sunshine or in shade, but must have a fair amount of moisture. If no seeds form plants may be lifted in the fall and potted in large pots for winter blooming.

Small plants of the Chrysanthemum obtained from the florist in the spring will, with proper care, make fine blooming plants by fall. Plant out, when all danger of frost is past, in a sunny bed composed of rather sandy loam and muck well manured and made deep and mellow. Set the plants from a foot to eighteen inches apart each way and cultivate at least once a week during the summer. They should never suffer for water, as if once allowed to dry out they never fully recover.

When the plants are six or eight inches high pinch back to four inches. Allow four branches to spring from this main stalk, removing all others. When these are four inches long pinch back again, allowing each of the four shoots to form three or four branches and nipping out all others as they appear. If a few very large flowers are desired, allow only the four branches to grow from the main stem, removing all other shoots. When the branches are six inches in length pinch back for the last time not later than August Ist, after which they should be allowed to 
grow on undisturbed, removing all but the terminal buds if fine flowers are desired.

Lift by September Ist, transfer to large pots or boxes, according to the size of the plants. The soil should be given a good watering the day before lifting, that the earth may cling to the roots and that the plant may be in the best condition for moving. Cut around the plant with the trowel, leaving a ball of earth as near as possible the size and shape of the pot it is to fill. Avoid disturbing the roots.

Set in a cool, shady place for a few days and keep in a rather cool, dry atmosphere after removing to the house. Water freely and give liquid manure once a week. Do not shower the tops after buds appear, or keep where bulbs are growing in water, as moisture at this stage is apt to cause the buds to blast. Chrysanthemums are quite certain to be attacked at some stage of their growth with black aphis, or lice, which are very troublesome to get rid of once they have gained a foothold. It will be wise, therefore, to keep the foliage constantly dusted with tobacco at all seasons of their growth, as in this form tobacco is most effective. Once the pest has gotten a start fumigating with tobacco smoke will be necessary. Shut the plants in a close room or box and smoke thoroughly. 


\section{Chapter ELEVEN}

\section{Vo'tnes}

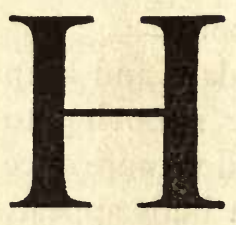

ARSH outlines of buildings, a dead tree, a dilapidated fence, a sunny window, an obtrusive outbuilding, may be transformed by the use of Nature's drapery. There exists in the minds of many, unfortunately, a prejudice against vines on the house as injurious to walls. This is entirely unfounded, the contrary, so far as I am able to judge, being the case, especially on the south and west sides of frame houses, where the paint and consequently the woodwork, will be found in a much better state of preservation when protected by such vines as Ampelopsis Veitchi, Virginia Creeper, Woodbine, and the like, than when exposed to the burning, blistering rays of the sun. Vines make a thick growth of overlapping leaves which shed rain and prevent its penetrating to the walls. In England, where it is much used, it is said that walls covered with Ivy are almost indestructible, so hard and dry has the cement remained under its protecting care. 


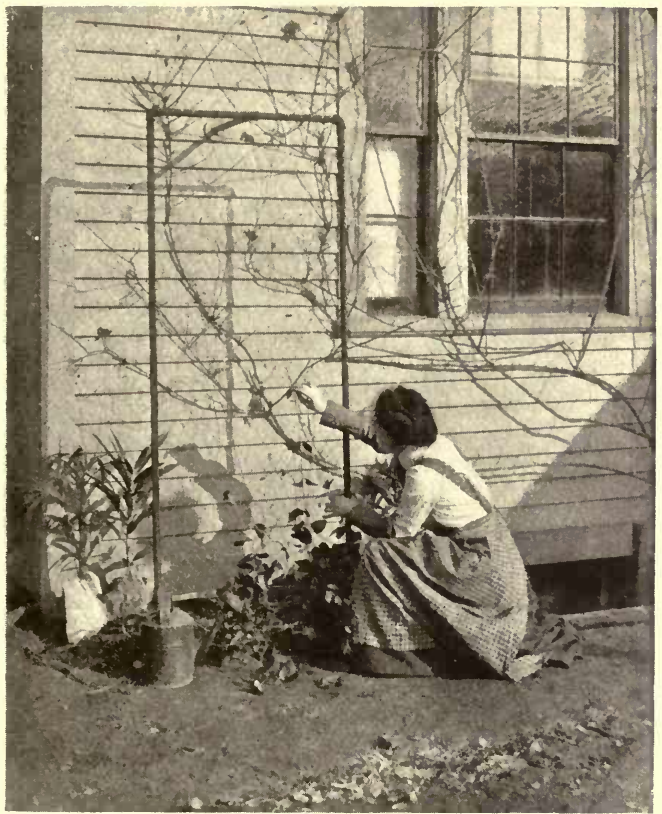

FURNISH SUPPORT FOR VINES TO RUN ON

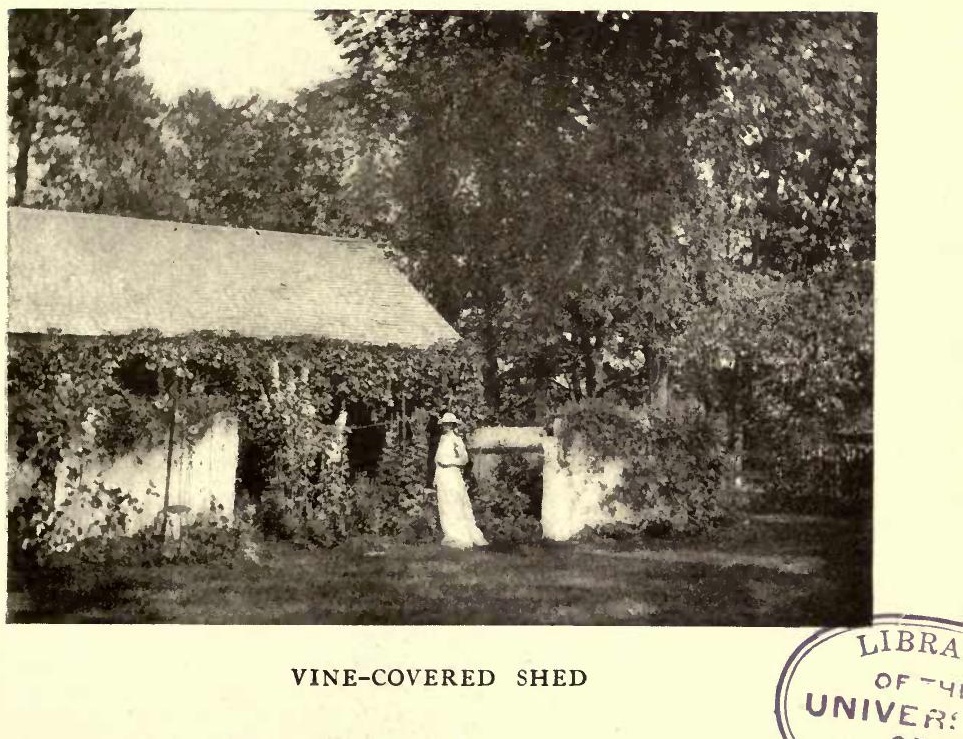




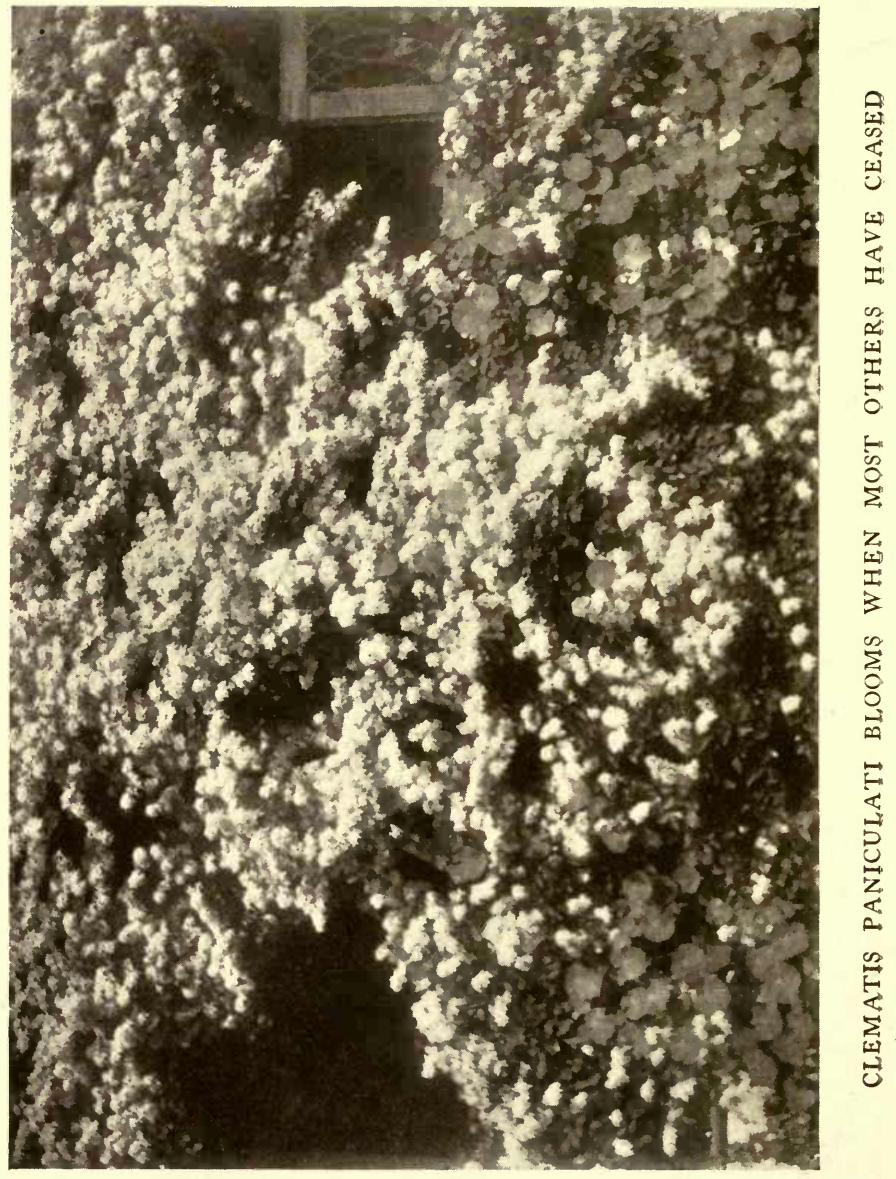




\section{Adlumia}

(Mountain Fringe, Climbing Fumitory, Alleghany Vine)

NE of the prettiest of summer vines is the Adlumia, though it lasts but one short summer. It is a biennial, stooling the first summer and the second summer bursting into a wealth of tender green foliage, as finely cut as a fern, with hundreds of sprays of delicate flowers-a delightful vine when grown on the north side of the house, where it retains its fine green throughout the season, though in the hot sun it is inclined to burn. It is especially appropriate for funerals. It self-sows, and once established there is sure to be an abundance of it from year to year. In the fall seeds may be scattered where the plants are to remain, or the seed may be germinated in another spot and the seedlings transplanted later. As the plants always receive a check when moved, it is better to do so as early as possible in the fall, that they may become established before cold weather. Plants should be set two feet apart.

Cobæa scandens (Cup-and-Saucer Vine) is a most desirable summer vine. It grows to a great height and blooms freely, throwing great, bell-shaped flowers-pure white, greenish white, lavender, mauve, and purple-from the axil of nearly every leaf. The flowers of the purple variety are pale green at first, changing through all the shades of lavender and purple to plum. 
There is another variety-the San Salvador Cobæa -that is even more desirable than the C. scandens. The flowers are much smaller, but have greatly exaggerated stamens that give them distinction. Its chief beauty, however, is the foliage of light, translucent green, to which the sun, shining through it, gives a luminous quality rare in vines. In manner of growth, too, it is superior, its many-lobed leaves lying parallel to, or flat on the netting, instead of at right angles, as is the case with $\mathrm{C}$. scandens. Both these vines do well in a north or east exposure and require less water than most vines. They are admirable for covering an old tree or any partly dead wood.

Seed should be started in the hotbed early in spring, setting them on edge and covering a quarter of an inch deep. Unless the soil appears dry they should not be watered until the plants are up and have their first true leaves. Set out when danger of frost is past in mellow soil, watering as needed, and giving support for the vines to cling to. To stone and brick, or the bark of a tree, they will cling of themselves, each leafspray ending in a tendril that attaches itself to any rough surface. I have never been able to ascertain what height they will attain if given support, but the top of a reasonably tall tree falls short of their ambition.

The Centrosema (Butterfly Pea) is rather a hard vine to propagate from seed. Seeds germinate freely, but the young plants seem strangely lacking in vigour, 
so that frequently, after making a few inches of growth, they refuse to go further, and gradually dwindle away. It is therefore better to make several sowings, soaking the seed in hot water for an hour before using, and planting in hotbed or cold-frame. If it is dropped an inch or two apart in the rows there will be no occasion for disturbing until it is time to transplant into the open ground-which would better be deferred until the plants are six or eight inches high. They should be moved with as little disturbance as possible, pressing the trowel down its full length and lifting and transferring to their permanent position on the east side of the house in one operation. Water and press the earth around the roots and furnish immediate support. Thus treated they will usually thrive and bloom in a few weeks, continuing until frost unless seeds form, which should not be allowed on young plants.

Were they much more difficult to raise, it would still be worth many trials and failures to secure one thrifty plant, so lovely it is when in bloom. I do not remember another plant whose blossoms give one such an idea of perfection-of exquisite and minute finish, as this lovely Centrosema with its beautiful colour, delicate markings, and symmetry of form. Before it bloomed I had begun to wonder whether it was worth all the trouble, but when I saw the first perfect blossom all doubts vanished and I would go to much greater trouble to possess it. 
The Centrosema is of slender growth, and seldom exceeds eight or ten feet. Plants should be set a foot apart in front of a wire trellis or other support. They are hardy, but should be given protection in winter.

Gourds are a very useful family. They are an ornamental feature of the summer garden, and afford an economic and unique addition to the winter's supply of plant receptacles, hanging-baskets, low bowls for Tulips, Crocus, and other bulbs. Many of them are highly ornamental and graceful climbers-as the Wild Cucumber, Bryonopsis, Coccinea Indica, and Abobra, which have delicate foliage and showy fruit, and may be grown where any quick-growing vine is wanted. They are especially good for covering rear fences or unsightly outbuildings.

Some of the varieties have large white flowers which are finer than a Clematis, and of the fruit of large-flowered ones the prettiest hanging-baskets are made. Saw them in two when thoroughly ripe and dry, remove the pulp, scrape the shell clean and thin and give a coat of green or brown shellac inside and out, and hang with brass chains. They are more satisfactory if the gourds are a year old and perfectly dry. A hole must be made for drainage, and in case of bowls, tiny supports fastened to the bottom with glue to raise them from the table, as without the free circulation of air they are liable to mould.

Seed must be sown as early as possible that the fruit may have time to ripen before frost. Set out 
when all danger of frost is past in any garden soil in a sunny position where they will have good support, as they are vigorous and rapid climbers and will quickly go to the top of a tall tree. They are liable when first set out to be eaten off by cutworms, and they should be protected by a bottomless tin can sunk into the ground two or three inches, care being taken that there are no worms inside the can. The gourds do not grow for some little time after setting out, as they are making roots; but once they begin the development is rapid.

The variegated Japanese Hop is another summer vine that should be extensively grown. Its large, handsome foliage, freely splashed with white, is very showy and effective, and it thrives in almost any situation and soil, though paying well for extra care or attention in the way of cultivation, watering, and food. The vines are not hardy, but, as they self-sow, once established they are practically permanent. Several plants should be set near each other, as only the female plant bears seed. The leaves of this are smaller and the vine more slender. The great-leaved, robust vine bears no seed.

It is better to plant the seed in the fall, as when planted in the spring it may not come up until the following year. If this is the case the ground where it is sown should be left undisturbed until the following spring, when it will make an early appearance. When it does sprout the same season, the seed ger- 
minates in from eight to ten days. The plants do equally well on north, south, east or west walls, but should be kept sufficiently watered on the south or west.

There is but one precaution I have found necessary in growing the Japanese Hop: namely, to give it a rather elastic support, a twine trellis being better than a rigid wire one. The finest Japanese Hop I ever saw grew over a south window on a trellis of chicken netting; the growth was wonderful, and the great leaves were beautifully splashed with white. I was exceedingly proud of the vine, but one day I saw it hanging limp and withered from its trellis, and an investigation revealed the astonishing fact that it had grown so rapidly and attached itself so firmly to the unyielding wire that it had pulled its roots entirely out of the ground, literally committing suicide. Since then I have used a more yielding support.

The Japanese Morning-glory should be started in the house or hotbed and not transplanted into the open ground until the nights and ground are warm.

Many of the varieties received direct from Japan are only adapted for growing in pots; that is how the Japanese grow them, and we can hardly expect to improve on their methods. Pot off all plants showing unusual markings, or oddly shaped leaves, and plunge in the sand-box, giving sunshine and abundance of water and using large pots, or shifting frequently as needed. Give liquid manure once or twice a week. 
Furnish support for the vines to run on, either a trellis or sticks in the sides of the pot and strings run back and forth through and around them, or they may be trained against the wall back of the sand-boy: Most of the seeds purchased here, however, are grown in this country, and the plants are as rugged as the old-fashioned Morning-glory. It will be noticed that those with oddly shaped leaves and broad, hairy stems rarely bloom here, the buds appearing too late to develop before frost. Grown in pots these might give some interesting specimens. If only a few of the buds are allowed to develop the size will be greatly increased.

The Maurandya Vine is one of the most satisfactory for low trellises, window-boxes, vases, rockwork, and the like, in summer, and for hanging-baskets in winter. In the open air it attains a height of five or six feet, giving an abundance of pink, white, and lavender-coloured, foxglove-shaped flowers, an inch and a half in length. The smooth, shining leaves are ivy-shaped and cling to supports by a twist of the stem. It grows readily from seed, and germinates in from twelve to fifteen days. For trellis and outdoor work start early in flats or hotbed, setting out when danger of frost is past, but for winter use June is early enough to sow seed. It requires no special treatment, doing well in any situation with good soil and sufficient moisture. This is one of the most graceful and useful vines for either summer or winter. 
Thunbergias (Black-eyed Susans) like a warm, sunny situation, and in good soil will grow six or eight feet tall and be covered, until cut down by frost, with a wreath of tube-shaped, flat-faced blossoms two inches in diameter-pure white, white with black eye, yellow with white eye, and yellow with black eye. They are very valuable for covering low trellises, the foundations of porches, window-boxes, urns, or rockwork where a small vine is needed. They are admirable as basket or bracket plants in winter. They grow freely from seed, germinating in about twelve days, and should be started early in flats in the house or the hotbed. Much finer plants are grown in this way than can be purchased from the florist. Their only enemy is the red spider, and they should be showered frequently to prevent an attack.

The Manettia Vine is one of the most satisfactory vines for winter blooming, requiring only a small pot and a place in a sunny window, and blooming better when pot-bound. A daily watering, and occasional doses of weak liquid manure when the other plants are getting it is all the care it needs. It does not require a warm atmosphere, blooming freely in a temperature of about $50^{\circ}$, and giving an unfailing succession of its bright little flowers every day during the winter. It is that rare thing - a plant which the florists have not overpraised. It is every bit as good as it is claimed to be. Though equally at home in a hangingbasket or on a trellis, I have found it most attractive 
when grown on strings across the window in company with Solanum jasminoides, whose sprays of airy white flowers contrast with the orange and scarlet of the Manettia. A small plant obtained from the florist in spring and potted in a four-inch pot, with good compost, will be ready to bloom by November, and will remain in bloom from that time until spring, when it should be repotted in a six-inch pot and plunged in the sand-box to grow for winter blooming. The only precaution necessary is to keep it in a small pot, as it blooms more freely when pot-bound. Cut back if not branching freely, as the bloom comes at the ends of the new growth.

\section{Clematis (Virgin's Bower)}

$7 \mathrm{HE}$ large-flowered Clematis are the most expen1 sive vines we have. So slowly do they propagate from cuttings that the price remains high from. year to year. The cheapest way to obtain them is to raise them from seed and, though this is a more or less uncertain method, the expense is so slight compared to the purchase of plants that where many are required it is worth repeated efforts. Plant the seeds in flats in the house either in fall or spring. Cover an eighth of an inch and press the soil down firmly, keeping moist and warm. They germinate in from six weeks to a year; for this reason fall planting is desirable, as the soil may more easily be kept in the 
right condition. When the plants are large enough to handle, pot off into small pots and plunge in the sand-box, if the weather is warm enough, or in a sunny window if cold. Winter in a frost-proof cellar the first winter, putting them in the open ground where they are to remain till the following spring. The plants will give a few blossoms the second season, enough to show the variety, and the next year may be expected to bloom freely. Plants raised from seed are more likely to bloom and do well than those from cuttings.

Clematis paniculata comes more freely from seed than the Jackmanni strains, and should be largely grown, as it is one of our loveliest vines and blooms when most others have ceased. Clematis flammula self-sows and established little plants are continually coming up in unexpected places, which may be removed to any desired position, as this variety does not in the least mind being disturbed. All Clematis are benefited by winter protection, and such varieties as Ramona and other spring bloomers should have the tops protected with sacking or old carpet. Mrs. Edward Andre dies to the ground in the winter, but should be well protected around the roots. Many growers cut back Clematis to within a few feet of the ground each fall, but where large spaces are to be covered one loses much time, as the frost usually does all the trimming necessary. The early spring bloomers from last season's wood and cutting back in the fall 
simply lessen the blossom points. If it is necessary to trim for symmetry or lack of room it should be done immediately after the plants are through blooming, that they may have abundant time for new growth.

\section{Bignonia Radicans}

\section{(Trumpet Vine)}

T $T$ is to be regretted that this fine vine is so com1 mon and old-fashioned that no one seems to appreciate it sufficiently to bring it up to its really magnificent possibilities. When grown as a shrub no finer plant for a hedge could possibly be desired. For this purpose the plants should be set about three feet apart, or even closer, if it is desired that the hedge should be useful as well as ornamental. Set in an even row where the hedge is desired, tie each plant to a stout stake, and allow only one branch to grow, cutting this back when three feet high to form the head, which should be made to branch freely. By the time the stake has rotted away the plant will have made a trunk as large as one's wrist and perfectly selfsupporting. All dead and weak branches should be trimmed out each year and the hedge kept pruned back to symmetrical growth. If the seed-pods are not allowed to form the plant will be in bloom nearly all summer. Such a hedge will be a thing to bequeath to posterity along with old oaks and fine elms. 
The Trumpet Vine is equally desirable as a climber, and on some surfaces is self-supporting, but on others, as the side of a building or a board fence, it often fails to attach itself, and in that case must be artificially supported. This should be very securely done, as a hard storm may tear a heavy-topped specimen entirely away from its support and do much damage. The best support is afforded by stretching a galvanised wire across a branch, just under a joint, and fastening each end by a staple driven firmly into the building.

Grown as a shrub on the lawn the Trumpet Vine is very fine and should be trained to a stake and grown the same as a Kilmarnock Willow. Every year, as my Bignonias bloom, I grow more and more enthusiastic over their possibilities, and wish more people would grow them with some definite aim in view. 


\section{Chapter TWELVE}

\section{Ornamental Joliage 羽lants from Ged}

\section{Canna (Indian Shot)}

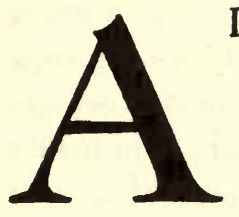

LL Cannas-the gorgeous orchid-flowered, as well as the old-fashioned sorts - can be easily and cheaply grown from seed and will give blossoming plants almost as soon as those started from bulbs. When one must buy plants and the fine new varieties are desired, the starting of an eight- or ten-foot bed is a matter for economical consideration. Five or six dollars is as little as one can expect to pay for such a bed if plants are purchased, but by starting the seed the cost is reduced to a mere bagatelle. It is better to buy seed by the ounce, as not all will come up, and one should make sure of a sufficient quantity. The seed must be filed on the end opposite the germ, so that the white shows through plainly, and the best way to do it is to tack a piece of medium sand-paper to a piece of wood and rub the seed on that. It is better to do this before they are wanted, as it is a 
tedious process when one is in a hurry. Soak the seeds in hot water for an hour or two before planting and sow in hotbed or flat, keeping moist and warm. When large enough to handle, prick out in thumbpots and place in a warm, sunny window. It would be even better to start them in tiny pots, plunged in a box of sand or in the hotbed, to avoid danger in removing, as they sometimes suffer in the process. Though one of the toughest plants when of some size, the little seedlings are exceedingly tender. Shift as needed until time to place in the open ground when all danger of frost is past. Plant, if possible, in muck well manured, as Cannas do exceptionally well in that soil and can scarcely have too much food and water. Unless one has city water or other supply it is better to make the Canna bed somewhat lower than the lawn, that all the water may be retained and not run off, as it will if the beds are raised. If tall-growing varieties are grown in the centre the effect will be as good as though the bed were raised and less water will be needed. A good mulch of lawn clippings will help to keep the soil moist, mellow, and free from weeds and will greatly lessen the care of it. Seed sown in February or March will give blooming plants in June, and by fall there will be a fine lot of roots to store away for another year.

Coleus, which are practically indispensable in all ornamental bedding, are easily raised from seed and will make fine plants by June. Start seed in rather 
deep flats in the house in February or March, covering lightly and giving a warm place (see directions for growing house-plants from seed). They germinate in from five to seven days. As soon as the plants have their first true leaves place in a warm, sunny window and encourage them to grow as rapidly as possible. When they have two or three leaves the colours will be sufficiently developed to admit of making selections, and if the box is at all crowded they can be potted off and grown on until time to plant out. Coleus are very sensitive to cold and should not be planted out in the open ground until the nights are warm. Never allow the Coleus to flower, as this injures the foliage greatly. Pinch out the flower heads as they appear. Water liberally and pinch back occasionally to symmetrical form. Any soil that suits the Canna, or other ornamental foliage plant, will do for the Coleus-a light, sandy loam enriched with manure is as good as anything, and leaf-mould answers admirably.

Where a quantity of Cineraria, or Dusty Miller, is needed for borders, it is much more economical to grow from seed, starting them in hotbeds and planting out when all danger of frost is past, setting six inches apart. 


\section{Ricinus, or Castor-oil Bean}

DROBABLY the most effective and tropical-looking plant in cultivation to-day is the Ricinus, and fortunately it is within the reach of everyone. It is usually seen as a solitary specimen on the lawn, or as the centre of a bed of other plants, or probably in a long row; it is more effective, however, in a group, and thus grown makes a good background for low plants. Seed should be started early in house or hotbeds. It germinates in twelve to fifteen days. The best results will be obtained when started in the house by planting in three- or four-inch pots. Put two or three seeds in a pot and remove all but one if more come up. Before filling the pots with earth mixed with good compost, a piece of shard, or flat stone, should be placed over the drainage hole to confine the roots, as they make a very rapid growth. Shift into larger pots as required, and plant out when all danger of frost is past in a deep, rich soil. Marsh earth is best, but where this is not available any good garden soil will answer if heavily manured and well watered. The young plants are somewhat backward after transplanting and frequently refuse to grow at all, so that it is well to have a few plants in reserve against a possible emergency. After the plants are a foot high, little if any trouble will be experienced. The newer Zanzibar varieties are the most desirable, being very fine both in colour and development, growing 

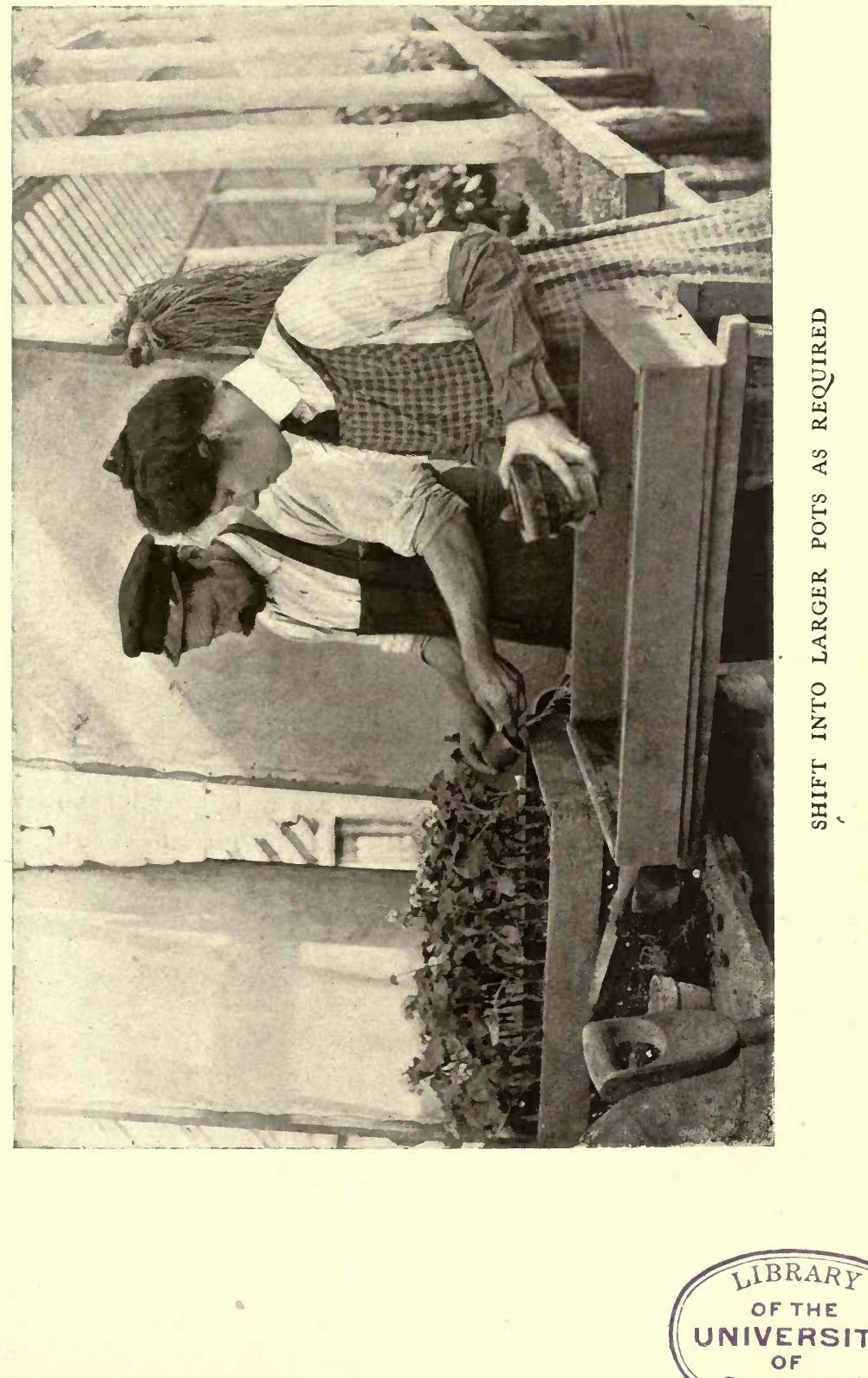


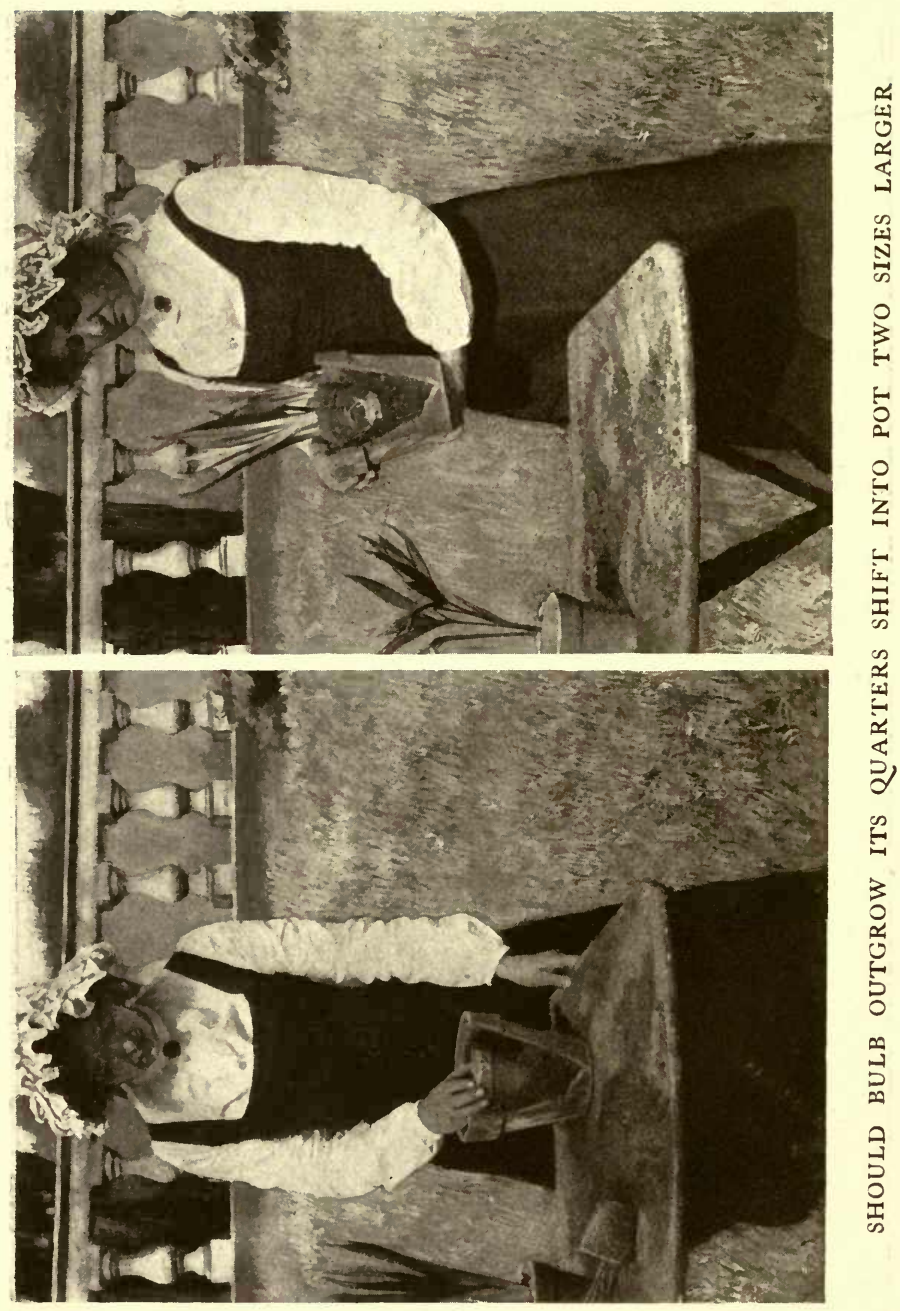


under favourable conditions from eight to ten feet tall with leaves three feet in diameter.

Banana plants are very showy and attractive and in the North are more or less of a novelty. They may be planted out in the open ground or in tubs when all danger of frost is over. Though less sensitive to root disturbance than the Ricinus, they are very impatient of the immediate presence of other plants, and young plants should be grown by themselves. Robust twoyear-old plants, however, may be used as centres for beds of Cannas or similar plants with fine effect. When obtainable they should be given a compost of muck and old manure and supplied with a very liberal amount of water; the water from the laundry and kitchen should be saved for them, as one can scarcely overfeed them. Give a warm, sunny situation, protected from rough winds, which whip and tear the broad leaves, rendering them most unsightly. A southeast angle of building or shrubbery furnishes an ideal location. In the fall the plants may be removed to the cellar in the tubs in which they have been grown, or they may be lifted, if grown in the open ground, and planted in suitable tubs for the adornment of the conservatory or living-room. Grown indoors they are very ornamental, the foliage being perfect, which is rarely the case out of doors. It is also much easier to carry the plants through the winter in this way; as they are very sensitive to cold and damp when dormant and cannot be carried suc- 
cessfully in a cellar where these conditions exist, even though it be free from frost. In the South-and the same method may be employed in the North, provided the cellar conditions are right - the plants are dug up, the soil removed, and the roots wrapped in gunnysacks and laid on a shelf in the cellar, all the leaves being removed except the central one, which must be carefully protected from all injury. 


\section{Chapter THIRTEEN}

\section{Bulbous and Tuberous=ronted 羽lants}

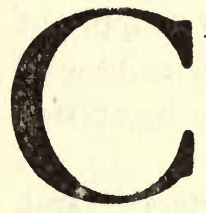

ANNAS may be started any time in April or May. The old-fashioned tall-growing varieties may be put in the open ground early in May. Cover with three or four inches of soil and protect the bed with a little rough manure if the nights are cold, the finest of the manure being left to enrich the soil when the plants are up.

The large-flowering French and Orchid-flowered Cannas are delicate and very sensitive to cold and damp and should be started in the house with heat. Divide the roots into points and pot separately in leaf-mould, or they may be placed in baskets of sand set in a warm, sunny place and kept constantly moist; this is the simplest and best way of handling them. Cannas are less likely to mould or decay in sand than in soil, and it is easier to keep a uniform degree of moisture in the baskets than in the small pots. The baskets should be partly filled with fine white sand and the roots laid in place, points up, as closely as 
convenient, and sufficient sand added to cover them. They must not be planted out until all danger of frost is past and the nights are warm, and they should then be handled very carefully to avoid injuring the tender roots. Give them a soil of muck or heavily manured loam and abundance of water. The most convenient place for starting bulbs of all kinds is a warm upstairs room, over a kitchen or elsewhere, with a south or west light. A wide shelf may be arranged under the windows and one's entire supply of bulbs started there in pots and baskets out of the way. Seeds of flowers and vegetables may also be started there to advantage.

Dahlias are best started in the baskets of sand, putting the bunches in whole, with the crown just below the surface of the sand. When they have sprouted and the weather is warm they should be removed from the sand and carefully divided. A number of tubers will have failed to start, while others will have thrown several shoots. If the number of plants is not sufficient more may be secured by grafting part of the green shoots into the dormant toes. Remove a shoot, cut the end to a wedge shape, remove a corresponding wedge from the crown of a toe and insert the shoot; it should rest in the toe an inch or more and be placed in the ground at once -drawing the earth around it snugly that the scion may be in no danger of separating from the toe before it has formed a union. Only one shoot should 
be left on a tuber, and the removal of the extra ones for grafting is a distinct gain. Whenever it is necessary to divide the roots a portion of the stem with a well-defined eye must be given to each division, otherwise there will be no top growth; the toes will root, but they will not grow. For further directions see chapter on growing Dahlias from seed.

Caladium esculentum, or Elephant's Ears, is a native of the Sandwich Islands, where it furnishes a staple article of food called Poa. The root when cooked is like a potato. It is better to start separately in pots an inch larger than the bulbs, setting the top of the bulb just above the surface of the soil. Pot with muck or good compost and keep moist and warm. They respond to heat and moisture the most readily of all dormant bulbs, beginning to grow at once and making steady progress, the root growth keeping step with the top much more uniformly than is usual with bulbs that are wintered dry. It is an ideal plant for the amateur, as easily grown as a hill of corn. If fine plants are desired only those bulbs showing a live centre-shoot should be used. If the winter conditions have been favourable the bulbs will show a strong centre-shoot or rolled-up leaf; where this has decayed or dried off there will frequently be side-shoots which are worth saving when the supply of bulbs is small, and which will produce fair results, but for really good plants the centre-shoot is necessary. 
Plant out when all danger of frost is past, in muck if possible, or in heavily manured loam; the more freely they are watered the finer will be the growth. Old bulbs should give leaves three feet or more in length and correspondingly wide.

Single specimens are fine in pots, vases, or tiles, but they are really seen at their best in large clumps on the lawn, or edging beds of Cannas or other subtropical plants.

They are easily wintered and multiply very rapidly; and, as much better effects can be obtained by planting largely of one variety, an effort should be made to have a generous supply. Aim for a tropical luxuriance of effect-whether the plants used are Cannas, Caladiums, Ricinus, or all three.

Tuberous Begonias should be started at the same time as the Caladiums, Cannas, and other tuberous plants. Pot singly in small pots of leaf-mould, setting the tuber level with the surface of the earth, but shaping the soil away from it toward the edge of the pot that water may not settle around it. The side showing a slight depression is the top. Often it is difficult to determine this, in which case the bulb may be laid on the surface until growth begins and the fact can be determined, when it may be potted. Do not keep too warm, as that induces a leggy growth; a temperature of about $60^{\circ}$ is right.

Bed out, when all danger of frost is past, in partial shade. In England it is claimed that they will stand 
the hottest sun, but the atmosphere of England is very different from our dry air, and the tuberous Begonia does better with us if shaded. Where there is no natural shade an awning of cotton cloth during the hottest part of the day answers every purpose. Gloxinias are started the same as tuberous Begonias and require practically the same treatment, but more heat. Fuller cultural directions are given in the chapter on growing from seed.

Fancy-leaved Caladiums, though belonging to the same family as C. esculentum, bear little resemblance to that sturdier branch, being small in growth, gorgeous in colouring, and exceedingly delicate. Unlike the Crotons and Coleus, which revel in full sunshine, they develop their beautiful colours best in partial or complete shade. They do, however, love a warm atmosphere and must be guarded against sudden chills and draughts. They are very desirable for windowboxes on the north side of the house, for growing in sheltered nooks, and for warm, sheltered positions on porches. Several may be grouped together in a teninch pot very effectively, as they require but little room. They may be brought inside in the fall, and kept growing until they show signs of resting, when water should be gradually withheld until the leaves have ripened. The pots should then be set away in a warm, dry place-as a shelf in a closet-until wanted the following spring.

Such wonderful things have been accomplished in 
Gladiolus culture that one scarcely recognises the old favourite. All along the line, size, colour, texture, markings show the effect of a high state of cultivation and careful hybridising. The Childsi are, perhaps, the finest; while several of the strains of giant Gladiolus show wonderful size and colour. They increase rapidly, and one should buy a few bulbs each year so as to maintain a high standard.

When ready to plant, remove all loose husks, dead roots, and stalks, leaving the bulb clean and fair. Plant directly in the open ground, sufficiently late for frost to have gone by the time they are up. Plant the bulbs eight inches deep in fine leaf-mould, or a mixture of muck, loam and old manure, or even wellenriched garden loam. Planted deeply they will not need staking - an important point in growing Gladioli; nor will they be so much affected by cold, heat, or draught as in the case of shallow planting, and may be planted earlier and left much later in the fall, giving the bulbs more time to ripen.

They should be cultivated frequently during the summer or well mulched and supplied with water as needed. No seed should be allowed to form, as the plants make new bulbs each year, sometimes several, and that, with the production of flowers, is enough for one plant. A plant that seeds freely will not produce as many or as good bulbs. Take up in the fall before the ground begins to freeze, and put in a warm, sunny place for a few days to dry. Remove the stems 
by cutting off six or eight inches above the bulb, but do not attempt to pull or break them, as that will injure the new shoot which lies just inside the old stalk. Tie in bunches and hang in a dry, cool place, free from frost, or store in paper sacks.

Montbretias resemble the Gladioli in flower and foliage, but are very slender of growth. They throw long, graceful sprays of brilliant scarlet, orange, and lemon, very desirable for cut flowers. The flowers open successively, as do the Gladioli, and are in bloom a long time. They may be grown in the corners of the Gladiolus bed with good effect. The culture is the same, except that the Montbretias are not planted so deeply-about three inches. They multiply very rapidly-about fourfold, and are as easily cared for as the Gladioli.

Tigridias (Shell Flowers) are beautiful in colour, and odd in shape, and rather gorgeous in effect whether set singly or in groups. The colours are a pure white, white with lilac, purple and white, yellow and orange with dark spots, white with a brownish spot on a yellow ground, and rose colour. The flower remains open for only a day, but as there is always another to take its place it is not missed. They would better be started in the house in pots and bedded out when frost is past, as, planted in the open ground, they sometimes fail to appear. Lift and dry in fall and store in a dry, warm place during winter, examining occasionally for mould or grey lice. The leaf 
much resembles that of the date-palm, being ribbed and pointed at either end.

Summer-blooming Oxalis are very desirable plants for borders. They are extensively grown in parks and public gardens, but are little seen in private grounds. They are the most easily raised of all the bulbous plants and increase in a manner quite alarming, each bulb forming a long tuber resembling a white radish in general appearance, and covered with small bulbs-probably fifty-the top being crowned with one large bulb, the source of the season's florescence. These bulbs are not a solid body, as would appear at first glance, but are made up of hundreds of minute scales like a lily bulb. Added to its interesting character below ground is its rather remarkable performance above ground. It comes into leaf and blossom two weeks after planting, about the time the first tiny tips of other bulbs appear.

One great advantage of this precocity of growth is that Oxalis may be substituted when for any reason other border plants have failed to come up and it is necessary to replace them in a hurry. Often a hardy border plant winter-kills and one keeps waiting for it to start until it is too late to get plants from seed, then the little Oxalis comes to the rescue.

Buy them by the hundred and set about three inches apart and about two inches deep. Take up in the fall and put in a sunny place to dry, turning often; 
when dry remove from the centre tuber and sort, saving the largest bulbs.

\section{Crinums and Amaryllis}

4 OR the past year or so an unusual amount of interest has been shown in this magnificent class of plants, followed in many instances by grievous disappointment, as, led away by the glowing descriptions of the dealers, investments are made in bulbs whose proper culture is entirely unknown. It is to be regretted that dealers sending out bulbs requiring special treatment - as the Crinums-do not give instructions for their culture. It would save a vast amount of disappointment, complaint, and distrust. Unfortunately many florists do not themselves understand their requirements; they merely purchase the bulbs from other dealers, and publish trade advertisements and illustrations.

Seen in bloom under proper conditions and treatment it is not strange that florists wax eloquent in their praise, and invest heavily in bulbs which they sell to an ignorant and confiding public. There is, however, little difficulty in growing the Crinum-indeed, I know of no plant more easily grown, once it is understood.

Most of the complaints show that there has been no effort made to study the nature of the plant. A little study would show that an immense bulb like 
Crinum ornatum must have a generous supply of roots to sustain it; that these roots must have time to grow, commensurate with the length of time the bulb has been out of the ground, and that not much could be expected of it until these conditions were fulfilled. These facts are obvious from a study of the dry bulb, other facts are only arrived at after experience with the Crinum as a plant.

The root growth is quite in keeping with the size of the bulb; it forms great quantities of fleshy white roots as thick as pipe-stems, which are very impatient of disturbance and should be left practically unmolested for a number of years. When a bulb is prepared for market these roots are all removed. It is not strange that when called upon to rally from the shock of dismemberment and to replace the entire root growth it should sometimes fail to bloom as readily as expected. Often only a portion of the former roots start again, and this must be taken into consideration when anticipating bloom.

When a dry bulb is received from the florist it should be potted at once in a pot two inches larger in diameter than the bulb, that is, one allowing one inch of space between the pot and the bulb all around. Good potting soil, loam, leaf-mould, or muck, good sharp sand and old, well-rotted manure should be used. I do not think the muck absolutely essential, except in the case of C. Americana, which may be grown in pure muck, but good fibrous loam and sharp 
sand must be used. Place an inch or two of drainage material in the bottom of the pot, covering with sphagnum moss to keep the water from washing the soil into the drain and clogging it; fill within an inch of the top of the pot with soil; press the bulb into it, making a depression the shape of the base of the bulb and a couple of inches deep; line this hollow an inch deep with clean white sand, replace the bulb, water, and give a warm, sunny position. The bulb may be lifted and examined daily without injury, to note the root development and to watch for signs of bluemould, which is apt to attack the Crinum if slow in rooting and which, when it appears, should be carefully wiped off. As soon as the root growth has fairly commenced the bulb must not again be disturbed, as there is then danger of injuring the root. This inspection shows the root development the bulb is likely to make, and gives an idea of the probable florescence. The bulb is planted on top, and not in the soil, but if it makes the root growth it should that will hold it as firmly as though it were entirely embedded.

Usually a bulb will bloom in about three months from potting, sometimes sooner, but it is better to allow it a margin of time. Few leaves are made up to blooming time, but after the bloom has faded the foliage grows rapidly and, in the case of large bulbs, is really magnificent. When the foliage begins to fade and turn yellow at the tips the growth for the 
season is practically over, and water should be gradually withheld, and the plant allowed to rest. From this time on give only sufficient water to keep the plant from going dust-dry. Enough water may be given to keep the roots from shrivelling but not sufficient to induce top growth. Soon after starting it will be noticed, perhaps, that the bulb has shrunk and grown smaller and somewhat soft. As the foliage dies it becomes firm and hard again, the strength of the top has returned to the bulb from which it came, and it is at this period that it makes its own growth and prepares for another season of bloom, readiness for which it will announce by beginning to grow though water be withheld. The top earth-which should be dry at this time-should be removed as far as possible without disturbing the roots, and replaced with good, rich soil. Water freely, and when the buds appear give a little weak liquid manure once a week. The second blooming will be much finer than the first, as the plant has now sufficient root growth to support both stalk and blossom.

Should the bulb outgrow its quarters it may be shifted into a pot two sizes larger, care being taken not to disturb the roots. In this way the Crinum may be grown on from year to year, shifting when really necessary, renewing the top-soil each year without disturbing the roots and allowing it seasons of complete rest. This is the whole secret of Crinum cultureundisturbed root action and well-defined seasons of 
rest and growth. It requires a warm, sunny window in winter, and an eastern exposure in summer, where it will get the full morning sun and be protected from rough winds which injure the foliage. In protected situations certain varieties, as C. Kunthianum, hold their great leaves erect and are very fine; they will not do this when exposed to wind. Care must be taken to protect them from heavy rain, as water settling in the leaves sometimes causes the bulb to rot. I have lost some very fine specimens from this cause. A protected sand-box is an ideal place for them, as the evaporation from the wet sand supplies just the moist atmosphere they like. They may be wintered in a warm, dry cellar, but, if the cellar is at all cold or damp, it will be better to keep them on the back of the plant-stand or on a shelf in a closet where they may be inspected frequently.

Crinums are such expensive floral luxuries that it pays to take good care of them. Many varieties make few offshoots, and hence can never become cheap, but there is a distinct pleasure in possessing something rare and fine.

Unfortunately much confusion exists in regard to the two Crinums, Kirkii and ornatum, and the same bulb is often offered under different names. The dealers themselves seem to have no clear idea as to which is which. I believe, however, that ornatum is distinguished by a pink stripe through the centre of each petal, while the corresponding stripe in Kirkii 
is reddish-purple; these two are the most uncertain and unsatisfactory of all Crinums in the hands of the amateur.

C. Moorei, also often offered as ornatum or Kirkii, is one of the choicest Crinums and a native of South Africa. Its flowers, produced in umbels of from ten to twelve, are of a soft, delicate blush with a pink bar through the centre of each petal. It is deliciously fragrant, and the large bulb and handsome foliage much resemble $\mathrm{C}$. ornatum. C. erubescens is another rare tropical species, having umbels of as many as a dozen lily-like flowers of a claret-purple outside and a soft pink inside with filaments of dark red. It is a free bloomer of easy culture. C. Capense rosea has the reputation of being the most easily grown of any Crinum, and is quite hardy with protection as far north as St. Louis. It is said to winter in the cellar like a Dahlia. Farther north it should be given the same care in winter as other varieties. The flowers are numerous - white flushed with rose with a pink stripe through the centre, and more drooping than the flower in other species. C. scabrum, often called Christ and the Apostles, having thirteen flowers, produces an abundance of pale-green foliage beautifully waved and crimped. It has usually two flower scapes at once, flowers much like the old Annunciation Lily, but with a longer tube, so that the outer row droops. The six broad petals are pure, sparkling white with a light red stripe down the outside of 
each and a pink one on the inside. This is one of the most desirable varieties. C. fimbriatum-Milkand-wine Lily-is much like C. Kirkii in habit and appearance, but smaller, the flowers being but three or four inches in diameter, the foliage more erect and sword-like.

C. pedunculatum grows to a magnificent size, fine specimens averaging six feet in height and width. Its flowers, of pure white with purple anthers, are formed in umbels of thirty or more; the petals are narrow and the flowers exquisitely fragrant. It has a queer stump-like bulb which grows to an immense size, and is an evergreen, producing its flowers at intervals through the year like C. Americana, which has also pure white, fragrant flowers, the petals long and narrow. The latter, when in bloom, throws up one immense spike in the centre of the foliage, giving the plant the appearance of a great rounded bouquet. It is a native of the Florida swamps, and should be grown in muck with considerable moisture, blooming best when pot-bound. C. grandolia, or augustum, is the finest of all the Crinums: one grown in Florida "with leaves six feet long and correspondingly wide, with a crown of bloom the size of a bushel measure." Its umbels of flowers, thirty or more in number, with broad petals eight inches long, make a magnificent display. The buds are a purplish-red, the flowers, when open, a blood red outside and a delicate, satiny flush inside. The bulbs grow to an immense size. 
C. Kunthianum, another of the large-growing Crinums, is highly to be recommended for amateur culture, being much more easily managed than either ornatum or Kirkii. It is evergreen, and has broad strap leaves of a bluish green that, in the house, are held erect, and for this reason it presents the finest appearance of all Crinums. It throws up a tall spike crowned with ten or twelve large, lily-like flowers of a rosy white with crimson stripes through the petals.

The general treatment of Amaryllis is the same as for Crinums. Disturb the roots as little as possible, and give as complete seasons of rest as the plant seems to require. When it is apparent that they are trying to rest they should not be forced to grow, but aided to sleep by judicious withholding of water, tempering of the light, and the like. Evergreen Amaryllis, like the Aulica platypetala, do not need these periods of complete rest, but they need a partial rest, and as long as no new leaves appear should be watered moderately and the roots left undisturbed as long as possible. Remove all offshoots that have grown to any size when the plant starts to grow and the top-soil is being renewed, and pot them off in small pots an inch larger than the bulbs. The number of fine hybrids have increased so rapidly of late years that it is impossible to describe them separately, as many of them are flaked and splashed with colour in a wonderful manner. Of the old-time favourites it is 
doubtful if any excels the A. Johnsonii, and a collection of Amarylli might well begin with this.

Tuberoses should be started in a warm place where they will not be exposed to draughts or chills. Before potting, take a sharp knife and remove all the old root and hard substance about the base, leaving but a thin layer below the bulb. Unless this is done, growth will be either delayed or prevented, as the new growth cannot push through this hard substance. Pot singly in four-inch pots and keep moist and warm until growth begins, when they may be given a position in a sunny window, and encouraged to grow until time for planting out in the open ground, after all danger of frost is past. If it is not desired to plant directly in the open ground they may be shifted into six- or eight-inch pots and plunged in the ground. They must be plunged to the brim, or over, and will require more water than when growing in the ground. If they are still blooming at the approach of frost they may be lifted and removed to the house. Others that have been bedded out may be lifted, potted, and brought in, and will bloom as freely, though not as quickly, as those in pots. Disturbing the roots does not seem to interfere at all with the process of bloom.

The double pearl Tuberose blooms but once, and it is hardly worth while, unless one has much room and time, to try to bring the small bulbs forward to the blooming stage, as they must be cultivated for two or three summers and cared for for as many winters. 
The variegated leaved, however, blooms from year to year, and should be taken up in the fall and stored in a warm, dry place. This variety is single, but very fragrant and pretty. Tuberoses do well in the Gladiolus bed, and their pure white spikes are very attractive among the more brilliant flowers, but they should be planted in clumps and not scattered among the Gladioli. 


\section{Chapter FOUR'TEEN}

\section{Aquatics}

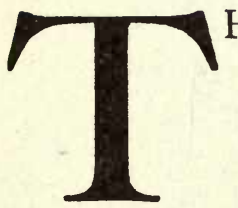

HERE is special delight in the cultivation of aquatics, due partly to the novelty of the work, and partly to the feeling of rest associated with this particular branch of floriculture.

One can rarely go into the garden in the early summer without seeing something to do, a plant to be trimmed, or a vine the wind has blown down, and always plants needing water. When the lily pond is reached, be it natural or artificial, one feels that here there is rest, for an established lily pond seldom needs care. In small tanks the water must be renewed occasionally, but once a week will be sufficient.

Probably the simplest way of constructing a lily pond where the lay of the land and soil are favourable, is to mark out a desired area, remove about two feet of soil and turn the cattle on it. With stiff clay soil this will in a few months give a bottom sufficiently hard to hold water. Spread several inches of muck and old manure on this prepared ground and the place is ready for the water, which may be piped 
from a well or supplied by a wind-mill. Such a pond has this advantage over one made of cement, that semi-aquatic plants, such as Reeds and Bamboos, Japanese Iris, Cardinal Flowers, and the native Flame Lily may find a place on its banks and add greatly to the beauty of the pond.

When one is so fortunate as to have a little stream flowing through a corner of the grounds it can be diverted to form a pond with sufficient current to prevent stagnation, yet not enough to interfere with the growing of water-plants. By selecting a low spot beside the stream very little excavating will be necessary, and the nature of the soil and force of the water will decide what, if any, barrier may be needed. Should the stream be some distance from the house a shrubbery, hardy perennials, and an occasional tree may lead up to the pond. If this is so fortunately placed as to be on the north side of the grounds, so that the sun lies on it when seen from the house, the effect will be greatly heightened by a clump of evergreens on its northern shore, making a background to arrest the eye and focus it on the lily pond. Where the landscape is limited, a group of tall Bamboos is effective at this point, and Japanese Iris may have a place in the foreground; Sagittarias and ornamental grasses may also be used with good results.

Where one lacks the advantage of natural conditions a cement pond is a good substitute. It may be expensively constructed with piping for water, 


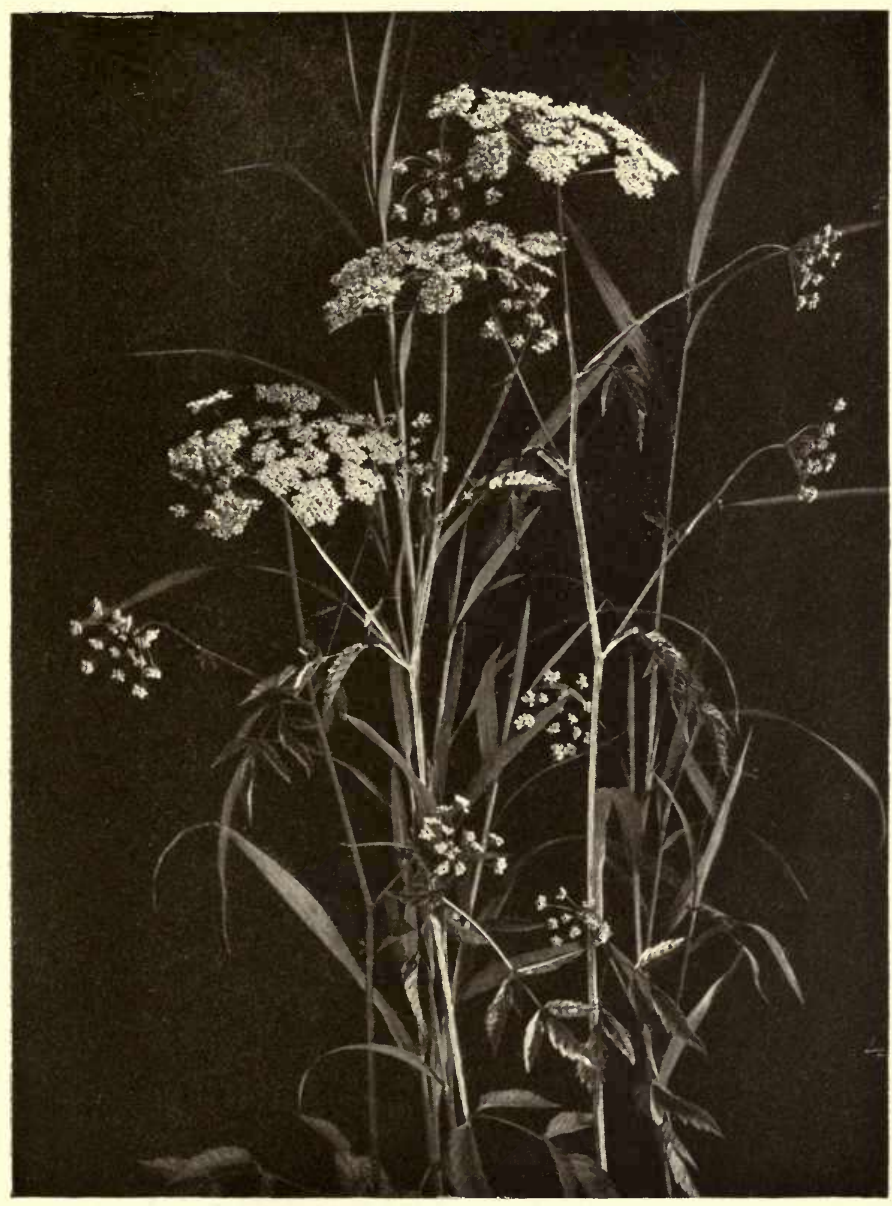

WILD WATER FLOWERS FOR EDGING LILY-POND 


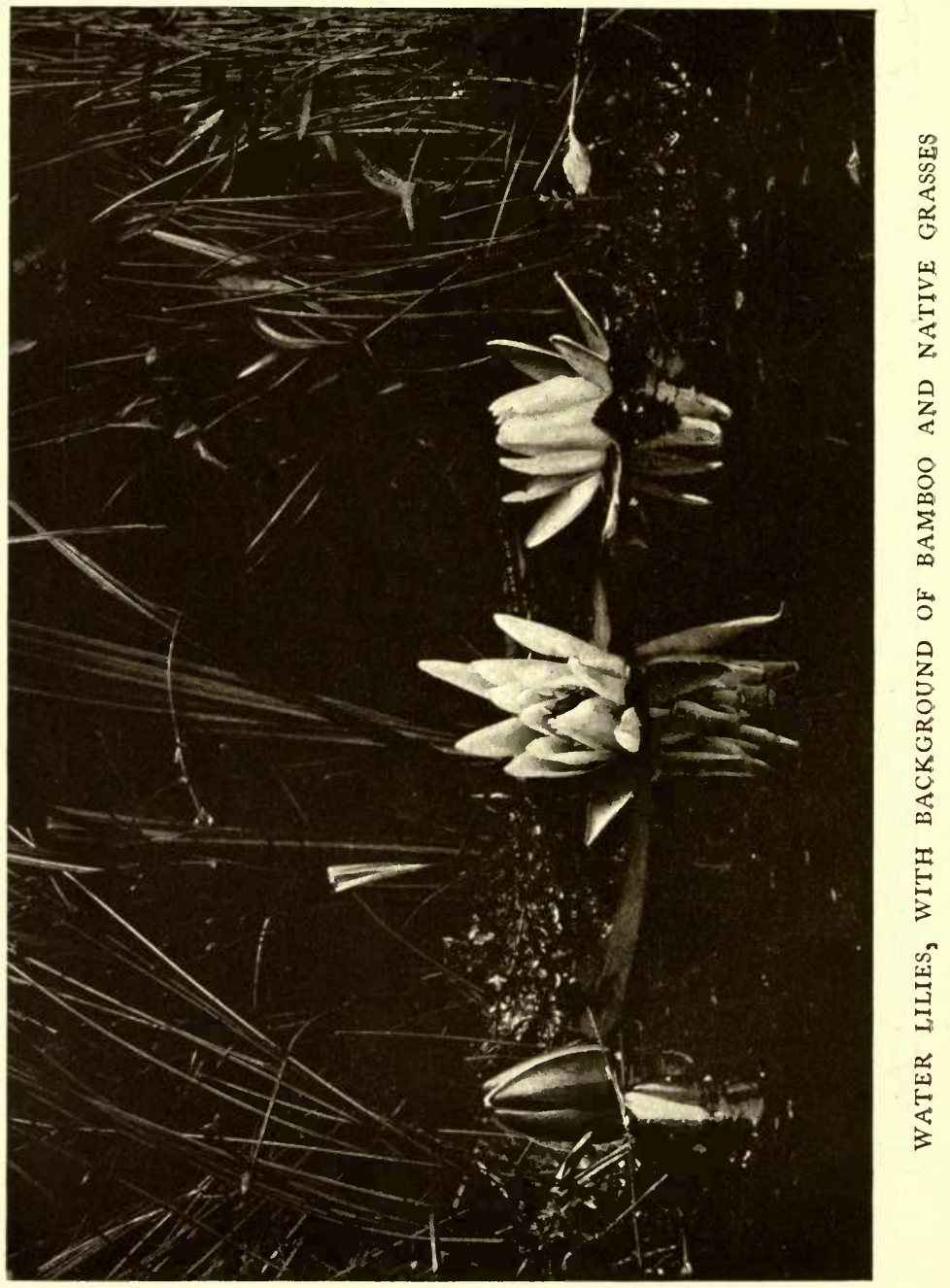


drainage, etc., or it may be made at a cost of from five to thirty dollars, according to size. Five or six by eight, or eight by ten or twelve feet, will be found convenient sizes, as they will admit of reaching the centre. The basin should be about two feet deep when completed, and if of clay the soil should be wet and made as hard and smooth as possible. If the soil is loose and sandy it will need a coat of clay before applying the cement. This may be done by mixing the clay with water to the consistency of mortar and applying in any convenient way. Allow this to dry before using the cement. A neat curbing will greatly improve the appearance of the pond.

When the cement is perfectly dry, place six inches of old, well-rotted manure in the bottom of the basin, and cover with eight or ten inches of muck. Make this smooth and level, and cover with one or two inches of clean white sand to keep the water clear and sightly and prevent the muck from rising to the surface. Fill with hose or watering-pot, letting the pond overflow until the water is clear and the sand firm and smooth, when it is ready for plants.

When a permanent bed of this kind is out of the question, a large zinc tub, or half a hogshead, will make a small water-garden. These would better be raised somewhat above the surface of the ground to protect them from decay. Three small five-inch drain-tiles laid sidewise make a good foundation, 
and a very pretty effect may be obtained by piling rough stones around the tank. Fill in with earth and cover with vines and plants suitable for a rockery. If a tall Bamboo, or even a fine clump of Papyrus or Umbrella-plant can be grown on the north side, so as to overtop the tank without shutting off the sunshine, it will add much to the general effect. The Lily pond should have full sunshine, but be protected from rough winds, as the leaves of large Lilies that stand well above the water are easily injured. The Egyptian Lotus is the finest of all Lilies suitable for growing in small ponds or tanks. These plants should be purchased from growers, as they do not seed in this country and the imported seed is uncertain. One plant is sufficient for a tub or tank, as they increase very rapidly and do better when not crowded.

One of these Lilies may be placed in the centre of a small pond of ten feet or more, and other Lilies grouped around the sides. Hardy Nymphæas may be planted in the soil of the pond, while the more tender Zanzibarenses should be planted in twelveinch pots and plunged in the tank, as these are not hardy like the Nelumbiums, to which class the Lotus belongs. Both the Egyptian and the American Lotus are quite hardy in the open ground with a protection of rough litter and boards. An interesting peculiarity of the Lotus, by which it may be distinguished from other Lilies when quite small or out of bloom, is that water splashed on the leaves always rolls up into little 
drops like quicksilver instead of spreading over the leaves, as on Nymphras and the like.

There are several varieties of Nymphæas suitable for amateur cultivation-the Cape Cod Water Lily, with its large, cup-shaped flowers of a lovely pink; $T$. Richardson, probably the finest white variety; our native Nymphæas, and the lovely Zanzibar Lilies in blue and crimson. These last are very easily raised from seed, which, if planted early in February, will give bloom by July, and may be wintered in a warm, dry cellar. In a cold, damp cellar they rot. If grown in tubs drain off the water at the approach of cold weather, remove to the cellar and keep merely moist. If grown in ponds it is better to plant them in pots, which may be lifted and brought into the cellar for the winter. Into a large bowl or crock put a few inches of rich soil, cover with clean white sand and turn on tepid water until it runs clear. Sow the lily seed on the surface of the water; it will go to the bottom when entirely wet and be more evenly distributed than would be the case were it sown on the soil and the water turned over it.

Through the clear water the whole process of germination may be watched. In six days a threadlike sprout will have started from the swollen seed; in six days more this thread-like shoot changes into a tiny dart-shaped leaf; in another six a true leaf comes upon the scene, a very small lily-pad, but giving promise of great performance. 
When the dish becomes crowded transplant into other dishes, keeping plants out of water as short a time as possible. When the nights are warm-at least $60^{\circ}$-plant out in tubs or ponds. For the first year an eight by ten foot pond may have a Nelumbium in the centre, two or three Zanzibar varieties on either side, and pink and white Nymphæas at the end. If the plants have done well reduce the number the second year.

Water Hyacinths are found interesting principally because they are more or less of a novelty even at the South, having been introduced from Venezuela about fourteen years ago. This plant has already proved itself a nuisance in the Florida rivers, seriously interfering with navigation and calling for appropriations from the Government for its destruction. In house or garden cultivation the roots increase rapidly. A small plant set in a tub in full sunshine in May will fill it by August. The leaves form rosettes and expand at the stem into a sort of bladder that supports the plant on the surface of the water. The roots trail in the water until the plant is ready to bloom, when they enter the soil. The flowers are a pleasing shade of lavender with a yellow centre and form in spikes like a Hyacinth. Paris green must not be used in the water where the Hyacinths are grown, but lumps of charcoal and a small quantity of kerosene may be substituted.

A few Water Poppies holding their bright yellow 


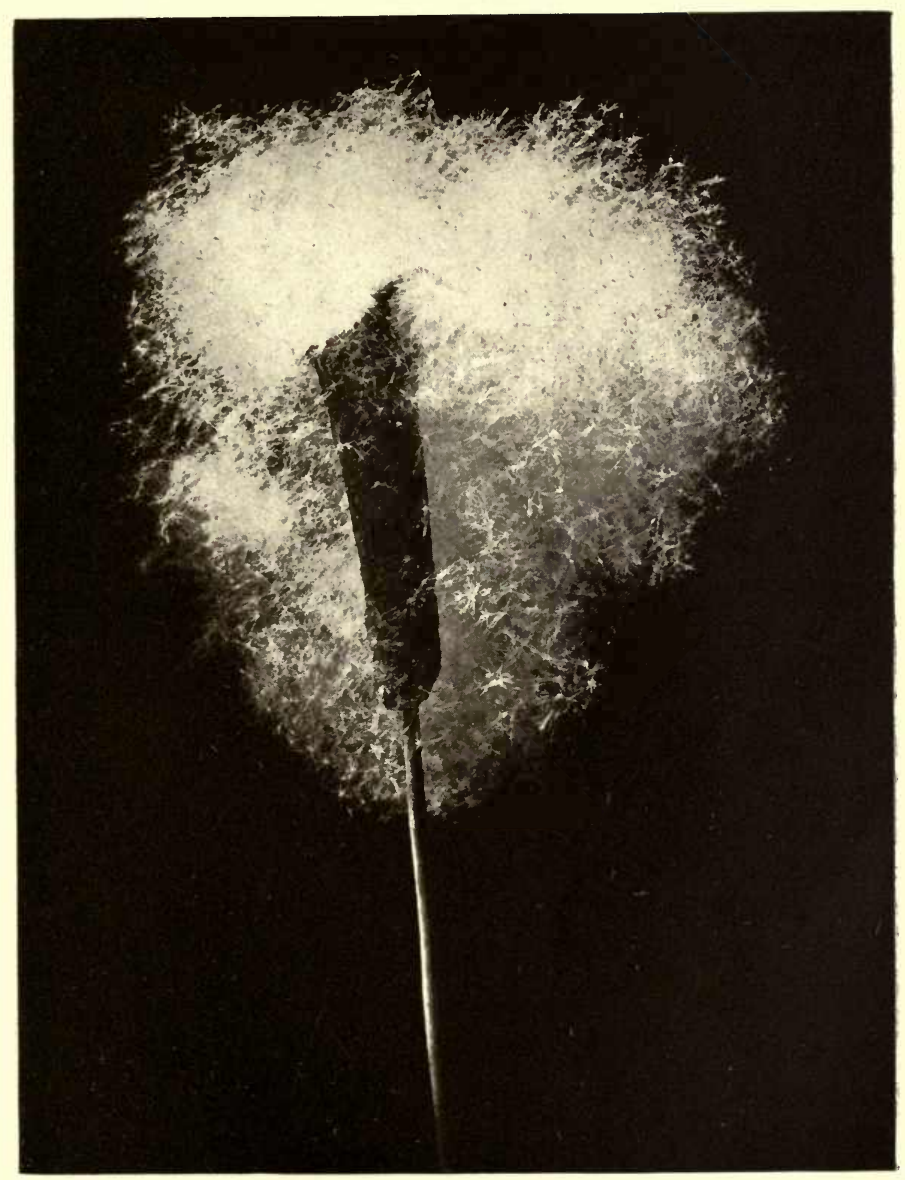

A FULL BLOWN CAT-TAIL

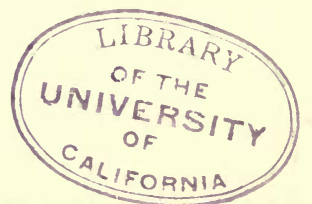




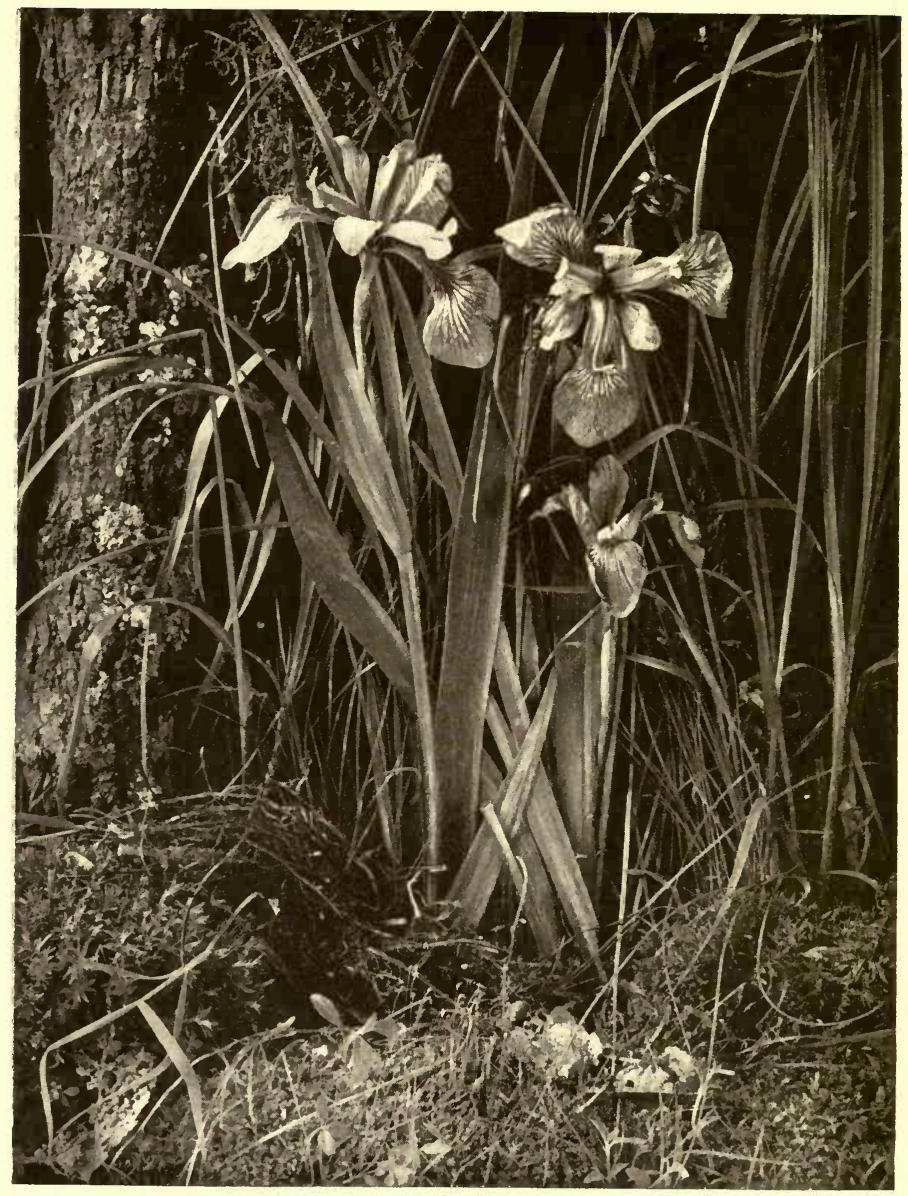

NATIVE PLANTS EDGING A NATURAL WATER GARDEN 
cups well above the surface of the water are always attractive, and Parrot's Feather trailing over the sides of the tub gives a bit of tender green through the summer, but the rockwork, with ferns and plants and a tall reed or two, makes a much tidier appearance. The Papyrus-the plant from which our first paper was made-is very effective and will grow wherever a Canna thrives, though it prefers a low, damp soil. It must be wintered in greenhouse or cellar. A welldeveloped clump will grow to a height of ten feet. Several varieties of Bamboo, to be had from South Florida nurseries, will do well in the North in summer and stand a considerable degree of cold. Bambusa arundinacea is a magnificent quick-growing sort from forty to sixty feet tall at maturity, and will stand considerable frost. B. aurea and B. Metake are hardy with good protection at the North. B. Metake is a handsome evergreen species of considerable decorative value for indoor culture, growing six feet tall with large, handsome foliage, while A. falcata is a pretty variety with the tiniest of leaves. Bamboo requires an abundant water-supply, and is therefore most suitable for the borders of natural ponds, or low, damp spots on the grounds.

The objection raised to ponds is that they breed mosquitoes and malaria and are likely to become offensive. So will anything that is neglected, but there is not the slightest reason for the lily pond becoming a nuisance in any way. A small amount 
of Paris green in the water-a teaspoonful to an eight-foot pond-will keep it perfectly clear and sweet and prevent the formation of green scum and moss, so offensive in stagnant water, and the breeding of mosquitoes. Or a little charcoal and kerosene will give the same results. 


\section{Chapter FIFTEEN}

\section{The Care of the gummer lioge=bed}

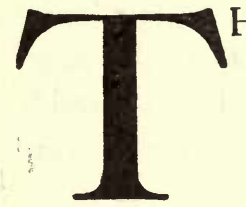

HE old-fashioned June Roses, with their long season of flowerless bloom, hardly repay the trouble of raising. The hardy perpetuals and hybrid Teas may now be purchased so cheaply that, even though a large proportion of them should not survive the winter, a small outlay will replace them. The thorniness of the old hardy June Rose adds greatly to the labour of caring for them, and this alone would lead some to discard them.

If, however, one clings to the old-fashioned Roses from economy or sentiment, they should be grown to their fullest possibilities by pruning, cultivation, and liberal mulching with coarse manure in the fall, and lawn clippings in the summer. Pruning should be done late in the winter or early in the spring before the sap begins to run. Remove all weak and straggly branches, cutting back the new growth to the first strong leaf-buds on the shoot. It is well to cut out the centres, as the new growth will quickly fill the space and be stronger and better in every way for the 
removal of the old wood. It will also leave less wood and briers to collect and hold dead leaves and grass during winter, which must be taken out, at the expense of bleeding fingers, in the spring. Bushes which grow upright with little wood at the base are more easily cared for. Only strong, new growths should be left, which will break freely and give firm new wood, producing fine flowers. Breaking means the starting of young leaf-buds at the axils of each leaf, which sprout and form new branches. It is the new wood that bears the flowers, so that its growth should be encouraged. The fewer shoots allowed to grow the finer will be the flowers.

Cultivate thoroughly in spring and fall and give a heavy mulch of lawn clippings during summer. Mulch heavily with coarse manure in the fall, digging in the best of it in the spring. It is not necessary to give winter protection, though it is best to wrap the tops with straw when exposed to cold winds.

Hardy climbers should have all weak shoots removed, and branches that are too long shortened. Thin out a part of the canes to give room for air and growth, and remove all wood that has grown too hard to break, as it will produce no new wood and is only an incumbrance.

For the summer rose-bed nothing equals the $\mathrm{Hy}$ brid Teas, which bloom from June until frost. If young plants are purchased in the spring they may be bedded out at once, if sent by express with the ball of 
earth about their roots intact. If sent by mail it will be better to pot off in three-inch pots, and set in a cool, rather shady place for a few days, bringing gradually into the sunshine until they have become established, when they may be turned out into the open ground without disturbing their roots. If planted at once in the open ground, the more delicate ones would be likely to perish.

Give the rose-bed a sunny, protected situation, using a soil of good garden loam, clay, and old, wellrotted manure, made deep and mellow. If the plants are the small mail-order size set one foot apart each way, planting according to directions for transplanting, and make the soil very firm and hard about their roots. Cultivate frequently, or mulch with lawn clippings, working them in as they decay. Liquid manure must not be given until the plants are growing vigorously, when it may be applicd once or twice $a$ week. More plants are injured by the injudicious use of fertilisers than in any other way.

If two-year-old plants are purchased, set from eighteen inches to two feet apart each way. See that each plant has a zinc or wooden label securely fastened to it, or, what is better, make a list in their regular order, or a diagram of the bed in a notebook. This permanent memorandum will enable you to be sure of the name of any particular Rose.

Cut Roses with a liberal amount of the stem, and only enough pruning will be needed to keep them in 
good shape and remove any weak growth. It is a good plan to cut them down to a bud that will be likely to throw a good shoot. Hardy Perpetuals or monthly Roses often fail to give more than a few early spring flowers at the tips of the branches. If the plants are in good condition, and the branches of some length, peg the ends down to the ground with a clothes-pin or stick, as the tendency in Rose growth is for new wood to start from the highest point. Bending the end down brings the highest point at the middle of the branch, which will then break and bloom.

Roses, especially the old hardy kinds, will often refuse to bloom, though well cared for and sufficiently pruned. In such cases root-pruning may be resorted to by cutting down on two sides of the plant with the spade and severing a part of the roots. This will often induce bloom when all other methods fail. Plants occasionally run to roots as well to tops.

So many and varied are the insect enemies that a hardy Rose, with even fair foliage, is rare during the season of bloom, unless ceaseless warfare has been waged from the first swelling of the buds. Slugs, rose thrip or hopper, and rose-bugs make the life of the rose-grower a weariness. On this account alone I would recommend discarding the June Roses in favour of the Teas, which are fairly free from these pests. Their dark-green, healthy foliage is a striking contrast to the worm-eaten, rusty foliage of the hardy 
Rose. The only weakness they show is an occasional tendency to mildew, and this may be avoided by giving an airy, sunny situation, setting far enough apart to insure free circulation of air, and watering early that the foliage may dry before the chill of night. The remedy is flowers of sulphur dusted over the leaves.

Rose-slugs are small green worms that feed on the foliage, lying on the under side of the leaves, which they roll around them or draw together with a slight web. The remedy is to spray the under side of the foliage with kerosene emulsion, or with hot water heated to $140^{\circ}$, being careful to reach every part, or to go over the plant leaf by leaf, pinching the leaves between the fingers and crushing them. The rose hopper, or thrip, is a small, yellowish-white insect feeding on the under side of the leaves, sucking their juice and causing them to turn yellow. The best remedy is the whale-oil solution sprayed on the under side. For rose bugs, or beetles, spraying with Paris green is quite effective, but it must be used promptly, as the amount of injury they can do in a short time is remarkable. After using an insecticide, the plants should be thoroughly sprayed with clear water, and if treated with Paris green label them, that no one may be poisoned by eating the rose-leaves. Roses for pillows should not be gathered from plants that have had any kind of poison used on them.

Roses kept in the house during winter are some- 
times attacked with green lice. They may be treated with tobacco in some of its forms, or with hot water - dipping the entire plant in a pail of water heated to $130^{\circ}$. I prefer the hot-water treatment, as it leaves the plant clean and invigorated. Few, if any, plants are injured by it, and most are benefited. Where there is any question of the effect on a particular plant a single branch may be dipped as an experiment. It is difficult to make any choice of Roses where all are so beautiful. American Beauty is probably the most popular crimson Rose to-day. The Bride stands first among the whites. Kaiserin Augusta Victoria is a most desirable hardy white, and the new rose, Virginia R. Coxe-also offered under the name of Gruss an Teplitz-is one of the most desirable reds; a profuse and constant bloomer with loose-petalled, medium-sized flowers of the richest scarlet, shading to glowing velvety crimson. Among the climbers Mrs. Robert Perry is the finest, an immense, pure, creamy white, quite hardy, and a free and constant bloomer, valuable for cut flowers.

If one has room for a hundred varieties it is easy to select that number with the certainty that there need not be a poor Rose among the number. 


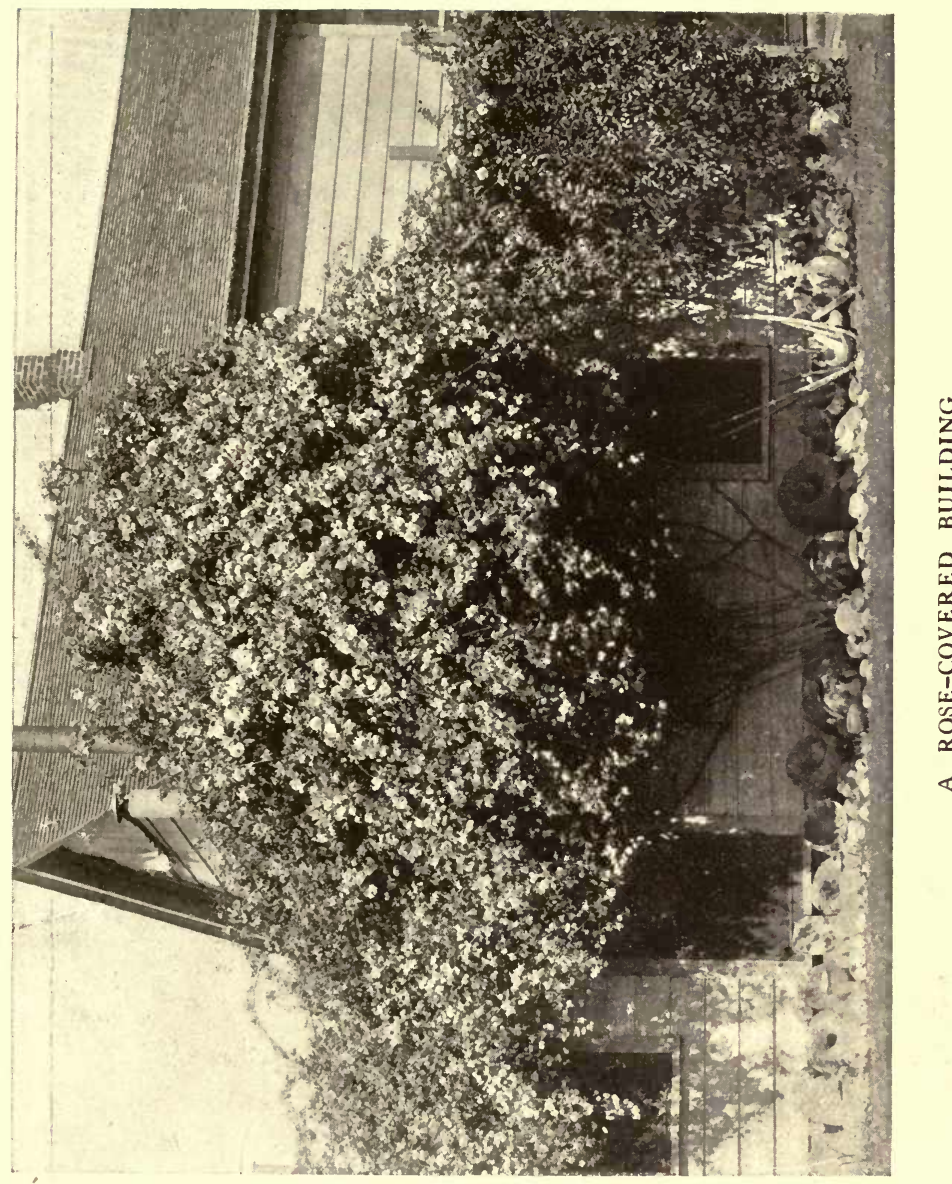




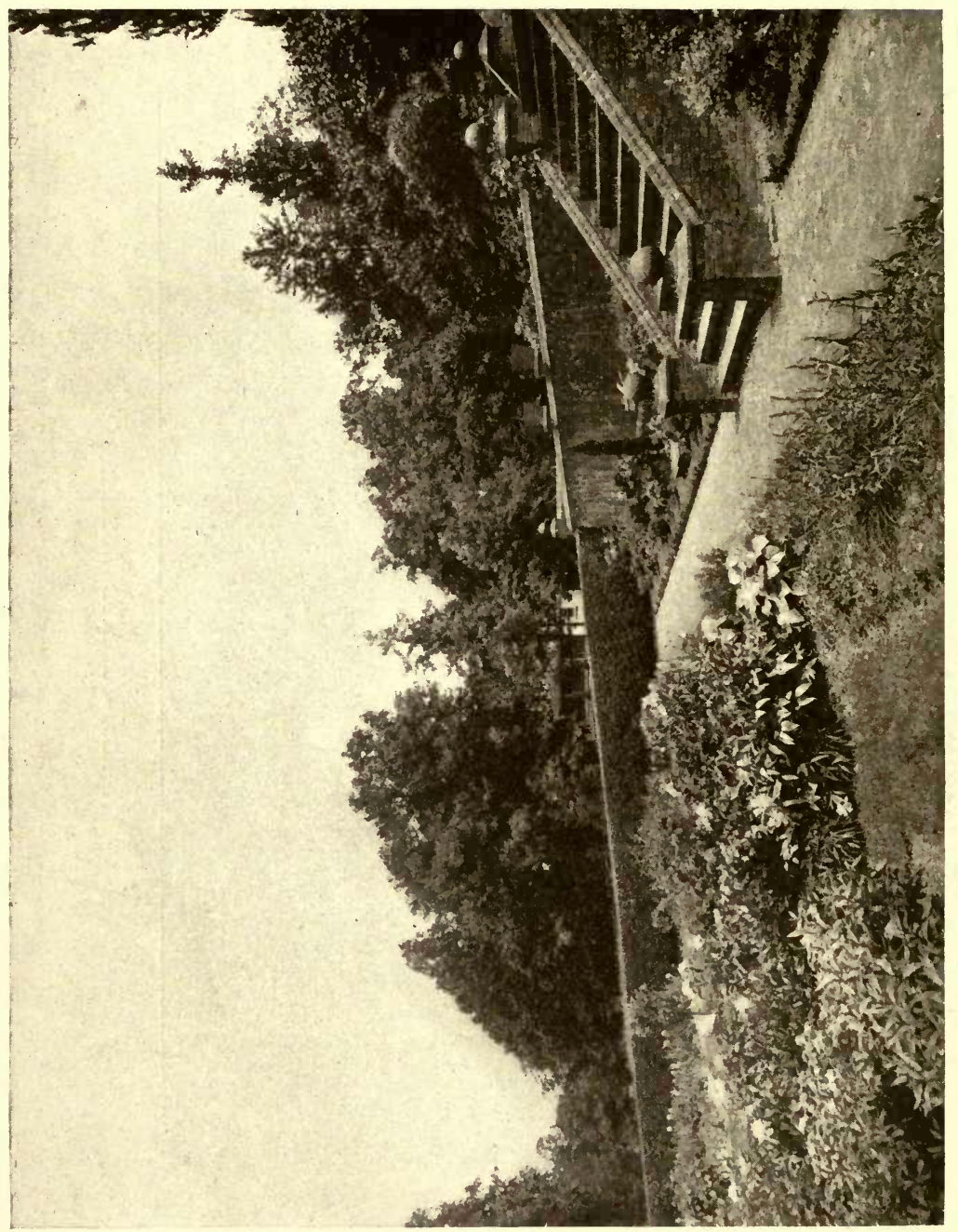

㲾

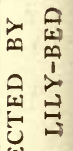

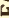

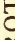

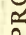

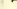

命

I

(5)

$z$
0
0
0
0
0
$\alpha$ 


\section{Chapter SIXTEEN

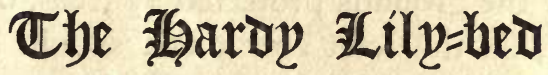

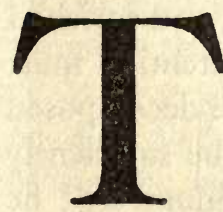

HERE is no better investment for the garden than a bed of hardy Lilies, which should be started in the fall as early as the bulbs may be had. This is often later than is desirable, but the matter is entirely beyond control. The best that can be done is to get orders for foreign-grown bulbs placed early in the fall. It is not necessary to wait for the new catalogue, as the old will give the varieties and approximate cost. The main thing is to get in the order early that it may be filled promptly when the bulbs arrive. Orders received last are filled last. This means not only considerable delay, but second choice in bulbs; the first-comers secure the best, the last must take the cullings.

Having ordered your bulbs, proceed at once to make your beds. Better results are obtained by planting Lilies in beds with fibrous-rooted plants, hardy shrubs, and perennials that do not need frequent disturbing. The Lily is very impatient of moisture, and water standing around the roots in winter is absolutely fatal. A raised bed of Peonies affords favourable 
conditions, provided there is sufficient room between the plants for the Lilies to increase from year to year, as once planted they should not be disturbed. If the Lily-bed is to be by itself an angle of a building, or a portion of the grounds protected by trees, or adjacent shrubbery, on the west and north, should be chosen. Such a site, if well drained, will give good results. The bed should be dug deep and mellow, and enriched with old, well-rotted manure. Strict attention must be paid to this point-only old, well-decomposed manure must be used. The bed should be sufficiently rounded to shed water. Lilium candidum will be ready to ship in August, and should be planted as soon as received. All Lilies are greatly injured by exposure to air, and if it is necessary to keep them out of the ground for any length of time they should be well wrapped in tissue-paper, or otherwise protected. The Japanese protect their great auratum Lily bulbs from the air by encasing them in a ball of clay before starting them on their long journey to the far West. Candidum Lilies make a fall growth of leaves, and must be planted early; no other Lily is as hardy and satisfactory with us as this. They should be planted four inches deep and a foot apart each way, that they may have room to increase, and left undisturbed for years. The soil may be made very rich with manure, but none of it should touch the Lily bulbs. Make a hole of sufficient depth and size, put an inch or more of sand on the bottom, place the bulbs on this and fill 


\section{Sixteen]

up with the sand, packing it closely all around the bulb.

Of the Japanese Lilies, rubrum is most easily grown here and should be planted eight to ten inches deep. Planted deep they are not injured by thawing and freezing, but when too near the surface the frost often throws the bulbs out of the ground. Lilies are not injured so much by freezing as by sudden and frequent thawings.

As long as the rubrum is doing well it should not be disturbed, but if it suddenly fails to grow and bloom the bulbs should be taken up when dormant, and cleansed. Remove all decayed scales and look for worm-nests, which are usually the source of the trouble. Ants sometimes make nests in the Lily bulb in the spring, and cause the top to decay. When this occurs it should be lifted, cleaned, and reset in a place free from ants. The greatest care must be exercised in cleaning bulbs not to injure the sound scales, as that will only induce further decay.

All the speciosum Lilies are exceedingly beautiful. L. Album is one of the finest; its reflexed flowers are a clear, sparkling white with a green band through the centre of each petal, and a peculiar glistening appearance, as though covered with water. It is one of the most easily grown of the speciosum family. S. Roseum is another handsome variety, white flushed with rose, and with dull crimson spots on the white ground; while S. rubrum has large reflexed petals of 
frosted white, heavily bearded and spotted with rich crimson, with many glistening points of white. Aside from the speciosum Lilies there are many other fine Japanese Lilies, the auratums easily leading in size and beauty. While Krameri is a tube-shaped Lily of a soft pink; longiflorum has lovely trumpets of pure white; the wonderful Lilium giganteum, six to ten feet high, sends up immense clusters of twelve to twenty creamy white flowers, with purple throat. Washingtonianum is another tall variety bearing large clusters of delicate white flowers spotted with black, and the grand and rare Brownii shows a chocolate-purple outside with a creamy interior. The list is long, but with a generous planting of well-selected varieties a succession of bloom may be had from the first blooming longiflorums and candidums in June until auratum and the late speciosums cast their ivory petals in September.

The general treatment of all is the same: deep planting, keeping the manure from actual contact with the bulbs by packing in sand; well-drained soil and the presence of fibrous-rooted or perennial plants near enough to absorb the surplus water from the soil. During the hot weather, give a heavy mulch of lawn clippings brought well up around the stems, and water as needed. If planted deep they will hardly require staking, as the stalks send out surface roots which not only afford nourishment, but also act as a brace to the plant and hold it firmly in its place. 
A heavy mulch of old manure and rough litter should be given in the winter, and the bed protected with leaves and evergreen boughs, or anything that will shed water.

Spring-planted bulbs rarely do well. It is better to plant after severe cold weather sets in than to wait until spring. As long as the ground can be worked they may be planted safely, but they should be set eight or ten inches deep. I have planted them late in December-when the ground had to be broken with an axe-and have had excellent success.

The planting of hardy Lilies should be done on a scale limited only by one's means and the ground at command. A few new and rare sorts should be added every year. In this way a magnificent collection will, in time, be acquired, as they increase very rapidly under favourable conditions, and the larger the clumps of one kind the finer the effect, so that each variety should be given abundant room to spread and develop.

It is often stated that Lilies left to themselves place their bulbs near the surface. Such bulbs are the small ones that form on the blossom stalk above the main bulb, and lie near the surface from force of circumstances. The main bulb sends its offshoots deep in the ground, as in the case of our native Lilies, which are almost impossible to dig. Especially is this the case with the native Flame Lily, the bulb of which I have never been able to reach with a trowel. Travellers in Japan report various native Lilies growing in 
forests among the interlacing roots of the trees, quite out of the reach of any small tools. There the auratum Lily grows on wooded hillsides where the drainage is perfect, and the falling leaves give a deep mulch at all times, and supply the best of nourishment, leaf-mould, and the roots of the trees absorb all superfluous moisture. 


\section{Chapter SEVENTEEN}

\section{The Care of Cannas, Caladums, 葘ablías, and Otber bulbs 进uring 2 sinter}

Fall Bulbs, Tulips, Hyacinths, Crocus, Scillas, and the Like

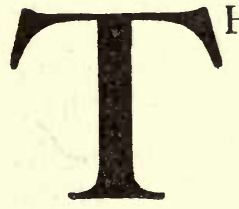

HE first hard frost in September-about the 2oth inst. at the North-is usually followed by a few weeks of mellow fall weather. If one has been so fortunate as to have saved Cannas, Caladiums, and other tender bulbous plants by night protection or by turning the hose on very early in the morning before the sun reaches them, they will grow and ripen well in these last warm days. These sudden falls of temperature usually find the gardener unprepared, and unless water is at hand plants will be cut down by frost. When this happens remove, with a sharp knife, the frozen portions, and consign to the compost heap. If allowed to remain, these not only give the yard a most untidy appearance, but the decay 
is likely to extend to the bulbs. The plants may then be left to ripen in the ground for several days, according to the weather, or the necessity of preparing the ground for other plants.

Dig all roots to be saved on a warm, sunny day, and dry in the sun for several days if the weather is fair and warm. Cover with blankets at night or leave them on the floor of a sunny room until the earth about their roots is dry, pack in boxes of dry earth or sand, and store in a dry, frost-proof cellar.

Dahlias and the common tall Canna are easily wintered in a warm, dry cellar. The large Orchid-flowered Cannas are much more difficult to winter, and are very apt to dry-rot under the most favourable circumstances. I have found laying on the ground (under the steam-pipes where they are run outside the cellar) and covering with dry earth a very good way of handling them. They should be examined occasionally, and if they seem too dry sprinkle with water. If the Caladium bulbs show any decay of the centre-shoot all the decayed parts should be pulled off down to sound tissue. Parts of Cannas broken in digging should be removed with a sharp knife. Where there is but a small quantity of roots, shave off the dirt and wrap the tuber in tissue-paper. Store on a shelf in a closet, or other convenient frost-proof place. There is no more uncertain root to carry through the winter. Florists often lose their entire stock by decay or dryrot, and were it not for this the Canna would soon 
become a drug on the market, and only novelties have a sale.

Dahlias are much more easily wintered, doing well in any cellar that will keep potatoes in first-class condition. All roots wintered in cellars should be placed on elevated shelves or tables away from the low temperature of the floor-on a swinging shelf, if the cellar is frequented by rats and mice.

Gladioli will keep perfectly if stored in flour-sacks and hung from a beam or post near the ceiling. Montbretias may be wintered in the same way.

When the Cannas, Caladiums, and other summer plants are out of the way the beds may be prepared for the fall planting of bulbs for early spring blooming. The vacant foliage-beds on the lawn offer the best place, as the bulbs will have played their part and passed on by the time these are needed again for the summer occupants.

If the beds have been lowered owing to limited water-supply haul on a few wheel-barrow loads of very old manure and earth, and mix thoroughly with the soil, raising them sufficiently to shed water. If permanent bulb beds are preferred (which may be planted with annuals in the summer) choose an exposure slanting toward the south, if possible, as this will insure earlier flowers. See that the soil has good natural drainage, or, if this is lacking, supply it by excavating to a depth of eighteen to thirty inches, and placing several inches of broken stone or crockery in the bot- 
tom for drainage. Return the soil to the bed, making it mellow and fine. The earlier the bulbs are planted the more roots will be started before the ground freezes, but late fall or winter planting, providing the ground is not frozen, is preferable to spring planting. Spring-planted bulbs rarely amount to anything, having lost much of their vitality by being so long out of the ground.

A bed facing the south is warmer and earlier than any other, hence it is sometimes liable to a set-back -if not actual injury - from a sudden sharp frost after the plants have started in the spring, and the litter should not be wholly removed until it is entirely safe to do so. An ideal bed for early bulbs would be one on the south side of the house, sloping slightly toward the south, with a frame around it somewhat higher at the back, over which a canvas attached to hooks could be drawn on cold nights and days. The frame should be made so that it could be readily lifted on the approach of warm weather.

Hyacinths, Tulips, and Narcissi look far better when planted each in a bed by themselves, as they are not at all in harmony. Plant Hyacinths seven inches apart and four inches deep, either in beds of vivid colours without other order than a regular distance apart, or according to some colour arrangement or geometrical design. Tulips should be planted four inches apart each way and four inches deep. A good arrangement is to draw lines across the bed forming 
squares-four inches for Tulips, seven for Hyacinths -and set a bulb at each corner. The centre of the square may be filled with Crocus or Scillas, which will have finished blooming before the larger flowers are out. Only Tulips of the same height and season of bloom should be set together.

Scillas and Crocus together make a bed that can hardly be surpassed in bulb planting. The effect is best where only the white Crocus is blended with the blue of the Scillas.

Protect the bulb beds with rough manure, leaves, and evergreen boughs during winter. Remove the protection gradually in the spring, and leave the finest of the manure to enrich the soil.

When through blooming in the spring, and the foliage has ripened, the bulbs may be lifted, dried, and stored away in a cool place until fall. All these bulbs increase rapidly, both by multiplying and by seed. Neglected beds of Tulips seem to multiply and perpetuate themselves indefinitely, but the new plants will be found to be all from seed, as the Tulip forms its new bulbs at the base of the old, and if they were not frequently taken up and reset they would grow so deep in the ground that all the strength of the plant would be exhausted reaching the surface, and there would be no bloom. The seedlings make robust plants, and do not deteriorate materially.

The seed formation of the Crocus is very interesting. If dug a few weeks after its season of bloom 
is over, under the ground, below the blossom, the stem will be found to have expanded into a long chamber or cell as large around as a lead-pencil and an inch or more in length. Open this and it will be found full of exquisite pink pearls; these are the seeds. As they ripen they become nearly black, the cell bursts, and the earth receives them. The Scilla lengthens its flower-stems until they lie on the ground, forming large seed-pods filled with white pearls. When the plants are taken up, if these little seeds are saved the stock will increase much more rapidly.

The beds are often wanted for other plants before the foliage has had time to ripen. In that case the bulbs may le lifted and heeled-in, in some out-of-theway place, until ripe, care being taken to preserve the seed-pods. Heeling-in means digging a shallow trench, laying in the roots of the plants in a row, and covering them with earth. They must be lifted when ripe and not allowed to grow.

A pretty way to grow the Scilla, Crocus, and Snowdrop is to scatter them on the lawn in the grass, planting singly or in clumps. Lift the sod with the trowel and slip the bulbs under, right side up, leaving them to care for themselves. Plant hundreds in this way; they will be through blooming by the time the grass needs cutting.

The various varieties of Narcissi should be planted in permanent beds or borders, where they need not be 

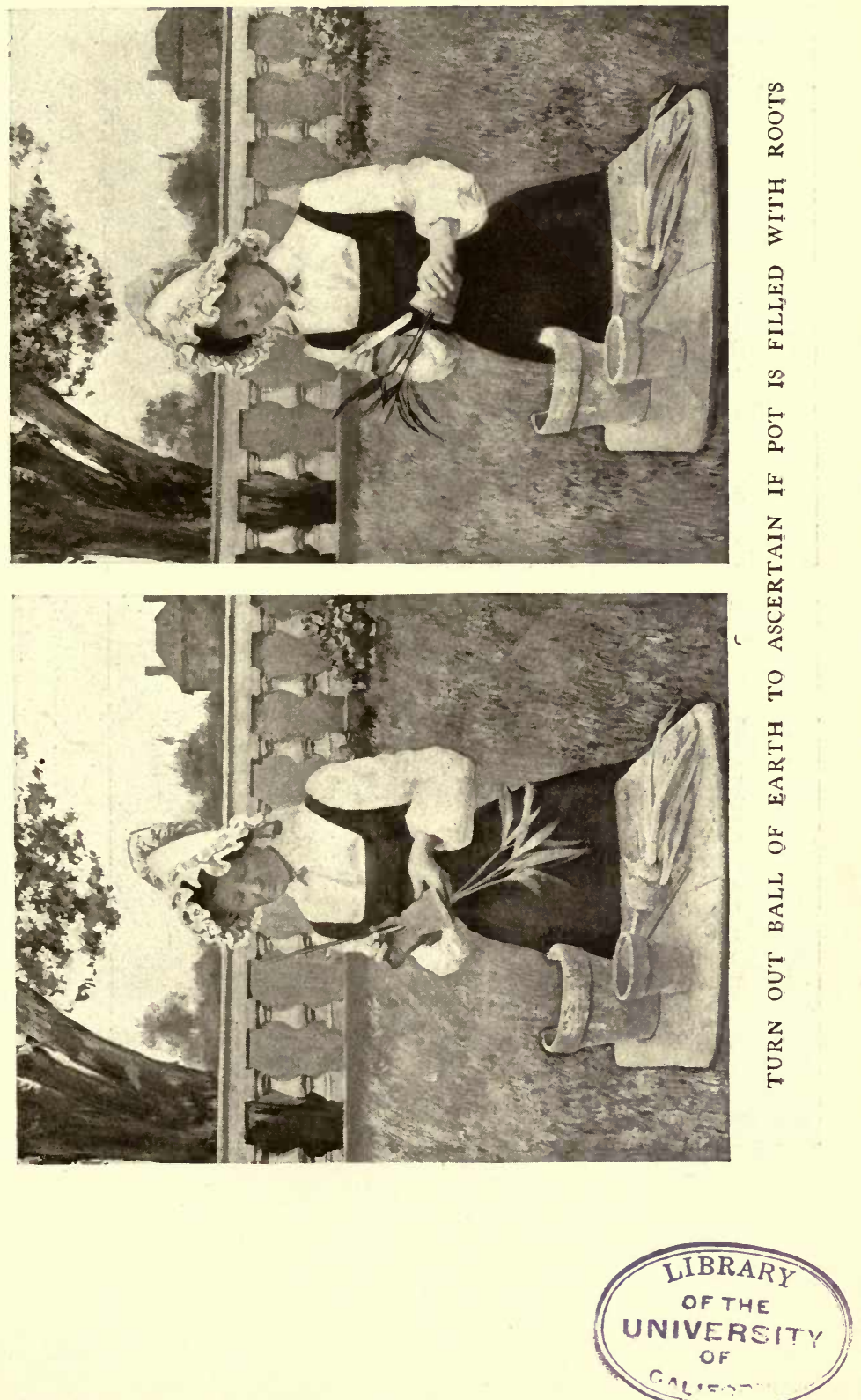

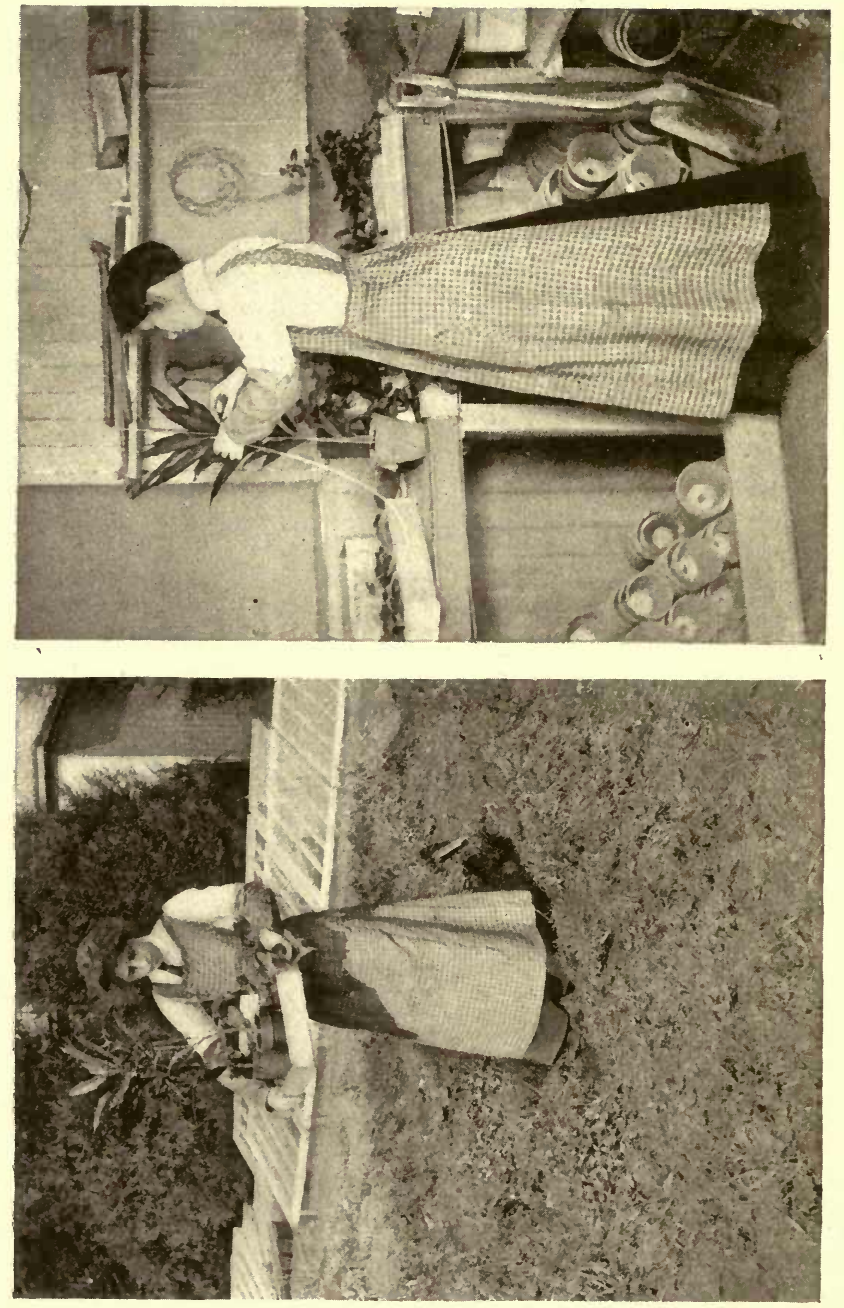

몽

c

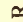

3

品

증

is

芯 
disturbed except as it is necessary to divide them. They should be set four inches deep and twelve inches apart each way, that they may have room to increase. The new bulbs of Narcissi form in a cluster around the old, and unless allowed to develop freely will not bloom. If set the proper distance apart they will need to be taken up but once in four years. Do not wait for them to show signs of a crowded condition, but move on schedule time, and keep them blooming continuously. All the Narcissi, except the Polyanthus, are hardy, and all are lovely-especially the large trumpet sorts. Emperor and Empress, Horsfieldi, and Sir Watkin are especially good in the open grounds. Poeticus, P. ornatus, Alba plena, Odorata, and Von Sion all make beautiful borders.

.There are a few other bulbs for fall planting that are hardy all over the country. The Chionodoxa, Glory of the Snow, is a recent introduction from Asia Minor. Like the Scilla it is blue, a rare and desirable colour in spring flowers. Winter Aconite, with its tiny, golden-yellow flowers, the first of the spring; Wood Hyacinths, Dog-tooth Violets, Fritillarias, Crown Imperials, and Snowdrops are all worth a place.

The bulbs advertised by the seedsmen as hardy in a temperature like that of Philadelphia may not prove hardy in Canada, Michigan, Northern Illinois, Minnesota, Wisconsin, Dakota, and this must be borne in mind when purchasing same. The safest way, when in 
doubt, is to address a letter of inquiry to the dealer offering the plants, in regard to suitability for your particular climate.

Bulbs for winter blooming. I have come to the conclusion that almost anything will grow and blossom if given the proper care. For the amateur, whose only field is the sitting-room window, it is better to undertake only those varieties with which one may be sure of success under ordinary care, as the Hyacinth, Narcissus, Scilla, Crocus, Anemone, Ornithogalum arabicum, and Freesia. These are absolutely sure bloomers, and much more reliable in the matter of producing flowers than a Geranium. In selecting Hyacinths the single will generally give better satisfaction than the double, and there should always be a generous proportion of white among the colours selected. Alba superbissima, Baroness Van Thuyl, and $\mathrm{La}$ Grandesse are among the best whites; Norma gigantea, Roi des Belges for pinks and reds; Ida is the best yellow; and Czar Peter and Grand Lilas the best blues.

Among the Narcissi nothing finer than the large trumpet varieties could be desired: Horsfieldi, with its yellow trumpet and snow-white perianth; Sir Watkin, or the Giant Welshman, as it is sometimes called; Empress and Emperor and the clustered Paper White are all exquisite; and the old double Von Sion is most effective in the window-garden.

Hyacinths and Narcissi require the same treatment: 
Pot as early in the fall as they can be obtained, using good compost and sufficient broken charcoal to insure good drainage; fill to within an inch of the top with the soil, using a four-inch pot for a single bulb or a six-inch one for three bulbs. Place the bulb with the tip slightly above the surface of the soil, label plainly with name and date of planting, and set away in a dark box in the cellar for six weeks or more, or until the pot is well filled with roots; this can be ascertained by turning the ball of earth out of the pot. If the earth is not well covered with roots return to the box for a few days longer. If there is sufficient root growth place in a warm, sunny window in a temperature of about $70^{\circ}$. When first potted they should be well watered, and thereafter kept merely moist, but on bringing to the light and heat they should have water in the saucer most of the time. When the flowers are fully expanded they may be moved into a cooler, less sunny window, where they will remain in perfection much longer.

Anemones give beautiful winter blossoms and require practically the same treatment as Hyacinths. The bulbs are placed an inch and a half below the surface. They are queer, shrivelled-up little things, with roots which fill up surprisingly after being in the damp soil. When up and growing they require abundant water and sunshine. Keep the saucer full of water all the time; failure in this respect means blasted buds. As Anemones give a succession of 
flowers they must be left in the window until through blooming. Tulips, Crocus, and Scillas should be potted and placed out of doors where they will not be disturbed, covered with earth and left until freezing weather, when they should be stored in the cellar like other bulbs. It is well in placing bulbs out of doors to set the pots in beds of coal-ashes to prevent the entrance of worms into the soil. They may be covered with ashes instead of earth, the object being to give them the benefit of the frost.

A half dozen Scillas planted in the centre of one of the large round gourds and surrounded with a border of white Crocus makes a very pretty show, and will come into bloom in about three months from the time of planting. The Ornithogalum is an effective flower, and quite sure to bloom, but requires a rather high temperature, as it is of slow development.

Freesia bulbs deteriorate very rapidly once they are out of the ground, and should be ordered early and potted as soon as received. Plant a dozen in a five- or six-inch pot, and set at once in a warm east window, as these do not need to go to the cellar. The leaves and stalks are very tender, and will require support, and this is the greatest objection to the Freesia. Ashes in the soil will counteract this tendency somewhat, and the wire carnation supports are very neat and satisfactory.

Alliums, which have the same defects, require the same treatment. 
The varieties of Oxalis are usually started in a sunny window, as they require a strong light. Like the summer bloomers, they increase rapidly and need considerable root room. The Bermuda Oxalis is lovely in a gourd hanging-basket; indeed, a hangingbasket, or bracket, is the only suitable arrangement for it, as it loves to droop and spread itself, and requires abundant room for its wealth of golden flowers. When through blooming it should be allowed to ripen its foliage. It may then be set in the cellar, or a cool place, until September, when the bulbs should be shaken out of the pot and repotted; one bulb to a four-inch pot.

Bulbs of hardy plants may be ripened off, and in the spring planted out in the open ground, where they will bloom the following spring, but are valueless for forcing in the house. 


\section{Chapter EIGHTEEN}

\section{亟aroy Shrubs and 羽lants for Jfall 羽lanting}

1

$\mathrm{N}$ some localities, especially in the South, the practice of setting out hardy plants in the fall has much to commend it. The mild winters, during which growth is never entirely checked, allow the plants to fully establish themselves; but in the Northern States, where the severe winters set in early and last long, the plants do not become sufficiently established to stand the severe cold followed by the hot summer. They sometimes live through the one only to succumb to the other.

Plants moved from one part of the grounds to another will frequently winter-kill, while those left undisturbed will be found in excellent condition in the spring. Again, a plant may come through the winter in apparently good condition, but without sufficient vitality to withstand any severe heat or drought, and failure to recognise this condition results in loss. Plants transplanted in the fall, however hardy their character, should receive particular care during the 


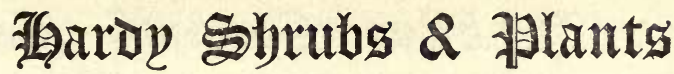

following summer in the matter of water, cultivation, and mulching. Plants transplanted at any time of year will do better if the top growth is reduced by trimming or cutting back, and all broken or injured roots removed with a sharp knife.

Spring-planted shrubs rarely fail to do well if the precaution is observed of moving them while dormant. The only exception I need to mention being the various Irises when purchased from florists. These, being dug in the fall, and kept in cold storage during winter, have their vitality much depleted by spring, and are then of doubtful value. This is especially true of the Japanese Iris; the German and English, being much more hardy, are not so easily injured. Home-grown Iris would better be moved in the spring.

Among the desirable shrubs for fall or spring planting are the various Spiræas; these are both shrubby and herbaceous. Of the shrubby variety Anthony Waterer is the only really good crimson, or red, variety, and is very fine. The catalogues give it a dwarf character rarely exceeding eighteen inches, but my own experience with the plant is, that with rich soil it much exceeds that height. Van Houttei is the finest white sort, and is especially valuable grown singly on the lawn, where it may develop its beautiful form to perfection. Of the herbaceous Spiræas the filipendula is very desirable for the border or for edging shrubbery. The fern-like foliage, which is of itself 
handsome enough to gain recognition, is surmounted in June with spikes of double daisy-like flowers of creamy white. It is very fine for cut flowers, and for forcing in winter. The clumps increase rapidly, and should be divided and reset every three or four years. Then there is the old-fashioned garden Spiræa, with its pinky-white, feathery blossoms, very fragrantespecially when wet with the dew.

Hypericum Moserianum is a delightful little perennial, growing from one to two feet tall; the flowers are exquisite in form and colour-a clear, golden yellow lasting well when cut. Other hardy yellow flowers are the California Sunflower and Rudbeckia, or Golden Glow, both too well known and popular to need eulogy.

The Lychnis (Rose Campion) is another of our herbaceous perennials which has not attracted the notice its good qualities deserve. L. Chalcedonica, its trusses of scarlet rivalling the most vivid Geranium, is the best known of the species, and combines beautifully with Clematis flammula and Spiræa filipendula. Planted against a wall covered with the Clematis, or contrasted in the border with S. Japonica, it is very effective. Plant L. semperflorens plenissima with Deutzia gracilis and Spiræa filipendula. Planted together in the border they are exquisite. L. semperflorens is much more delicate than the other Lychnis, and cannot be considered entirely hardy at the North. It is a very dainty little flower with soft pink, finely 


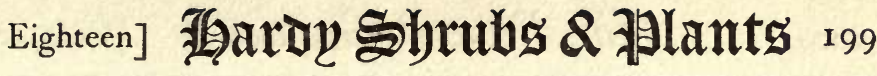

toothed blossoms, and worth considerable trouble to grow. Viscaria (Ragged Robin) has tall spikes of double red, deliciously scented flowers, and should find a place in every garden. Chalcedonica resembles the scarlet variety except in colour, which is pure white. It also is quite hardy and needs little care when once established.

Plant Iris (Fleur-de-lis) generously. They will grow in size and beauty from year to year, and are valuable for borders along drives or walks, for the filling of corners or low, damp spots. By planting the different varieties a succession of bloom, from May until the latter part of July, may be secured. The German Iris furnishes some magnificent colour effects in purple and bronze, yellow and lavender, blue and white. The Japanese are wonderful, both in colour and size-flowers seven inches in diameter being quite common, while twelve inches is attained in some instances. 'The flowers differ so materially in form from other Iris as to appear a distinct class. Unlike the German Iris, they hold their petals neither erect nor drooping, but horizontally, or flat, making a great disc of lovely colour, ranging through all the shades of blue, lilac, blue and white, and plum, to crimson-purple, magenta, and pink. They are more tender and less quickly started than the German, but do well when established. A low, damp spot suits them best, and where this is not available they should be abundantly supplied with water. German Iris will 
do well in any good garden soil and under ordinary cultivation. Iris should be taken up and divided every three or four years, removing all dead or exhausted growth, and setting one live toe, or point, in a place. They will not do well the first year of dividing, but the following year will be very fine, especially if there have been enough roots to make several long, parallel rows.

While not troubled with any disease or insect pest, the moles seem to have an especial liking for the roots of the Japanese Iris, and have caused me much loss. The only preventive is to shut the moles out of the bed by sinking a close wire netting around it to a depth of eighteen inches, or by making early and persistent use of good mole-traps-one at each end of the row, or at the spots where they enter and leave the bed. By this method I caught ten moles in as many days in the Iris beds, and was comparatively free from them the remainder of the season. Salt pork or bacon rinds buried in their runs will sometimes drive them away for a time, but this is not to be depended on, neither is the presence of Castor-oil plant, which, so far as I have observed, has not the slightest value. The only method is to trap them early in the spring, before they begin to breed; setting the trap in the runs from the nest and not in the shallow feeding runs they make close to the surface. These they may not visit again in days, if at all, but the main runs, which usually extend in several directions from their bur- 


\section{Eighteen] 酒arde}

rows, and are several inches below the surface, are traversed several times a day.

Peonies-what would the spring garden be without these old-time favourites? Whatever flowers are lacking in country gardens, it is rarely these; and yet, we seldom see them at their best. They like rich, well-drained soil in a sunny location, and once established should remain undisturbed for years, or until they become so crowded as to need dividing, as they require several years to recover after being moved, and only actual necessity should lead to their disturbance, certainly not the requests of friends and neighbours to dig them up and divide. Better buy a root to give away, if reluctant to refuse, than injure the plant.

Mulch the Peony bed heavily with rough manure in the fall, removing the coarsest in the spring and working the rest into the soil. A good mulch of lawn clippings during July and August will keep the soil cool and moist, and greatly benefit the plants. This should be given before they bloom, as there is usually heavy rain about that time, which beats the flowers down into the dirt and ruins them.

The Funkia (Plantain Lily), or Day Lily, as it is commonly called, is another plant impatient of disturbance; and once planted it should not be molested. It likes a good, rich, mellow soil, but is not particular as to location, so that no other plant is near it. Though perfectly hardy I prefer to give it a little 
protection in the winter. In the spring cut away the sod from around it the width of the spade, making the soil fine and mellow, and working in some old manure. This annual enlarging of its boundaries is all the care it needs to make it grow larger and finer, year by year, and bloom profusely.

The French Lilacs are to be recommended for liberal planting, as they are free from the vice of suckering which makes the old-fashioned sort so troublesome. They should be planted wherever they will be useful as backgrounds for lower shrubs, or perennials, or in a row along a lane or fence. As the blooming season of the different varieties varies, by judicious selection they may be had in bloom for several weeks.

Althæas (Rose of Sharon) have the happy notion of blooming when other plants do not, so they are doubly welcome. As they bloom from the bottom up they should have a place by themselves on the grounds, where they will make quite tall trees in a few years. The white and light-coloured ones are the most attractive. Young trees should be wrapped in straw during winter, and old ones well mulched with rough litter. 


\section{Chapter NINETEEN \\ Zminter 羽rotectín}

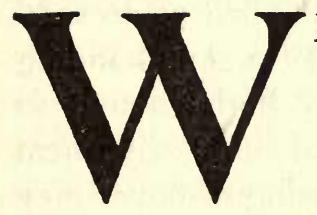

HEN the frost has cut down the flowers, and robbed the shrubs of their leaves it is time for the fall cleaning of the garden. This should be completed before the leaves begin to fall, as if left until then they will greatly complicate matters.

Pull up and consign to the compost heap all annuals, weeds, stalks of perennials, Lilies, and ornamental plants, and the litter used for mulch during summer. This last might be left on were it not for the fact that it is likely to harbour insects which would do mischief. It is therefore better to remove it and work the bed over, leaving all clean and neat.

This is the time to look out for cutworms, chrysalids, and the like, and destroy them. Much may be done in this direction. Look carefully along the edging between the curbing and the grass where the cutworm lurks. Look for the chrysalids of borers in the ground around the Clematis, Cosmos, Holly- 
hocks, and Dahlia beds, and when found destroy them. On the under side of boards, steps, and under the edge of the siding of the house will be found the cocoons of the hickory tussock-moth and the cabbageworm, all of which should be destroyed. After removing the dead annuals rake over the beds, leaving them clean and neat.

Beds of perennials, Roses, bulbs, and especially of Lilies and Peonies, must be well rounded up to shed water, as all plants are injured by water standing about their roots. If not already high enough to admit of this, more earth must be added to raise them sufficiently. The earth from the window-boxes may be used to advantage, especially for the Tea-rose bed, where a foot of mellow earth, brought well up around the plants and rounded to shed water, will so protect them that, though the tops may freeze, all below the soil will be likely to live. Over this should be placed several inches of rough litter or leaves and a frame of rough boards put around the beds and covered with sash, canvas, or boards to shed rain.

Young climbing Roses should have three or four inches of earth banked up around them; wrap their tops with straw or sacking, or old carpet may be drawn over them and tacked to the trellis or support on which they grow. Plants under the eaves of the house, where the water drips, should have boards arranged to catch and divert it to the lawn.

Protect equally from the cold winds of winter and 
the sun; plants are not injured so much by freezing as by thawing suddenly, as they must when the sun shines directly upon them. If they thaw gradually, little if any damage is done, but sudden thawing ruptures the plant-cells, causing serious injury. To prevent this and the settling of water about the roots are the points to keep in mind when giving winter protection.

For plants whose tops die, leaves offer an excellent protection-better than manure, in that they do not scatter seeds of weeds. For plants that form a fall crown of leaves-as the Hollyhock or Annunciation Lily - a box with an open end filled lightly with leaves is satisfactory. Close, air-tight covers, as boxes, tin pails, iron kettles, and the like, should never be used to protect plants of any kind. Wooden frames covered with wire netting and filled loosely with leaves, allowing the moisture to evaporate rapidly, have given the best results; next come frames covered with thin cotton cloth, then loose boxes with one end knocked out. The idea is to retain the dry leaves around the plant, protect from sun and cold wind, and allow the rapid evaporation of any moisture that may collect. Wet or frozen leaves around a plant are worse than no protection; especially is this true in the case of Myosotis, Pansies, Carnations, Canterburybells, and Foxglove, all of which do better in the coldframes. Where these are not available, recourse may be had to the boxes with netting, or to evergreen boughs. When filling in about a plant with leaves do 
it lightly, as a mass closely packed becomes damp and mouldy, and kills rather than protects.

Plants too tall to be covered should be protected with straw or corn-stalks; cover for some litttle distance beyond the roots with leaves or litter, and place straw or corn fodder around them, bringing it to a point at top, and tying firmly there and in the middle, sloping the stalks sufficiently to shed rain. Tall Rosebushes, young Althæas, and similar growths, are much benefited by this form of protection. Long beds of plants-as Japanese Iris, Pansies, and the like-may be protected by taking narrow boards eighteen or twenty inches long, with a notch cut in one end, the other end being pointed and driven into the ground; set these at intervals through the centre of the beds; place the poles lengthwise of the beds, their ends resting in the notches, and arrange evergreen boughs across the poles on each side to shed rain. Corn fodder may be used where the evergreens cannot be procured, or a row of pegs may support two boards, forming a $\Lambda$ shaped roof, which will protect from wind, sun, and water equally. Protect the Lily and Peony beds with a foot of leaves and rough, old manure. Rhododendrons, at the North, must have both roots and tops protected if there is to be any bloom the following year. Muslin-covered frames and leaves will do this best. Great care must be taken not to break off the buds, which are exceedingly brittle. Frames with removable lids that will admit of filling in gradually, 
and allow the leaves to settle before finishing, are best. Pile leaves around the roots of Clematis, and stretch sacking or other cloth over the trellises on which they grow. Protect in the same way English Ivy and Ampelopsis Veitchi while young. A northwest angle of a building affords very good protection. 


\section{Chapter TWENTY

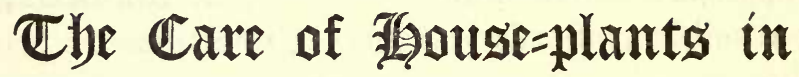 2 sinter}

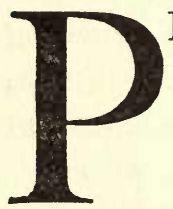

LANTS for winter blooming should be brought into the house before the nights get chilly. By becoming gradually accustomed to the air of the house before the doors are closed and the fires started, they will be less affected by the change.

Do not crowd into the window more plants than it can conveniently hold. Plants must have room to breathe and grow, and abundant light. No plant should touch its neighbours. Even with this amount of room at the start they will be badly crowded before spring, and it will probably be necessary to remove some.

Shelves, brackets, and stands should be in place before the plants are brought in, as changing about and handling are bad for them. Plants with tender foliage, as Cinerarias, Primulas, and the like, do best on a window-bracket, and the capacity of the window is greatly increased by the use of brackets. Plants with drooping leaves should have single brackets, to 


\section{政ouse=plants}

avoid contact with other plants. The Bougainvillea, also, does better on a bracket, being of a trailing habit. It is not, however, a good winter bloomer, usually coming in late in March and continuing until December, but it is very reliable during that time and requires less care than any house-plant with which I am familiar, unless it be the Araucaria.

See that all shelves are securely fastened, and strong enough to sustain the weight to be placed upon them. The additional protection of a small brass chain fastening the outer edge of the shelf to the windowcasing above it will ease the strain on the brackets and give greater security.

See that all hanging-baskets are securely hung with copper wire, and that there is no danger of the hooks from which they are suspended pulling out.

Do not start in with a number of plants the requirements of which are entirely unknown. Where conditions for their proper care are not obtainable it will be wiser to content one's self with familiar plants offering a reasonable hope of success, as Geraniums, Hyacinths, or Primroses. A healthy, vigorous plant, however common, is preferable to a sickly one, be it ever so rare.

A fair degree of atmospheric moisture should be maintained by keeping a dish of water on stove, register, or radiator. Where bulbs are grown a healthy degree of humidity is secured by evaporation and transpiration as shown by moisture gathering on 
the glass when the temperature falls. Moisture in the soil is a more difficult matter, and greater harm is done through ignorance in this particular than in any other way. Either plants are allowed to suffer for water, or they are drenched indiscriminately. All are watered alike, irrespective of individual need, whereas the requirements of each should be studied. A few plants, natives of bogs - as the Calla-require constant moisture when growing. Heliotrope, on the other hand, turns yellow when over-watered. Water should be applied thoroughly when given and then withheld until the plant is nearly dry again. This induces a stocky growth, with well-ripened wood, capable of producing healthy bloom. To keep a plant constantly wet may produce a quick growth, but it will be a soft one, incapable of the best results.

Flower-pots should not be filled to the brim with earth, but sufficient space should be left to hold enough water to thoroughly saturate the soil in each pot-a full inch or more in the case of six-inch pots, and at least half an inch for small pots. The soil must be sufficiently open to take the water quickly. Heliotrope, and some other plants, form a thick network of roots, which the water cannot penetrate readily, and channels should be opened through them with a pencil or stick. See that the water really penetrates the soil instead of merely passing between the ball of earth and the pot. Hanging- 
baskets of wire and moss are best watered by setting in a large pail until thoroughly soaked. One such watering will last a week, unless the room is very hot and diy.

Give sun-loving plants all the sunshine possible. Geraniums especially love to be close to the glass, and the difference is quickly seen in the quality of the blossoms. Shower every day, if possible, especially such plants as Heliotropes, Cinerarias, Cyclamen, Lantanas, and, if not once a day, at least once a week. Dipping the entire plant in a tub of quite warm water is a great benefit, as in that way every part of the plant is reached.

I do not especially approve of the advice so constantly given to "keep an old fork handy to stir the soil, that the roots may have air." The leaves are the lungs of the plants, and if these are kept clean there will be no trouble about their breathing. Moreover, if necessary to get air to the roots, stirring the soil would be a very poor way to do it, as cultivation of the surface is intended to keep air out and moisture in. To this end we make a dry mulch over flower-beds and the farmer cultivates his corn in a "dry spell," knowing that the formation of a dry crust will result in the rapid evaporation of the moisture in the soil, the dry air shrinking the soil and opening up its pores, as it were, letting the hot air in and the moisture out. This advantage the practice has: it counteracts any tendency to sourness in the 
soil, and should be resorted to whenever there is any suspicion of this, or when the earth in which tender or succulent-stemmed plants are growing seems hard and will not take water readily. The Amaryllis objects to this disturbance, and hardwooded plants, which require firm potting, should not be disturbed by more than the merest scratching of the surface.

Give support to such plants as need it, promptly; failure in this respect may result in the loss of a cherished blossom, or the disfigurement of a plant.

Pinch back all weak and straggling growths, trimming the plants to grow stocky and symmetrical.

Avoid, as far as possible, a sudden change of temperature, as a sudden chill will greatly injure some plants, though they may not be actually frozen. Plants may be left in the window as long as the glass is not frosted, but at the slightest appearance of frost they must be moved back out of actual contact with the glass. The thermometer drops suddenly at times, and plants that were considered quite safe at night may be found frozen in the morning. When the thermometer in the window indicates a safe temperature and that outside a stationary one, though very low, the plants may be left where they are; but beware of falling temperature, and protect with several thicknesses of newspaper between the plants and the window, bringing it well out beyond the window-frames. All cracks between the sash and casing should be carefully 
sealed with strips of cloth or paper, the colour of the woodwork, neatly pasted over, effectually shutting out draughts. This alone will help immensely in protecting plants, and storm-windows are safe and save much trouble.

Fresh air, which plants must have, should be supplied through another room, where it will be warmed before reaching them. A screen, so placed as to cut off draughts when a door is opened to air the room, will be found a great convenience.

When plants are frozen they should be thawed very gradually. Darken the room and keep the temperature low, raising it gradually. If, however, the plants are in a living-room, where the temperature cannot conveniently be kept low for any length of time, remove them to the cellar until the frost is drawn out of them, when, if not too badly damaged, they may be returned to the window and encouraged to grow. Geraniums are rarely injured by one freezing, the loss of the leaves being the chief damage, and if the plants are returned at once to the window this may prove an advantage, as wherever a leaf falls a new shoot will usually be forced, making the plant much more stocky and thrifty. During an unusually severe storm, a Geranium left in the window of a room away from direct heat was badly frosted. As it was not a very choice variety no effort was made to save it. The room was closed, and a temperature of $12^{\circ}$ below zero reigned for several days. When the weather 
moderated and the temperature rose to $32^{\circ}$ the room was opened and warmed, the Geranium remaining on its shelf. In a few days, seemingly, the axil of every vanished leaf had bourgeoned into tender green, and in a short time the Geranium was as thrifty as ever, blossoming better the following summer than at any time before. Favourable growing conditions should be given as soon after freezing as possible, that all the vitality may be utilised and not wasted to sustain life in the unfavourable conditions existing in cellars.

Showering with, and dipping in, cold water slightly above freezing are also good for frosted plants; $33^{\circ}$ is about right, as a higher temperature will be apt to precipitate the evil it is desired to avoid-the rupture of the plant-cells.

The freezing of the soil in pots, which often happens with bulbs or plants kept quite wet, does no particular harm, and no attention need be paid to it as long as the tops are not frozen.

Remember that heat rises, and that the upper sash of a window is many degrees warmer than the lower, so that by having an upper shelf you can grow plants requiring a much higher temperature than those on the lower shelf. For the same reason hanging-baskets require much more water than plants on low shelves. and should be showered frequently to counteract the dryer atmosphere. A rubber sprinkler is indispensable for this purpose; by its use flowers may be suf- 
ficiently showered every day to keep back red spiders and materially change the atmosphere.

Compost, sand, old manure, and drainage material should be prepared in the fall and put in a frost-proof place ready for any repotting that may be necessary during the winter, and for the early sowing of seeds in the house.

In another chapter will be found formulas for the various insecticides required for the extermination of the pests likely to attack plants in the close, dry air of the living-room. If attention is paid to the supply of fresh air and moisture little, if any, trouble will be experienced on this score.

Plants coming into bloom will require some fertiliser, and as there are objections to the use of manurewater in the house the following formula will be found very satisfactory: Get at the druggist's one and a half pounds (or ounces) nitrate of soda, onehalf pound (or ounce) phosphate of soda, and one pound (or ounce) sulphate of potash. Mix and pulverise the material thoroughly. When required for use put a rounding tablespoonful of this mixture in a gallon of hot water. To fertilise the plants put a teacupful of the water, when cool, on a six-inch pot, and more in proportion on larger pots. Do not use oftener than once in two weeks, and do not let it touch the foliage.

All the Asparagus group are benefited by the use of a good fertiliser, especially is this the case with $\mathrm{A}$. 
Sprengeri, which makes a root growth so vigorous that it would be unmanageable were it not for the use of fertilisers, which make it possible to keep it within reasonable bounds.

Begonias, on the other hand, are usually injured by the use of fertilisers. 


\section{Chapter TWENTY-ONE}

\section{Common and Englisib Pames of Jflowers}

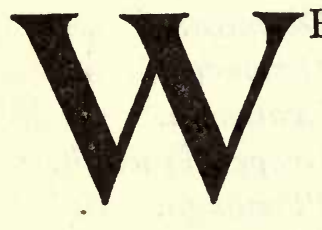

Abyssinian Banana, Adam's Needle, Alleghany Vine, Alum Root, American Cowslip, American Senna, Amethyst, Artillery Plant, Aurora's Bower, Australian Glory Pea, Baby's Breath, Bachelor's Button, Balsam Apple, Balsam Pear,

See Musa.

"Yucca.

"Adlumia.

"Heuchera.

"Dodecatheon.

"Cassia.

"Browallia.

" Pilea.

"Gaillardia.

"Clianthus.

"Gypsophila.

"Globe Amaranth.

" Momordica.

" Momordica. 
Banana Shrub,

Barrenwort,

Basket of Gold,

Bath Flower,

Beard Tongue,

Bird's Nest Fern,

Bishop's Weed, Black-eyed Susan,

Bleeding Heart,

Blood Flower,

Bluebottle,

Bluebottle,

Blue Leadwort,

Blue Lyme Grass,

Blue Salvia,

Blue Vetch,

Bluet,

Boston Ivy,

Bowman's Root,

Bugle,

Bugle Vine,

Burning Bush,

Butterfly Flower,

Butterfly Flower,

Butterfly Orchid,

Butterfly Weed,

Calico Bush,

California Poppy,
See Magnolia.

" Epimedium.

" Alyssum.

" Trillium.

"Pentstemon.

"Aspidium NidusAvis.

" Egopodium.

" Thunbergia.

“ Dicentra.

"Homanthus.

"Centaurea.

" Grape Hyacinth.

" Plumbago.

"Elymus.

"S.patens.

"Grape Hyacinth.

"Houstonia.

"Ampelopsis.

"Gillenia.

"Ajuga.

"Calampelis.

"Euonymus.

"Centrosema.

"Schizanthus.

" Epidendrum.

"Asclepias.

"Kalmia.

“ Eschscholtzia. 


\section{Twenty-one] \$2ames of $\mathfrak{J l o w e r s}$}

Canterbury Bell,

Cape Hyacinth,

Cardinal Flower,

Castor Bean,

Cheneil Plant,

Chilian Glory Flower,

Chimney Bell Flower,

Chinese Bell Flower,

Chinese Lantern Plant,

Chinese Matrimony

Vine,

Chinese Paper Plant,

Christmas Berry,

Christmas Rose,

Cinnamon Vine,

Cinquefoil,

Climbing Fumitory,

Climbing Hawthorn,

Cock's Comb,

Columbine,

Cone Flower,

Coral Plant,

Corn Flower,

Cowslip,

Crane's Bill,

Creeping Mallow,

Crown Vetch,

Cruel Plant,

Cup-and-Saucer Plant,
See Cámpanula.

"H. candicans.

"Lobelia.

"Ricinus.

"Acalypha.

“ Eccremocarpus.

"Campanula.

"Platycodon.

"Physalis.

" Lucium.

"Bougainvillea.

"Ardisia.

"Helleborus.

“ Dioscorea.

"Potentilla.

"Adlumia.

" Actinidia.

"Celosia.

"Aquilegia.

“ Rudbeckia.

“ Erythrina.

"Centaurea.

“Primula.

" Geranium.

" Callirhoe.

"Coronilla.

"Physianthus.

"Campanula. 
Cup-and-Saucer Vine,

Cup Flower,

Cushion Pink,

Dark Mullen,

Day Lily,

Devil-in-the-Bush,

Double Buttercup,

Dropwort,

Duck Plant,

Dutchman's Breeches,

Dutchman's Pipe,

Dusty Miller,

Dusty Miller,

Edelweiss,

Emerald Feather,

English Daisy,

Evening Glory,

Evening Primrose,

Everlasting,

Everlasting,

Everlasting,

Everlasting,

Everlasting,

Everlasting,

Everlasting,

Fair Maids of France,

False Chamomile,

False Dragon Head,

False Indigo,
See Cobara.

" Nierembergia.

"Armeria.

"Verbascum.

"Hemerocallis.

"Nigella.

"Ranunculus.

"Spircaa.

"Aristolochia.

“ Dielytra.

"Aristolochia.

"Centaurea.

" Cineraria.

"Gnaphalium.

"Asparagus.

"Bellis.

"Ipomoea.

"Enothera.

"Acroclinium.

"Ammobium.

"Globe Amaranth.

"Helichrysum.

" Lathyrus.

" Rhodanthe.

"Xeranthemum.

"Ranunculus.

"Boltonia.

"Physostegia.

"Baptisia. 
Feverfew,

Fire on the Mountain,

Flame Flower,

Fleur de Lis,

Flora's Paint Brush,

Florida Rattle Box,

Floss Flower,

Flowering Currant,

Flowering Dogwood,

Flowering Maple,

Flowering Sage,

Flowering Spurge,

Forget-me-not,

Fountain Plant,

Four-o'clock,

Fringe Flower,

Garden Flower,

Gardener's Garter,

Garland Flower,

Gas Plant,

Gay Feather,

Gilliflower,

Globe Flower,

Glory Pea of Australia,

Goat's Beard,

Gold Lack,

Golden Bush Pea,

Golden Feather,

Golden Honey Bell,
See Matricaria.

"Euphorbia.

" Tritoma.

" Iris.

"Cacalia.

"Crotolaria.

"Ageratum.

" Ribes.

"Cornus.

"Abutilon.

"Salvia.

" Euphorbia.

"Myosotis.

"Acalypha.

" Marvel of Peru.

"Schizanthus.

"Schizanthus.

" Phalaris.

"Daphne.

"Dictamnus.

" Liatris.

"Cheiranthus.

"Trollius.

"Clianthus.

"Spirca.

"Wall Flower.

"Crotolaria.

“Pyrethrum.

"Mahernia. 
Golden-leaved Elder,

Golden Rod,

Golden Tuft,

Great Reed,

Great Sea Lavender,

Groundsel,

Hawk's Beard,

Holly Fern,

Honey Bell,

Horn of Plenty,

Horned Poppy,

Horse Mint,

House Leek,

Humble Plant,

Hyacinth Clematis,

Jacobean Lily,

Jacob's Ladder,

Japan Quince,

Japanese Bell Flower,

Japanese Beni,

Japanese Hop,

Japanese Ivy,

Japanese Primrose,

Japanese Primrose,

Japanese Virgin's Bower,

Japanese Winter Cherry,

Jerusalem Cherry,

Jerusalem Cross,

Kenilworth Ivy,
See Sambucus.

"Solidago.

"Alyssum.

“Arundo Donax.

" Limonium.

" Glechoma.

"Crepis.

"Crytomium.

" Mahernia.

" Datura.

"Glaucium.

" Monarda.

"Sempervivum.

" Mimosa.

"Clematis Davidiana.

"Amaryllis.

"Polemonium.

"Pyrus.

"Platycodon.

"Caryopteris.

"Humulus.

"Ampelopsis.

"Cortusoidea.

"Primula.

"Clematis.

"Physalis.

"Solanum.

" Lychnis.

" Linaria. 


\section{Twenty-one] \$2ames of $J$ floluers}

Lady Washington,

Larkspur,

Lavender Cotton,

Lawn Pearlwort,

Lemon Verbena,

Leopard Plant,

Lilac,

Lily of the Palace,

Lily of the Palace,

Little Bo-Peep,

Liverwort,

London Tufts,

Look at $\mathrm{Me}$,

Love Grove,

Love in a Mist,

Love Lies Bleeding,

Lungwort,

Madagascar Periwinkle,

Maidenhair Fern,

Mallow,

Maltese Cross,

Mariposa Lily,

Marsh Mallow,

Meadow Beauty,

Meadow Sage,

Meadow Star,

Mexican Fire Plant,

Mexican Lily,

Michaelmas Daisies,
See Pelargonium.

“ Delphinium.

"Santolina.

"Spergula.

"Verbena.

"Farfugium.

" Syringa.

"Agapanthus.

"Amaryllis.

"Antirrhinum.

"Hepatica.

“Srweet William.

"Centrosema.

"Nemophila.

"Nigella.

"Amaranthus.

"Martensia.

"Vinca.

"Adiantum.

" Hibiscus.

"Lychnis.

"Calochortus.

"Hibiscus.

"Rhexia.

"Salvia.

"Spircea.

"Euphorbia.

"Amaryllis.

"Aster. 
Monkey Flower,

Monkshood,

Moon Flower,

Moonpenny Daisy,

Moonwort,

Morning Glory,

Mosses,

Moss Pink,

Moss Verbena,

Mother of Thousands,

Mountain Fleece,

Mountain Fringe,

Mountain Laurel,

Mourning Bride,

Mouse-ear Chickweed,

Moustache Plant,

Musk Plant,

Old Maid,

Old Man,

Old Woman,

Orchid Vine,

Oriental Poppy,

Oswego Tea,

Painted Daisy,

Painted Leaf,

Painted Tongue,

Pampas Grass,

Pancratium,

Paris Daisy,
See Mimulus.

"Aconitum.

"Ipomoea.

"Chrysanthemum.

"Honesty.

"Ipomeea.

"Selaginellas.

"Phlox.

"Verbena.

"Saxifrage.

"Polygonum.

"Adlumia.

"Kalmia.

"Scabiosa.

"Cerastium.

"Caryopteris.

" Mimulus.

"Vinca.

" Artemesia.

"Artemesia.

" Stigmaphyllon.

"Papaver.

" Monarda.

"Chrysanthemum.

" Euphorbia.

“ Salpiglossis.

"Gynerium.

"Ismene (in part).

"Chrysanthemum. 
Passion Flower,

Peacock Flower,

Pearl Bush,

Peppermint,

Periwinkle,

Persian Daisy,

Pheasant's Eye,

Pincushion Flower,

Pinks,

Plantain Lily,

Plume Poppy,

Pot of Gold,

Purple Bells,

Purple Fountain,

Purple Grass,

Purple-leaved Plum,

Queen Lily,

Ragged Robin,

Ragged Sailor,

Red-hot Poker,

Rock Cress,

Rock Madwort,

Rose Campion,

Rose of Heaven,

Rubber Plant,

Sage Palm,

St. John's Wort,

St. Bernard's Lily,

Sand Root,
See Passiflora.

"Tigridia.

" Exochorda.

"Mentha.

"Vinca.

"Pyrethrum.

"Adonis.

"Scabiosa.

"Dianthus.

"Funkia.

"Bocconia.

"Calendula.

"Rodochiton.

"Pennisetum.

"Pennisetum.

"Prunus.

"Amaryllis.

"Lychnis.

"Centaurea.

"Tritoma.

"Arabis.

"Alyssum.

"Lychnis.

"Agrostemma.

"Ficus.

"Cycas.

"Hypericum.

" Liliago.

"Arenaria. 
Sand Verbena,

Scarbrough Lily,

Scarlet Flax,

Scarlet-fruited Gourd,

Scarlet Sage,

Sea Holly,

Sea Pink,

Seal Flower,

Segar Plant,

Sensitive Plant,

Shaking Fern,

Shell Flower,

Shooting Star,

Shrubby Honeysuckle,

Silk Oak,

Silver Bells,

Slipper Flower,

Smoke Tree,

Snapdragon,

Sneezewort,

Snowball,

Snowberry,

Snow in Summer,

Snow on the Mountain,

Southern Wood,

Speedwell,

Spider Plant,

Spike Grass,
See Verbena.

"Vallota.

" Linum.

" Bryonopsis, or

Gourds.

"Salvia.

"Armeria.

"Armeria.

“ Dielytra.

"Cuphea.

“ Mimosa.

"Pteris.

“ Tigridia.

“ Dodecatheon.

“ Lonicera.

" Grevillea.

"Halesia.

"Calceolaria.

"Rhus.

"Antirrhinum.

"Helenium.

"Viburnum.

"Symphoricarpus.

"Cerastium.

“ Euphorbia.

"Abrotanum.

"Veronica.

"Cleome.

"Uniola. 
Spring Beauty,

Starworts,

Stone Crop,

Straw Flower,

Sulphur Fern,

Sunflower,

Sun Plant,

Swan River Daisy,

Swan River Everlasting,

Sweet Olive,

Sweet Sultan,

Tassel Flower,

Thrift,

Toad Flax,

Toad Lily,

Tobacco Plant,

Torch Lily,

Tree Celandine,

Trumpet Flower,

Trumpet Vine,

Umbrella Plant,

Variegated Comfrey,

Venus' Looking-Glass,

Virgin's Bower,

Wake Robin,

Wawhaw,

Wax Plant,

Wax Plant,
See Claytonia.

"Asters.

"Sedum.

"Helichrysum.

“Gymnogramma.

"Helianthus.

" Portulaca.

"Brachycome.

" Rhodanthe.

" Olea.

"Centaurea.

"Cacalia.

"Armeria.

"Linaria.

"Castalia.

“ Nicotiana.

"Tritoma.

“Bocconia.

" Datura.

“ Bignonia.

" Cyperus.

"Symphytum.

"Campanula.

"Clematis.

" Trillium.

"Euonymus.

"Hoya.

"Mesembryanthemum. 
White Fringe,

Whitlow Grass,

Wild Cucumber,

Wind Flower,

Winged Everlasting,

Wolf's-bane,

Wood Lily,

Woodruff,

Yellow Flax,

Youth and Old Age,

Zanzibar Balsam,

Zebra Grass,
See Chionanthus.

"Draba.

"Echinocystis.

"Anemone.

"Ammobium.

"Aconitum.

" Trillium.

"Asperula.

" Linum.

"Zinnia.

" Impatiens.

" Eulalia.

TIME FOR GERMINATION OF SEEDS

From Three to Five Days

Ageratum,

Ammobium,

Aster,

Celosia,

Centaurea,

Chrysanthemums,

Cypress Vine,

Gilla,

Hollyhock,

Lavatera,

Layia Elegans,

Leptosyne Maritima,

Marigold,

Mimulus,
Mina lobata,

Salvia,

Sedum,

Silene Shasta,

Spherogyne,

Stevia,

Stock-ten week,

Sweet William,

Tradescantia,

Trifolium,

Tunica,

Verbascum,

Veronica,

Virginian Stock, 
Viscaria,

Vittadenia,
Whitlavia,

Zinnia.

\section{In Five to Seven Days}

Acacia,

Amaranthus,

Arabis Alpina,

Beta,

Brompton Stock,

Bromus,

Browallia,

Candytuft,

Cannabis,

Carnations,

Centaurea,

Chelone,

Chrysanthemum Indicum,

Cineraria,

Clitoria,

Coleus,

Coreopsis Lanceolata,

Crucianella,

Cuphea,

Cynoglossum,

Dahlia,

Daisy,

Eschscholtzia,

Eupatorium,
Gaillardia,

Geranium,

Gypsophila,

Hablitzia,

Helenium,

Helianthus,

Helichrysum,

Hibiscus,

Iberis Gibraltarica,

Linaria Reticulata,

Lobelia,

Lupinus,

Lychnis,

Malva Moschata,

Mathiola,

Mesembryanthemum,

Mignonette,

Morning Glory,

Nicotiana,

Picotee,

Pink,

Salpiglossis,

Schizanthus. 


\section{In Eight to Ten Days}

Abutilon, Achimines, Agrostemma, Antirrhinum, Armeria, Balsams, Begonia,

Calceolaria,

Campanula, Annual,

Canna,

Capsicum,

Commelyna Cœelestis,

Deutzia,

Digitalis,

Dracocephalum,

Erianthus,

Gaura,

Gloxinia,

Gnaphalium,

Hibiscus Syriacus,
Humulus Japonica,

Kaulfussia,

Lychnis,

Morina,

Pansy,

Pansy, Viola,

Papaver,

Pentstemon,

Petunia,

Phacelia,

Phlox Drummondi,

Poinsettia,

Potentilla,

Pyrethrum,

Rudbeckia,

Thunbergia,

Tropæolum,

Valeriana,

Verbena,

Zea.

\section{In Ten to Twelve Days}

Achillea,

Alonsoa,

Alyssum Saxatile,

Anchusa,

Aquilegia,
Argemone,

Artemisia, Asphodelus, Aubrietia, Bidens, 


\section{Twenty-one] $\$$ Zames of $\mathfrak{J l o w e r s}$}

Calandrinia,

Calonyction,

Campanula,

Feverfew,

Galtonia,

Geum,

Gypsophila,

In Twelve to Fifteen Days

Anemone Sylvestris, Antigonon, Asters, Per.,

Callirhoe,

Campanula Tenorei,

Datura,

Didiscus,

Gazanopsis,

Gourds,

Hunnemannia,

Lantana,

Mandevillea,

Maurandya,
Helianthemum,

Linaria,

Ipomopsis,

Scutellaria,

Silphium,

Spiræa.
Ranunculus,
Myosotis,

Nicotiana,

Nierembergia,

Peas,

Perilla,

Petunia, Double,

Platycodon,

Polemonium,

Ricinus,

Thalictrum,

Torenia,

Verbena Venosa.

\section{In Fifteen to Twenty Days}

Acanthus,

Agapanthus,

Anemone,

Antigonon,

Armeria Maritima,

Calla,
Cobæa,

Cuphea,

Dictamnus,

Geranium Sanguineum,

Heliotrope,

Hemerocallis, 
Impatiens Sultana,

Iris,

Liatris Spicata,

Primula Sinensis,
Rivina Humilis,

Smilax, Boston,

Solanum Robustum,

\section{In Twenty to Thirty-five Days}

Adlumia,

Baptisia Australis,

Berberis Vulgaris,

Campanula Fragilis,

Campanula Leutweiana,

Campanula Macrantha,

Campanula Nobilis,

Clematis Diversifolia,

Clematis Integrifolia,

Clianthus Dampieri,

Delphinium Nudicaule,
Funkia,

Gentiana Acaulis,

Hibiscus Speciosa,

Humea Elegans,

Musa Ensete,

Phlox, Perennial,

Phormium,

Physianthus,

Tritoma Uvaria,

Yucca.

\section{One Year or More}

Adlumia,

Ampelopsis,

Anthericum,

Clematis, in variety,

Dictamnus,

Fuchsia,
Iris,

Lilies,

Lupinus Polyphyllus,

Musa,

Tradescantia,

Viola Odorata.

Geranium Sanguineum,

In the foregoing tables it will be observed that a flower occasionally appears in two or more sections. 
When this occurs, the first date indicates the time in which strong and fresh seed should germinate in flats in the house, or in hotbeds; the latter indicates the time for old seed, under less favourable conditions, and marks the limit of time in which plants may be expected. 


\section{Chapter TWENTY-TWO}

\section{Blooming Seagon of Sartous Crees, brubs, and 羽lants}

T.-Tree. S.-Shrub. V.-Vine. H. P.-Hardy Perennial. A.-Annual. H. H. P.-Hardy Herbaceous Perennial. E.-Evergreen.

\section{April}

Akebia Quinata.................. P. V. Alyssum Argenteum................. P.

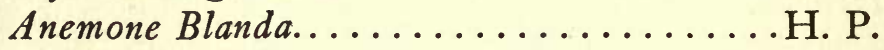
Bellis Perennis.................. P. E. Dicentra-Bleeding Heart........... H. H. P. Dicentra-Dutchman's Breeches........... P. P.

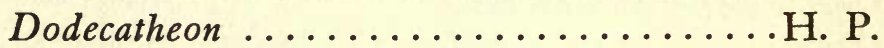
Forsythia-Golden Bells................ S. Sanguinaria-Blood Root.............. H. P. Saxifrage...................... P. Uvularia-Bellwort ................. P. Vinca, Periwinkle, Myrtle............ P. E. Violets, in var................. P. E. 


\section{3łlooming Saasong}

\section{May}

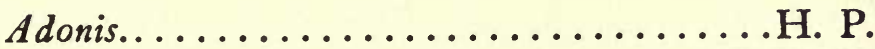
Ajuga........................ H. P. Alyssum Argenteum................. H. P. Alyssum Saxatile.................... H. P. Amsonia...................... H. P. Aquilegia Argenteum.............. H. P. Arum-Cuckoo Flower............. H. H. P. Aubretia....................... H. P.

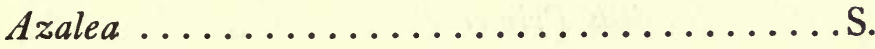

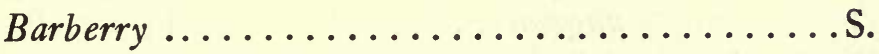
Bellis_English Daisy............. . P. E. Callicarpa Japonica. . . . . . . . . . . . . H. P. Calycanthus-Sweet Shrub............ P. S. Chionanthus-White Wings........... P. P. Convallaria-Lily of the Valley......... H. P. Daphne........................ S. E.

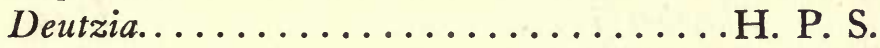
Dicentra.................... H. P. Doronicum . . . .................. H. P. Double-flowered Almond................ S.

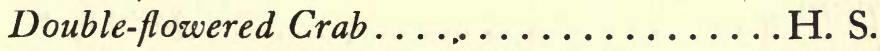
Double-flowered Peach................... S. Epimedium.................. H. P. Euonymus-Burning Bush.............. S. Exochorda-Pearl Bush................. S. Genista.......................... P. Halesia-Snowdrop................ T. 
Hawthorn ..................... T. Honeysuckle-Bush.................. S. Iris Aurea...................... H. P. Iris Siberica................. H. P. Lychnis_Red Campion............... H. P. Ornithogalum-Bulbous.............. H. H. P. Phlox Subulata........................ P. Polemonium-Greek Valerian.............. P. Polyanthus....................... P. E. Potentilla, June to August.............. P. Primula-English Primrose............ P. E. Pulmonaria-Lungwort............. H. P. Pyrus_(Cydonia) Japonica............ P. S. Ranunculus........................ $\mathrm{H}$. P. Rhododendrons.................... E. Ribes_Flowering Currant.............. S. Sanguinaria-Blood Root............... H. P. Spircea Filipendula.................. H. P. Spirca Thunbergi.................... S. Spircea Van Houttei................... S. Syringa-Lilac..................... T. Tamarix........................... S. Trillium..................... H. P. Veronica......................... P. Viburnum-Snowball................. S. Vinca-Myrtle................... P. E.

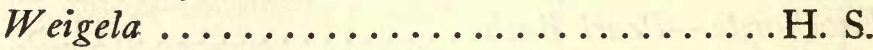




\section{June}

Aconitum-Monkshood................ H. . P. Alstromeria-Peruvian Lily............ H. H. P. Anchusa..................... H. P. Anthemis.................... H. P. Anthericum-St. Bruno's Lily. .......... H. H. P. Aquilegia...................... H. P.

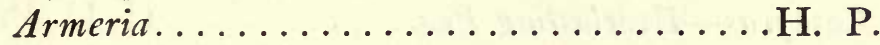

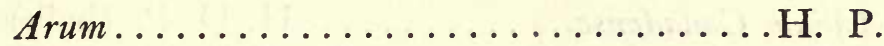
Astragalus-Milk Vetch............. H. H.

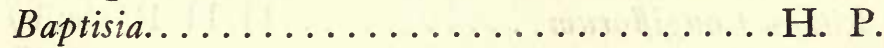
Bellis...................... P. E.

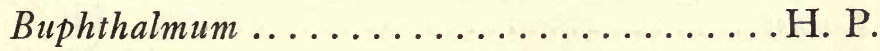

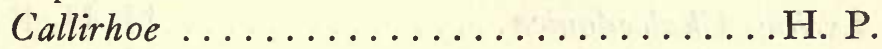
Campanula..................... P. E. Cassia.......................... P. Catalpa...................... T. Centaurea ........................ P. Centranthus........................ P. Coreopsis...................... P. Cornus_Dogwood................ T. Coronilla......................... P. Delphinium................. H. P.

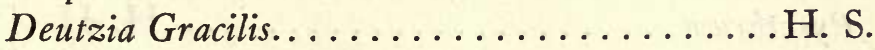
Deutzia_Pride of Rochester............... S. Digitalis................... P. E. Doronicum...................... P. Dracocephalum................... P. 
Erigeron.

.H. P. Heuchera. .................. H. H. P. Hollyhock. ................H. H. P. E.

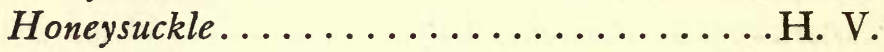
Hydrangea-Climbing............. P. V. Iris..................... H. P. Jasminum................... H. P. Laburnum...................... T. Lathyrus-Everlasting Pea............ H. H. P. Lilium Canadense............. H. H. P. (bulb) Lilium Candidum........... H. H. P. E. (bulb) Lilium Longiflorum . . . . . . . . . H. H. P. (bulb)

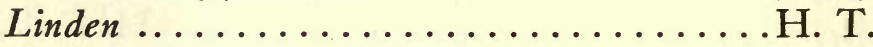
Locust ........................ T. Lychnis Chalcedonica............ H. H. P. Lychnis Coronaria................ H. P. Lychnis Gigantea............... H. P. Magnolia.................. T.

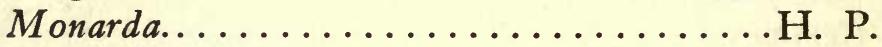
Mountain Ash.................... T. Papaver-Poppy.............. H. H. P. \& A. Pentstemon....................... Philadelphus.................. T.

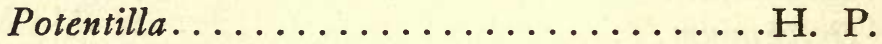
Pyrethrum.................. H. T.

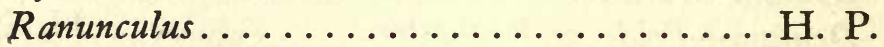
Rhododendron.................... E.

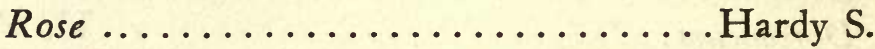

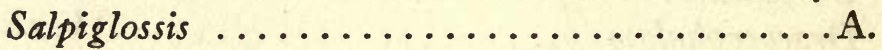




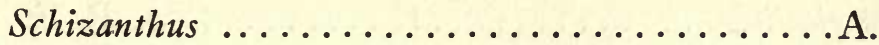
Sedum ......................... P.

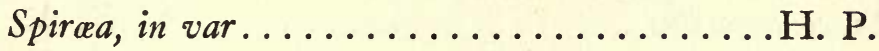

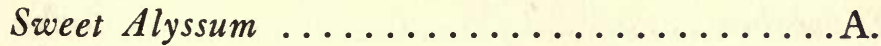

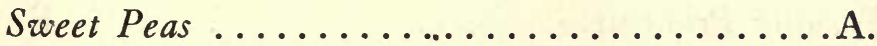
Sweet Scabiosa...................... P.

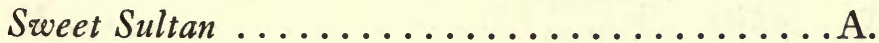
Veronica................... P.

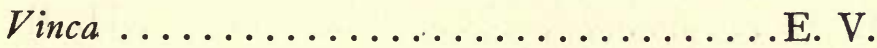
Violets..................... P. E.

\section{July}

Achillea................... H. P. Allium Angularis ................... P.

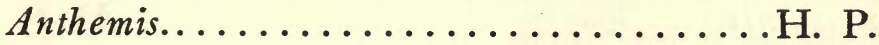

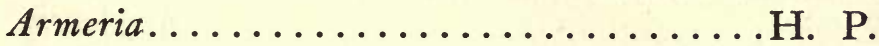

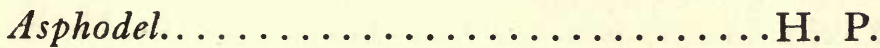
Aster Alpinus.................. P. Bignonia Radicans................ P. V.

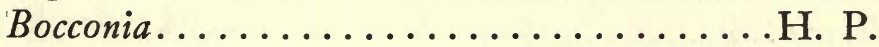
Campanula...................... P. E.

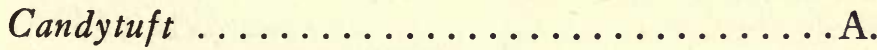
Chrysanthemum Maximum............. P. Cobcea Scandens..............Tender P. V.

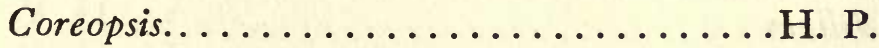

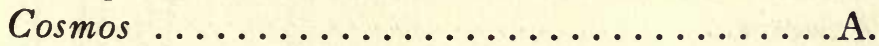
Dahlia .................... Tender P.

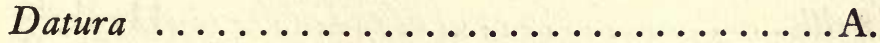
Dictamnus.................... P. 
Digitalis

.H. P. E.

Dracocephalum.................... P. Eccremocarpus .................... V. A.

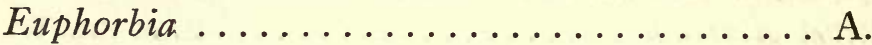
Evening Primrose................... P. Funkia ..........................

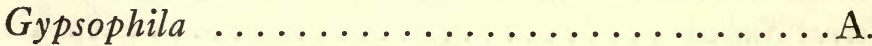
Iris_-Japanese ................... P. Liatris .......................... P. Lilium Auratum.................... P. Linum......................... P. Lychnis...................... H. P. Perennial Phlox................... H. P.

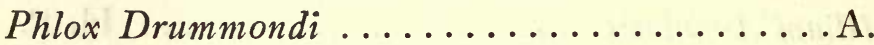
Potentilla ......................... P. Salvia .......................Tender P. Statice ......................... P. Thalictrum ...................... P. Thymus ........................ P.

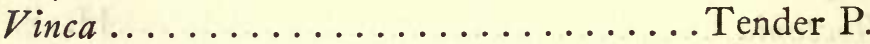
Yucca....................... P. E.

\section{August}

Achillea....................... H. P. Allium ......................... P. Armeria....................... H. P. Asphodel....................... H. P. Bellis......................... P. E. Callirhoe ....................... P. 
Campanula.................. P. E. Carnation .................... P.

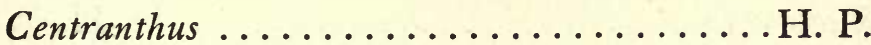
Clerodendron ....................... P.

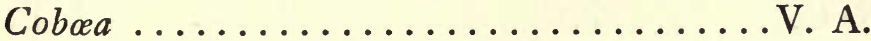

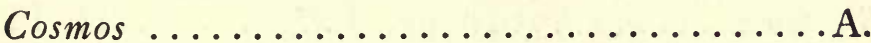
Delphinium .................... P. Dianthus.................... H. P. Digitalis..................... P. E. Dolichos .......................... . A. Eupatorium .................... P.

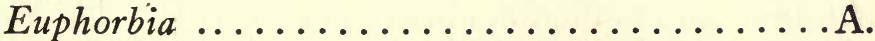
Funkia.................... H. P. Helianthus ..................... P. Hibiscus..................... H. P.

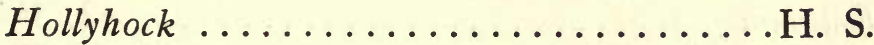
Hydrangea, late in August........... P. S. Hypericum Moserianum................. S. Liatris ......................... P. Lilium Album................. H. P. Lilium Auratum.................. H. H. P. Lilium Melpomene. ............... H. P. Lilium Roseum.................... H. P. Lilium Rubrum................... H. P. Lobelia Cardinalis................. H. H. P. E. Lychnis..................... H. P.

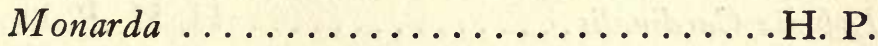

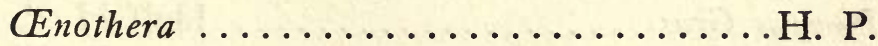
Pentstemon ...................... P.

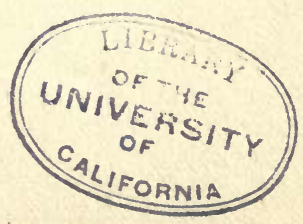


Phlox, Perennial................... H. P. Platycodon....................... H. H. P. Rudbeckia..................... H. P. Salvia ..................... Tender P. Sedum ......................... P. Silphium ...................... P. Statice ........................ P. Vinca $\ldots \ldots \ldots \ldots \ldots \ldots$................ Tender P.

\section{September}

Althea....................... P. T. Anchusa ....................... P. Anemone-Queen Charlotte...........H. H. P. Anemone-Whirlwind................ H. P. Asters, in var................ \& H. H. P. Boltonia ....................... P. Clematis Paniculata................ P. V. Erianthus ....................... P. Eulalia ........................ P. Eupatorium ..................... H. P.

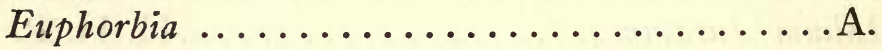
Gladiolus....................... Bulbs Golden Rod..................... H. P. Hibiscus.................. H. P. \& T. P. Hydrangea ..................... P.

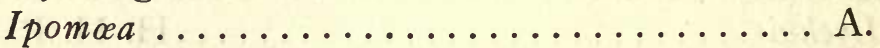
Lobelia Cardinalis................ H. P. E. Pampas Grass....................... Half H. P. Rudbeckia ...................... P. 
Salvia ................... P. Statice ....................... P. Tritoma .................... Tender P. Vinca ..................... Tender P.

\section{All Summer}

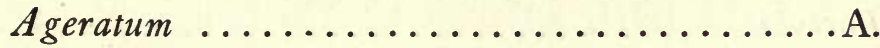
Antirrhinum ................... P.

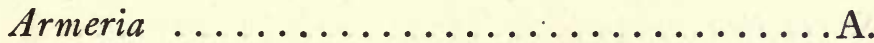

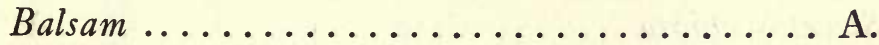

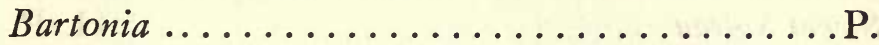
Begonia, Tuberous................. P. Begonia, Vernon................ P.

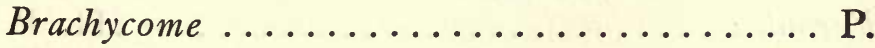

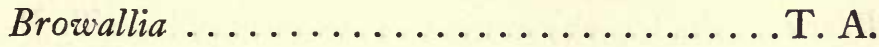

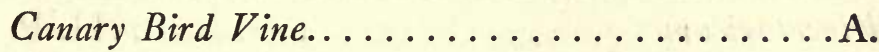

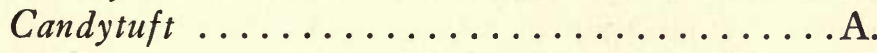
Canna............... Tender P. Rhizomes

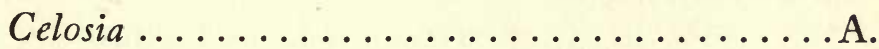

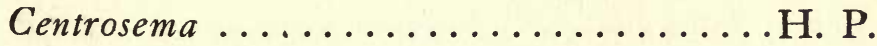

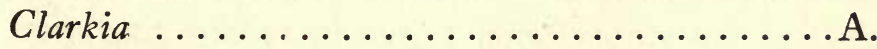

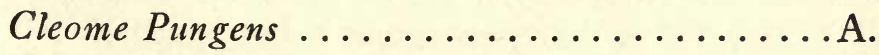

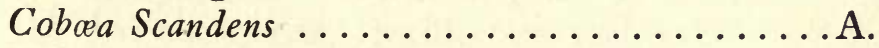

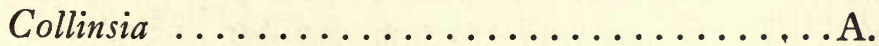

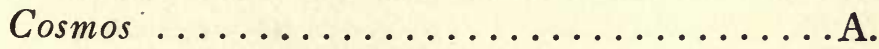

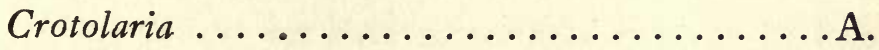

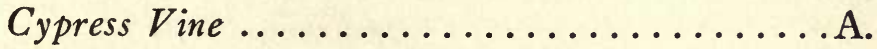
Delphinium .................... P. Gloxinia ................... P. 
Hyacinthus Candicans.................. P.

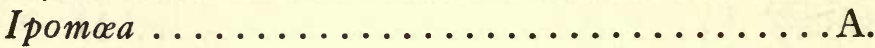

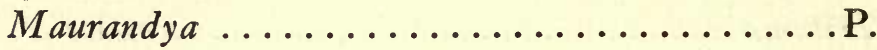

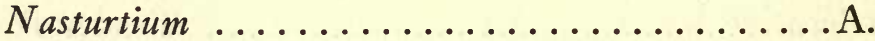

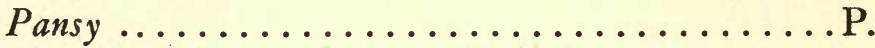

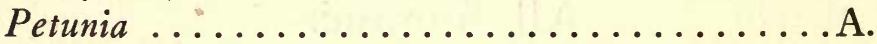

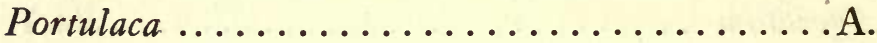
Rose..............Hardy or Half Hardy S.

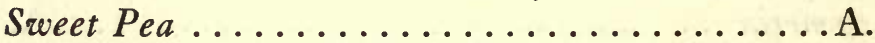

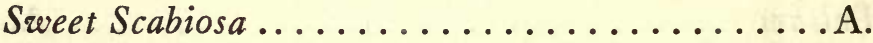
Sweet Sultan ...................... P. Thunbergia ..................... P. P. Verbena ...................... P. Veronica ...................... P. Vinca ....................... P. Vincetoxicum .................... P. 


\section{Chapter TWENTY-THREE \\ $\mathfrak{A}$ Chapter of $\mathbb{O D d s}$ and $\mathbb{E} \mathfrak{E}$ ds}

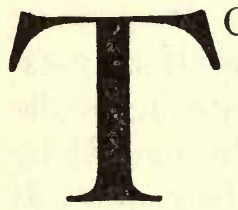

OOLS: There is always a tendency among beginners to overload with the paraphernalia of their calling, whatever it may be. When the first enthusiasm passes, and one becomes a careful and successful worker, all that is superfluous is gradually dropped, and one realises that it is brains and not tools that make the successful gardener. A hotbed, a cold-frame or two, a work-table in some convenient place, a trowel, wheel-barrow, spade, pitchfork, rake, hoe, a few yards of stout cord, a hatchet to sharpen stakes, a watering-pot, rubber sprinkler, rubber gloves, a good supply of pots and wire-netting, and a couple of good mole-traps cover the real necessaries. Incidentals, such as wire-sieves, lath-screens, trellises, and the like, may be made as they are required.

One should not have more tools than can be kept in good working order.

An excellent place for Begonias, Gloxinias, and other shade-loving plants is made by fitting a wide 
shelf under a north or east window on the outside, with a raised edge three or four inches high, made by tacking strips of wood across the front and ends. Inclose with window-netting, first nailing strips of wood from the outer corners of the shelf to the upper corners of the window-casing to support the netting. When the shelf is filled with wet sand, and the plants plunged in it, one has a miniature greenhouse accessible from the room, and safe from trespass of chickens, cats, or careless feet. The shelf may extend considerably beyond the window-casing if desired, and be made attractive from the outside by climbing vines. The Maurandya is fine here, as it will push its tips through the netting, and be very ornamental; the Asparagus tenuissimus and A. plumosus nanus are also good. A couple of plant-brackets fastened to the outside casing will afford room for drooping plants, and add to the attractiveness of the shelf. Primroses will bloom here all summer, and Ferns, Gloxinias, and fancy-leaved Caladiums find a congenial home.

\section{Insecticides}

A GOOD supply of insecticides should be kept in A store, or at least the formulas and materials for preparing them. Plant enemies have increased to such an alarming extent in the past few years that comparatively few flowers are free from them, and 
some kinds, as the Rose, Dahlia, Aster, Clematis, and Cosmos, are becoming more and more difficult to raise. The Rose, especially, is in need of constant care and watchfulness from the swelling of the leaf-bud until the end of the growing season. One of its most dreaded fungous diseases is known as "black spot," which must be given thorough treatment in the beginning, before the leaves start in the spring on plants that have been previously affected. Syringe with Bordeaux mixture and repeat once or twice a week during the growing season.

Cosmos Borer is very destructive to the Cosmos, Dahlia, Asters, and Clematis; the preventive is a teaspoonful of Paris green to three gallons of water, poured around the base of the plant, using sufficient to wet the ground three or four inches deep. Begin when the plant is a foot high, and continue until fully grown.

The Black Beetle is an unpleasant pest that has become very destructive to the Asters, eating the flowers, and soon destroying an entire bed if not promptly checked. It resembles the common blister beetle, but is smaller and jet black in colour; it is easily killed by knocking off into a pan of water containing a little kerosene. In the early morning it is very sluggish, and may be picked off and killed, or the plants may be showered with the Paris-green solution, but the appearance of the first bug must be the signal for active operations. 
Plant Louse or Green Fly: This little insect commonly infests house-plants; it is called a fly because in one stage of its existence it has wings. The remedies are tobaccó in some form, or sulpho-tobacco soap syringed on the foliage, or the hot-water bath.

Black or Chrysanthemum Lice require practically the same treatment. Tobacco-dust on the leaves will usually prevent their appearance, and should be applied early in the summer and after every rain.

The Mealy Bug is a little whitish mass, like cotton in appearance, often found on house-plants and on the Spiræas. Syringe with whale-oil soap solution; or, if the plant is small, work over it, touching each bug with a brush dipped in alcohol; or use the hot-water bath.

Red Spider can only be kept at bay by fresh air and the plentiful use of water; spray or syringe daily. Use the hot-water bath if the spiders have gotten a foothold.

Rose Hopper, or Thrips-small yellowish insects on the under side of Rose leaves, from which they suck the juice, causing them to turn brown; whaleoil soap syringed on the under side of the leaves is the best remedy.

Rose Slugs are small green caterpillars that feed on the Rose leaves and buds, lying on the under side of the leaves, or drawing two leaves together with a slight web. Work over the plants, pinching the leaves between thumb and finger, or syringe with whale-oil solution, or dust with powdered hellebore when wet. 
Rose Bug - a small, dark bug striped with light yellow, which is very destructive to the Roses, eating the flowers. Plants may be syringed, or showered with the Paris-green solution at night or early in the morning, but must be attended to promptly, as the bugs are very destructive, stripping a bed of its flowers in a surprisingly short time. Roses treated with Paris green should always be plainly and conspicuously labelled to that effect.

Earth-worms and the like may be easily destroyed by thoroughly soaking the soil in the pots with limewater, which is best done by plunging a pot to the brim (not over) in the solution, and removing the worms as they come to the surface. It may be necessary to repeat this once or twice.

\section{Formulas}

The following formulas are from the New York Agricultural Station and are reliable:

Normal, or 1.6 per cent. Bordeaux Mixture Copper Sulphate (blue vitriol) ......6 6 pounds Quicklime (good stone lime).......4 pounds Water ................... 50 gallons

Dissolve the copper sulphate by putting it in a bag of coarse cloth, and hanging it in a wooden or earthen vessel containing five or six gallons of water. After the copper sulphate has dissolved, dilute with water to twenty-five gallons; slake the lime, and add twenty- 
five gallons of water; mix the two, and keep thoroughly stirred while using. If the mixture is to be used on Carnations, or the like, it will adhere better if a pound of hard soap be dissolved in hot water and added.

\section{Kerosene Emulsion}

Hard Soap ................ $\frac{1}{2}$ pound Boiling Water ................ I gallon Kerosene ................. 2 gallons

Dissolve the soap in the water; add the kerosene, and churn with a spray or force-pump until they unite and have the appearance and consistency of buttermilk. Dilute with water to twenty-five or thirty gallons before applying.

\section{Paris-green Solution}

Paris green ................. I pound Water ................... 50 gallons

Keep constantly stirred when using.

\section{Hot-water Bath}

The hot-water bath will, in nearly every case, take the place of insecticides and give better results, as it thoroughly cleanses the foliage and leaves no bad effects, if not too hot. Heat to $140^{\circ}$ if for spraying, and use before it cools; $136^{\circ}$ if the plants are to be dipped. 
Next in convenience to a pair of rubber gloves for the garden are the duck mittens sold for household purposes. All sorts of garden work may be done in these, even the transplanting of quite small plants. They have also the advantage of being very cheap, or they may be manufactured at home. Always have an extra pair on hand. Gardening without gloves is ruinous to the hands and a needless discomfort.

For watering the window-garden, a small pot with a long spout that will go between the plants will be a great convenience, as by its use the farthest plants may be watered without disturbing the others. This means a saving of time on busy mornings, and insures against neglect.

The life of the gardener who raises chickens is full of perplexities. Certainly nothing is more vexing and discouraging than to have one's plants repeatedly scratched out of the ground by chickens. With netting so cheap there is no good reason why chickens, or other farm stock, should have the range of the yard.

Nothing is more filthy or conducive to disease than the presence of fowls in the door-yard. There are few house-yards that cannot be isolated from the rest of the premises by a judicious use of wire-netting, and where the conditions call for it this should be the first thing done. It will not be at all satisfactory to surround the beds with netting, which is inconvenient and unsightly. The whole yard, or at least the entire garden, should be inclosed, using netting 
high enough to turn any fowl, say at least five feet; even Plymouth Rocks will take a four-foot fence. For Brown Leghorns six feet is a safer height than five feet. There should be no place on the top of the fence on which the birds can alight. At the bottom a board will make all secure, and prevent the chickens digging under; and it will be better if set a little below the surface of the ground, which should be made hard and firm around it.

Fences may be made attractive with vines or plants. Sweet-peas, Nasturtiums, Morning-glories, Cobæa scandens, Wild Cucumbers, the Scarlet-fruited Gourd, Roses, Clematis or Honeysuckles make a good background for the lawn and beds of bright flowers. 


\section{Chapter TWENTY-FOUR}

\section{A Chapter of 迎on'ts}

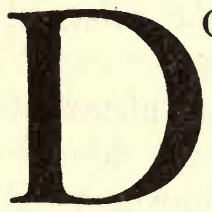

ON'T forget to air the hotbeds on warm, sunny days, and to protect them on cold ones.

Don't forget that plants need room to develop, and set them far enough apart to make this possible.

Don't forget to water the window-boxes every day, and to keep the sand in the sand-box wet all the time.

Don't forget to go over the Pansies and Sweetpeas every day, and remove all withered flowers. Don't let them suffer for want of water at any period of their bloom.

Don't try to raise more plants than you have room for, or strength and time to cultivate. A few plants well cared for are better than a neglected gardena most discouraging sight. The gardener will find enough real difficulty without inviting disaster.

Don't try to follow all the advice that is offered you; make up your mind what you want to do and go steadily ahead. If you fail you will know how, 
and why, which is in itself a distinct gain. It is a good rule never to take the advice of an unsuccessful person, no matter how reasonable it sounds. Distrust garrulous advice; the gardener with real knowledge is not inclined to force advice upon others.

Don't be cast down by adverse criticism unless your judgment tells you it is deserved. The person who "knows it all" is never so much at home as in some one else's flower-garden, where the principal labour may be done with the tongue.

Don't be wheedled into spoiling your plants by saving seed for one who is perfectly able to buy; instead, give the address of the dealer from whom you purchased, and suggest that he will be glad to fill orders. Don't rob your plant of cuttings that are necessary to its symmetry; this, too, is a case for the florist. There are people who seem to feel it an injustice for any one to possess a plant with more than one branch so long as they are not supplied with that particular variety.

Don't, when you have purchased a dozen Violets or Primulas, meaning to divide them after awhile to make the border you did not feel like purchasing outright, be imposed upon to the extent of giving half of them away to some one who has been waiting for this very opportunity. The experienced gardener learns to steer such people away from plants she does not wish to part with, or have mutilated, but the amateur is looked upon as legitimate prey. I have 
frequently known people to break a branch from plants they were handling, with the expectation of being told to keep it. The remedy for this sort of thing is to immediately place it in the ground with some remark about having a place for it.

Don't supply with cut flowers, plants, and the like, people who spend more money for unnecessary luxuries than you do for your whole garden, and then tell you how foolish you are to spend so much time and money, and work so hard for your flowers. Don't be too deeply impressed with the sudden friendship at gardening time of the woman who has managed to get along without your society all winter. Don't be imposed upon by the chronic plant-beggar, but suggest to her that you will be glad to lend your catalogues; that in them she will find, at reasonable prices, all the things you have in your garden; and that the florist will doubtless be glad of her patronage.

Don't, on the other hand, be lacking in generosity of the right sort. Flowers may be given to rich and poor alike, and carry no hint of obligation, or unfitness. To the tired worker who has neither time nor space to cultivate them, a handful of flowers, or a potted plant, which can be spared from your abundance, will make a bit of sunshine well worth the trouble. For many who cannot spare the trifling amount a single plant or packet of seed would cost, the surplus plants from flats or hotbeds will be a great pleasure, and one should not wait for re- 
quests. Those who really cannot afford these things are rarely guilty of the petty meanness of the professional plant-beggars. It is a good plan to jot down, from time to time as they occur, the names of those you would like to benefit in this way, and then, when you have surplus plants, send word of that fact, and of the time when it will be convenient to take them up. This will be better than sending the plants, which might arrive when it would be inconvenient or impossible to attend to them.

There are so many ways of giving pleasure with flowers that one need never be embarrassed with a surplus: the sick; the young girl who will enjoy them for her party; the young matron, for her prettty luncheon; the church service, the humble funeral, where the choicest and best should go. A beautiful tact may be shown by a choice in harmony with the taste of the recipient and the occasion for which they are intended. Do not send all white flowers, or flowers with a heavy perfume, to the sick-room. Bright flowers are better. Notice the cheer in a pot of golden Daffodils or a bunch of Hepaticas. A charming thing is a handful of Japanese Morningglory buds picked and sent the night before, that the invalid may watch their unfolding in the morning. I have known these to give the greatest pleasure.

Don't be too greatly cast down by failures; they have their uses. One failure, if it sets you to studying out the cause and remedy, is worth a dozen hap- 
hazard successes. We grow plants with even success for some time, then, without any recognised change in the treatment, we meet with failure. We look for the reason, and our education is begun. When we have found the cause of failure, we have made a long step forward.

Don't fail to take some good floral magazines, they are helpful in many ways, and keep you in touch with what other workers are doing.

Don't try to work in unsuitable clothing. Easy, broad, solid shoes-not any old run-down pairshould be considered as essential as a spade, or rake, and skirts that clear the instep, and hang comfortably. Waists with easy arm-holes and collar will enable one to work with a degree of comfort that means the accomplishment of an amount of work in a morning quite impossible were one less comfortably clad. Skirts of blue denim, made Princess style, and ankle length, with comfortable shirt-waists - denim for cool days, calico for warm-make a thoroughly comfortable outfit. 


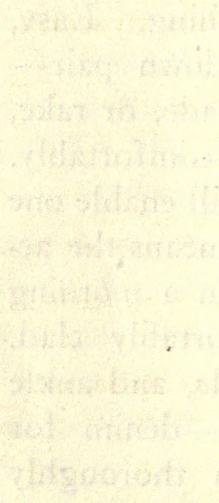




\section{Alphabetical IJndex}

A

Abobra viridiflora, fancy gourd, 96.

Abutilons, $63,64,92$.

Diversity of form and colour of New California, 64.

Time for flowering, 63 .

Achimenes, 60 .

Cuttings of, how to root, 60 .

Aconite, Winter, I9I.

Adverse criticism, hints about, 254.

Advice, hints about, 253.

Adlumia (Mountain Fringe, Climbing Fumitory, Allegheny Vine), 46, 92, 129.

Appropriate for use at funerals, 129.

Delightful grown on north side of house, 129.

Gathering seed from, 46 .

Sowing seeds and planting, 129.

Ageratum, Cope's Favourite, I I 9 .

Tom Thumb, 16.

Ageratums, 16, 34, 35, 46, 81, $88,91,92,94,96$, I01, I I9, I2I.

Dwarf variety admirably adapted for carpet bedding, II9.

How to sow, 35 .

Indispensable for edgings, window-boxes and vases, Ior.

Little Dorrit and Swanley Blue, 102.

Princess Caroline, 102.

Season for sowing, 102.

Should be clipped frequently, 47 .
Ageratums-Continued.

Tom Thumb, useful for edgings, IOI.

Air=tight covers, should never be used to protect plants, 205.

Alba plena Narcissi, I9I.

Alba superbissima Hyacinth, 192.

Allegheny Vine, I29.

Allemannia Cannas, I5.

Alliums, care and treatment of, I94.

Altheas, 201, 202, 206.

Alyssum. See Sweet Alyssum.

Amaryllis, 75, 155, 162-165.

Evergreen, 162.

General treatment of, same as for Crinums, I62.

Johnsonii, 163.

American Beauty Rose, I 78 .

Ammonia, a stimulant for flowers, 25.

Ampelopsis, 128, 207.

Anchusa capensis. II9.

Anemones, 192, 193.

Treatment and raising of, 193.

Annuals, various, from seed, 98I II.

Hardy and tender, time for planting, 53 .

Should not be grown in windowboxes, 96 .

Annunciation Lily, 205.

Anthony Waterer, crimson Spiræa, 197.

Antirrhinums (Snapdragons), $46,91,93,96,98,99$.

Firefly, 98. 
Antirrhinums-Continued.

Giant Crimson, Giant Yellow, Giant White and Niobe, 98.

How to protect in winter, 99 .

Queen of the North, 98.

Seed of, 46 .

Soil suitable for, 99 .

Transplanting, 98 .

Useful for cut Howers, windowboxes and vases, 98 .

When to start seed, 98 .

Ants, nests of, in the Lily bulb, remedy for, 181 .

Aphides, or green plant-lice, prevention and remedy for, 70 .

April, shrubs and plants that bloom in, 234.

Aquatic Plants, $165-172$.

Aquilegia. See Columbine.

Arrangement of flower-beds, Io.

Arundo Donax, ornamental grass, $5,16$.

Ashes, a good fertiliser to sweeten the soil, 25.

Should not be mixed with manure, 25.

Asparagus, 49, 64, 88, 94, 246.

All kinds benefited by frequent repotting, 64,65 .

Benefited by use of good fertiliser, 215 .

How to raise and manage, 65 .

Asparagus plumosus nanus, 246.

Proper time for planting, 64 .

Asparagus Sprengeri, how to sow, 49, 50.

Successfully grown in baskets or pots, 65 .

Unmanageable without fertiliser, 216.

Asparagus tenuissimus, 246.

Asters, 10, 25, 34, 43, 53, 99.

A necessity of the fall garden, 99 .

Aim of the specialist, 99.

Arranging for vases, roo.
Asters-Continued.

Bees do not care for, 43 .

Black beetle an unpleasant pest to, 247.

Bride, 99.

Chrysanthemum flowered, 99, Ioo.

Cosmos borer destructive to, 247 .

Early planting recommended, Ioo.

Frequent watering necessary, IOI.

Giant White Comet, 99.

Japanese Tassel, 97.

Kerosene for killing insects on, IOO.

Ostrich Feather, 99.

Paris-green in the watering-pot for killing beetles, 100.

Peony, 99.

Perfection, 99.

Proper place for planting, $\mathbf{\text { Io. }}$

Transplanting, IOI.

Use of seed of, 43 .

When to plant seed, 100 .

Aster-beds, ashes for fertilising, 25.

Atmospheric moisture, maintaining a fair degree of, 209.

August, shrubs and plants that bloom in, 240-242.

Auratum Lily, growth of the, on wooded hillsides, I84.

Aurea Bambusa, I7I.

Aurora Pansy, ir6.

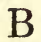

Bacon rind, for keeping moles from Iris roots, 200.

Balsams, 47, 102, 103.

Benefited by transplanting, IO2.

Camellia-flowered varieties best, 102.

Double white and shell pink, valuable for decorative work, 103. 
Balsams-Continued.

Plenty of room required for branching, 102.

Starting the seed, 102.

Transplanting, I02.

Bamboo, I7 I.

Requires abundant water-supply, I 7 I.

Varieties of, I71.

Bambusa Arundinacea, I 7 I.

Aurea, I 7 I.

Metake, I7I.

Banana plants, 145 .

Caring for, in winter, 145 .

Grow more ornamental indoors, 145.

Planted in tubs or open ground, 145.

Plants should be grown by themselves, 145 .

Showy and attractive, 145.

Soil and water for, 145 .

Southeast angle of building an ideal location for, 145 .

Storing in cellar during winter, 146.

Baroness Van Thuyl Hyacinth, 192.

Baskets, hanging. See Hanging-Baskets.

Beetles, black. See Black beetles.

Begonia cuttings, how to root, 60.

Begonia, Dwarf Bijou, 66.

Erfordii, 66.

Rex, how to plant and raise, 66 .

Vernon, 66.

Vulcan, when to plant, 66.

Begonias, 39, 48, 58, 60, 66, 67, $88,92-94,97$, II $7,150,245$. An excellent place for, $245,246$. Injured by use of fertilisers, 216.

Setting out, and storing during winter, 67,68 .

The best varieties of, 66 .
Begonias-Continued.

The finest flower for bedding or pot culture, 67 .

Begonias, tuberous-

Bedding out, 150 .

Instructions for planting, bedding and setting out, 67 .

Proper temperature for growing, I5o.

Shading from the heat, $15 \mathrm{I}$.

Starting and potting, I5O.

Bermuda Oxalis, should, be grown in hanging-baskets, 195 .

Bignonia Radicans (Trumpet Vine)-

Best method of supporting it, 140.

Blooms nearly all summer, 139 .

Desirable as a climber, 140.

Grown as a lawn shrub, I40.

Hedges of, should be kept pruned for symmetrical growth, I39.

Most desirable for hedges, I 39.

Not appreciated sufficiently, 139.

Black Beauty Cannas, 15 .

Black beetles, a pest to Asters, 247.

How to destroy, Ioo.

Black lice, remedy for, 248.

"Black spot," fungous disease of the Rose, 247.

Black=eyed Susan, I 36 .

Blood, from slaughter-houses, a good fertiliser, 28.

Blooming season of various trees, shrubs, and plants, 234-244.

Boards for siding in making flower-beds, 8.

Bone-meal, a substitute for, 27 .

As a fertiliser, 28.

Bonfire Salvia, I2I.

Bordeaux mixture, for fungoic disease in Pansies, 115. 
Bordeaux mixture-Continued. As an insecticide, 244.

Formula for, 249.

Borders, exquisite flowers for, I97, 198.

Borers, destroying chrysalis of, 203.

Bougainvillea, 209.

Bouquet, an ideal, ro3.

Bracket plants, Thunbergias valuable for, in winter, 136 .

Brackets, use of, increases capacity of window, 208, 209.

Bride Aster, 99.

Bride Rose, I 78 .

Bruant Geranium, for south and west window-boxes, 9I.

Bryonopsis, 96, 132.

Bulbous and tuberous = rooted plants, 147 .

Bulbs, for the amateur, I92.

For winter blooming, I92.

Hardy in Middle States, may not be so in Northern States, I9I, 192 .

Hints on potting outdoors, 194. Late fall or winter planting of, preferable to spring planting, I 88.

Of hardy plants, caring and preserving, 195.

Burbank Cannas, 15 .

Burpee's Defiance Petunia, 84 .

Buying seeds, 41-47.

\section{C}

Cabbage-worm, how to destroy, 204.

Caladium esculentum (Elephant's Ears), 149.

An ideal plant for the amateur, I49.

Native of Sandwich Islands, I49.

Root of, edible, 149.
Caladium esculentum - Continued.

Roots should be started in pots, I49.

Winter easily and multiply rapidly, 150.

Caladiums, $5,15,18,22,88,89$, 93, I49, I50, I $51,185,186$, 246.

Beds of, 5 .

Proper soil for, 18 .

Caladiums, fancy-leaved-

Caring for, in fall and winter, 151 .

Desirable for window-boxes and for porches, $15 \mathrm{I}$.

Develop their colours best in the shade, $15 \mathrm{I}$.

Flourish in a warm atmosphere, $15 \mathrm{I}$.

Gorgeousness of colour and delicacy of growth, $15 \mathrm{I}$.

Calceolaria, 63, 68, 74 .

Handling and raising, instructions for, 68.

Infinite variety of, 68 .

One of the most easily cultivated house-plants, 68 .

Varieties and easy cultivation of, 68.

California Sunflower, 197.

Callus, formation of, in cuttings, 61 .

Camphor Geraniums, 91.

Candidums, 182.

Candytuft, 46 .

Cannas, 4, 5, 14, I 5, 18, 22, 29, I IO, I2 I, I4I, I42, I45, I47, I48, I 50, I85, I87.

Allemannia, 15 .

Beds of, should be lower than the lawn, 142.

Best way of handling roots, 147 .

Black Beauty, I5.

Burbank, 15 .

Care of, I85-187.

Chicago, 15.

Florence Vaughan, I5. 
Cannas-Continued.

French and orchid-flowered varieties should be started in the house, 147.

Frozen portions should be removed, 185 .

Grow from seeds as easily, cheaply, and as soon as from bulbs, 14I.

Hints for planting and potting, 142.

Italia, I5.

Most convenient place for starting bulbs, 148.

Orchid-flowered Cannas difficult to winter, 186.

Papa, I5.

Planting in baskets, 147.

Proper soil for, 18.

Queen Charlotte, I5.

Roots to be saved should be dried in the sun, 186.

Seeds should be filed before planting, I4I.

Should be wintered in a dry cellar, 186.

Storing of tubers, 186.

Suitable soil for, 142 .

Time for sowing seed, 142.

Time for starting, 147.

Canterbury-bells, cold-frames useful to protect, 37 .

Carnation-frames, 72.

Carnation support, an easily made, 72 .

Carnations, 39, 40, 61, 70-72, $76,205,250$.

Giant of California, 70.

Growing winter plants, 72.

How to perpetuate any variety, 71.

Keeping for winter blooming and for second year, 71 .

Keeping free from insects, 72 , 73.

Layerings valuable for, $6 \mathrm{r}$.

Marguerite, 70.
Carnations-Continued.

Methods employed by florists to produce long-stemmed varieties, $7 \mathrm{I}$.

Most easily grown of all houseplants, 70 .

Planting and varieties of, 70.

Castor=oil Bean, I44. See Ricinus.

Centrosema (Butterfly Pea), I30.

Beautiful plant when in bloom, I3I.

Charming vine for north or east window, 94 .

Hard to propagate from seed, 130.

Slender growth but hardy, 132.

Transplanting and watering, I3I.

Treatment of seeds before sowing, 130,131 .

Chalcedonica Lychnis, hardy white flower, 198.

Chameleon Nasturtium, III.

Charcoal for preserving As= ters, 100.

Chicago Cannas, 15.

Chicken fences, how to make, 25 I, 252.

Chicken netting, for use in the hotbed, 37 .

Chickens should not be allowed in the garden, 251 .

Chionodoxa, I9I.

Christ and the Apostles. See Crinum Scabrum.

Chrysanthemum Flowered Aster, 99.

Chrysanthemum lice, remedy for, 248 .

Chrysanthemums, 126.

Keeping free from insects, 127.

Planting out and cultivating, 126.

Potting and boxing, 127.

Treatment of branches, I 26.

Cigar-boxes, convenient for raising fine seeds in, 48 .

Cinder walks, construction of, 9 . 
Cinerarias, $48,58,62,63,69$, 143, 208.

Care in raising in summer and winter, 69 .

Colours and varieties of, 69 .

Treatment of, for preserving through winter, $69,70$.

Clara Bedman Salvia, I21.

Clematis (Virgin's Bower), 65, 137-139, 203, 252.

Caring for and protecting in winter, 138 .

Cosmos borer destructive to, 247.

Flammula, 138, 198.

Jackmanni, 138 .

Leaves protect roots in winter, 207.

Mrs. Edward Andre, 138.

Most expensive vines to buy, 137.

Paniculata, 138.

Planting and raising, 137 .

Potting, 137 .

Raising from seed cheapest way of obtaining them, 137 .

Ramona, 138.

Trimming plants, I39.

Clothing, suitable, necessary for comfort for working in the garden, 257.

Clover-root, 65.

Coal-ash walks, construction of, 9.

Cobza San Salvador, 130.

Admirable for covering old trees, I30.

Cling to stone and brick, 130 .

Foliage of, 130 .

Manner of growth, I30.

Starting seed, $\mathrm{I} 3 \mathrm{O}$.

Cobaa scandens (Cup-and-Saucer Vine), I 29.

Desirable summer vine, 129.

Height and bloom of, 129.

Position of, in the hotbed, 35 .

Coccinea Hibiscus, 108.
Coccinea Indica, foliaged fancy gourd, 96.

Coix lachryma, 6 .

Cold-frame, the, 37,38 .

Drainage of, in winter, 38 .

For growing Gloxinias and rooting cuttings, 37 .

For sowing Pansy-seed, 37.

How made, 37.

Protection of, at night, 38 .

Useful to protect beds of tender perennials, 37 .

Coleus, $4,5,15,46,58,59,89$, $92,142,143,15 \mathrm{I}$.

Cuttings, treatment of, 59 .

Indispensable in ornamental bedding, 142.

Must not bloom, 46 .

Period of germination, 143 .

Pinching and watering, 143 .

Raised from seed, 142.

Sensitive to cold, 143 .

Suitable soil for, 143 .

Colours, harmony of, in flowerbeds, $\mathbf{I}$.

Columbine, 104, 105.

Time for sowing seed, I04.

Transplanting, I04.

Common names of flowers, 217-233.

Compost, composition of fine and rough, $5 \mathrm{I}$.

Compost heap, use for, 203.

Cope's Favourite Ageratum, II 9.

Corn Fodder, winter protection for flowers, 206.

Cosmos, 44, $\mathrm{IO}, 203$.

Cut flowers of, popularity of, 103 . Early flowering varieties only should be grown in the North, I03.

Excellent way of growing them, I04.

Fresh seed necessary every other year, 104.

How to advance their bloom, 103 
Cosmos-Continued.

Make ideal bouquets, 103.

Popularity of, I03.

Position of, in the hotbed, 35.

Cosmos borer, preventive of, 247.

Cow manure, best for the majority of plants, 23.

Crinums, $155^{-162 .}$

Americana, I61.

Blooming, time required for, 157 .

Capense, I6o.

Easily grown, 155 .

Erubescens, I6o.

Expensive luxuries, 159.

Fimbriatum, I6r.

Grandolia or Augustum, I6I.

Kirkii, 159 .

Kunthianum, I59, I62.

Lack of knowledge as to habits of, by florists, 155 .

Moorei, 160.

Must be protected from heavy rain, 159.

Ornatum, I59.

Pedunculatum, 16r.

Potting of the dry bulbs, 156.

Root-growth of, 156 .

Scabrum, I6o.

Secret of culture of, 158 .

Soil required for, 156 .

Treatment of bulb before growth, I 57.

Water, amount of, necessary, 158.

Wintering of, 159.

Criticism, adverse, hints about, 254.

Crocus, I89, 192, 193.

A pretty way to grow them, 190.

Seed formation of, 189 .

Crotons, 39, 89, 92, $15 \mathrm{r}$.

Best position for, in the sandbox, 39 .

Crown Imperials, I9I.

Cucumber, Wild, 90-96, 132, 252.
Cup-and-Saucer Vine, I29.

Cut flowers, judgment should be used in giving away, 247.

Cuttings, of common house plants, directions for handling, 58.

How to save those liable to decay, $6 \mathrm{I}$.

Lists for selection of, 58 .

Cutworms, destruction of, 203.

Cyclamen, 42, 74, 75 .

Bush Hill Pioneer, cost of seed of, 42.

Protecting from moisture and repotting, 75 .

Starting, raising, and setting out, 74.

Treatment of, in the spring, 75 .

Cyclamen Amaryllis, must not be allowed to dry out entirely, 75.

Cyperus, or Umbrella-plant, 60, 73, 74, 168.

Growing from seed an economy, 73.

Growing in jardinières, 73.

How to sow the seeds, 73 .

Raising from cuttings, 73 .

Semi-aquatic qualities of, 73 .

Two varieties of, 74 .

Cypripedium Acaule. See Japanese Iris.

Czar Peter, blue Hyacinth, 192.

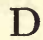

Daffodils, 256 .

Dahlias, 27, 105, 148, 149, 186, I87, 204.

Best started in baskets of sand, 148.

Borer, how to destroy, 106.

Care and protection of, for ex. hibition purposes, 106.

Cosmos borer destructive to, 247.

Easily raised from seed, 105 . 
Dahlias-Continued.

Easily wintered, I87.

For corsage wear, single varieties best, 106, 107.

Hints on grafting, 148, 149.

Planting the seed, 105.

Should be wintered in a dry cellar, $\mathbf{1} 86$.

Transplanting, and treatment after, 105.

Variety desirable for cut flowers and garden rows, 106.

Worms or beetles on, how to destroy, I06.

Daisies, 107.

Beds, suitable for borders of, 107.

Protection of, in winter, I07.

Rockwork, colours suitable for, I07.

Starting the seeds, 107.

Day Lily, 201.

Deutzia Giracilis, 198.

Dlagrams for planning a gar= den, I I-I4.

Dog-tooth Violets, I9I.

Dolichos, where to place in the hotbed, 35 .

Don'ts, a chapter of, 253-257.

Drainage, good, necessary for rendering soil light and sandy, 17.

Duck mittens, for garden work, 250.

Dusty-miller, border plants of, 8 . Dwarf Bijou Begonia, 66.

\section{E}

Earth worms, how to destroy, 249.

Eastern exposure, combination of flowers suitable for windowboxes, 92,93 .

Edgings, plants used for, ro.

Egyptian Lotus, interesting peculiarity of leaves of, 168 .
Egyptian Lotus-Continued.

Suitable for growing in small ponds, 168 .

Eight-foot flower-beds, I 6 .

Elephant's Ears, 149.

Emperor and Empress Narcissus, I9I, 192.

English names of flowers, 2 I 7-233.

Erfordii Begonia, 66.

Erianthus Ravennæ, ornamental grass, $5,16$.

Eschscholtzias, as a border for Pansy-beds, i 8.

Eulalia univittata, 5, 16.

Evergreen Amaryllis, 162.

F

Farfugium, 94.

Feathers, as fertiliser for shrubs and hardy perennials, 28 .

Fences, how to make attractive, 252.

Ferns, 23, 88, 94, 246.

Fertiliser for house-plants, 215.

Fertilisers, 23-29.

Injurious to Begonias, 217.

Necessary for Asparagus Sprengeri, 216.

Next in importance to a good soil, 23.

Filipendula, herbaceous Spiræa, I97.

Firefly Antirrhinum, for bedding, 98.

Flame Lily, 183 .

Flats, or boxes, treatment of young plants in, 50.

Floral magazines, helpful in many ways to the amateur gardener, 257.

Florence Vaughan Canna, I 5. Florists' sashes for hot-beds, 32. 


\section{Alphabetical $\mathfrak{7} \mathfrak{7} \mathfrak{d} \mathfrak{x}$}

Floss Flower. See Ageratum.

Flower-beds, arranging and marking off, 6.

General effect of growing one kind of flower in, 10.

Instructions for laying out, I4.

Instructions for making solid beds of one flower, 53 .

Water-supply for, 5 .

Width of, 7 .

Flower-pots, must not be filled to the brim with earth, 2 IO.

Flowering Maples, 63.

Flowers, common and English names of, $217-233$.

Many ways of giving pleasure with, 256 .

Necessary for a twelve-foot foliage-bed, 14.

Occasionally appearing in two or more sections, 232, 233 .

Selecting, for the sick-room, 256.

Foliage-bed, how to make a twelve-foot, I4.

Beds facing south warmer than others, 188.

Design of, 12, 13 .

Ideal bed for early bulbs, 188 .

Manuring and fertilising, 187 .

Soil of, should have good natural drainage, 187 .

Foliage plants, ornamental, from seed, I4I-I 46.

Formulas, for Bordeaux Mixture, 249.

For house-plant fertiliser, 215 .

For insecticides, 249.

For kerosene emulsion, 250.

For Paris-green solution, 250.

Foxgloves, in the cold-frame, 37.

Freesia, 40, 192, 194 .

Hints on caring for and raising, 194.

Freezing of soil in pots, no harm to plants or bulbs, 214 .

French Lilacs, 201.

Blooming season of, 201.
French Lilacs-Continued.

Planting of, 201.

Useful as backgrounds, 201 .

Fresh-air, how it should be supplied, 213.

In the living room necessary to keep insects from plants, 215.

Fritillarias, IgI.

Frosted plants, treatment for, 214.

Frozen plants, how to thaw out, 213.

How to treat, 213.

Fuchsias, 58, 88, 91, 93, 94.

Fumitory, Climbing, 129.

Funkia (Plantain Lily), or Day Lily, 201 .

Impatient of disturbance, 201.

Needs protection in winter, 201.

Suitable soil for, 201 .

\section{G}

Garden, the location and arrangement of, $3-16$.

Beds, laying out the, I3, I4.

Best position for the garden, 3 .

Fall clearing of the, 203.

Flower-beds, elevated, 5 .

Flower-beds, selection of flowers for, Io.

Foliage beds for lawns, diagram of, $10,12,14,15$.

How to prepare the flowergarden, 8.

Lawns, arrangement of, 4.

Ornamental grasses, beds of, 16 .

Ornamental plants for beds, 4 .

Parti-coloured flower-beds, arrangement of, II.

Rose-garden, design for, I2.

Scheme for permanent garden, 6.

Shrubbery, planning a, I2.

South slope, ideal situation for garden, 3 . 
Garden-Continued.

Walks, arrangement and treatment of, 9 .

Garden Spiræa, 197.

Garden-walks, marking off and measuring, 6 .

Gardener, amateur, advice to the. 20.

Geranium seeds, irregularity of growth, 78 .

Geraniums, $39,58,59,62,76-78$, 89-92, 94, 192.

Bruant, 9I.

Camphor, 9r.

Choice varieties produced by seeds from hybridised flowers, 76.

Developing of, a fascinating study, 76 .

Easy to raise, 76 .

Flourish best in the sun, $2 \mathrm{II}$.

Hints on growing, 78 .

In the sand-box, 39 .

Ivy, 78 .

Lady Washington, 76.

Most satisfactory for south or west window-boxes, $9 \mathrm{I}$.

Pelargonium, 77.

Should be grown close to glass, 77 .

Souvenir de Charles Turner, 9 I.

When to sow seed, 76 .

Zonale, 77.

German Iris, colour effects of, $198,199$.

Germination of seeds, time for, 228-232.

Giant Cassier Pansy, II6.

Cost of seed of, 4I.

Giant Crimson Antirrhinum, for bedding, 98 .

Giant of California Carnation, how to raise, pot out, and cultivate, 70 .

Giant of California Petunia, 84 .
Giant Trimardeau Pansy, 216. Cost of seed of, 4I.

Giant Welshman Narcissus, I92.

Giant White Antirrhinum, 9I, 98.

Giant White Comet Aster, 99 .

Giant Yellow Antirrhinum, for bedding, 98 .

Giant Yellow Hibiscus, 108.

Gladioli, keep well in winter stored in flour-sacks, 187.

Gladiolus, 10, 22, 25, 152, 187 .

Bulbs should be planted deeply, 152.

Childsi, 152.

Fall and winter care of, $152,153$.

Hints on planting, 152.

Improvement in culture of, 152. Rapid increase of, 152.

Reasons for planting deeply, 152 . Require frequent cultivation, 152 .

Should be planted in the full sunshine, ro.

Gladiolus=beds, ashes for fertilising, 25.

Glazing and painting old window sashes for hot beds, 32 .

Glechoma, suitable for the north side of house, 9I, 92.

Glory of the Snow, Igr.

Gloves, gardening without, ruinous to hands, $25 \mathrm{I}$.

Gloxinia-cuttings, treatment of, 60.

Gloxinias, 37, 39, 48, 58, 60-62, $78,79,151,245,246$.

An excellent place for, 245, 246.

Caring for the bulbs, 79 .

High temperature required for growing, I5I.

Hints on potting, 79 .

How seeds are sown, 78 .

How to start the plants, 151 .

In the cold-frame, 37 . 


\section{Alphabetíal 7 Jndex}

Gloxinias-Continued.

Keeping soil moist, 78 .

Mulch preferable to cultivation for, 79 .

Must be protected from heat, cold, and draughts, 78 .

Period of blooming, 79 .

Potting, 78.

Golden Glow (Rudbeckia), hardy yellow flower, 197.

Golden Saxatile Alyssum, I22.

Gourds -

Develop rapidly after making root, 133 .

Good for covering fences or unsightly buildings, 13 .

Liable to cutworms, 133 .

Ornamental feature of summer garden, 132.

Seed sown early in season, 132.

Gracillima univittata Eulalia, ornamental grass, 5 .

Grand Lilas, blue Hyacinths, 192.

Grass walks a nuisance to the gardener, 9.

Gravel walks, construction of, 9 . Green fly, remedies for, 248 .

Gruss an Teplitz Rose, 178 . Guano as a fertiliser, 28.

\section{$\mathrm{H}$}

Hammock, view of the garden from the, 4 .

Hanging=baskets-

How to water, 2 ro.

Manettia Vine very attractive for, 136.

Plants in, require more water than those on low shelves, 2 I 4.

Should be securely hung with copper wire, 209.

Thunbergias valuable for, in winter, 136 .
Hardy perennials, planting beds of, 10.

Hardy plants -

Moving and transplanting of, 196.

Setting out in Southern and Northern States, 196.

Hardy shrubs and plants for fall planting, 196 .

Harmonising of tints in arranging parti - coloured beds, II.

Heeling-in, definition of, 190.

Heliotropes, I I, 39, 59, 80, 8 \& $88,89,91,93$. II 7 .

Care of, when grown as houseplants, $8 \mathrm{I}$.

Channels should be opened in roots of, to allow water to pass in, 210.

Combined with Ageratum, effect of, $8 \mathrm{I}$.

Desirable bedding plants, $8 \mathrm{I}$.

Lemoine's seedlings exceptionally large and early, 80 .

More easily raised from seed than from cuttings, 80 .

Proper time for sowing the seed, 80.

Secret of successful growing, 80.

Should be in front of the sandbox, 39 .

Hen manure suitable for cold solls, 23.

Hepaticas, 256.

Hibiscus (Marshmallow), II, 46, 58, 103, 107-109, 203.

Africanus, hardy annual, 108.

An herbaceous perennial, ro8.

Beds of, $\mathbf{I}$.

Blooms freely if not allowed to seed, 46.

Chinese, 58.

Coccinea, a tender perennial, 108.

Cultivation of, $107,108$. 
Hibiscus-Continued.

Do not bear transplanting well, Io8.

Flowers the first season if started early, ro8.

Giant Yellow, partially hardy, I08.

Increase in size yearly, Iog.

Principal varieties of, 107.

Should be potted very hard, 58 .

Six-year clumps superb, rog.

Supports for, Iog.

Time for planting, 108.

Hickory tussock-moth, destroying cocoons of, 204 .

Hints on planting and transplanting, 54-56.

Hints on potting, 57,58 .

Hints on shifting plants, 57 .

Hollyhocks, I I, 46, IO9, I IO, 203.

Allegheny, hardy variety, IIO.

Attacks of insects on, IIO.

Beds of, II.

Planting, rog.

Require hilling up in winter, IIO.

Seed of, 46.

Sowing the seed, rog.

Suitable for effective grouping, Iog.

Honeysuckle, 6I, 252.

Layering valuable for, $6 \mathrm{I}$.

Hoof-parings, good for the perennial flower-bed, 28.

Horse manure, good in clayey soil, 23.

Horsfieldi Narcissus, I9I, I92.

House-plant raising a most fascinating work, 62 .

House-plants, a good fertiliser for, 215.

Care of, in winter, 208-2 16.

Cuttings of, easily rooted, 50 .

Directions for handling, 58 .

From seeds, $62-87$.

Hotbed, the, 30-37.

A cheap way of making a, 32 .
Hotbed-Continued.

Best position for, $3 \mathrm{I}$.

Care and attention of, 36 .

Chicken netting for use as screens in the, 37 .

Construction of pit of, 32 .

How to construct a, 3I-34.

Screens for, 36.

Treatment of plants in the, 33,34 .

Hotbeds, airing and protecting, 253.

Hotbed-sashes, cost of, 3 I.

Proper size of, 3 I.

Hot-water bath, gives better results than insecticides, 250.

Hyacinths, 38 , I70, 188 , 1890 192.

Alba superbissima, I92.

Baroness Van Thuyl, Ig2.

Czar Peter, I92.

Grand Lilas, I92.

Hints on selecting, I92.

Ida, 192.

La Grandesse, I92.

Norma gigantea, 192.

Planting, distance apart for, 188 .

Roi des Belges, I92.

Should be planted alone, I 88 .

Treatment of, and potting in the fall, I92, I93.

Use of cold-frame for, 38 .

Varieties of, I92.

Wood, 19I.

Hyacinths, Water, I 70.

Novelty of, I70.

Nuisance of, in Florida rivers, I 70.

Paris green must not be used in water, 170.

Roots increase rapidly, 170.

Hypericum Moserianum, 197.

I

Iceland Poppies, I18.

Ida, yellow Hyacinth, 192.

Impatiens sultana, 58 . 


\section{Alphabetíal $\Im$ Index}

Indian Shot, I4I.

Insecticides, 246-252.

Insects in the Rosebud, remedies for, 177 .

Instructions for raising seeds and young plants in flats or boxes, 50.

Iris, 23, 166, 197 .

Care required in raising various kinds of, 197.

Should be divided every three or four years, 199 .

Transplanting of, 196 .

Valuable for borders on drives and walks, I98.

See, also, Japanese Iris.

Italia Cannas, 15 .

Ivy, use of, for covering and protecting walls in England, I 28.

Ivy Geraniums, extra care required to keep low and stocky, 78.

\section{$\mathrm{J}$}

Jackmanni Clematis, ${ }^{2} 38$. Japan Lilies, beds of, II. Japanese Hop-

Deserves to be extensively grown, 133 .

Female plant only bears seed, I33.

Foliage very showy and effective, I33.

Pays well for care in cultivation, I33.

Requires an elastic support, I34.

Japanese Iris, best place for setting out, Io.

Has no insect pest, I99.

Moles have a liking for roots of, 199.

Wonderful colours and size of, 199.
Japanese Morning=glory, 9I, I34.

Grown in pots by Japanese, I34. Hints how to raise successfully, I34, 135 .

Requires support, I35.

Should be started in house or hotbed, I34.

Japanese Tassel Aster, 99.

June and July, shrubs and plants that bloom in, 237, 239, 240.

June Roses subject to insects, I 76 .

Justicia, 93.

$\mathrm{K}$

Kaiserin Augusta Victoria Rose, 178.

Kerosene emulsion, 250.

Kilmarnock Willow, I40. Krameri Lily, I82.

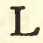

Lady-slipper. See Balsams. Lady Washington Geranium, 76.

La Girandesse Hyacinth, 192.

Lantanas, 42, 46, 8I-83, 92.

Description of, $8 \mathbf{I}$.

Make fine hedgerows, 83 .

May seed freely, 46 .

Not a desirable plant for the house, 82 .

Starting the seed, 82 .

Treatment of, in raising, $8 \mathbf{2}$.

Weeping Lantanas, 81,83 .

Will bloom freely in the house, 83.

Larkspur, excellent for rear beds, Ir.

Lavender, II.

Lawn, a neglected, amount of labour involved in a, 6 .

Layering, a form of rooting cuttings, 61 . 
Laying out flower-beds, I 3 , I4

Leaf-mould, composition of, 18 . For flower-garden, 7 .

For use in boxes, 48 .

How to make, $2 \mathrm{I}$.

Where found, 18 .

Leaves, an excellent protection to plants in the winter, 205.

Lilies, 9, II, I2, I68, I79-184, 204.

Auratum Lily bulbs, 180 .

Best time for planting, I83.

Day, 20r.

Flame, I83.

Funkia, 20I.

General treatment of all kinds of, 182 .

Hardy, planting of, 183 .

How Japanese protect their plants, 180.

Ideal spot for, 12.

Injured by exposure to air and thawings, I80, I8I.

Japanese, I8I, I82.

Krameri, I82.

Left to themselves, growth of, 183.

Longiflorum, 182.

Plantain, 201.

Washingtonianum, 182 .

Lilium album, description of, I8I.

Lilium auratum, 180 .

Lilium Brownii, 182 .

Lilium candidum, $\mathrm{r} 8 \mathrm{o}$.

Must be planted early, 180.

Soil required for, 180 .

Lilium giganteum, the most wonderful and tallest variety of Lily, I82.

Lilium rubrum, most easily grown, 181 .

Lilium speciosum, exceeding beauty of, $18 \mathrm{r}$.

Lily-bed, the hardy, 179-184. As a garden investment, 179 . Building the bed, 180.
Lily-bed-Continued.

Fibrous-rooted plants, hardy shrubs, and perennials give best results, I 79 .

Selecting a site for, I80.

Lily, Pond-

Process of germination of, 169.

Sowing the seed of, 169 .

Lily-pond-

Cementing a pond, 166,167 .

Constructing a, 165 .

Diverting a small stream for a, 166.

How to keep clear and sweet, 172.

Objections raised to, I7I.

Renewing water in, 165 .

Zinc tubs for small water-ponds, 167.

Liquid manure, how to prepare, 26,27 .

How to use, 28.

Little Dorrit Ageratum, ro2.

Loam, the best garden soil, I7.

Longiflorum Lily, 182 .

Lotus, 168.

Lotus Peliorhy nchus, 92.

Lychnis, herbaceous perennials, 198.

Semperflorens plenissima, 198 .

Lychnis Chalcedonica, I98.

M

Madame Giunther Nasturtium, III.

Manettia Vine, 93, 136.

Blooms more freely when potbound, 137.

Daily watering required, 136 .

Satisfactory for winter blooming, 136.

Time for repotting, 137 .

Manure, preparation of, for the garden, 24.

Proper use of, in the hotbed, 32. 


\section{Alphabetíal $\mathfrak{3}$ ndidx}

Manure-barrel, how to handle, $26,27$.

Manure-water, how to prepare, $25,26$.

Manures, cow, horse, hen, and sheep, 23.

Quantity necessary for use, 29.

Maples, flowering, 63 .

Marguerite Carnations, best for outdoor blooming, 70 .

Marshmallow. See Hibiscus.

Maurandya, 46, 9o, 9r, 93, 135, 246.

A beautiful vine for window. boxes, 90.

Height of plant and colours of flowers, 135 .

Requires no special treatment, 135 .

Seed of, gathered without harm to vine, 46.

Suitable for trellises, window. boxes, and vases, 135 .

Time for sowing seed, 135 .

May, trees, shrubs, and plants that bloom in, 235, 236.

Mealy bug, remedy for the, or house-plants, 248.

Metake Bambusa, I7I.

Milk-and-Wine Lily, r6r. See also Crinum fimbriatum.

Miranda Petunia, 84 .

Mixed seeds, variety of, 62 .

Molsture-loving plants, best place for setting out, Io.

Moles, liking of, for roots of Japanese Iris, 199.

Netting and traps for, r99.

Monkshood, Ir, 46, r22.

Excellent for rear beds, Ir.

Montbretias-

Desirable for cut flowers, 153 .

Keep well through winter in flour sacks, 187 .

May be grown in corners of flower-bed, 153.

Multiply rapidly, 153 .
Montbretias-Continued.

Resemble Gladioli in flower and foliage, $\mathrm{r} 53$.

Moonlight Nasturtium, III.

Morning-Glories, 42, 44, 46, 9I, 94, 252, 256.

Reaching the roof by strings, 94.

Require little root room, 94 .

Seed of, 46.

See also Japanese MorningGlories.

Mountain Fringe, 129.

Mrs. Edward Andre Clematis, 138.

Mrs. Robert Perry Rose, 178. Muck or peat, preparation of, 18, 19.

Myosotis, IIg.

\section{$\mathrm{N}$}

Narcissi, 38, 188, 191, 192.

Alba plena, II9.

All species are hardy, IgI.

Emperor and Empress, I91, 192.

Giant Welshman, 192.

Horsfieldi, 191, 192.

Odoratus, 191 .

Paper white, 192.

Planting of various varieties of, xgo.

Poeticus, r9I.

Treatment of, and potting in the fall, 192, I93.

Trumpet varieties of, 192.

Use of cold-frame for, 38 .

Varieties of, I9r, 192.

Von Sion, 191, 192.

Nasturtiums, 15, 45, 92, 94, 96, I IO, III, 252.

Chameleon, new variety, III.

Dwarf varieties very attractive for Canna-beds, I ro.

Flourish well in elevated beds, III. 
Nasturtiums-Continued.

Grown on strings and trellises, III.

Madame Gunther, mixed variety,

III.

Make excellent edges for beds, I5.

Moonlight, pale cream variety, III.

Require abundant root room, 94 . Saving seed of, 45 .

Sunlight, new variety, III.

Tall varieties make effective beds, III.

Trailers, not climbers, IIr.

Will not bloom well in shade, IIo.

Nicotianas, how to sow, 35 .

Nine-foot flower-beds, 15 .

Niobe Antirrhinum, for bedding, 98 .

Norma gigantea Hyacinth, 192.

Northern exposure, combination of flowers suitable for window-boxes, 93, 94.

Nymphreas, 168-170

Hardy, for planting in soil of Lily-pond, 168.

Varieties of, suitable for amateur cultivation, I69.

\section{O}

Odds and ends, chapter of, 245252.

Odoratus Narcissus, 19r.

Orchid-flowered Cannas, treatment of, in winter, 186.

Oriental Popples, r18.

Ornamental foliage plants, beds of, 4 .

From seeds, 141-146.

Ornamental grasses, 5 .

Nine-foot bed of, 16 .

On lawns recommended, 16.

Ornithogalum arabicum, 192.

Requires high temperature, I94.
Ostrich Feather Aster, 99.

Otaheite Orange, 58 .

Oxalis, Summer-blooming -

Advantage of precocity of growth, 154 .

Bermuda, 195.

Desirable for borders, 154 .

Extensively grown in parks and public gardens, 154 .

Good substitute for other plants that have failed to come up, I54.

Hints on raising, 195.

How to buy and set, 154 .

Most easily raised of all bulbous plants, 154 .

Rapid growth of, 154.

\section{$\mathbf{P}$}

Pronia. See Peony.

Pansies, 10, 18, 23, 25, 34, 37, $4 \mathrm{I}, 44,53,67,8 \mathrm{I}, 84,85$, I12I18, 205, 206, 253.

Aurora, I16.

Best place for planting, ro.

Cold weather, care of, during, II2, II3.

Daily care of, 253.

Fungoid disease and mildew, remedy for, II5.

Germination, period of, II2.

Giant Cassier, Ir6.

Giant Trimardeau, 216.

How to carry Pansy bed through winter, II6, II7.

How to raise sturdy plants, II2.

In the cold-frame, 37 .

Planting, best place for, 115 .

Seeds, fresh, every year for best varieties, II6.

Snow Queen, II6.

Soot as a fertiliser for, 25 .

Sowing in cold-frame or hotbed, II2.

Special mixtures of seeds, Ir6. 


\section{Alphahetíal $\mathfrak{J}$ ndex}

Pansies-Continued.

Spring, treatment of roots in the, II3.

Time for sowing seed, 112.

Transplanting, Ir3.

Watering beds of, II4

Pansy-bed, the, rr2-IIg.

Proper soil for, 18 .

Pansy-seed-

Should be grown by a specialist, 44.

The best is the cheapest, 41 .

Papa Canna, I5.

Paper White Narcissus, 192.

Paris green, 100, 170, 172,177 , $247,249$.

Paris green solution, 250 .

Parti-coloured beds of flowers, arrangement of, II.

Pelargonium Geraniums-

Cuttings of, for new plants, 77 .

Time for blooming, 77.

Very satisfactory when raised from seed, 77.

Pennisetum Ruppellianum, I6.

Peonies, 9, II, I79, 200, 20I, 204, 206.

Best soil and location for, 200.

Raised beds of, II.

Peony Aster, 99.

Peony-beds, should be heavily mulched with manure in the fall, 20 I.

Perennial-beds, must be well rounded up, 204.

Perennials, benefited by removal of withered flowers, 46.

Hardy, grouping of, in flowerbeds, 10.

Perfection Aster, 99.

Perpetuals, hardy, 176.

Petunias, 9, 35, 42, 45, 58, 83$85,93,96$, II 7 .

Bloom freely in the house, 85 .

Burpee's Defiance, 84 .
Petunias-Continued.

Double variety more suitable for pots, vases, and bedding out, 84.

Giant of California, 84.

Growing plants of, from seed, 45 .

How to distinguish the finer varieties, 85 .

How to sow seed of, 35 .

Improvement in growth of, the last few years, 83 .

Instructions for raising, 84 .

Miranda, 84.

Poor or inferior plants should be removed, 85.

Potting and caring for, 85 .

Young plants require great care, 84.

Phacelia, 96.

Phlox Drummondi, II, 16,42 , 9r, 96, Irg.

Beds of, $I r$.

Border of dwarf variety, II9.

Germination of seed, I Ig.

Phiox subulata, border plants of, 8 .

Pinks, grow best from self-sown seed, 45 .

Plant enemies, increase of, 246 , 247.

Plant growing, failures in, 58.

Plant fice, or green fly, remedies for, 248.

Plantain Lily, 20r.

Planting seed, 34-36.

Plants-

Blooming season of various, 234-244.

For winter blooming should not be exposed to chilly nights, 208.

How to treat when frozen, 213.

Learning to keep, 254.

Method of shifting and bedding out, $5 \mathrm{x}$.

Need room to develop, 253. 
Plants-Continued.

No more should be raised than there is room for, 253.

Proper breathing of, 2Ir.

Protecting from cold and sun, 204, 205.

Protection for tall ones, 206.

Received by mail, treatment of, before being put in windowboxes, 95 .

Saving seed and giving away cuttings, 254 .

Should have room to breathe and grow, 208.

Sudden change of temperature should be avoided, 2 I 2 .

Support should be given to such as need it, 212.

Transplantation of, in the fall, I96.

Treatment of, for winter bloom. ing, $5 \mathrm{x}$.

Wintering of, 196.

Poa, an edible food of the Sand. wich Islands, I49.

Pond Lily, I69.

Poeticus Narcissus, Igr.

Poeticus ornatus Narcissus, I9I.

Polyanthus, I9I.

Poppies, 44, II7-II9, I70.

Hunnemannia fumariæfolia, II8.

Iceland, II 8.

Oriental, 118.

Shirley, II7.

Should not be grown too closely, II8.

Value of seed from, 44.

Poppies, Water, 170, I7I.

Attractiveness of, $\mathrm{I} 7 \mathrm{I}$.

Poppy-seed, sowing in the Pansy-bed, II 7.

Porches, Thunbergias valuable for covering foundations of, 136.

Pot-bound plants, hov to remove, 57 .
Potting, hints on, 57,58 .

Potting-soil, always keep ready for use, 40 .

How to obtain, 2 I.

Primroses, 63, 86, 87, 246.

Blooming time, 86.

General treatment of, 86 .

Potting, 86.

Primula obconica grown in shallow dishes, 87 .

Raising from seed, 87 .

Receptacles for, 86.

Repeated shifting aids blooming, 86.

Root room necessary, 86 .

Primula obconica, 87 .

Primulas, 48, 58 .

Princess Caroline Ageratum, IOI, ro2.<smiles>O</smiles>

Queen Charlotte Cannas, I5. Queen of the North Antirrhinum, 98 .

\section{$\mathrm{R}$}

Radicans Blgnonia, I39, I40.

Ragged Robin (Viscaria), red, scented flower, 198 .

Ramona Clematis, 138 .

Red Spider, remedy for, 248.

Repotting, meaning of term, 56 .

Repotting house-plants in summer, 40 .

Rex Begonia, 66.

Rhododendrons, protection of, in Northern winters, 206.

Ricinus (Castor-oil Plant), 4, 5, $14,15,18,29,35,46,12 \mathrm{I}$, I44, $150,200$.

Beds of, 5 .

Good background for low shrubs, I44. 


\section{Alphabetical $\Im \mathfrak{I n d e x}$}

\section{Ricinus-Continued.}

In flower-beds, I4, I5.

Most tropical looking plant in cultivation, I44.

Position of, in the hotbed, 35 .

Proper soil for, 18.

Seed of, 46 .

Seeds should be started in house pots, I44.

Soil must be heavily manured and well watered, I44.

Transplanting, I44.

Zanzibar varieties best, I44.

Rockwork, Thunbergias valuable for covering, I36.

Roi des Belges, a red Hyacinth, Ig2.

Rose, the, need of constant care of, 247 .

Rose-bed, care of the Summer, 173-178.

Choice of plants for the, 178 .

Cutting and pruning, 175, 176.

Hardy Perpetuals, caring for, 176.

Insect enemies of Roses, I76, 177 .

Manuring, I75.

Planting the bed, I75.

Soil suitable for, $\mathrm{I} 75$.

Sunny, protected situation neces. sary, 175 .

Treatment of Roses that refuse to bloom, 176 .

Rose-bug, destruction of, 249 .

Rose-bugs and beetles, remedy for, 177 .

Rose Campion (Lychnis), herbaceous perennial, 198.

Rose-cuttings, handling of, 59 .

Rose-garden, design for, $12,13$.

Rose-hopper or thrips, on Rose leaves, remedy for, $177,248$.

Rose of Sharon (Althea) -

Method of blooming, 202.

Winter care of young and old trees, 202.
Rose-slugs, how to get rid of, I77, 248.

Rose, June, I73, I74.

Cultivation and pruning of, 173 , I74.

Hardy climbers, treatment of, I74.

Insects, a pest to, 176 .

Labor of caring for, objectionable to some, 173 .

Mulching in the fall, I74.

New wood should be encouraged, I74.

Thorniness of, 173 .

Winter protection of, $\mathbf{1 7 4}$.

Rose, Tea, I74, I75.

Excellent for summer Rose-bed, I74.

Insects, generally free from, I 76.

Mildew, how to avoid and rem. edy for, I77.

Potting, I75.

Transplanting into open ground, 175.

Roses, 3, I7, I8, 23, 25, 27, $37,39,58,59,6$ I, I73-178, 252.

American Beauty, I78.

Bride, 178.

Climbing, winter protection of, 204.

Gruss an Teplitz, I78.

Ka1serin Augusta Victoria, I78.

Kept in house in winter, how to keep free from pests and in. sects, I78.

Mrs. Robert Perry, I78.

North winds disastrous to, 3 .

Proper soil for, I7.

Soot a good fertiliser for, 25 .

Virginia R. Coxe, I78.

Rubber gloves for garden work, 250.

Rubber-plants; rooting and care of, 60 . 
Rubber sprinklers, indispens. able for watering hangingbaskets, 214

Rudbeckia, 197.

Ruffled Giant Petunia, 84 .

S

S. A. Nutt Geranium, for south and west window-boxes, $9 \mathrm{I}$.

St. John's Wort (Hypericum Moserainum), a perennial, 197.

Salt pork, for keeping moles from Iris roots, 200.

Salvia (Flowering Sage), 5, I4, I5, I8, 29, 46, 120.

Bonfire, I2I.

Clara Bedman, I2I.

Desirable for bedding purposes, I20.

Do well in partial shade, I20.

Most congenial soil, 120 .

Root readily in wet sand, $\mathbf{I 2 r}$.

Scarlet, 14, I5.

Seed germination, I2I.

Splendens, 5, I2I.

Subject to red spider in the house, 120.

When to start seed, 120.

White-flowered variety, I2I.

\section{Salvia patens, $12 \mathrm{r}$.}

Seldom seen in gardens, 122.

Wonderful blue shade of, 122 .

\section{Salvias-}

Proper soil for, I8.

Seed freely, 46.

San Salvador Cobæa, Iзо.

Sand, white or grey, best for potting, 2I.

Sand-box, the, 38-40.

A fascinating spot, 39 .

How to make one, 38 .

Summer storage of plants in, 38 .

Saxatile, golden, I 22.

Desirable for edging or rockwork, I22.
Scilla, I89, I90, 192, 193.

Scillas and Crocuses-

A pretty way to grow, 190.

Beds of, 189.

Lengthening of flower-stems, rgo.

Protection of, I89.

Screens for the hotbed,

36.

Scythe-boxes makegood window-boxes, 94 .

Seed, various annuals from, $98-$ III.

Seedlings, blossom in the natural course, 62.

Seed-planting, 34-36.

Seeds, coarse varieties, how to sow, 49.

Fine varieties should be sown broadcast, 49 .

House treatment of some fine varieties, 48.

Labelling and storing, 47.

Need little light while germinat. ing, 49.

Protection of, in their early stages, $3^{\circ}$.

Purchasing of, 4I-47.

Should be gathered when ripe. 47.

Starting in flats, 48-52.

Temperature and period of ger. mination, 32.

Time for germination of, 228232.

Uselessness of buying cheap va. rieties of, 42 .

Vitality of some kinds of, 42.

What kinds to save, 43,44 .

Where to buy, 42 .

Where to plant coarse, 35 .

September, shrubs, plants, and bulbs that bloom during, 242, 243.

Seteria magnia, 16.

Shade-loving plants, an excellent place for, $245,246$. 
Sheep manure, desirable for house-plants, 23.

Shell Flowers, I53.

Shelves for flowers in winter, 208.

Should be securely fastened, 209.

Shelter, proper, for flowers, 3 .

"Shifting," meaning of term, 56.

Shirley Poppies in the Pansy bed, II 7 .

Shrubbery, planning a, 12.

Shrubs, blooming season of, 234244.

Spring-planted, should be moved when dormant, I96, 197.

Shrubs and plants, hardy, for fall planting, I96.

Sir Watkin Narcissus, or Giant Welshman, I9I, I92.

Skirts, suitable, for working in the garden, 257.

Slop-water should not be used for foliage plants, 27.

Snapdragon. See Antirrhinums. Snow Queen Pansy, i 6.

Cost of seed of, 42 .

Snowdrops, a pretty way to grow, 190, I9I.

Soapsuds a good fertiliser, 27.

Sod, preparing garden, 8.

Sod borders, involve too much care in flower-beds, 9.

Soil, preparation of, for the flower-garden, 7.

Replacing, difficulties of, 20.

Unsuitable, cause of many failures in raising plants, I9.

Soils, I7-22.

Solanum Jasminoides, 93.

Soot as a fertiliser for flow = ers, 25.

South slope, the ideal situation for a garden, 3 .
Southern exposure, combination of flowers suitable for window-boxes, 91, 92.

Souvenir de Charles Turner Geranium, 91.

Spade, results secured by use of, in making flower-beds, 7 .

Spading flower-beds, 8 .

Speciosum Lilies, exceeding beauty of, I $8 \mathrm{I}$.

Speciosum roseum Lily, I8r. Speciosum rubrum Lily, $18 \mathrm{r}$. Sphagnum moss, for wrapping Rubber-plants' roots in, 60.

Spiraa filipendula, 198 .

Spiraea Japonica, I98.

Spiraas-

Anthony Waterer, 197.

Desirable for fall or spring planting, 196.

Filipendula, I97.

Garden, I97.

Mealy bug on, 248 .

Van de Houttei, 197.

Spring, treatment of toots and seeds in the, II3. I96.

Spring-planted shrubs, I 96.

Stakes for house - plants, 40.

Stocking window-boxes, 95 .

Subsoil, removing for flowerbeds, 7 .

Sulpho-tobacco soap, a remedy for plant lice, 248 .

Sulphur, for mildew on Pansies, I 5 .

Flower of, for dusting over roseleaves to prevent mildew, I77.

Summer, shrubs, plants and vines that bloom all the, $\mathbf{2 4 3}$, 244.

Sunflower, California, I97.

Sunlight Nasturtium, III.

Sun-loving plants, care of $2 I I$. 
Supports for window-boxes, how to make, 94, 95.

Surface-soil, treatment of, for flower-beds, 7 .

Swanley Blue Ageratum, 102. Sweet Alyssum, 5, 9, I4, 46, $96,121,122$.

Little Gem, edging for flowerbeds, 5,14 .

Sows its own seed, 46.

Sweet=peas, 46, 122-124, 252, 253.

Bewildering variety of, 124 .

Culture of, 122.

Daily care of, 253.

Habit of climbing, 123.

Must not be permitted to seed, 46.

Planting, 122.

Sowing seed of, best time for, 122.

Watering, method of, 123.

Wire supports necessary for growth, 123 .

\section{T}

Tea-roses, 37.

Freer from insects than June Roses, 176.

In the cold-frame, 37 .

Temperature, a sudden change of, should be avoided with flowers, 212.

Thawing out frozen plants, 213.

Thermometer, necessary for the hotbed, 35 .

Thunbergia (Black-eyed Susan), $46,47,90,92,93,136$.

Admirable for basket or bracket plants in winter, 136 .

Grow freely from seed, 136 .

Red spider attacks, 136 .

Requires sunny situation, 136 .

Seed may be gathered from, 46 .
Thunbergia-Continued.

Valuable for covering low trel. lises, 136 .

Tigridias, beautiful in colour, 153 .

Ephemeral flowers of, 153 .

Peculiar leaf of, I53, I54.

Potting and bedding out, 153 .

Tobacco, use of, for killing plant. lice, 248.

Tom Thumb Ageratum, desirable for edgings, IOI.

Tools necessary for the successful gardener, 245 .

Top-soil, removal of, in making flower-beds, 7.

Transplanting, instructions for, 54 .

Seedlings, 50.

The proper time for, 54 .

Transplanting and repotting, 53.

Trailing Fuchsia, 9I.

Trapping moles in Iris-beds, 200.

Trees, blooming season of, 234244.

Trellises, Thunbergias valuable for covering, 136 .

Trumpet Vine, I 39 .

Tuberoses, do well in Gladiola. bed, I64.

Double Pearl, blooms but once, 163,164 .

Must be started in a warm place, I63.

Plenty of water required, $\mathrm{I}_{3}$.

Potting, 163 .

Tulips, 188, 189, 193.

Neglected beds of, 189 .

Planting, distance and depth for, I 88.

Plants of same height and season should be set together, 189 .

Storing away, 189 .

Twelve-foot flower-beds, I4, I5. 


\section{U}

Umbrella-plants, $60,73,74$, 168.

How to start root, 60.

Unsuitable soil, cause of many failures in raising plants, 19 .

Urns, Thunbergias valuable for, 136.

\section{V}

Van Houttei, white Spiræa, 197.

Verbenas, 44, 45, 92, 96, 124127.

Colours should be kept separate, 124.

Enjoy rock-work, 125 .

Thrive in any good soil, I25.

Treatment of seed before plant. ing, I24.

Vernon Begonia, 66.

Vincas (Periwinkles), 15, 16, 46, 94, 125.

As border for Canna-bed, 125.

Bloom more freely if not allowed to seed, 46 .

Foliage and flowers, colour and texture of, 125 .

Moisture, fair amount of, necessary, 126.

White-flowered, 15, 16.

Worthy extensive cultivation, 125.

Vines, $128-140$.

Prejudice against, $\mathbf{1 2 8 .}$

Time for planting, 53 .

Training of, over sides of the sand-box, 39.

Walls indestructible when covered with, I28.

Violets, 23, 37 .

Dog-tooth, 19r.

Protection of cold-frame for, 37 , 38.

Virginia Creeper, 128.

Virginia R. Coxe Rose, I78.
Virgin's Bower, 137 .

Viscaria (Ragged Robin), a scented garden flower, 198.

Von Sion Narcissus, 19I, 192.

Vulcan Begonia, 66.

\section{W}

Walks, garden, construction of, 9.

Washingtonianum Lily, 182.

Water gardens, 104.

Water Hyacinths, I 70 .

Water, standing, injures roots of all plants, 204.

Water-supply for elevated bed, 5 .

Watering seeds in flats, 50.

Watering soil in boxes, 49.

Watering-pot, should not be used in sowing seed, 36 .

Weeping Lantana, 81, 83. See, also, Lantana.

White, the most valuable colour in the garden, II.

Wild Cucumber, $90,91,93,96$, I32, 252.

A beautiful background for $\mathrm{Ge}$ raniums in the window-box, 90.

Willow, Kilmarnock, I40.

Window-boxes, inside, best support for, 94 .

Cheap and available boxes, 95, 96.

Combination of plants suitable for a southern exposure, $9 \mathrm{r}$, 92 ; for eastern exposure, 92, 93 ; for northern exposure, 93 , 94 .

Economical arrangement of, 96 .

Geraniums best for south or west boxes, 91 .

How to care for and raise flow. ers in, 97.

Longevity of, 96 . 
Window-boxes-Continued.

Plants in, require watering every day, 253.

Preserving during winter, 95 .

Quantity of plants necessary for, 89, 90.

Stocking, 95 .

Two boxes necessary for the season, 90 .

Window-boxes, outside, 8897.

Add to cheerfulness of rooms, 88.

Plants best suited to the light should be selected for, 88 .

Proper construction of, 89.

Suitable plants for, 88.

Supply of water necessary, 89 .

Window-sashes, old, for use in making hotbeds, 32 .

Winter Aconite, I9I.
Winter, care of old and young trees in the, 202.

Winter protection of flowers and shrubs, 203-207.

Wire netting, judicious use of, in the flower garden, $25 \mathrm{I}$.

For Moles, 199.

Wood Hyacinths, I9r.

Wooden frames, best results from, as winter protectors, 203.

Work-table, indispensable in cultivating a garden, 39 .

Worthless seeds, 42.

Z

Zanzibar varieties of Ricinus, best for cultivation, I44.

Zonale Geraniums, time for blooming, 77.

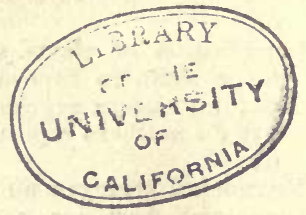





THIS BOOK IS DUE ON TIE IAST DATE

RETURN CIRCULATION DEPARTMENT

IO $\longrightarrow 202$ Main Library

LOAN PERIOD 1

HOME USE

4

5

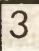

4

ALL BOOKS MAY BE RECALLED AFTER 7 DAYS

Renewals and Recharges may be made 4 days prior to the due date.

Books may be Renewed by calling $\quad 642-3405$

\section{DUE AS STAMPED BELOW}

\section{DEC 091992}

AUTO DISC CIRC MA $13^{\prime} 93$

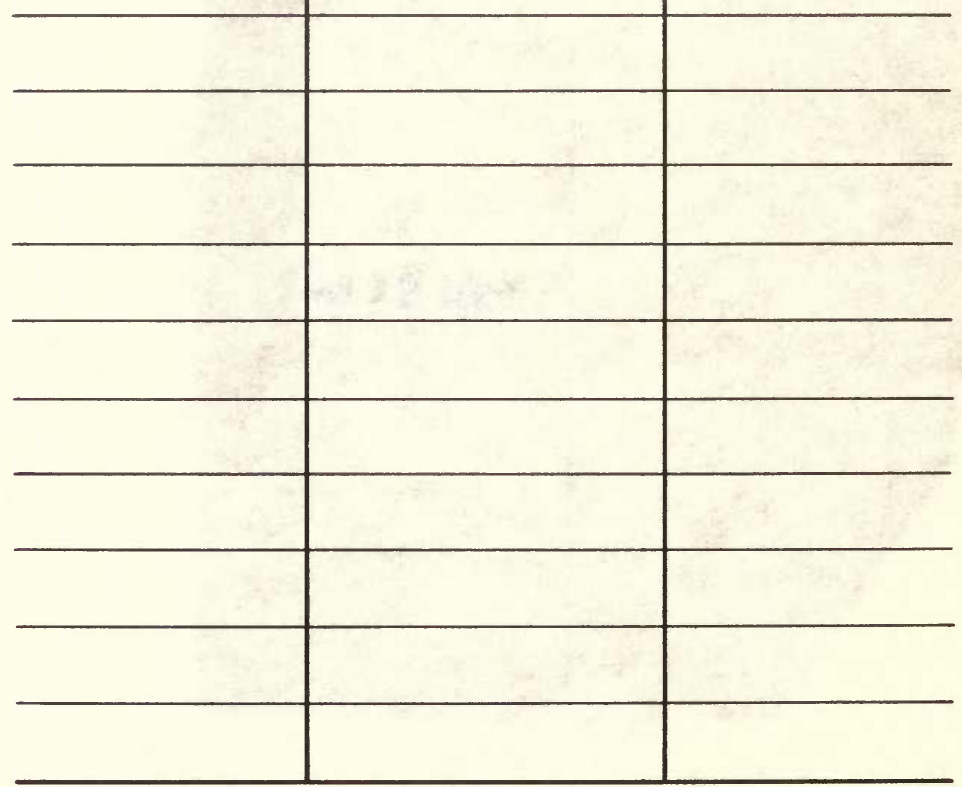

UNIVERSITY OF CALIFORNIA, BERKELEY

FORM NO. DD6 BERKELEY, CA 94720 
Sien a
110 ker

\section{YB 48532}

U. C. BERKELEY LIBRARIES

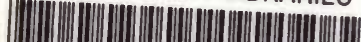

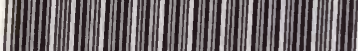

C041,442423

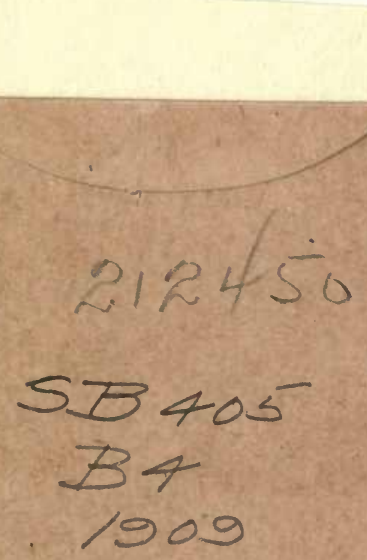

UNIVERSITY OF CALIFORNIA LIBRARY. 
